\section{ILIINOIS}

\section{Fistory Survey BULLETIN}

\title{
The Diptera, or True Flies, of Illinois I. Tabanidae
}

THE LIBRARY OF THE

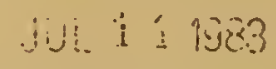

UNIVERSITY OF ILLINOIS AT URPANIA_R LAMPAIFN

DEPARTMENT OF ENERGY AND NATURAL RESOURCES

NATURAL HISTORY SURVEY DIVISION CHAMPAIGN, ILLINOIS 



\section{ILIINOIS}

atural Fistory Survey

\section{BULIETIN}

\section{The Diptera, or True Flies, of Illinois I. Tabanidae}

L. L. Pechuman

Donald W. Webb

H. J. Teskey

NATURAL HISTORY SURVEY DIVISION CHAMPAIGN, ILLINOIS 


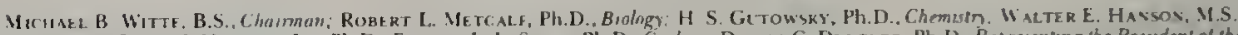

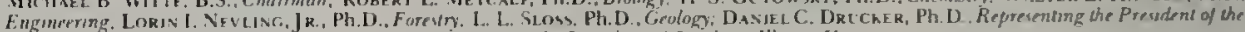

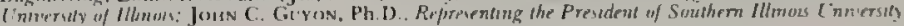

\section{NATURAL HISTORY SURVEY DIVISION, Champaign, Illinois SCIENTIFIC AND TECHNICAL STAFF}

Pacte G Rissek, Ph.D., Chief

Alict K. ADAMs. Secretan to the Chuef

\section{Section of Aquetle Blology}

Rogtri W. Gorden, Ph.D., Aquate Bulogst and Head D. Homiz Bl'Ck, Ph.D., Aqualte Biologzst R. WELDON LARINORE, Ph.D., Aquatic Buologzs? Richakd E. Sparks, Ph.D., Aqualic Bulogest Allison R. Bricham. Ph. D.. Assoczale Aquapte Buologzst David P. Phil.tPp. Ph D., Associate Aquatoc Biologut Ketloah Reinbotd, Ph.D., Associale Aquatic Toxicologzt William Sieiner. Ph. D., Assoczate Aquatic Biologut

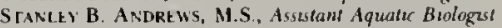
Peter B. Bastey. Ph D., Assistant Aqualie Btologut Kenneth S. Ll'BiNshi, Ph D. Assestant Aquatic Bulogst TeD W. STrorck, Ph.D.. Assatant Aquate Biologzst Michael J WILEY. Ph. D. Asszitani Aquaic Biologzst JANa L. Waite, M.S., Assesiant Supporive Screntest Jens D. SANDBERCER, M.S., Jumor Professional Scienist Fígene Sons, Junot Professional Sctentest PAM Tazik, MIS., Junior Professional Scuentzse Min.Sil Hilang. Ph.D.. Research Assockate Thonas Skelly, M.S., Research Assoctale Stephen W. Waite. M.S., Research Assorult ROBER D Davis, M.S., Specialst in Aquatse Brolog? BiLl. Dimond, B.S., Speralest in Aquatic Brology Scott D. JACkson, M.S., Spectalest in Aquatte Biology Steven MILLeR, B.S., Specialat in Aquatic Biology STEPHANIE SWEciker, B.S., Speculese in Aquatic Riolon Dolcilas K. Blodee TT, M.S., Research Assustant BRIAN C. HaMipSON. B.S., Reseatch Assetianl Richard E. HaZzard, B.S. Research Assistant Michatt. HoOt, B.S., Research Assestant JEFFRE KOPPELMAN, B.S., Research Assulant Phil. C. MANkin, B.S., Research Asststant Dennis Newman, M.S., Research Assustani LANCE PERRY, M.S. Research Assestant Steve Pescitelli. M.S., Research Assuskini TODo Powless, M.S., Research Assistant Gary L. Warren, B.S., Reseatch Assustant JOAN Brower, B.S., Technical Assetsant JOHN EPIFANio, B.S., Technucal Assistam KATHARYN L. FU'ING; B.S., Technical Assisfant TOM KWAk, B.S., Technical Assutant Shirley Lowe, B.S. Technical Assestant Si'e Peratt, Technical Assitant Kanf ROAT, Techricnl Assistant STEPHEN SUBASKL!, B.S., Technical Asswhtant Jeffrey van Orman, B.S., Techrical Assestant RUTH M WAGNER, Junor Techrical Assstan!

\section{Sectlon of Botany and Plant Pathology}

Claces Grenwalo. Ph.D., Botarsist and Head

I. Leland Grane, Ph.D. Mrycologzit

Eligene Himelick, Ph.D. Plant Pathologat

Dan Nefly, Ph.D., Plant Pathologzst

D. E SChotnewelss, Ph.D., Plant Pahologlat

Antun G. Endress, Ph.D., Associate Botantst

KENNETH R. RoberTSON, Ph.D. Assoctate Botoms

LOL'1s R. IVERSON, Ph.D. Assestant Botanest

MAKY DEIster. Asszstani Biologes

RoBerta Steward, Asststrut Biologut

BETTY NELSON, Assestant Supporture Scientst

James E. Sercient, Greenhouse Superiniendent

Steve CIINE, Ph.D., Research Assiglant

Robert A. Harrison. Techmzal Asszstant

DAvid R. MOORE, B.S. Technical Assistant

LAL'REL MCKFt, Revarch Asststant

JOHN M. MLPARTLAND, Resparch As.szsant

Robin C. Moran. Research Assstumt

JaMES A STIM, Rrsearch Arrstint

Diane Szafoni, B.S., Rescarch Alsistam

\section{sectlon of Economle Entomology}

William H. Leckmarx. Ph.D. Entomologrs and Head J AMks E. APPlebr. Ph.D., Entomologut EDWard ]. Armbrist, Ph.D., Entomologzst Aarcos Kogan, Ph.D., Entomologzs Donato E Klylmas, Ph.D., Eniomologrst, Eximsion JOSE.PH V. MADDOX. Ph.D., Entomologzs? SIEVensox MoORe, III. Ph.D., Eniomologzst, Exiension Roscoe Randell. Ph.D. Entomologut, Extension Catherint E. Eastmas, Ph.D., Assoriale Entomologut AlLAN S. FELSOT, Ph.D., Assorzate Entomologut Michafi E I Rwis, Ph. D. Assorate Entomologzse W'ILIAM G. RL'siNk. Ph D. Associale Entomalogus JoHs K. BoLsenas, M.S., Assustame Entonologast Clatis Colwell, M.S. Assitane Entamologzs, Exicrision Michafi JefFords, Ph.D., Assistand Ensomologst Eli LEvive, Ph.D. Asustant Entomologwt Charies MacMonegle, M.S.. Assustand Entamologust, Eximsion KEVIN STEFFEY, Ph.D., Assistans Ertomologust, Exiension Le'IS R. Zasileta, Ph.D., Assestant Entomologut StEPHEN P. BRIGCS, M.S. Acsistant Specialsst, Extmston David Swofford, Ph.D., Bumeincian/Statusticlan Lester Wei, Ph.D., Asszstant Professional Scienilut John T. Shaw. B.S. Assoctate Supportuve Scienist JEAN G. WiESON, B.A.. Assoczale Supportive Scientaif Charces G. Helm. M.S. Assistant Supportize Sctonizs Stephen J. ROBERTS. B.A. Asslitani Supportine Sicuntast Jo ANn Ai bLe, Juntor Professional Scienizst JenNy Kogan, M.S. Research Associale William O. LAmp, Ph.D., Resparch .Assorate KAREN O'H A)ER, Research tsrociale

Brenda M. Peters, Research Assocuate CharLes GL'SE, B.S. Research Assustant Dosle Dazes. Field Eniomologus CRAIG D REID, Field Assistani

LAL RIt CASE, Research Technican

Tzl-Sian Cht: M.S., Researeh Technician Gail Kanpueier, M.S.. Research Technotar GeR.aLd LEPAR, Research Technician

Muchafi McGi'jRe. M.S., Research Technurzan Marilia MORRIS, Research Technician S.ARA MreRs, Research Techniclan SISAN POST, Research Techmician Ellen Brewer. M.S., Compulet Progtammer Frank M. Broukfield M.S. Computer Programmer Dorothea Grider. Transcombing Sectetan; Exienswor SANnRa MC:G.ARY, Clekk-Typust III Joan Tral'b, Clerk-Typast III

MARY COLNCIL, Clrk-Typust II

Diare ERDMaN: Cletk-Typlat II

WEIRO C.HEN, B.S, lisiting Scuentast

MIRE Foster, M.S., Graduan Tearhing Acsizan JOEL SIEGEL, M.S., Graduale Reserath . Aswiant

LANe Smith, M S., Gradwate Reverch Asuztani

section of Faunistic Surveys and Insect Identification

LAWrence M. PAcie, Ph.D., Fish Taxonomusl and Achng llead Wale cie E. LaBerge. Ph. D., Insed Taxonomut Warkex U. Brichas. Ph.D., Insed Taxnomas DONALD W: W'EBB, Ph.D., Inser Tavonomls Georce L. GoDfrei. Ph.D. Assiczale I meet Taxonomst JOHs D. L'zicker. Ph.D. Assockatr insed Tizanomis

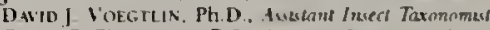
Colin G. Trewortiy, B.S., Alsomale Suppormar Sormpas Bernice. P. Sweenel, Austant Suppartive Scicutas?

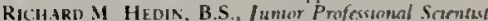
STEUEN IJEYTMN. M.S., Research A tristant El'Cenf R. MItic:zh), M.S. Resmarch Asststant MATTHEW K. Bi-TCHER, MI.S. Technoal A ssistant 


\section{CONTENTS}

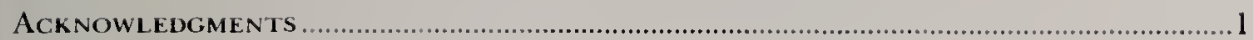

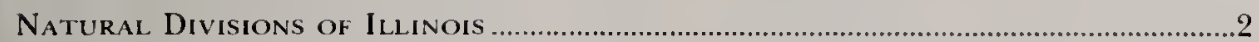

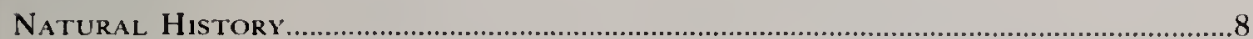

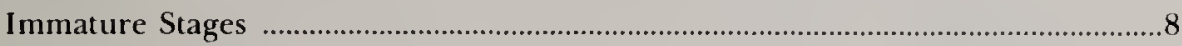

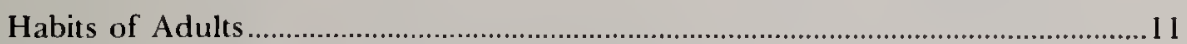

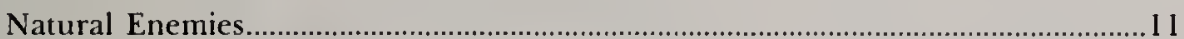

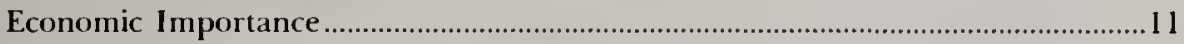

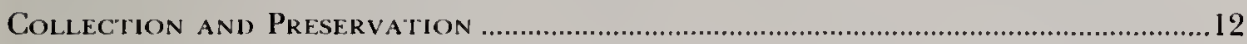

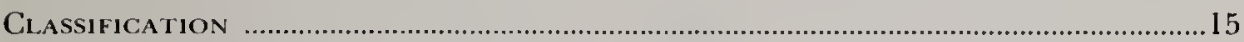

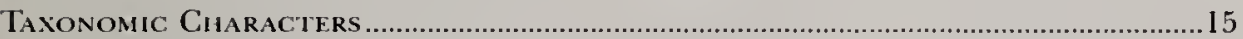

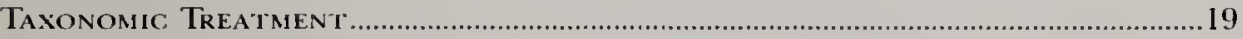

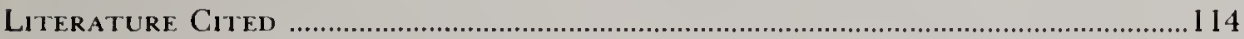

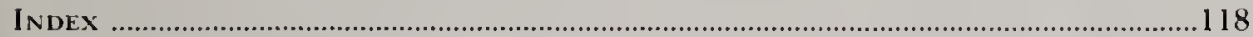

This report is published by authority of the State of Illinois. It is a contributnon from the Section of Faunistic Surveys and Insed Identification of the Illinous Natural History Survey. Dr. L. L. Pechuman is Professor Emeritus, Department of Entomology, Comell University; Dr. Donald W. Webb is a Taxonomest, Section of Faunistic Surveys and Insed Identification, Illinois Natural IIston Survey; and Dr. H. J. Teskey is in the Diptera Section, Biosystematics Research Institute, Research Branch, Agriculture Canada.

A minimum of tu'o outside referees recommend each manuscript submitted for publication in the Bulletm series before it is accepted. 


\title{
The Diptera, or True Flies, of Illinois I. Tabanidae
}

\author{
L. L. Pechuman, Donald W. Webb, and H. J. Teskey
}

The tabanids, or horse flies and deer flies, are well known to dairy farmers and livestock producers as well as to campers, fishermen, and outdoor enthusiasts as annoying and pain-inflicting inhabitants of most wooded areas of Illinois. These large and persistent flies impart a painful bite and can occur in large enough numbers to make canoeing and hiking virtually impossible.

The tabanid fauna of Illinois has never been studied, although several of the surrounding states have published various reports: Indiana (Burton 1975; Meyer \& Sanders 1975), Wisconsin (Roberts \& Dicke 1958), Iowa (Richards \& Knight 1967), Missouri (Andrews \& Wingo 1975), Tennessee (Goodwin 1966), Michigan (Hays 1956), Ohio (Hine 1903), Minnesota (Philip 1931), and Arkansas (Schwardt 1936; Schwardt \& Hall 1930). This study is intended to make available in brief form our present knowledge of the tabanids in the central United States, with keys for their determination, and the distribution of those species occurring in Illinois. No attempt is made to give detailed taxonomic descriptions of species. If needed, these can be found for most species in the papers of Brennan (1935) and Stone (1938). Philip $(1954,1955)$ has keys to all the North American Pangoniinae and Chrysopsinae known at that time. The most recent list of the North American species of Tabanidae is given by Philip (1965).

\section{ACKNOWLEDGMENTS}

The authors wish to express their sincere thanks and appreciation to all of the individuals who have collected tabanids in and around Illinois and have made their collections and data available for this study. Particularly we would like to thank Edward Lisowski for his time, effort, and patience in collecting tabanids throughout Illinois and Drs. Chris Maier, Milton Sanderson, and Gilbert Waldbaues for the Illinois material they have collected over the years.

Special appreciation is extended to J. G. Chainey, British Museum (Natural History), London; L. Tsacas, Museum National d'Histoire Naturelle, Paris; and Margaret K. Thayer, Museum of Comparative Zoology, Cambridge, Massachusetts, for the loan of type material essential to this study. Our sincere appreciation is offered to the following organizations and individuals for the loan of material in their collections: G. Riegel, Eastern Illinois University; R. Wenzel and H. Dybas, Field Museum of Natural History; T. Cashatt, Illinois State Museum; Northern Illinois University; J. McPherson, Southern Illinois University; and $\mathrm{Y}$. Sedman, Western Illinois University.

Photographs of the wings were provided by Howard Lyons, Department of Plant Pathology, Cornell University. Drawings of the tabanid antennae and the abdominal patterns of Tabanus were completed by Miss Donna Baron.

We also wish to thank Dr. Elton J. Hansens, Rutgers University, and Dr. John F. Burger, University of New Hampshire, for their willingness and objectivity in reviewing our manuscript.

Our appreciation is also extended to Mrs. Bernice I. Sweeney for the typing of this mantuscript and to Robert M. Zewadski, Technical Editor, Illinois Natural History Survey, for editing this manuscript for publication. 


\section{NATURAL DIVISIONS OF ILLINOIS}

In studying the tabanid fauna of Illinois, we placed particular emphasis on collecting in unique areas within the state. Fig. 1 illustrates the natural divisions of Illinois based upon the features of topography, soil type, bedrock type, glacial history, and the dis-

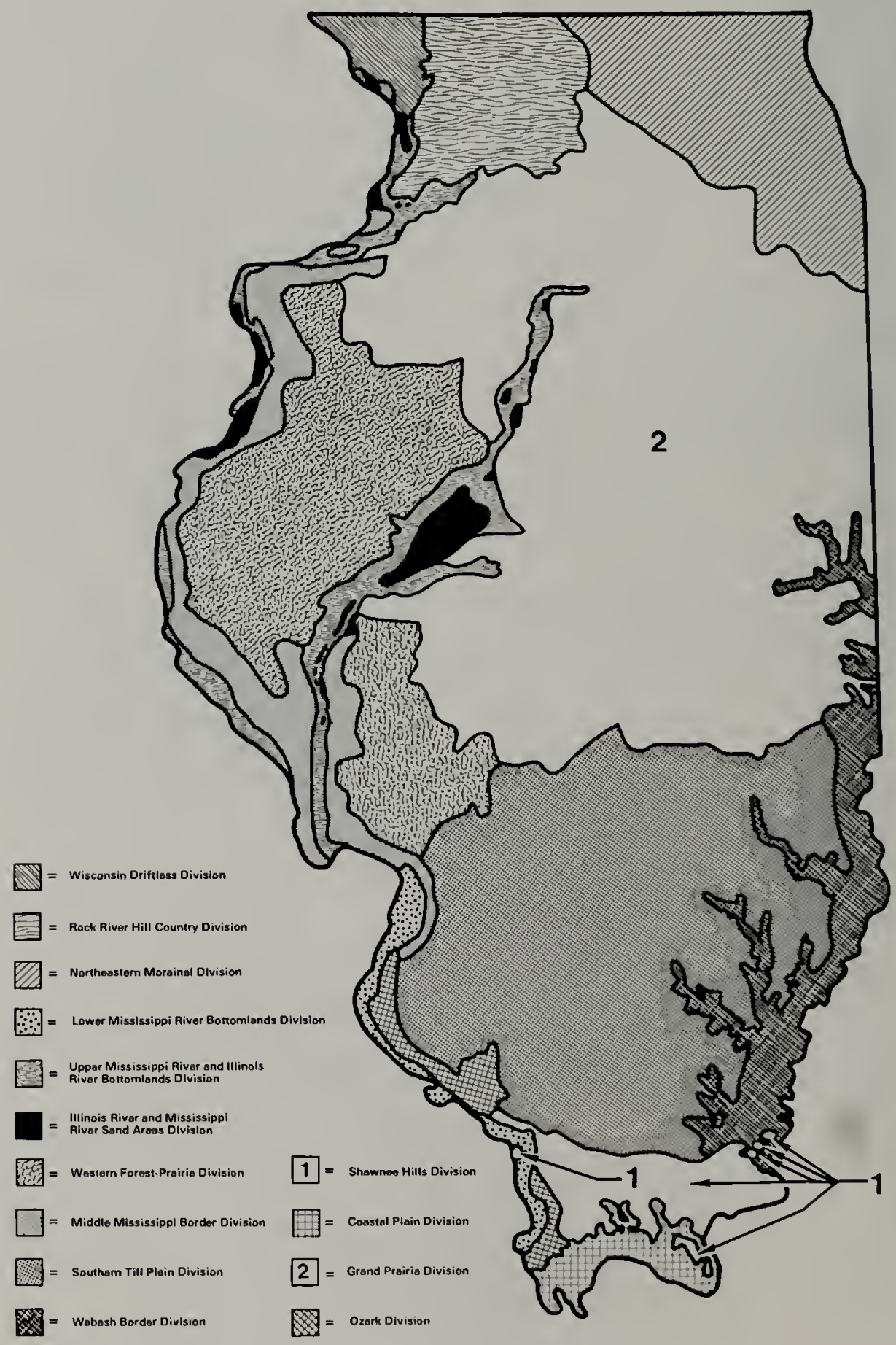

Fig. 1.-The natural divisions of Illinois. (Redrawn from Schwegman 1973) 
tribution of native plants and animals (Schwegman I973).

The Northeastern Morainal Division is the region of most recent glaciation in Illinois. Glacial landforms are common features, including tamarack and sphagnum bogs (Fig. 2) and lakes, fens, marshes and sand terraces (Fig. 3, 4). Boreal tabanids, such as Chrysops mitis, C. sackeni, Atylotus bicolor, A. woodi, Tabanus novaescotiae, Hybomitra frontalis, and $H$. minuscula, have been collected in Illinois only in this area.

The Wisconsin Driftless Division represents an area of northwestern Illinois that apparently escaped Pleistocene glaciation. The topography is one of rolling hills and great relief, particularly along the interior stream canyons (Fig. 5). Although no species of Illinois tabanids are unique to this area, it is one of the few areas in which

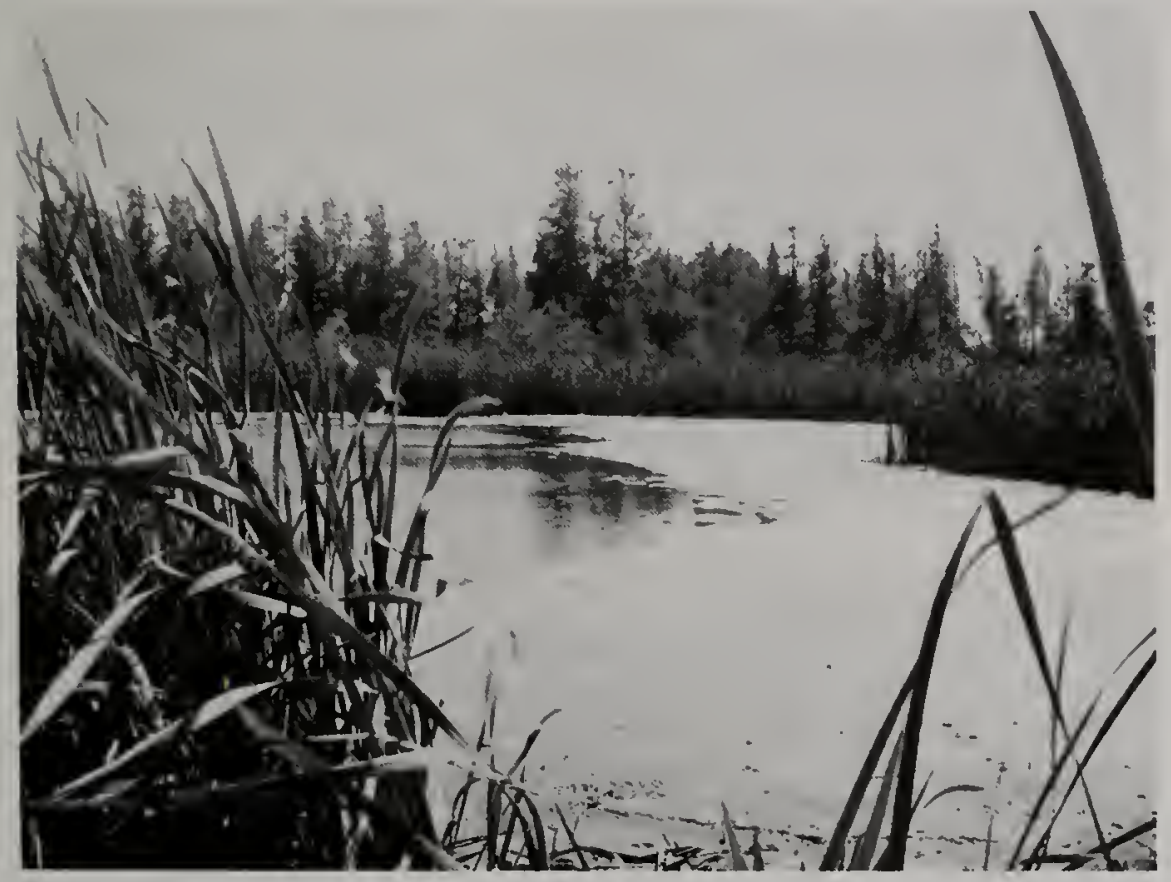

Fig. 2.-Volo Bog: a sphagnum and tamarack bog in Lake County.

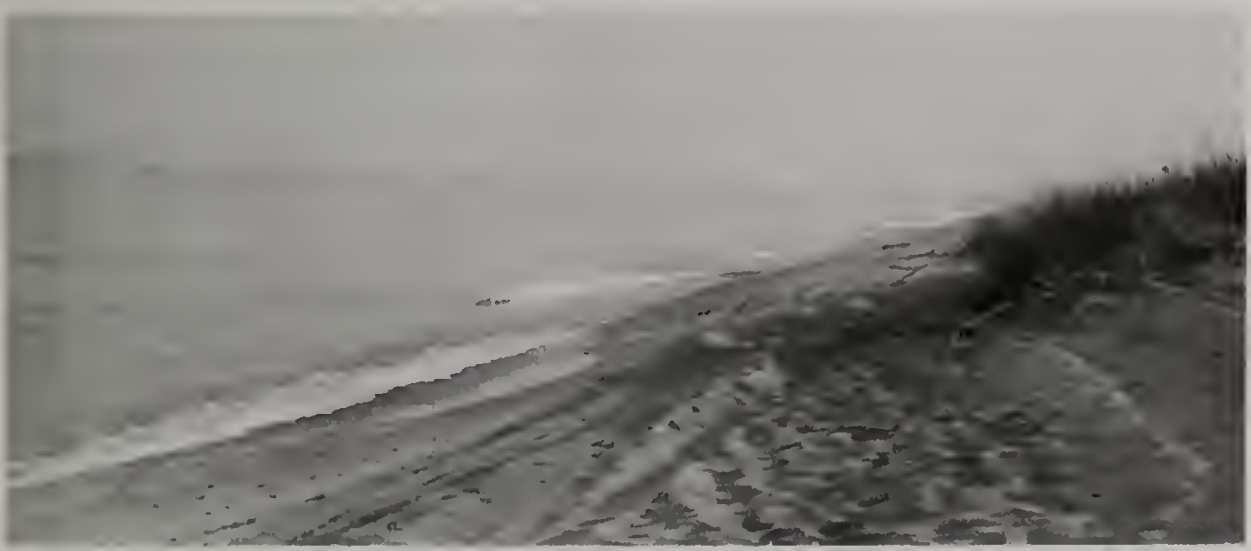

Fig. 3.- Illinois Beach State Park: marshes and sand terraces of the Lake Michigan basin, Lake County. 
Stonemyia rasa, Chrysops inda, and Tabanus trimaculatus have been collected in the state.
The Grand Prairie Division forms the largest natural division in Illinois and was formerly a tall-grass prairie,

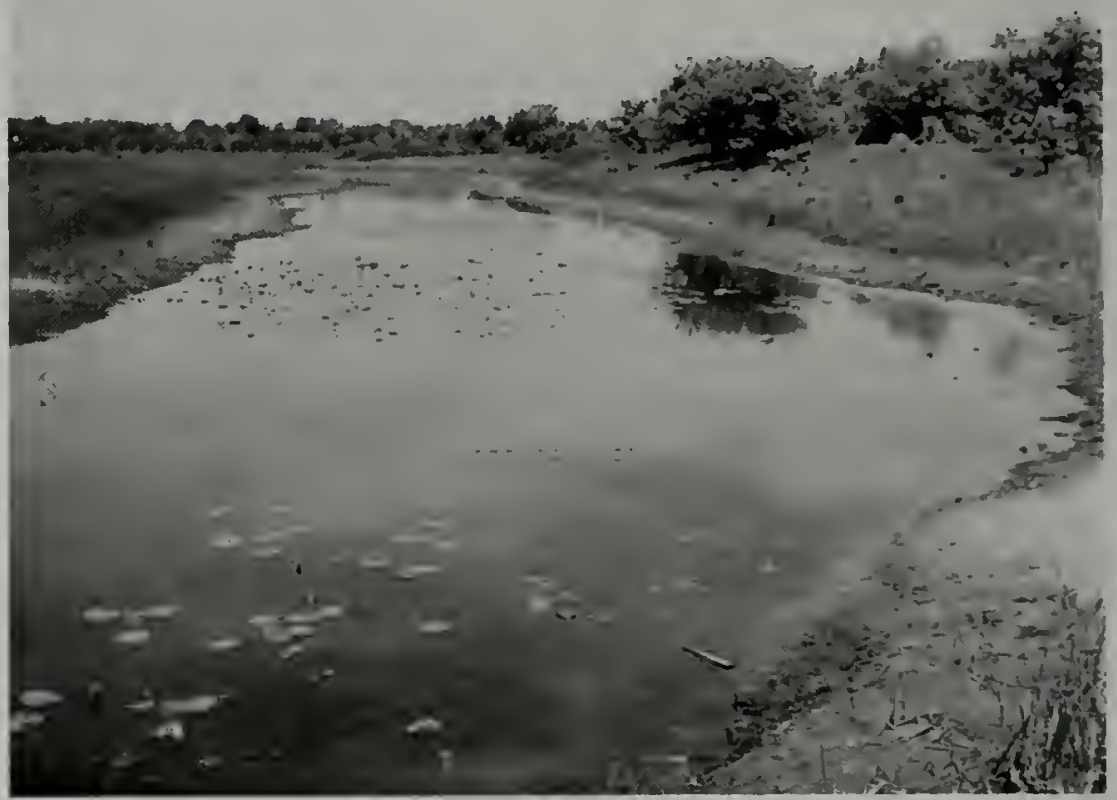

Fig. 4.-Dead River, Illinois Beach State Park, Lake County.

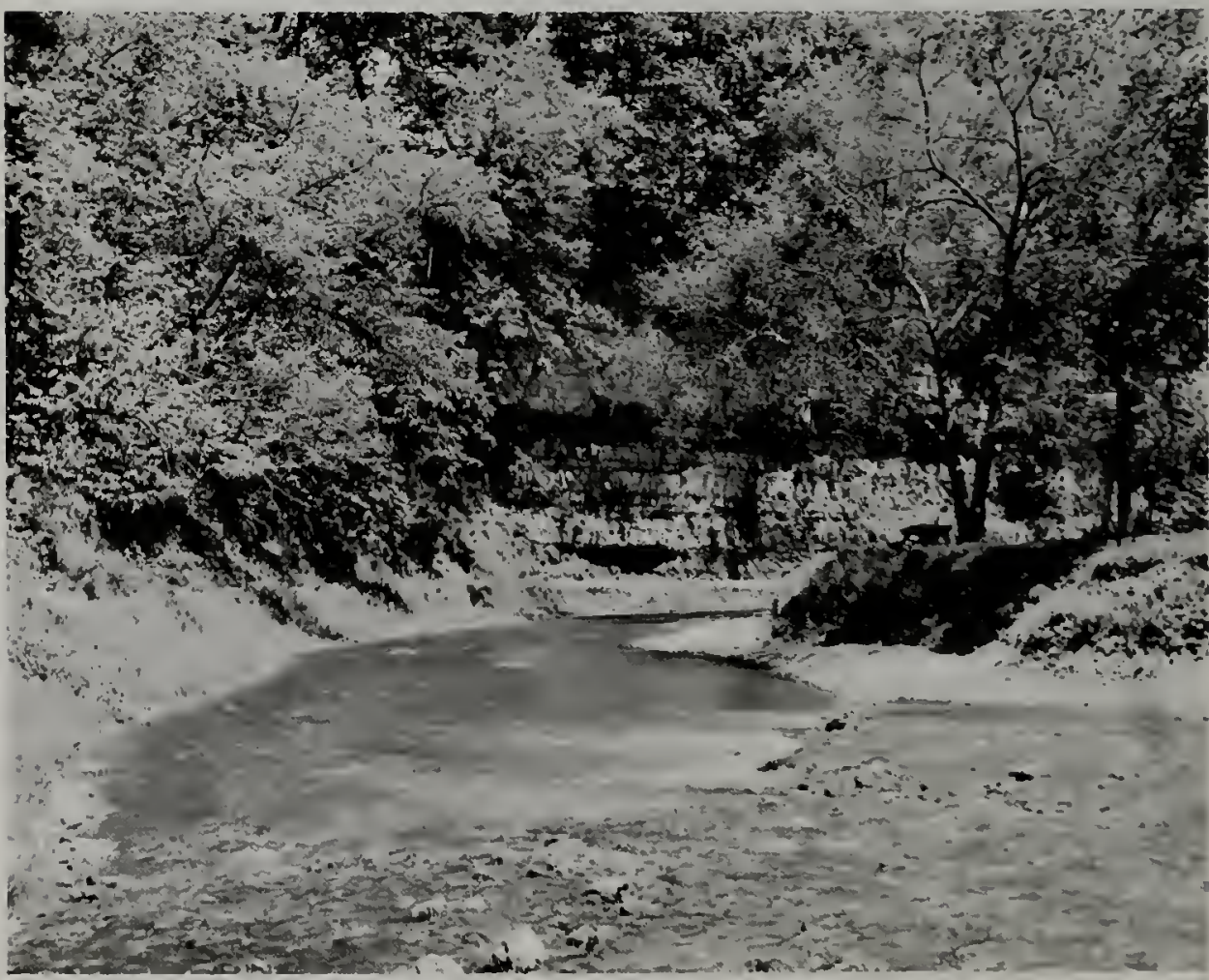

Fig. 5.-Apple River Canyon State Park: an unglaciated drittless area of Illinois, Jo Daviess County. 
April 1983 Pechuman, WebB, \& Teskes: Diptera of Illinols-Tabanihat

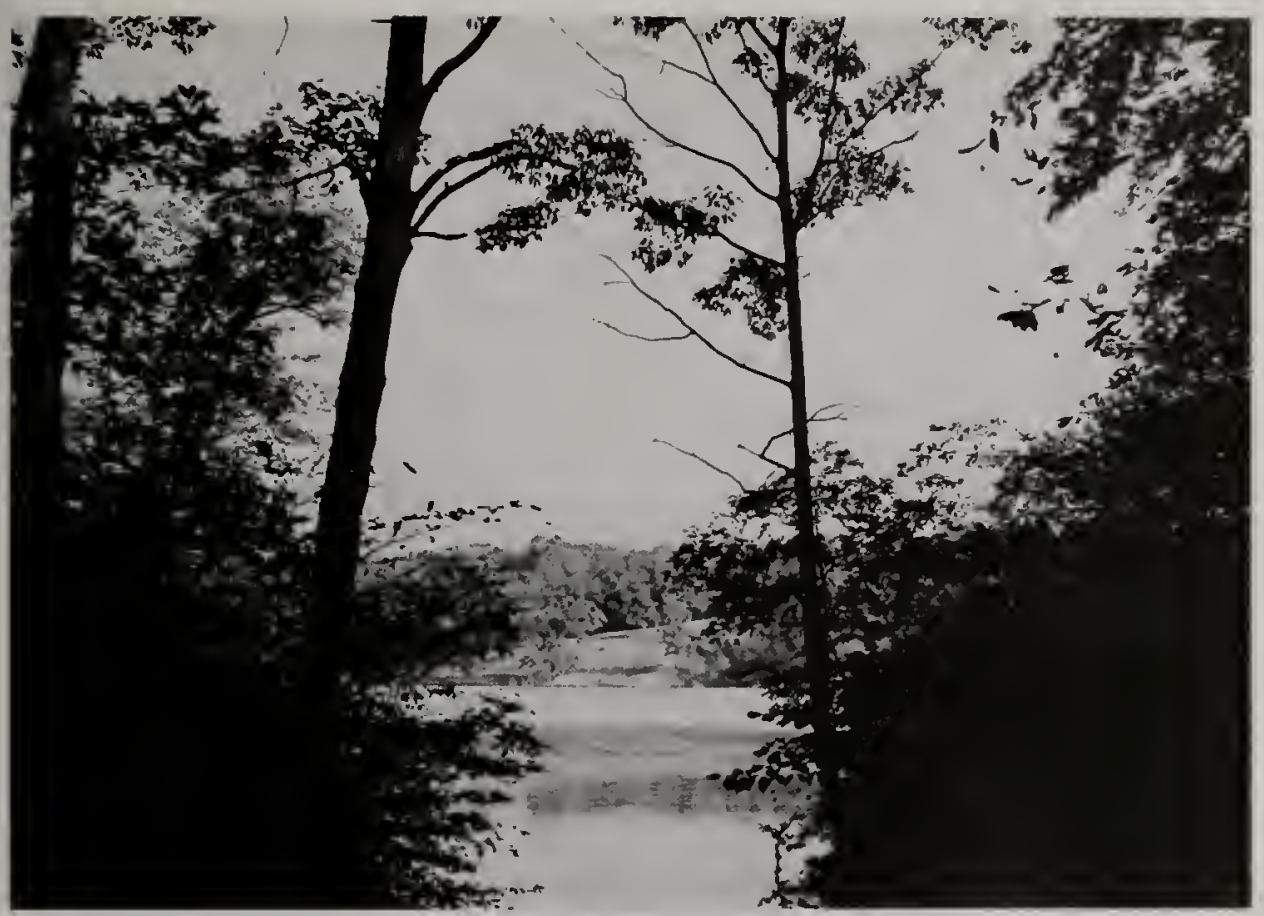

Fig. 6.-Siloam Springs State Park: a flood control reservoir, Adams County.

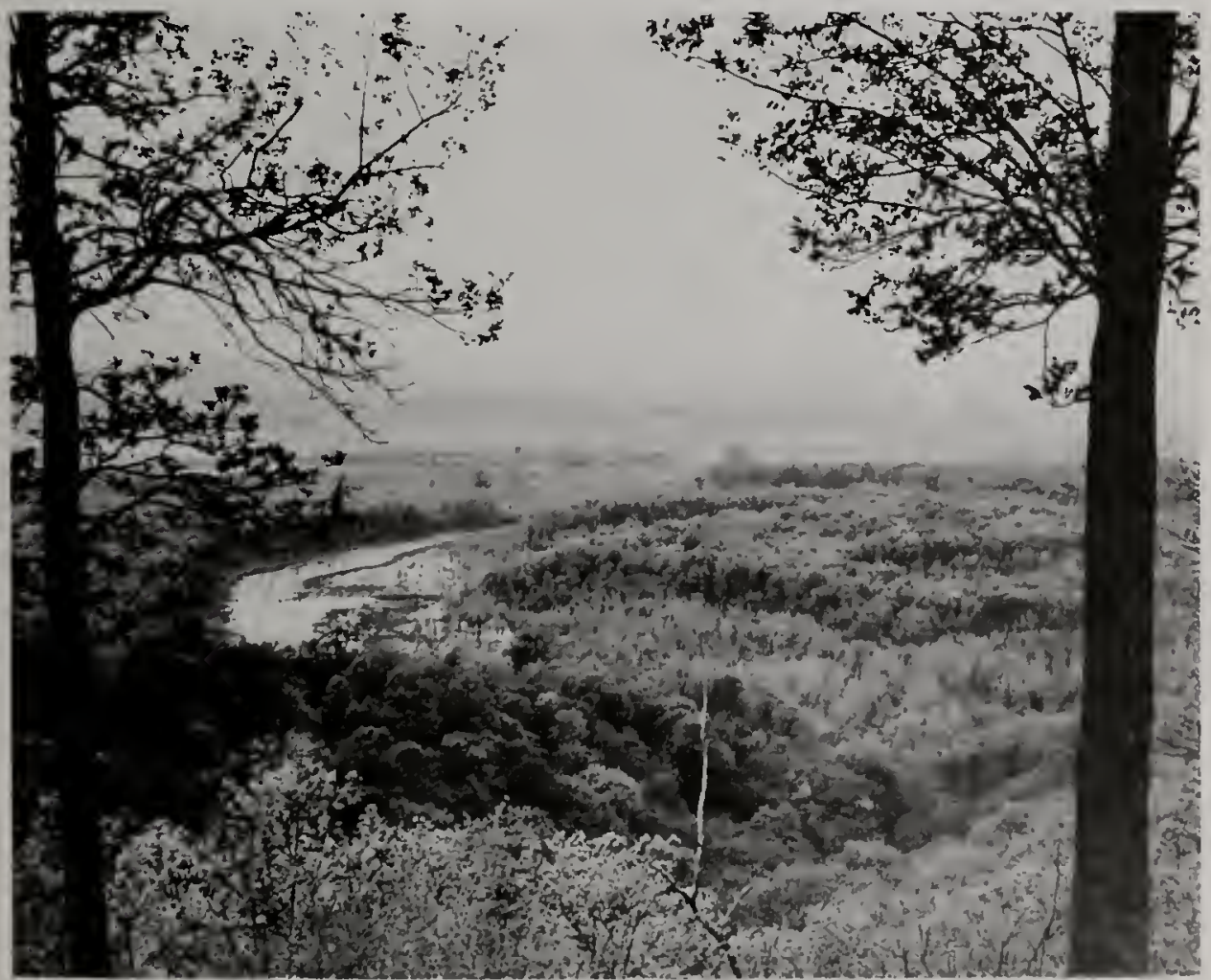

Fig. 7.-LaRue-Pine Hills Ecological Area: part of the Ozark Uplitt in Illinois, Union County. 


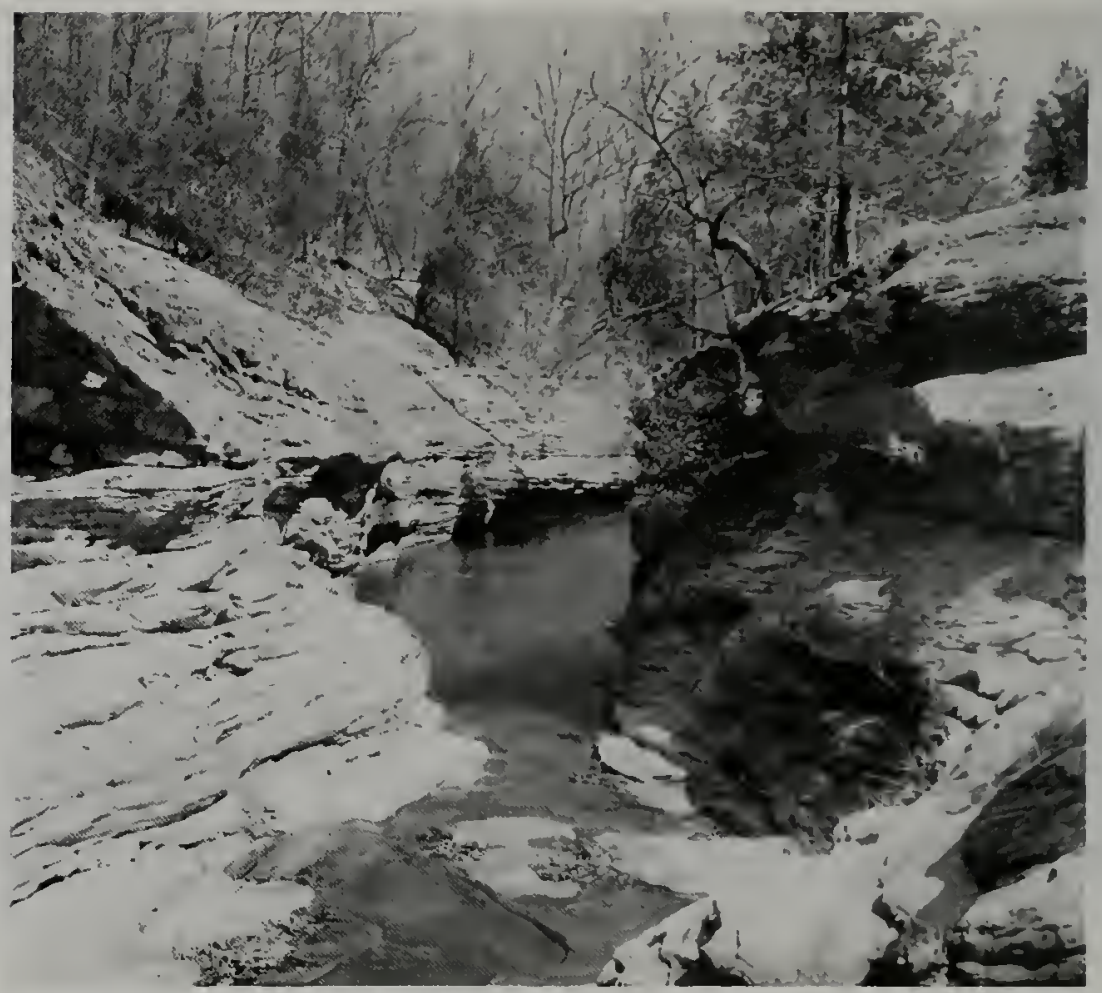

Fig. 8.-Bell Smith Springs Recreational Area: deciduous forest with sandstone cliffs, Pope County.

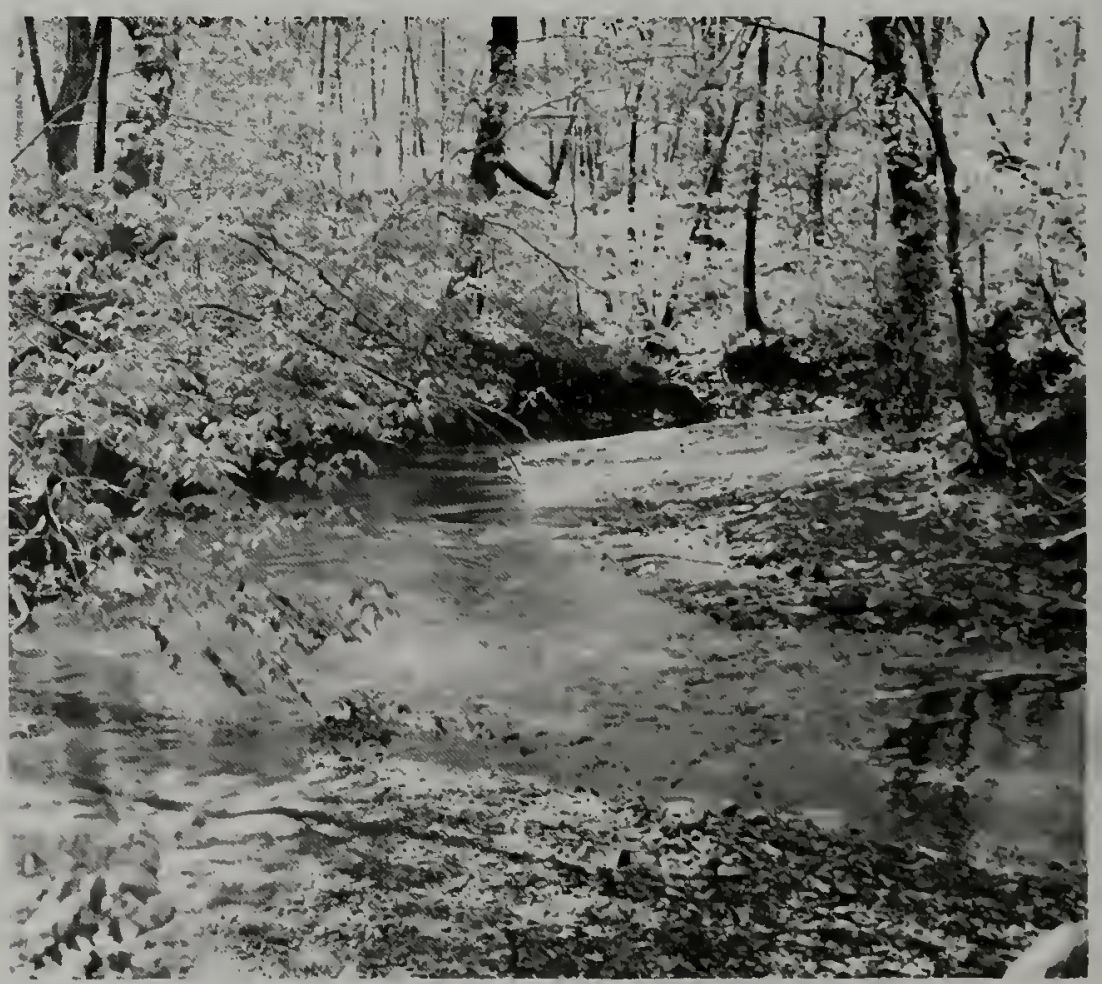

Fig. 9.- Hayes Creek Canyon: deciduous forest, Pope County. 


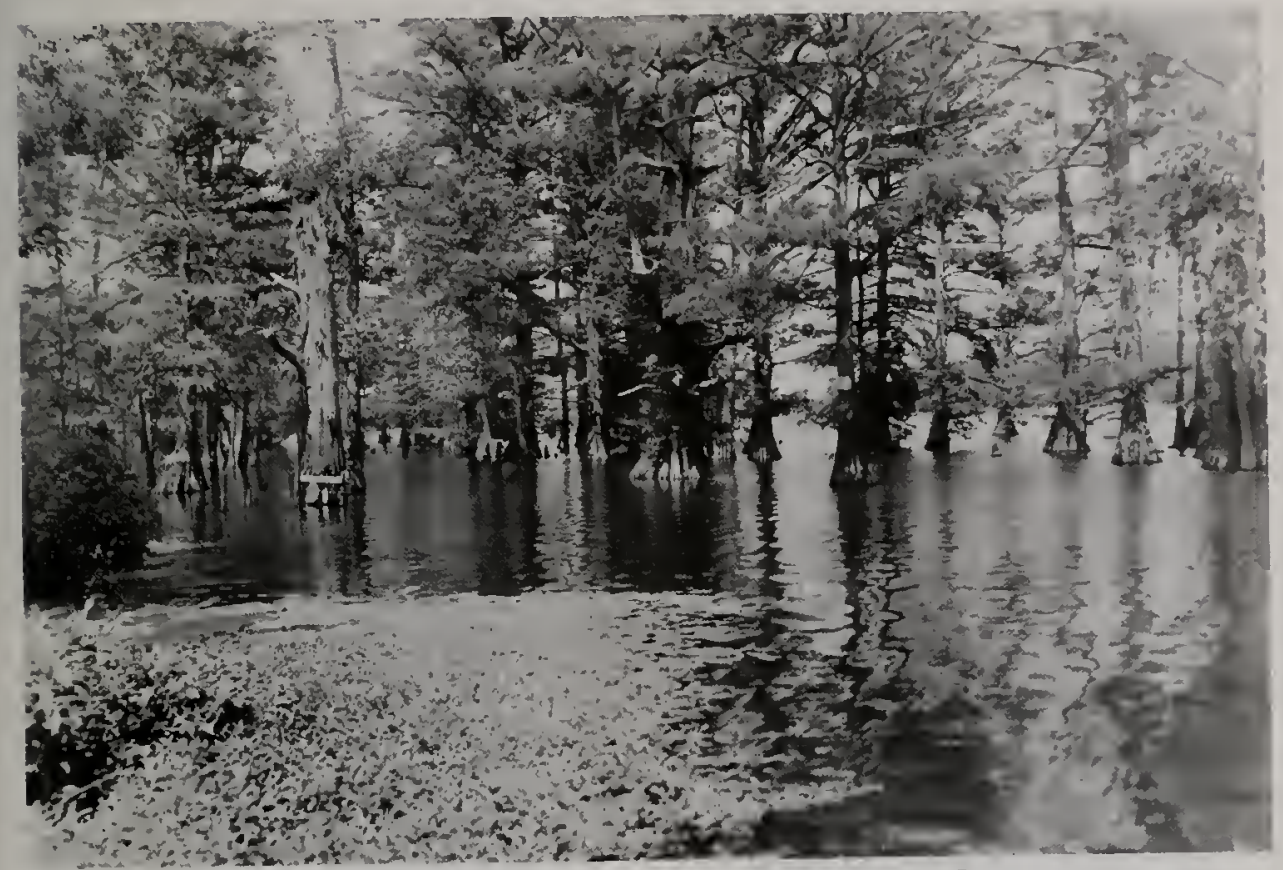

Fig. 10.-Horseshoe Lake: bald cypress and tupelo swamp, Alexander County.

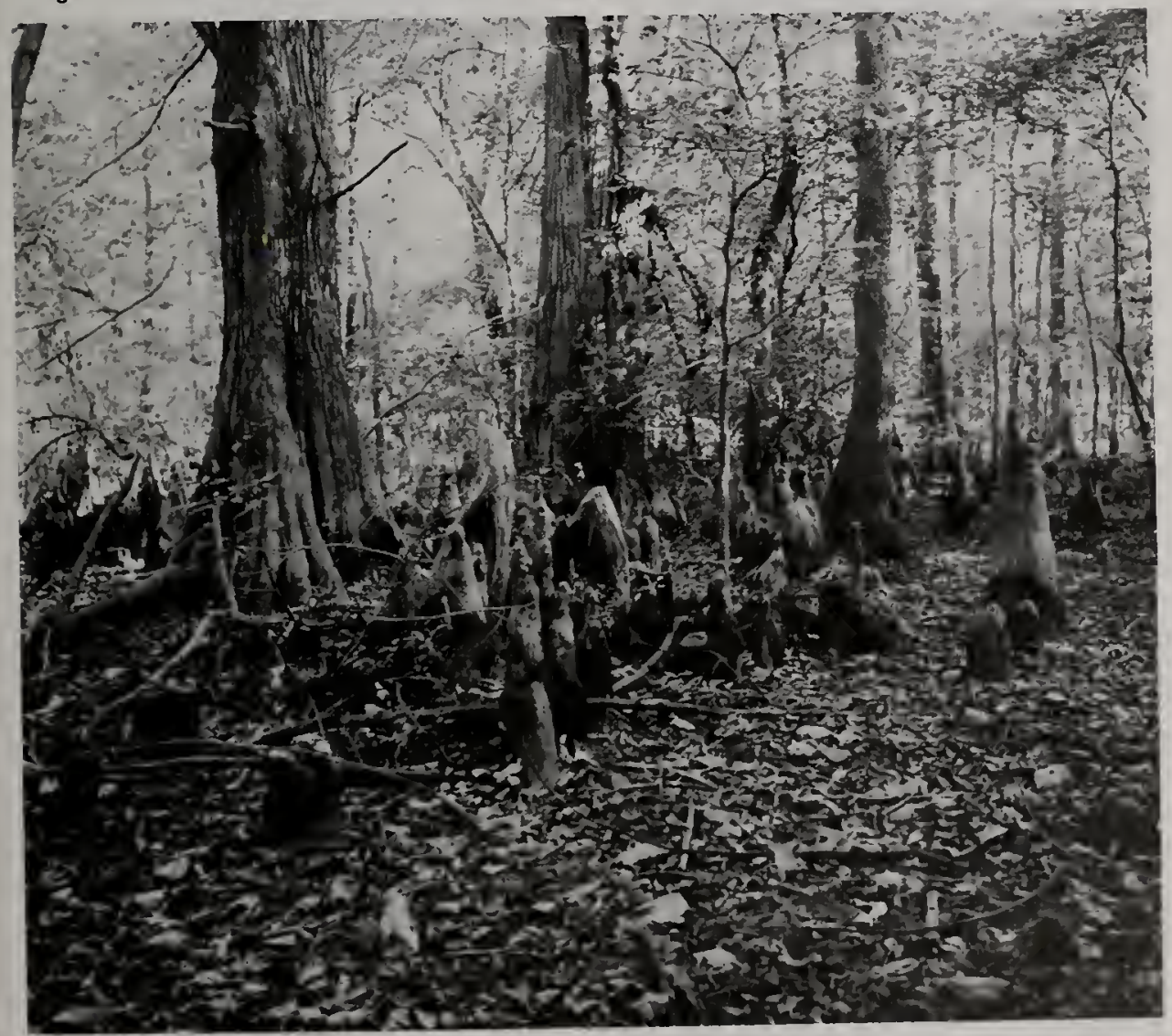

Fig. 11.-Cache River Swamp, a cypress swamp in Johnson County. 
with numerous marshes and prairie potholes. Today it is the most productive agricultural area of Illinois. Numerous species of tabanids have been collected throughout this area.

The Western Forest-Prairie Division is a strongly dissected glacial till plain with many ravines in the level to rolling mesic uplands (Fig. 6). Floodplains are developed along the major streams. Western species of tabanids, such as Silvius quadrivittatus, are often collected in this portion of the state.

The Southern Till Plain Division encompasses most of the area of Illinois dissected by the Illinoian Glacial Till Plain south of the Shelbyville Moraine. Both forest and prairie formerly were present although agricultural practices have greatly modified this area. The soils are relatively poor because of their high clay content. Numerous tabanids with very general distribution patterns have been collected throughout this area.

The Wabash Border Division includes the bottomlands of the Wabash River and its major tributaries. Remnants of the eastern deciduous forest containing beeches and tuliptrees are scattered within forest preserves in this portion of eastern Illinois. Malaise traps in a wooded ravine along the Vermilion River collected Goniops chrysocoma, $\mathrm{Hy}$ bomitra sodalis, and Tabamus sublongus in this area of Illinois

The Ozark Division consists of the Illinois part of the Salem Platean of the Ozark Uplift. This area is mostly forested (Fig. 7) but contains scattered hill prairies. The division contains many Ozarkian, southern, and southwestern plants and animals that are rare or absent elsewhere in Illinois. Chrysops pudicus was collected at several locales in this area but nowhere else in the state.

The Shawnee Hills Division extends across the southern portion of Illinois from the Mississippi River to near the mouth of the Wabash River. This unglaciated hill country is characterized by a high east-west escarpment of standstone cliffs. Originally this divi- sion was mostly forested, and considerable forest remains. The topography is very rugged, with many bluffs and ravines (Fig. 8, 9). A variety of tabanids have been collected in this region.

The Coastal Plain Division is a region of swampy forested bottomlands and low clay and gravel hills that is the northernmost extension of the Gulf Coastal Plain Province of North America. Bald cypress (Fig. 10. 11) and tupelo gum swamps are unique features of this division in Illinois. Tabanids such as Chrysops celatus, $C$. dimmocki, C. reicherti, C. separatus, and Neochrysops globosus have been collected in Illinois only from this area.

\section{NATURAL HISTORY}

\section{Immature Stages}

Although extensive work has been done on the biology of many species of tabanids in Nortl America, the work of Teskey (1969), Teskey \& Burger (1976), Tidwell (1973), Tidwell \& Tidwell (1973), and Goodwin (1972, 1973a, 1973b, 1976a, 1976b) has done much to increase our knowledge of the systematics and biology of the immature stages; these papers should be consulted when identification of the inmature stages is required.

Eggs of many species are laid in masses on vegetation above water (Fig. 12-I4) or moist ground although logs. rocks, and bridge abutments are also used for this purpose. The egg mass is whitish when freshly laid (Fig. 14) but soon darkens to various shades of brown to jet black. depending on the species. Some species of Chysops lay a single-tiered egg mass (Fig. 14), and Hybomitra and Tabamus generally have egg masses of more than one tier (Fig. 12).

The larvae of Illinois Tabanidac are relatively well known as a result of work in adjacent areas by Burger (1977), Goodwin (1972, 1973a, 1973b. 1976a, 1976b). Teskey (1969). Teskey \& Burger (1976). Tidwell (1973). Tidwell \& Tidwell (1973), and others. Larvae of 77 of the 109 species 


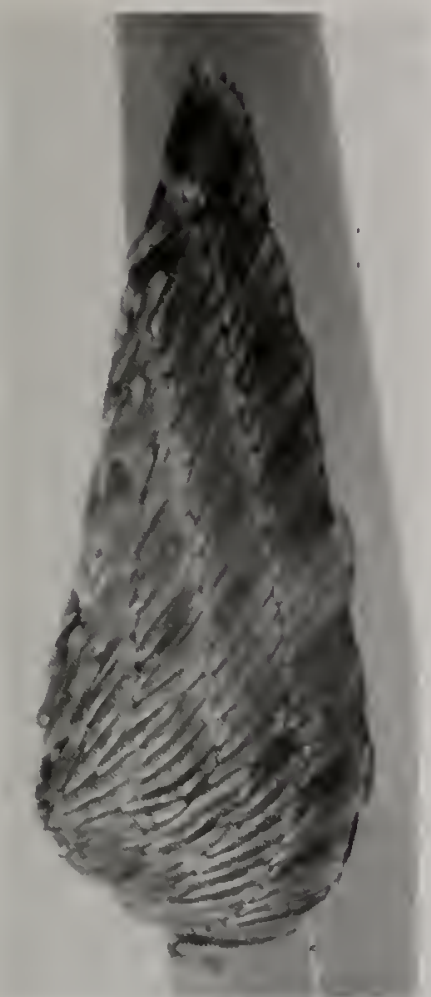

Fig. 12.-A lateral view of a horse fly egg mass.

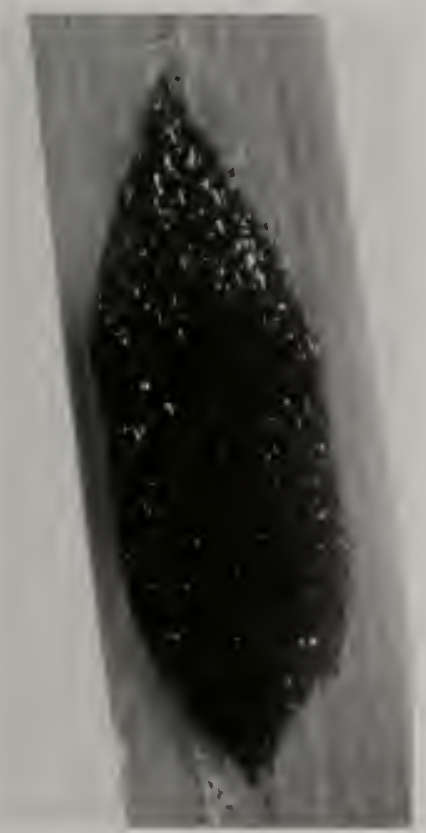

Fig. 13.-An enlarged view of a deer fly egg mass. Many species of Chrysops deposit egg masses of this general type.

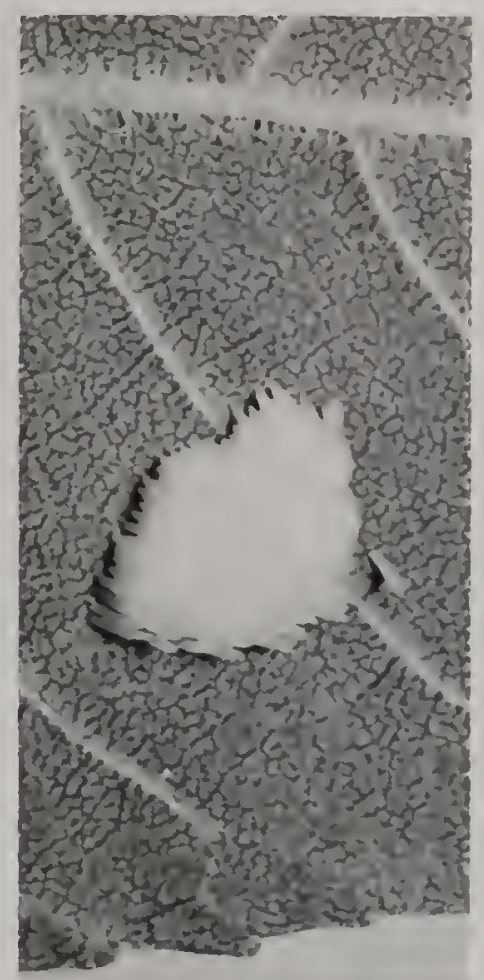

Fig. 14.-Fresh egg mass of Chrysops moechus, quite different from those of most species of Chrysops.

recorded or potentially to be found in Illinois have been described. However, because the larvae of 32 species are still unknown, and as some of them are probably very similar to known larvae, great care must be taken in identifying larvae.

Tabanid larvae are distinctive on the bases of the characteristic shape and features of the head capsule, the encircling bands of 3 or 4 pairs of wartlike prolegs on the first 5 or 7 abdominal segunents (except in Goniops), and in particular, the characteristic features of the posterior spiracles. The elongate, anteriorly tapered head capsule with slender, pointed, ustrally curved mandibles and the mandibular brush of spines situated dorsolaterally above the base of each mandible is shown in Fig. 77. Such a head capsule is common to all of the Tabanoidea 
(Athericidae, Pelecorhynchidae, Rhagionidae, and Tabanidae).

Exposed portions of the posterior spiracles are in the form of a pair of closely appressed vertical linear bars, or a bladelike spine situated at the apex of a short respiratory siphon, or at least a circularly delineated area at the apex of the terminal segment (Fig. $78-80)$. It is worth noting that the actual site of air exchange is not associated with the bars or spine but rather within a slit at either side of these visible features.

Other features of particular importance in the identification of tabanid larvae are shown in Fig. 87. The extent of pubescence on various aspects of the body is the most important diagnostic feature. Pubescence is normally restricted to the anterior and posterior segmental borders and the posterior margin of the prolegs of a variable number of segments. Such pubescence is referred to as anterior, posterior, and proleg pubescence (Fig. 86). In addition, pubescence may occur in a characteristic configuration midlaterally on the terminal (or anal) segment and as narrow extensions posteriorly from anterior pubescence on one or more thoracic segments and anteriorly from posterior pubescence on the penultimate (preanal) segment. As this pubescence may be extremely pale, proper illumination is the key to accurate interpretation. Combinations of reflected and transmitted light (or backlighting) of varied intensities must be used. In some cases the pubescence may only be seen in profile. It may be necessary to slide mount larval exuviae in glycerime for viewing at high magnification under a compound microscope.

Identifications can be made of living or preserved larvae or of larval exuviae. However, it is necessary to slow the movement of living larvae. This is most easily accomplished by immersing the larvae in ice water. A styrofoam insulating block excavated to hold an individual ice cube contain- er is ideal for use under a stereoscopic microscope. A wire window screen platform wedged at half the depth of the container serves to support the larva and to prevent the ice in the lower half from floating. Preserved larvae and exuviae can be viewed while they are immersed in the preserving fluid in shallow dishes.

The larval stages of most species live under moist conditions, varying from aquatic habitats to moist soils and from rapidly flowing streams to stagnant ponds. Some species are found only in sphagnum bogs (Fig. 2). The larvae of some species live in relatively dry soil and others in rotten wood. Some species show great tolerance of variation in larval habitat.

The larvae of many species of Tabanus and Hybomitra are known to be carnivorous, but the food requirements of the various species of Chrysops are unknown.

The larvae of most species look much alike to the casual observer. They are usually white, but may be brownish or greenish, tapering at each end (Fig. 85-9I). The larvae of Goniops chnsocoma is bottle shaped (Fig. 81). The larvae of some species have dark bands (Fig. 203). When full grown. the larvae of many species move to drier situations to pupate. As far as is known, all species overwinter as larvae.

The pupae are brown or straw colored with a row of stiff spines encircling the apical third of each abdominal segment. At the apex of the abdomen are 6 stout, sharply pointed projections forming the pupal aster. The pupal stage requires from 1 to 3 weeks, depending on the species and the temperature.

Under Illinois conditions. most species have one generation a year. There is some evidence, however, that Tabanus lineola and $T$. similis may occasionally develop from egg to adult in one season. Some individuals of $T$. atratus and other large Tabamus species may take 2 or 3 years to complete their development. The emergence of the 
males of a given species normally is slightly in advance of the main emergence of the females.

\section{Habits of Adults}

Most female horse llies and deer flies suck blood and attack both hilmans and animals. The males, which do not suck blood, are generally collected from flowers or foliage. Tabanids of both sexes frequently rest on paths and roads, especially those in wooded areas (Fig. 8, 9, 10, 11). Hybomitra difficilis, H. microcephala, and Tabanus sulcifrons have a decided proclivity for such situations. The fenales often enter buildings in considerable numbers and tend to congregate at windows since they are attracted to light. Both sexes of many species occasionally come to lights at night, and almost all males of Tabanus pumilus and $T$. sackeni have been taken at lights.

Tabanids are most active on warm sunny days when there is no wind. A slight drop in temperature or a sudden breeze greatly reduces the number of attacking females. There are exceptions to this rule, however; Pechuman (1972) reported being attacked by Chrysops moechus after dark and by $C$. indus at uncomfortably cool temperatures. Some species are normally crepuscular or nocturnal; these include Tabanus sackeni and probably T. sublongus.

Moving objects and dark objects seem to be most subject to attack. Pechuman (1972) noted that predominantly dark cattle in a herd usually have the most horse flies feeding on them.

Althongh the immature stages of most tabanids inhabit wet or moist conditions, adults are often numerous some distance from breeding areas.

\section{Natural Enemies}

There is an extensive but scattered literature on the natural enemies of tabanids, but the following discussion is restricted to those applying to Illinois species.

Adults are preyed upon by birds, dragonflies (Odonata), robber flies (Asilidae), and wasps of the genera Vespula, Crabro, and Bembix. Crabro monticola and some species of Bembix provision their nests with quantities of tabanids, but the populations of these wasps do not seem to be large enough to have any appreciable effect on tabanid populations. Adult tabanids are found in spider webs, but this is not common except at windows inside barns.

Larvae and pupae are parasitized by Hymenoptera of the families Diapriidae and Pteromalidae and by Diptera of the families Bombyliidae and Tachinidae, but these seem to do little toward reducing populations. Teskey (1969) reports that only 2 percent of the larvae he collected were parasitized although in specific localities the percentage might be higher. On one occasion, in an area where there were numerous egg masses of Chrysops moechus, Pechuman (1972) noted that many freshly hatched larvae became entangled and died in webs of tetranychid mites on the leaves. Shore birds feed to some extent on tabanid larvae.

Parasitism of eggs by the hymenopterous families Trichogrammatidae and Scelionidae is apparently common.

The cannibalistic habits of Hybomitra and Tabanus larvae are suspected to have a greater effect on larval populations than do predators and parasites.

\section{Economic Importance}

Because of their medical and veterinary importance, both by direct injury and by the transmission of disease organisms, the economic importance of lıorse flies and deer flies has received wide attention (Webb \& Wells 1924; Philip 1931; Anthony 1962; Jamnback 1969).

Tabanids are vectors of several diseases of man and animals caused by such organisms as viruses (equine infectious anemia, vesicular stomatitis, hog cholera, California encephalitis), bacteria (anthrax, tularemia), rickett- 
sia or rickettsia-like organisms ( $Q$ fever, anaplasmosis), trypanosomes (surra, mal de caderas, murrina), and filarial worms (loaiasis, elaeophorosis), which have been discussed in Anthony (1962), Jones \& Anthony (1964), DeFoliart et al. (1969), Wright et al. (1970), and Tidwell et al. (1972).

Most of these disease organisms are transmitted mechanically. Since tabanid bites are painful, the host makes an effort to dislodge the biting fly, and since tabanids are nervous and alert feeders, they are easily disturbed. When dislodged, the fly returns to the attack but may select a nearby host. If the first host has disease organisms in its blood, some of these adhering to the proboscis may be injected into the blood of the second host. Although some of the diseases mentioned are present in Illinois, only anaplasmosis is reasonably common, occurring in the spring and fall in southern Illinois.

The biological transmission of the filarioid parasite Elaeophora schneideri to deer, elk, and domestic sheep by various species of Tabanus and Hybomitra has been reported by Hibler et al. $(1969,1970,1971)$.

\section{Control}

Little of a positive nature can be said about the control of horse flies and deer flies. Applications of insecticides to restricted areas have been of little value, and applications over wide areas have been only moderately effective while increasing the danger to nontarget organisms. Insecticides have given more successful control of the larvae than of adults, but damage to other organisms has been even greater (Jamnback \& Wall 1959).

Repellents for use on livestock have shown some promise, but their effects are of short duration. The standard repellents commercially available for human use, and effective for mosquitoes and black flies, are generally useless as deer fly repellents. In fact. the shiny appearance of the skin after using them may even attract the flies.

Natural enemies show little promise as controls, although mass releases of egg parasites would be expected to cause some population reduction.

Sudden changes in water level are destructive to some species, and manipulation of water levels has been fairly effective in Connecticut (Anderson \& Kneen 1969). However, such manipulation is not often possible. Drainage reduces the available breeding areas for many species, but it may actually increase larval habitats for such species as Tabanus quinquerittatus.

On farms with small ponds and seepage areas, most emergent vegetation can be removed to reduce oviposition sites significantly. Egg laving is thus concentrated on the small amount of vegetation remaining, and this can be destroyed with its load of egg masses. However, this procedure is not practical for large bodies of water and swamps.

The most promising method of control, at least in limited areas, is the use of trapping devices. Shining black panels covered with sticky substance and baited with dry ice are quite effective for Tabanus. Canopy traps of the general type described under Collection and Preservation (Fig. 17) and box traps are used in the coastal areas of several states to reduce tabanid populations on beaches and golf courses. In New York canopy traps are used on stud farms and are regarded as successful. Pechuman (1972) used such a trap near a swimming pool where horse flies were attacking swimmers, and the resulting reduction in flies was dramatic.

\section{COLLECTION AND PRESERVATION}

Horse flies and deer flies can be collected in the situations mentioned under Habits of Adults. Females can be taken as they attack animals and humans, from windows in buildings, and from cars parked with open windows. Both sexes can be collected from flowers, by sweeping vegetation with an insect net, from roads in wooded areas, and from lights at night. Some species of wasps of the genera 
Crabro and Bembix capture tabanids to provision their nests, and excellent specimens of both sexes can be obtained by capturing the wasps as they approach their nests or by digging out the nests. Males of certain species can be collected as they hover along roads or in clearings, and other males can be found at dawn on exposed rocks in elevated situations. Collecting larvae and rearing adults from them will pro- more selective and the catch is largely restricted to horse flies. Unlike the Malaise trap, it rarely collects male specimens. The canopy is shining black plastic below and transparent plastic above, with the bottom about $60 \mathrm{~cm}$ from the ground. A shining black sphere (a beach ball painted glossy black) about $60 \mathrm{~cm}$ in diameter is suspended about $30 \mathrm{~cm}$ from the ground by a cord. The color and its

Fig. 15.-Horizontal Malaise trap used in collecting tabanids.
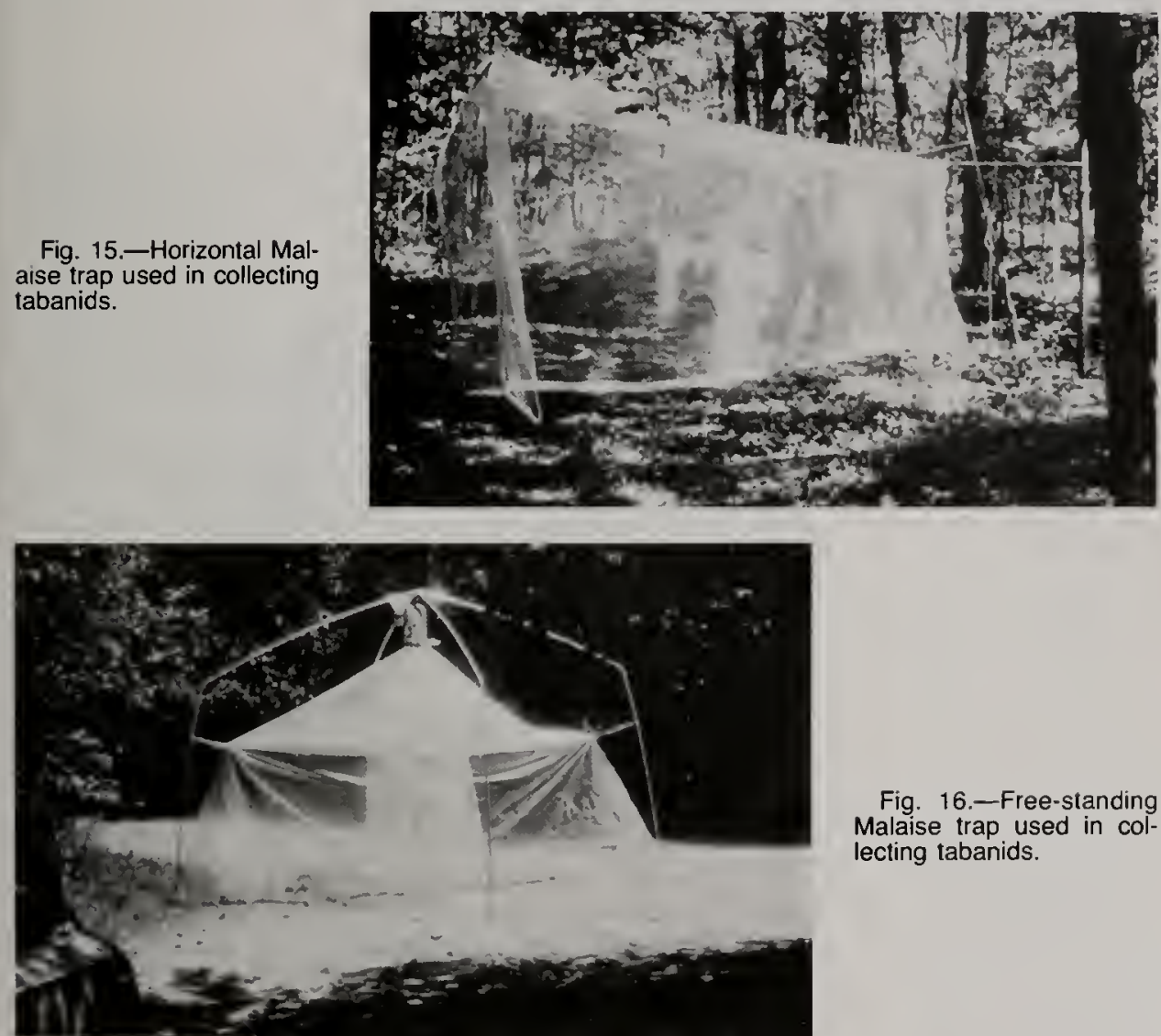

Fig. 16.-Free-standing Malaise trap used in collecting tabanids.

duce about equal numbers of both sexes.

The use of traps will yield large numbers of specimens. Traps used in obtaining material for this paper were of three types. The Malaise trap is placed to form a barrier that intercepts the flight of tabanids and other insects. Two different types of Malaise traps were used during this study (Fig. 15, 16). The canopy trap (Fig. 17) is reflection, and possibly heat from the canopy and sphere, and the movement of the sphere attract horse flies under the canopy; many of these then fly upward and are caught in a collection apparatus. Such a device can be a simple plastic or wire dome with an inverted funnel within it to prevent escape of the specimens; this type of collecting lead is usmally used when control is the main object. A some- 


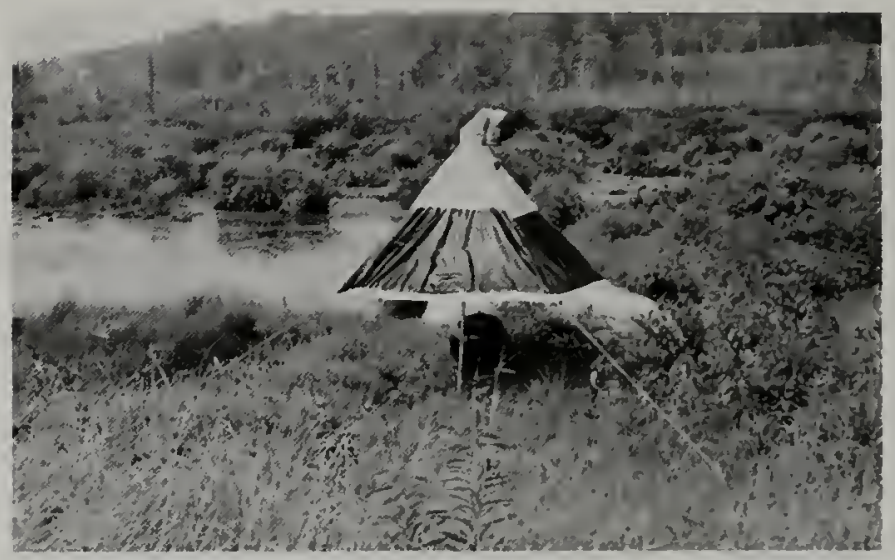

Fig. 17.-Canopy trap used in collecting tabanids.

Fig. 18.-One type of collecting head used with a canopy trap.

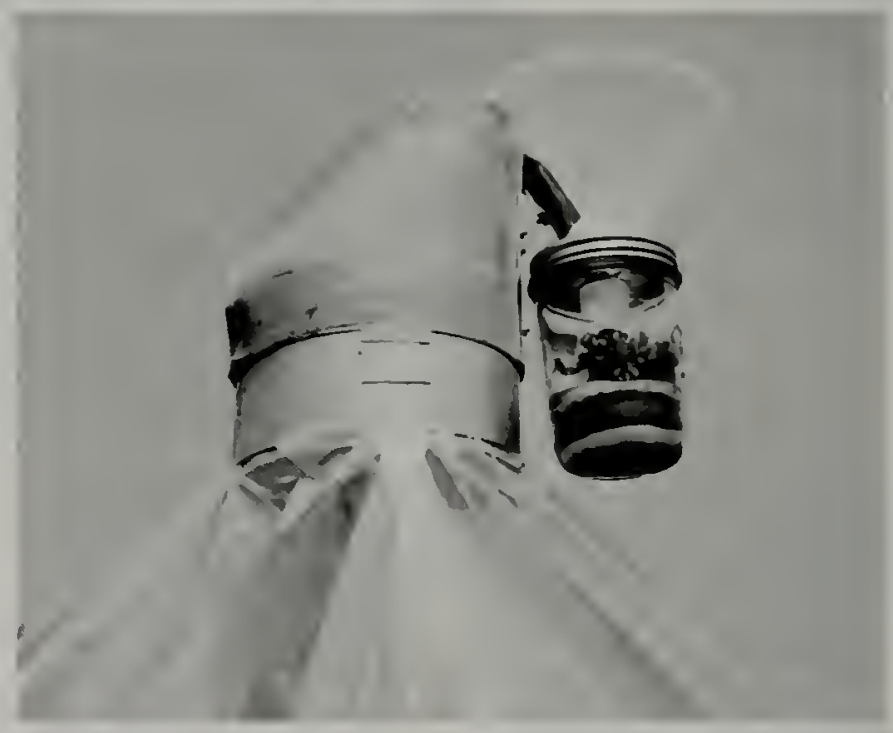

what more complicated device (Fig. 18) produces better quality specinems for study. If dry ice or another source of carbon dioxide is placed near the top of the canopy, the catch is increased considerably.

Horse flies and deer flies are easily preserved, but the specimens must be of good quality. They should be pinned through the right side of the thorax on the day of collection; no further treatment is necessary. All, of course, should carry the usual locality label with date of collection and collector's name. A second label with loust, ecological situation, and a diagram of the eye pattern (which disappears shomty after death) is helphul.

Flies not pinned when lresh rarely make good specimens for study. If these are moistened so they can be pinned, much of the body pattern. often important for species determination, may be destroyed. Specimens preserved in alcohol have the same disadvantage. Reasonably good specimens can be mounted from alcohol if they are placed overnight in cellosolve, transferred for about an hour to xvlene, and then pinued. Specimens mounted directly from alcohol are almost worthless.

Pinned specimens that are dirty or greasy can be cleaned by inmersion in ethyl acetate for several hours.

Techniques for collecting and rearing the immature stages of tabanids have heen described by Teskey $(1962,1969)$. 


\section{CLASSIFICATION}

Horse flies and deer flies belong to the family Tabanidae, which is worldwide in distribution and comprises more than 3,000 described species. The most modern classification on a worldwide basis is that of Mackerras (1954), and for North America that of Philip (1957, 1965).

The family is divided into three subfamilies and each subfamily into tribes; not all tribes are represented in 1llinois. A listing by subfamily and tribe of the genera found or likely to be found in Illinois follows.

PANGONIINAE:

Species found in Illinois

Pangoniini

Stonemyia

Scionini

Goniops

CHRYSOPSINAE:

Bouvieromyiini

Merycomyia

Chrysopsini

Chrysops

Silvius

Neochrysops

TABANINAE:

Diachlorini

Diachlorus

Chlorotabanus

Haematopotini

Haematopota

Tabanini

Atylotus

Leucotabanus

Tabanus

Hybomitra

Hamatabanus

\section{TAXONOMIC CHARACTERS}

Distinctive structural characters are few in the Tabanidae, and most of them are confined to the head and its appendages. Chaetotaxy, so useful in many groups of Diptera, cannot be used, since macrochaetae are not present. Since distinguishing structural characters are few, much dependence is placed on ground color and pilosity, and these must be used with caution on partly denuded specimens.
Some characters of the head are restricted to females, requiring the use of separate keys to the males of Chrysops, Hybomitra, and Tabanus. Since males do not attack man or animals, they are much less common in collections than females; the male of several North American species is still unknown. Males are easily recognized by the continguous eyes.

With Fig. 19-22 as guides, most of the characters used in the keys can be readily understood.

\section{KEY TO GENERA OF TABANIDAE}

\section{Adults}

I. Hind tibiae with 2 apical spurs .................

Hind tibiae without apical spurs ..............7

2. Third segment of antenna with 8 distince annuli (Fig. 23, 24) ...................3

Third segment of antenna with 5 or fewer distinct annuli (Fig. 26) ...............4

3. Eyes of female with upper inner angles acute; frons broader than width of eye; wings with dark pattern (Fig. 37) Goniops

Eyes of female normal; frons narrower than width of eye; wings hyaline (Fig. 36) Stonemyia

4. Third antennal segment with rather broad basal plate, 2 or 3 annuli (Fig. 25); first antennal segment only slightly longer than wide, lotal length of antennae equal to or shorter than thickness of head; large species with very small tibial spurs ....................Merycomyia

Third antennal segment with rather narrow basal plate, 4 annuli (Fig. 26); first antennal segment usually at least Iwice as long as wide, total length of antennae greater than thickness of head; hind tibial spurs pronounced .....5

5. Abdomen globose, wider than thorax, with 2 rows of dark spols; wings rather evenly fumose (Fig. 74) ...........

\section{Neochrysops}

Abdomen slender, variously marked or unpalterned; wings only rarely evenly fumose

6. Wings with isolated clouds (Fig. 73); second antennal segment nol more than half length of first (Fig. 27) .....

Silvius (Griseosilvius)

Wings with dark crossband or traces of such band; first 2 antennal segments subequal (Fig. 26).

Chrysops

7. First antennal segment distinctly longer than wide (Fig. 29); frons of female widened below, broader than high; wing with gray maculations (Fig. 76)

Haematopota 

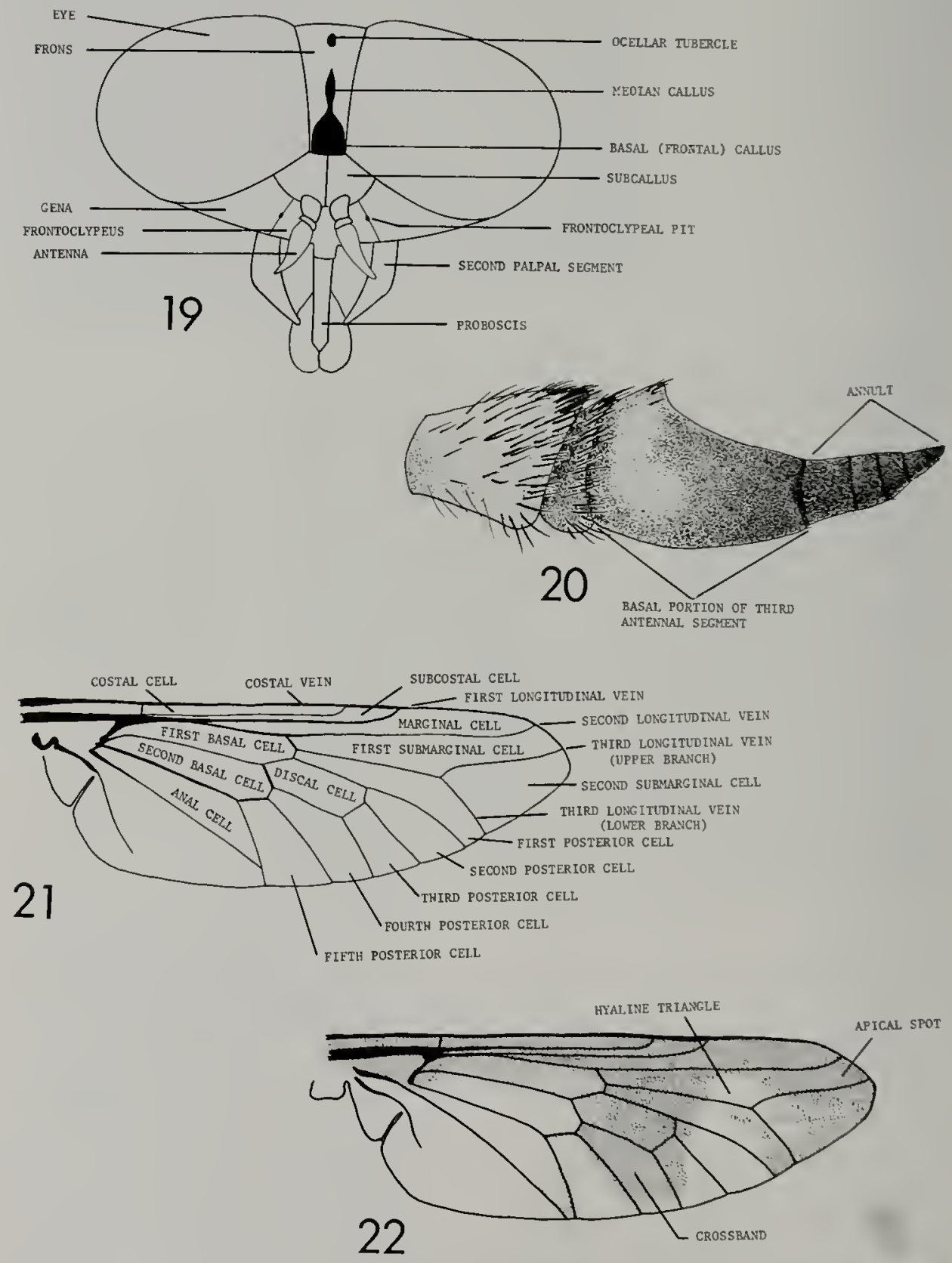

Fig. 19-22.- Head, antenna, wings. 19. Hybomltra lliota, anterior view of head. 20. Hybomitra illota, antenna. 21. Hybomitra illota wing (markings not shown). 22. Chrysops sp. wing. 

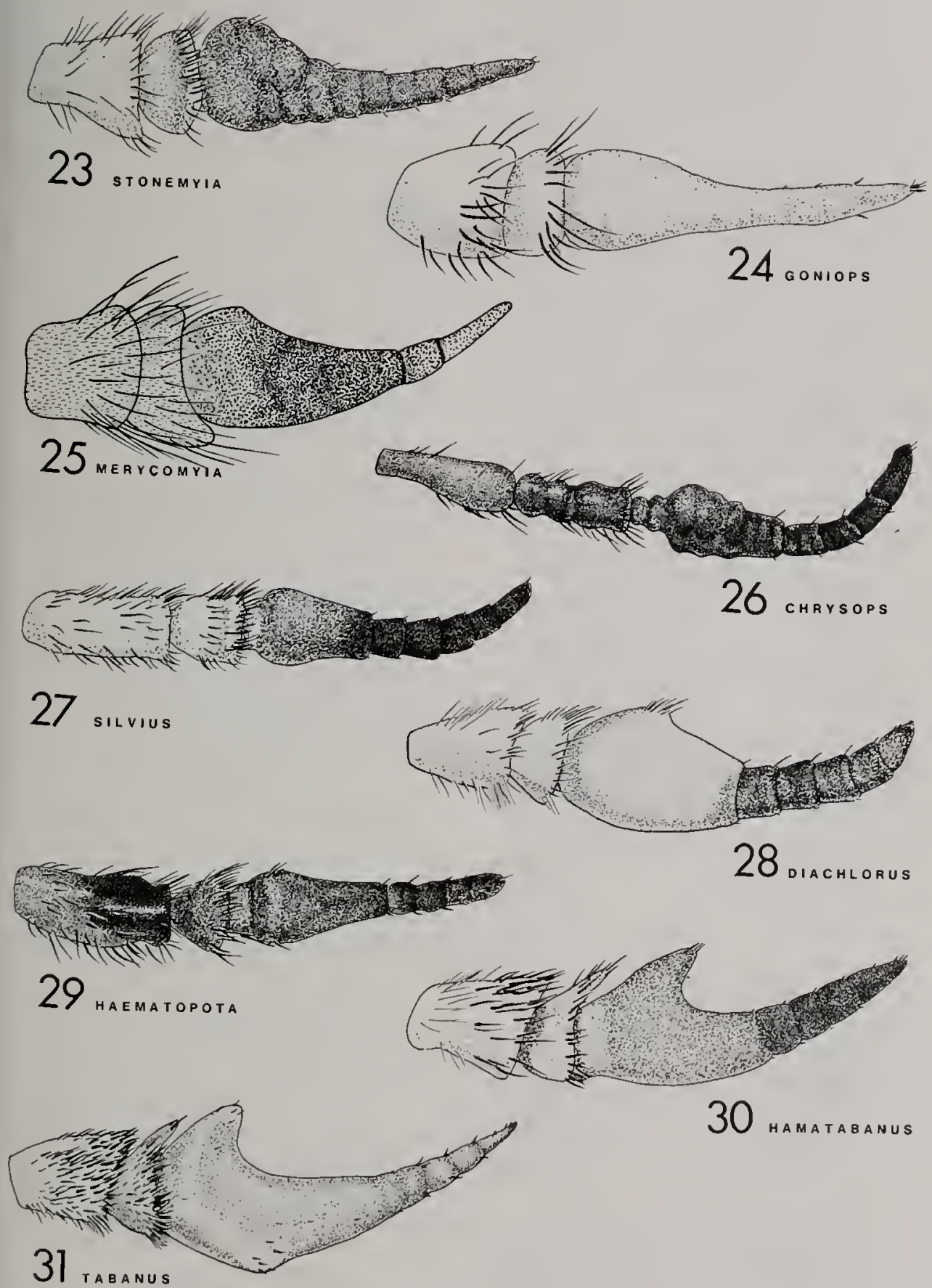

30

HAMATABANUS

Fig. 23-31.-Antennae. 23. Stonemyia. 24. Goniops. 25. Merycomyia. 26. Chrysops. 27 Silvius. 28. Diachlorus. 29. Haematopota. 30. Hamatabanus. 31. Tabanus. 
First antennal segment usually scarcely longer than wide; frons of female higher than broad; wing pattern, if any, not as above

8. Third antennal segment with no dorsal angle (Fig. 28); frons of female narrow, median callus a narrow line; wings with dark pattern (Fig. 75); eyes bare; no ocellar tubercle; fore tibiae swollen; basicosta (subepaulets) bare

Diachlorus

Without this combination of characters ....9

9. Ocelli small but distinct; frons narrow; frontal callus narrow, ridgelike, well removed from eyes ............. Leucotabanus

No ocelli, but ocellar tubercle may be present: frons and callosities, if present, variable but not ridgelike

10. Basicostae (subepaulets) bare or nearly so; abdomen green, unpatterned (pale yellow in older dried specimens): frontal callosities lacking: eyes bare

Chlorotabanus

Basicostae with macrotrichia similar in appearance and density to those on costal vein; abdomen unicolorous or patterned, never green; frontal callosities present or absent; eyes bare or hairy

11. Third antennal segment with hooklike projection from basal plate reaching nearly to base of annulate portion (Fig. 30); eyes sparsely hairy in female, densely haired in male ...... Hamatabanus

Third antennal segment rarely with projection (Fig. 31); if present, eyes bare... 12

12. Vertex with distinct bare ocellar tubercle in female, male with elevated anteriorly shining tubercle: eyes hairy in most species.

Hybomitra

Vertex without ocellar tubercle; if elevated tubercle present in male, then completely pollinose; eyes bare or hairy

13. Frons of female with frontal callosities absent or reduced to 1 or 2 small oval spots well separated from eyes; eyes hairy, heavily so in males, often yellow or pale brown in dried specimens Atylotus

Frons at least with broad basal callus; eyes hairy or bare, usually blackish in dried specimens Tabanus

\section{Larvae}

1. Body pear shaped. Integument opaque and roughened. All segments with an annular ring of small iubercles or crenulate frills (Fig. 81)

Goniops chrysocoma

Body elongate, more or less cylindrical. Integument membranous and transparent, usually with longitudinal striations on some aspect of most segments, or integument entirely covered by short, dense pubescence. Some ab- dominal segments with prolegs (Fig.

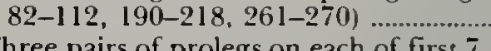

2. Three pairs of prolegs on each of first 7 abdominal segments, a pair dorsally; laterally, and ventrally (Fig. 82-110).....3

Four pairs of prolegs, including an additional ventrolateral pair, on each of first 7 abdominal segments (Fig. 111 , $112 ; 190-218 ; 261-270$ )

3. Body surface, except respiratory siphon, almost or completely covered with a dense, short pubescence.

Body surface with large bare areas: pubescence restricted to anterior or posterior margin or posterior border of prolegs of 1 or more segments......

Chrysops (separate key)

4. Pubescence completely covers body surface, conspicuously mottled with dark and pale areas (Fig. 109). Third antennal segment shorter than second. Respiratory siphon length equal to or only slightly longer than its basal diameter ....Chlorotabanus crepuscularis

Pubescence absent from narrow posterior band on most segments, not conspicuously mottled (Fig. 110). Third antennal segment longer than second segment. Respiratory siphon length about twice as long as its basal diameter ................Diachlorus ferrugatus

5. Respiratory siphon comprises distal ends of 2 opposed sclerotized plates between which tracheal trunks terminate in a protrusile spiracular spine (Fig. 80). Inconspicuous and incomplete striations present only laterally on segments ...........Merycomyia whitneyi

Respiratory siphon always membranous and lacks sclerotized plates, tracheal trunks sometimes terminating in a spiracular spine. Striations present or absent on abdominal segments...............6

6. Respiratory siphon shorter than its basal diameter. Integumental striations extremely fine on all aspects of body; usually visible only under high magnification: striations spaced at approximately $5 \mu \mathrm{m}$................Haematopota rara

If respiratory siphon shorter than its basal diameter, then striations nore widely spaced, usually at more than $20 \mu \mathrm{m}$

7. Respiratory siphon sery short, projecting no more than half its basal diameter. Anal segment usually slorter than its greatest dianeter, hemisplerical (Fig. 111, 112). Striations uniformly spaced on all aspects of body

Respiratory siphon ranges from slightly: shorter (Fig. 196, 197) to about four times longer than its basal diameter. Anal segment usually somewhat attennated posteriorly toward respiratory siphon (Fig. 190-218, 261-270). Striations normally absent from dorsal and 
ventral surfaces of al least prothorax, and more widely spaced dorsally and ventrally than laterally on other segments

8. Pubescence encircles anterior threequarters of prothorax and broadly encircles posterior half of anal segment so that anal ridges and base of respiratory siphon are covered by enlarged pubescent area (Fig. 111). Inhabits wet soil on banks of streams and rivers

\section{Silvius quadrivittatus}

Pubescence encircles little more than anterior quarter of prothorax and restricted to narrow annulus around base of respiratory siphon and vestiture of anal ridges on anal segment so that pubescence on anal ridges is separated from that encircling base of respiratory siphon (Fig. 112). Inhabits decaying wood and tree holes

Leucotabanus annulatus

9. Midlateral surfaces of anal segment lack pubescent markings. Striations present on dorsal and ventral surfaces of all abdominal segments, or if absent, pubescence restricted, at most, to a prothoracic annulus and to the anal ridges Hybomitra (separate key)

Either median lateral surfaces of anal segment with pubescent markings, or striations absent or poorly developed on dorsal or ventral surface or on both surfaces abdominal segments ...

.Tabanus, Atylotus (separate key)

\section{TAXONOMIC TREATMENT}

In this paper a list of the localities where each species in lllinois was collected is omitted. Instead, the lllinois distribution is shown on separate maps for most of the species. Localities are listed for those species collected at five or fewer sites in Illinois. A map of the North American distribution of each species is provided.

In the brief description that precedes the discussion of each species, the average size of individuals is given. Characters given for the male include only those showing obvious differences from those of the female.

\section{Stonemyia Brennan}

The species of this genus are not known to suck blood; they are found on flowers and resting on the ground in openings in wooded areas. None of the species is common. Nothing is known of the biology of Nearctic species.

Until this genus was erected, the species under consideration were placed in various genera, most commonly in Pangonia and Buplex.

\section{KEY TO SPECIES OF STONEMYIA}

1. Yellowish species, including antennae and legs ....................................isabellina

Brown species; abdominal tergites with grayish hind margins. .rasa

\section{Stonemyia isabellina (Wiedemann)}

Silinus isabellina Wiedemann (1828:112).

Type-locality: North America.

Pangonia pigra Osten Sacken (1875:367).

Type-locality: Kentucky, Bee Spring.

Moderate size (12 mm); yellow; wing membrane very faintly tinted, costal cell yellow.

This species was originally described in the genus Silvius and for many years was unrecognized, the specific name pigra being used.

The immature stages of this species are not known.

$S$. isabellina is an eastern species, extending from Georgia to the southern tip of New York and west to western Kentucky (Fig. 32). As yet this species has not been collected in Illinois although specimens have been examined from western Kentucky and Ohio.

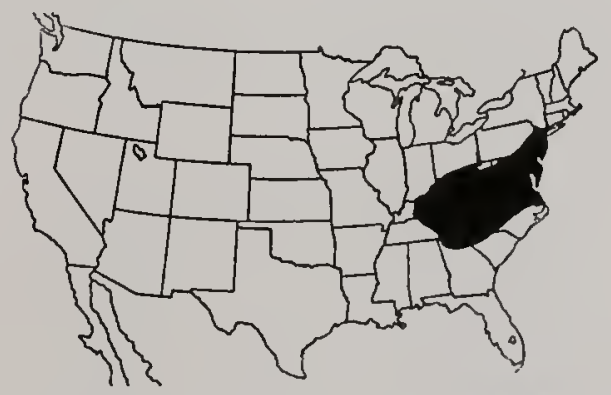

Fig. 32.-Distribution of Stonemyla Isabellina in North America.

\section{Stonemyia rasa (Loew)}

Pangonia rasa Loew (1869:5). Typelocality: northern Wisconsin.

Moderate size $(12.5 \mathrm{~mm})$; dark brown; abdominal tergites with grayish 
hind margins; legs reddish brown; wing membrane faintly tinted, costal cell yellow (Fig. 36).

The immature stages of this species are unknown.

In Illinois adults have been collected from late July to early August.

$S$. rasa is a northeastern species, extending from northern Georgia to southern Quebec and west to Minnesota and Illinois (Fig. 33). In Illinois this species has been collected only in the northern part of the state.

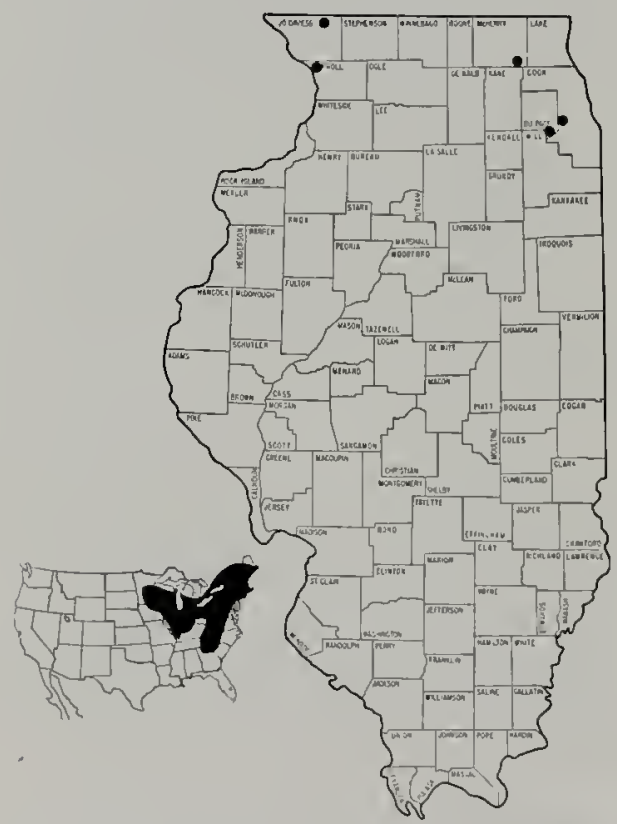

Fig. 33.-Distribution of Stonemyia rasa in Illinois and North America.

\section{Goniops Aldrich \\ Goniops chrysocoma (Osten Sacken)}

Pangonia chrysocoma Osten Sacken (1875:368). Type-locality: New York (lectotype).

Goniops hippoboscoides Aldrich (1892: 237). Type-locality: Pennsylvania, Jeannette.

Stout species (12 mm); yellowish; eyes with upper inner angles acute: frons broader than width of eve; wings (Fig. 37) with dark pattern. Male brownish; abdominal tergites with pale bands on hind margins.
This is the only species in this genus, and neither sex is likely to be confused with any other tabanid. They are stout-bodied insects, $10-15 \mathrm{~mm}$ long, with the fore part of the wings infuscated.

The eggs are laid on the underside of tree leaves above damp ground in wooded areas. The female normally remains with the eggs until they hatch, and when disturbed makes a loud buzzing sound. The larvae (Fig. 81) are found in the lower lavers of deep leaf mold and in damp soil (Pechuman 1972; Teskey 1969).

In Illinois adults appear in early: May and have been collected until early July.

$G$. chrysocoma is a northeastern species, extending from Georgia to Vermont and southwest to Arkansas (Fig. 34). This species has been collected at only three localities in eastern and southern Illinois.

IIlinois records.-Jackson County, Makanda; Pope County, Dixon Springs Agricultural Experiment Station (1.5 miles S Glendale): Vermilion County, Forest Glen Forest Preserve (5 miles SE Westville).

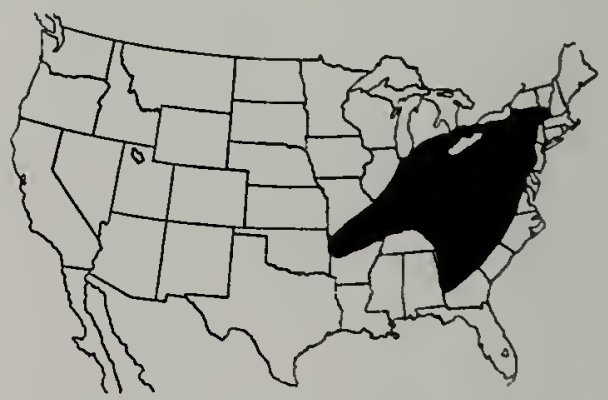

Fig. 34.-Distribution of Goniops chrysocoma in North America.

\section{Merycomyia Hine Merycomyia whitneyi (Johnson)}

Tabanus whitneyi Johnson (1904:15). Type-locality: New York.

Menycomyia mixta Hine (1912:516). Typelocality: Georgia, Bainbridge.

Mencomvia geminata Hine (1912:515). Type-locality: Connecticut, Lyme. 
Large size (2I mm); brownish; first antennal segment only slightly longer than wide (Fig. 25); flagellum with two or three annuli; abdomen with large white patch indented above on fourth tergite, two white spots on fifth tergite; wing membrane tinted with brown, deeper toward front margin, base, and along veins; costal cell yellowish brown; hind tibiae with very small apical spurs. Male easily associated with female.

The larvae have been collected from organic material under a meter of water, from sandy clay mud in the marginal region of a small lake, from moss along the edge of a pool, and from silt along a stream (Pechuman 1972; Teskey 1969; Tidwell 1973).

M. whitneyi is a southeastern species, extending from central Florida to Maine and west to Indiana and Alabama, with a disjunct population in southern Ontario (Fig. 35). As yet this species has not been collected in Illinois although the Indiana record was collected in a county adjacent to Illinois.

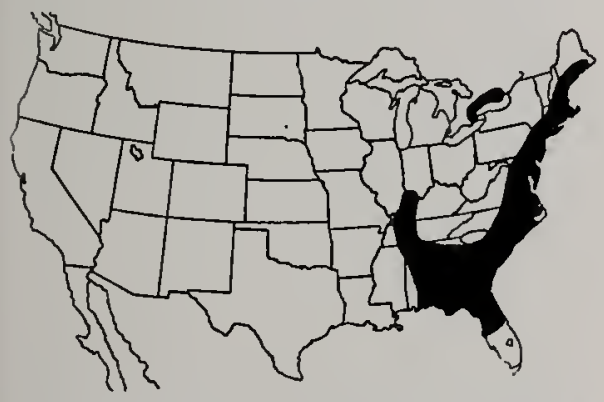

Fig. 35.-Distribution of Merycomyla whitneyi in North America.

\section{Chrysops Meigen}

This genus includes the common deer flies with dark wing markings. The eyes are bright green and gold with dark markings. The bright colors and dark markings disappear from the eyes shortly after death. The deer flies are annoying pests of man but probably are of less importance as pests of livestock than the larger Tabanus and Hybomitra species.

They are most abundant in wooded areas but are also found in many other surroundings. Adult deer llies first appear in early April in Illinois and have been collected until mid-September. The main flight season of each species is short, rarely over 2 weeks; nevertheless, specimens may be found throughout the season.

The males of all species of Chrysops (except C. sequax tau) found or likely to be found in Illinois are known. In several species, however, the male is known from only a single or very few specimens.

To aid in identification, Fig. 38-72 illustrate the wing patterns of the various species of Chrysops found in the central states. All of these wing photographs are of females; all are at the same magnification.

\section{KEY TO SPECIES OF CHRYSOPS}

\section{Fenuales}

1. Apical spot (Fig. 42) dilutely extended around wing reducing hyaline triangle to subhyaline area not reaching hind margin of wing; large brown species; first antennal segment swollen: little or no trace of abdominal markings brunneus

Without this combination of characters ...2

2. Wing pattern exiremely faint, almost obsolete, only costal cell obviously darkened; rather small, dark species. with yellow on abdomen not in form of stripes .................................fulvistigma

Wing pattern distinct even in rare cases where wing membrane tinted rather than hyaline

3. Apex of wing beyond crossband hyaline (Fig. 44) ..................................................t

Apex of wing beyond crossband infuscated, apical spot present (Fig. 50) .....11

4. Second basal cell hyaline (Fig. 44); frontoclypeus without median pollinose stripe

Second basal cell at least half infuscated (Fig. 45); frontoclypeus with median pollinose stripe.

5. Bare integument runs from ocellar area to occiput uninterrupted by pollinese areas; sublateral thoracic stlipes distinct ................................................ calvus

Bare integument of ocellar area interrupted by pollinose band; sublateral thoracic stripes indistinct ................ niger

6. Abdomen entirely dark, sometimes with inclefinite pattern of grayish pollinose areas

1


Abdomen with pale areas on at least first 2 abdominal segments.

7. Fifth posterior cell with hyaline area at base (Fig. 45)

Fifth posterior cell infuscated at base (Fig. 47)

8. Crossband reaches hind margin of wing rather broadly, outer margin quite straight or slightly bowed (Fig 45); hyaline spot at base of fifth posterior cell large, distinct carbonarius

Crossband usually not broadly reaching hind margin of wing, outer margin irregular (Fig. 40); hyaline spot at base of fifth posterior cell usually not clear-cut, sometimes almost obsolete ...ater

9. Pleura with yellow to orange-red pile; crossband broadly reaches hind margin of wing (Fig. 47). cincticornis

Pleura with grayish or pale yellowish pile; crossband narrowly or not reaching hind margin of wing (Fig. 59)

mitis

10. Wing picture pale (Fig. 48); pleura with gray pile; no median abdominal triangle (occasional specimens of $C$. mitis have small reddish spots laterally at base of abdomen but wing picture is dark). cuclux

Wing picture dark (Fig. 51); pleura with yellow or orange pile; median abdominal triangle present. excitans

11. Frontoclypeus with pollinose stripe or projection below antennae ...................12

Frontoclypeus without pollinose stripe or projection.

12. Abdomen completely black ..........separatus

Abdomen with yellow and black pattern

13. First basal and costal cells lightly infuscated to nearly hyaline (Fig. 71); abdomen black with middorsal yellow stripe, often shorter lateral stripes upsilon (in part)

First basal and costal cells heavily infuscated (Fig. 53); abdomen yellow with black pattern

14. Frontoclypeus black, rarely yellow; abdominal markings not in form of stripes. frigidus

Frontoclypeus yellow; abdomen with 4 black stripes. sequax tau

15. First basal cell completely infuscated (Fig. 57), rarely subhyaline toward apex

First basal cell always at least half hyaline, sometimes almost entirely so.......26

16. Wing pattern pale buffy brown (Fig. 57); first hasal cell subhyaline toward apex; wing membrane tinted; hraline triangle nearly reaches second longi- tudinal vein; apical spot narrow; entering only upper corner of second submarginal cell Iuteopennis

Wing pattern dark brown to black (Fig. 60 ); apical spot broad, occupving nearly half to all of second submarginal cell.

17. Hyaline triangle small but clear, distinct, restricted to apices of second and third posterior cells (Fig. 60) ....moechus

Hyaline triangle extends toward costal margin beyond second posterior cell (Fig. 41)

18. Hyaline triangle reaches and sometimes crosses second longitudinal vein, sometimes upper portion tinted so that it is indistinct, often narrow and crescent shaped (Fig. 41).

Hyaline triangle does not extend much beyond bifurcation, not crescent shaped

19. Frontal callus yellow beameri

Frontal callus black or deep brown ........20

20. Yellowish species with abdomen conspicuously black striped..

Fuscous species; abdomen with pale median line, occasionally traces of pale lateral lines dacne

21. Abdomen with 2 prominent submedian black stripes; sublateral stripes absent on tergites 1 and 2, sometimes 3; hyaline triangle rounded at apex (Fig. 63) pikei

Abdomen with + complete black stripes; hyaline triangle pointed apically (Fig. 68) sequax sequax

22. Abdomen with 4, more or less complete. dark longitudinal stripes

Abdomen not striped or with fewer than 4 stripes

23. Most of fifth posterior cell infuscated (Fig. 72); scutellum yellow vittatus

Fifth posterior cell almost entirely hyaline (Fig. 38); scutellum dark, with or without paler apex and/or sides.....24

24. Apical spot nearly fills second submarginal cell (Fig. 38); abdomen with 2 central stripes, rarely joined on second segment: frontal callus usually yellow: sometimes brown or black.....

\section{aberrans}

Apical spot only half fills second submarginal cell (Fig. (i9); abdomen with 2 central stripes. usually joined on second segment: fromtal callus ustually black. sometimes brownisl, rarely vellowish striatus

25. Apical spot fills most of second submarginal cell, extends into first and sometimes second posterior cell, is usually connected with crossband by 
streak of infuscation in first posterior cell (Fig. 58); abdomen with 2 stripes, sometimes reduced to faint lines or enlarged to cover most of abdomen on each side of yellow stripe; scutellum usually with considerable yellow ........................................macquarti

Apical spot fills only about half of second submarginal cell, does not extend farther (Fig. 56); abdomen not striped; scutellum dark indus

26(15). Apical spot narrow, including at most only extreme apex of second submarginal cell (Fig. 66)

Apical spot broad, entering second submarginal cell over at least onethird of upper branch of third longitudinal vein (Fig. 70)

27. Apical spot, just beyond where it leaves crossband, slightly wider than marginal cell (Fig. 66): frontal callus usually yellow, often bordered with black or brown, occasionally black ......28

Apical spot at base narrower than or just as wide as marginal cell (Fig. 39); frontal callus normally black

28. Second abdominal segment with black spot almost joining that on first segment; second and third sternites with black sublateral spots; robust species sackeni

Second abdominal segment with black spot usually not attaining anterior margin of segment, second and third sternites without sublateral spots; more slender species .... pudicus (in part)

29. Apical spot very narrow, more dilute than crossband (Fig. 39); front little convergent at vertex. Abdomen with pale markings usually grayish or dull yellow; second abdominal segment with black triangles, one on each side of dark median marking, triangles may or may not be connected with latter by dark band along posterior margin of segment. aestuans

Apical spot varies from one-half to full width of marginal cell, same density as crossband (Fig. 43); front somewhat convergent at vertex. Abdomen with pale yellow markings, often quite bright; second abdominal segment with dark median marking which may have projections along posterior margin of segment that do not form lateral triangles callidus

30. Blackish species with middorsal yellow (occasionally grayish) abdominal stripe, often with shorter sublateral stripes ....3!

Abdomen with different pattern, showing more yellow .32

31. Infuscation of costal cell distinctly paler than crossband (Fig. 71): apical spot often nearly fills second submarginal cell...................................upsilon (in part)

Costal cell same color as crossband (Fig. 70); apical spot variable but rarely fills more than half of second submarginal cell . univittatus

32. Hyaline triangle distinctly crosses second longitudinal vein, nearly separating apical spot from crossband (Fig. 54)......33

Hyaline triangle, at most, reaches second longitudinal vein (Fig. 61)

33. Second abdominal segment with black inverted $\mathrm{V}$ or pair of oblique spots

Second abdominal segment entirely
yellow............................................mpunctus

34. Abdomen with 4 rows of spots, but lateral spots on second segment may be reduced or absent; median figure on second abdominal segment an inverted $V$; scutellum and frontal callus normally dark, but latter sometimes brownish montanus

Abdomen normally without 4 rows of spots

35. Hyaline triangle reaches second longitudinal vein (Fig. 64)....pudicus (in part)

Hyaline triangle does not reach second longitudinal vein (Fig. 50) ...................36

36. Abdominal markings black, median marking of second segment usually reaches anterior margin; frontal callus normally black, sometimes yellow; usually at least basal portion of hind femora black. dimmocki

Abdominal markings brown, often quite pale, median marking of second abdominal segment rarely attains anterior margin; frontal callus yellow; hind femora yellow, pale brown, or mahogany

37. Thorax greenish gray wilh fuscous stripes; outer margin of crossband sinuous (Fig. 46) celatus

Thorax yellow brown with dark brown stripes: outer margin of crossband concave, straight, or sinuous.................38

38. Second abdominal segment with dark median marking, reaching only about halfway across segment, leaving an anterior greenish yellow area; outer margin of crossband sinuous (Fig. 65): legs ustally rather uniform mahogany color ............................reicherti

Second abdominal segment will dark median marking, reaching across about two-thirds of segment, pale anterior area without greenish tinge; outer margin of crossband usually straiglit or somewhat concave (Fig. 52); legs yellow or pale brownish flavidus 

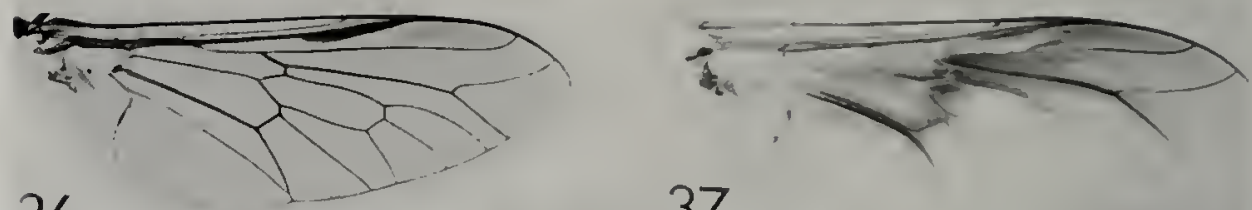

36

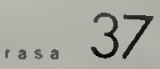

chrysocoma

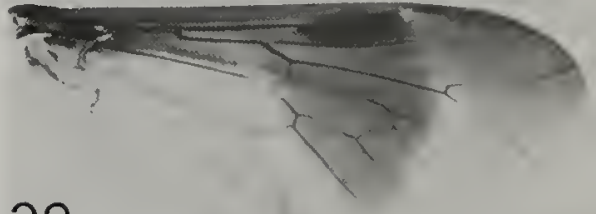

38

soerrons 39
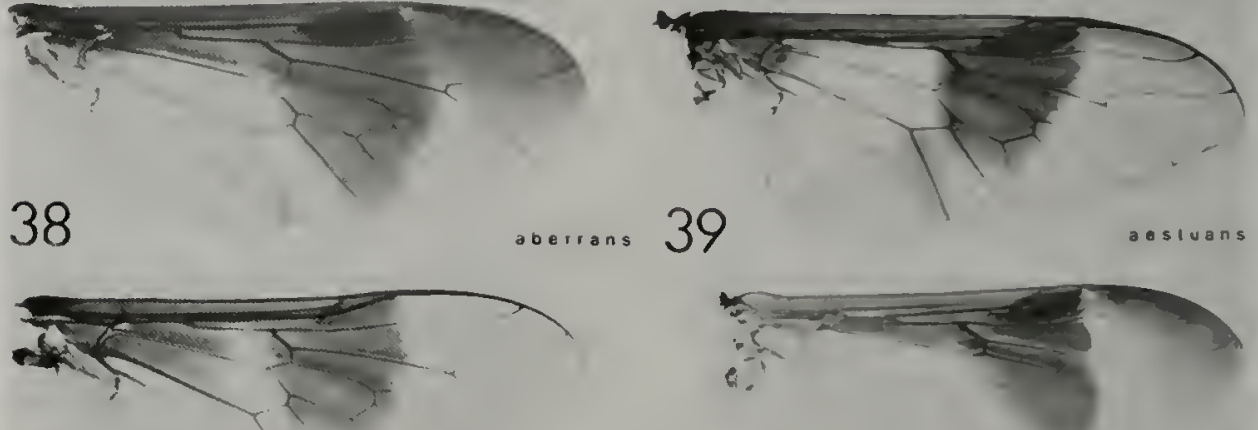

40

.1e, 41
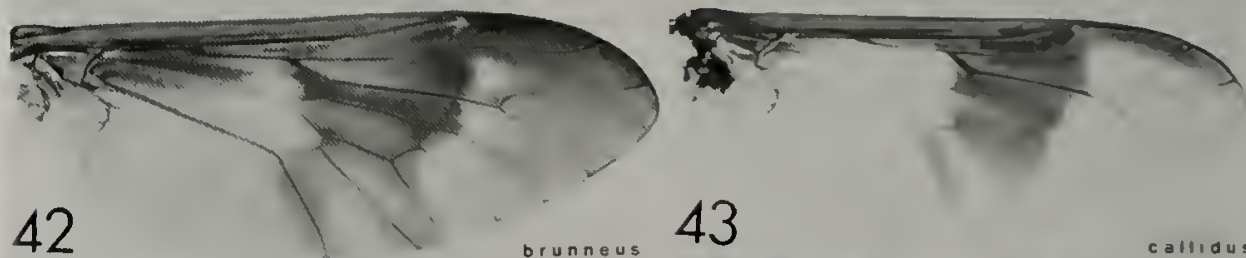

43
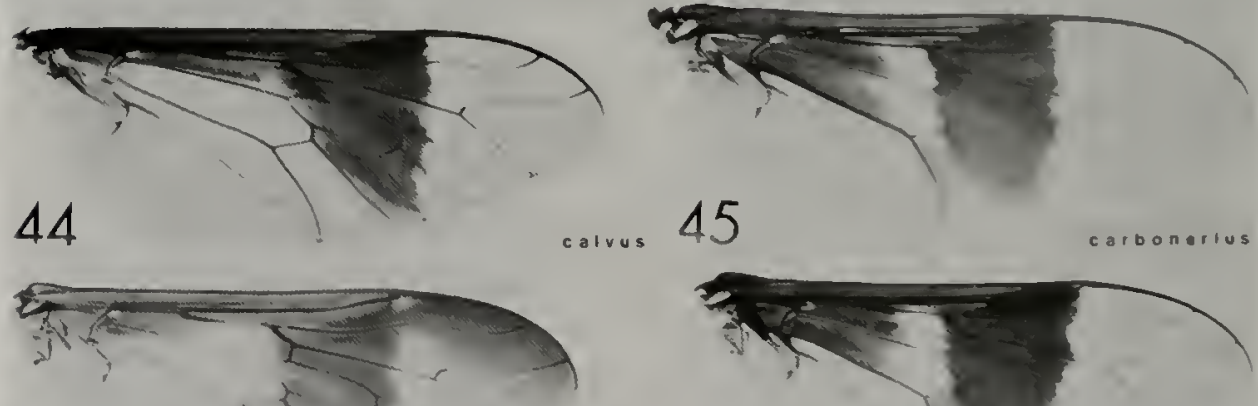

46

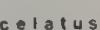

47
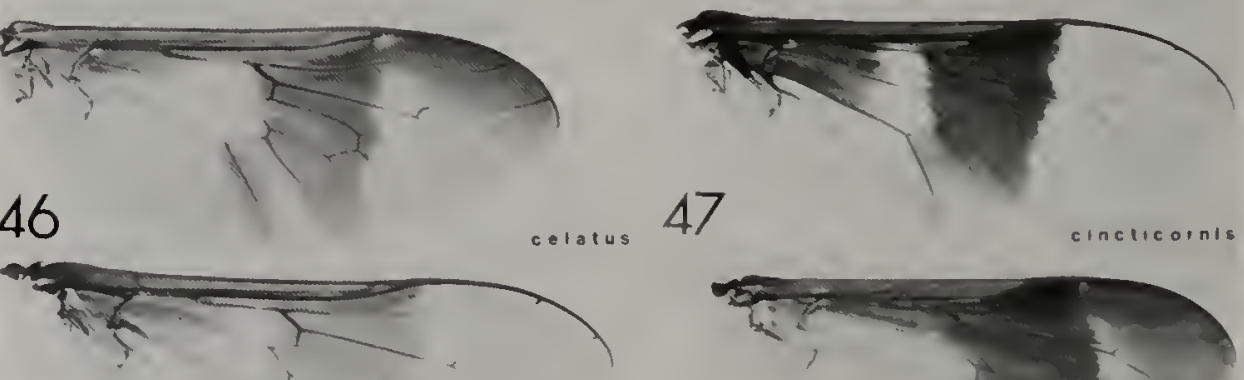

48

49

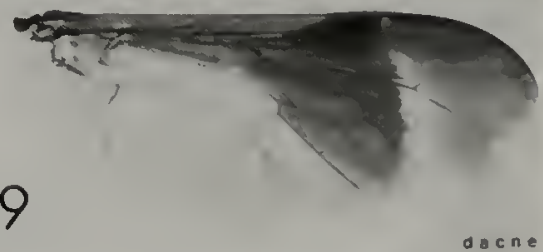

Fig. 36-49.-Wing patterns. 36. Stonemyia rasa. 37. Gonlops chrysocoma. 38. Chrysops aberrans. 39. C. aestuans. 40. C. ater. 41 . C. beamerl. 42. C. brunneus. 43. C. callidus. 44. C. calvus. 45 . C. carbonarlus. 46 . C. celatus. 47 . C. cincticornls. 48 . C. cuclux. 49 . C. dacne. 

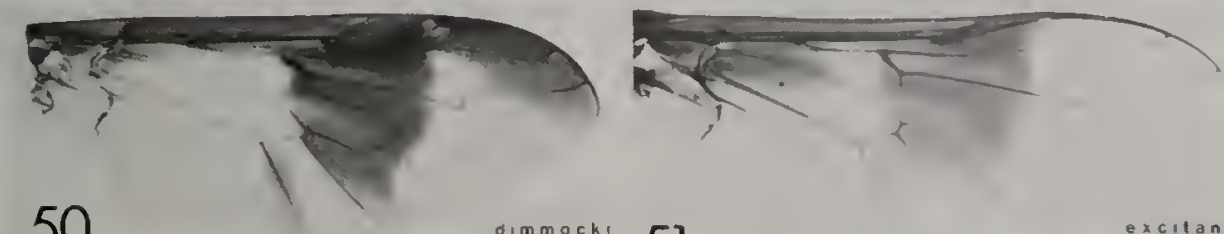

\section{0}

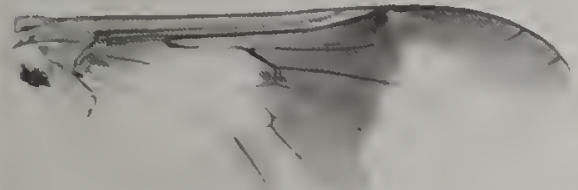

52

navious 53

51

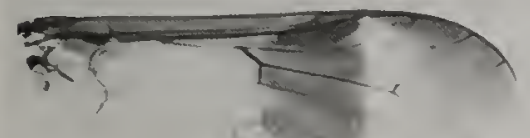

54

sectionsus 55

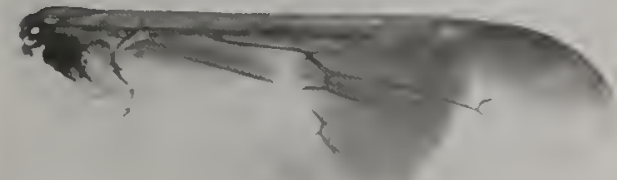

56

inous
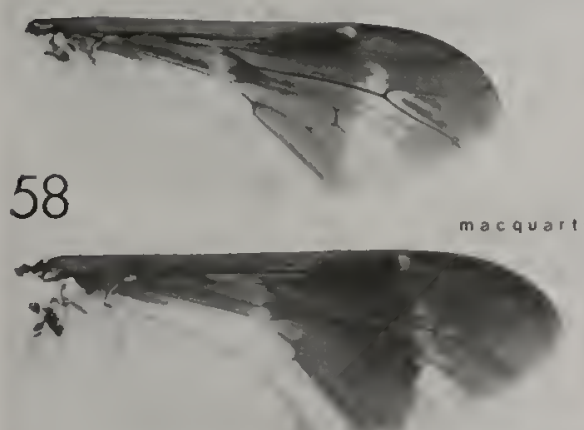

60

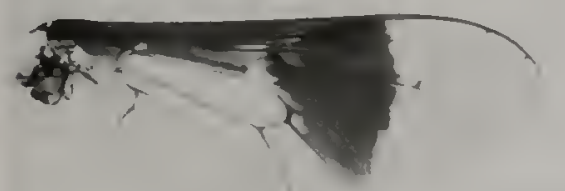
62
niger
63

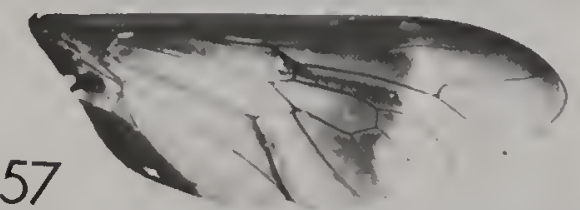

Iuteopennis
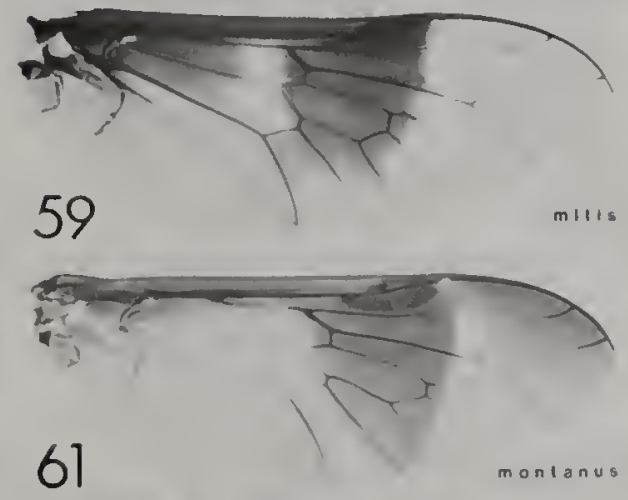

Fig. 50-63.-Wing patterns. 50. Chrysops dimmocki. 51. C. excitans. 52. C. fiavidus. 53 . C. trigidus. 54. C. geminatus. 55. C. impunctus. 56. C. Indus. 57. C. luteopennis. 58. C. macquarti. 59. C. mitis. 60 . C. moechus. 61 . C. montanus. 62. C. niger. 63. C. pikel. 

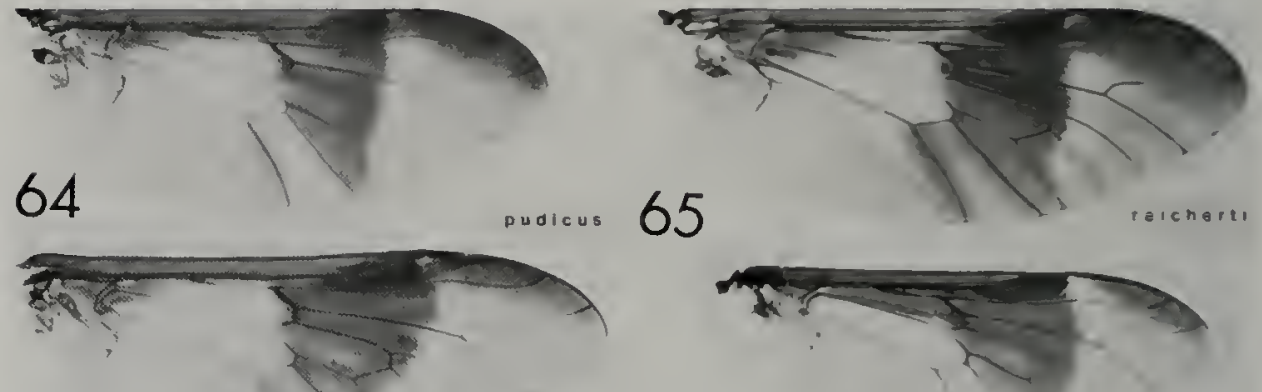

66

socken 67

separatus

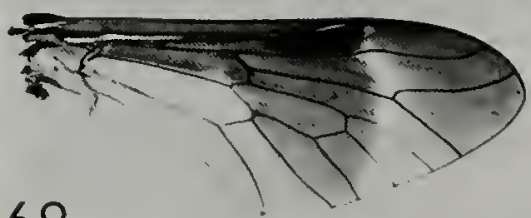

68

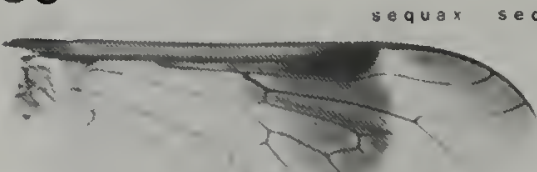

69

stiflas

70

univitatus

71
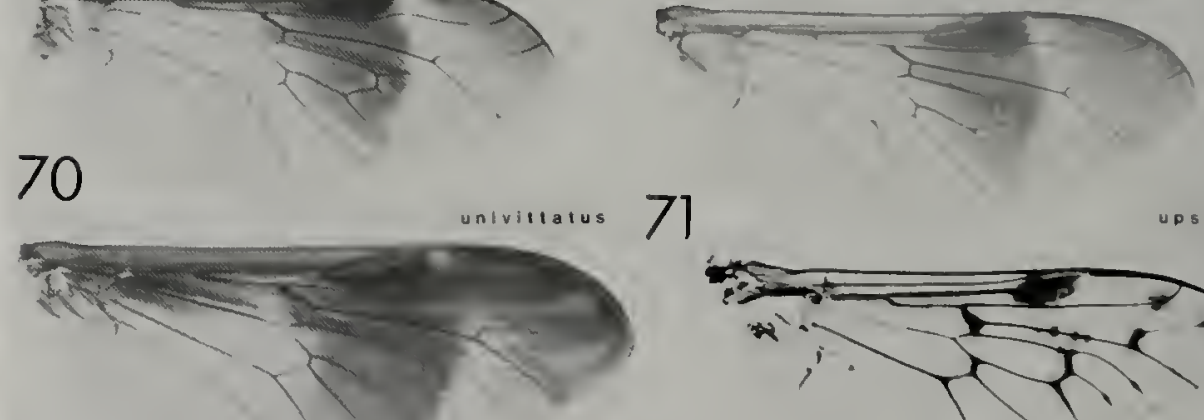

72

viltatus

73
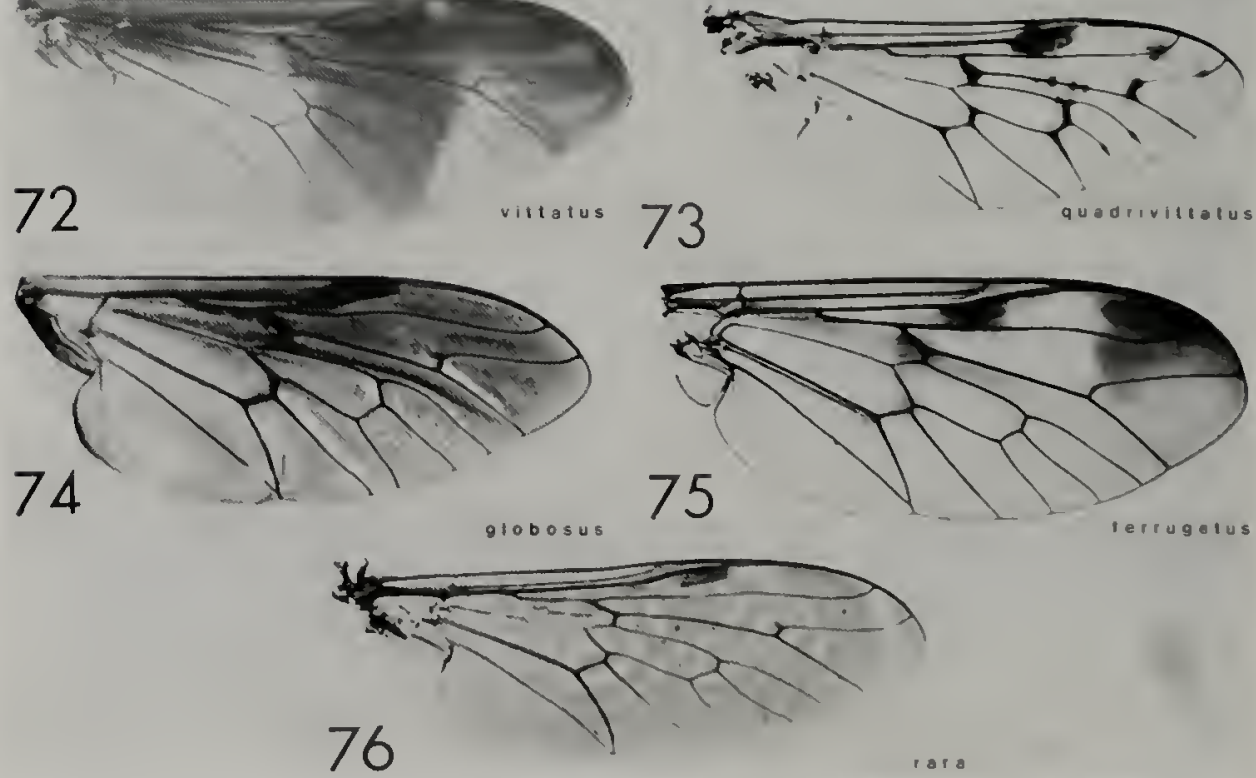

Fig. 64-76.-Wing patterns. 64. Chrysops pudicus. 65. C. reicherti. 66. C. sackeni. 67. C. separatus. 68 . C. sequax sequax. 69 . C. striatus. 70 . C. univittatus. 71 . C. upsilon. 72 . C. vittatus. 73 . Silvius quadrivittatus. 74 . Neochrysops globosus. 75 . Diachlorus ferrugatus. 76 . Haematopota rara. 


\section{Males}

1. Wing pictures pale brown to evanescent yellow: frontoclypeus with pollinose iriangle or pollinose stripe below antennae.

Wing picture dark brown to black, usually latter; frontoclypev's with or without pollen (if large species with brown wing pattern, swollen scapes, and indefinite abdominal pattern, see couplet 16).

2. Wing with obvious apical spot; frontoclypeus yellow with pollinose area in form of equilateral triangle below antennae ................................ Iuteopennis

If apical spot present, it is fine line along costal border or an indefinite darkening of apical area; frontoclypeus black with pollen in form of stripe.

3. Wing pattern distinct; abdomen with pale area restricted to lateral margins of first 2 tergites; legs black..........cuclux

Wing pattern very faint; abdomen with yellow sublateral and median spots on first 2 tergites; first 2 sternites mostly yellow: legs with considerable yellow

4. Apex of wing beyond crossband hyaline fulvistigma sometimes with vague cloud.

Apex of wing infuscated beyond crossband so that apical spot present ... .5

5. Frontodypeus wholly black with midfacial pollinose stripe, which begins below antennac runs at least halfway to oral margin

Frontoclypeus mostly yellow without midfacial pollinose stripe

Abdomen completely black ........................ 7

First 2 abdominal segments with small reddish or yellowish spots sublaterally excitans (in part)

7. Fifth posterior cell with hyaline area at base ............................................................8

Fifth posterior cell infuscated at base ......9

8. Outer margin of crossband straight or slightly evenly bowed: crossband usually reaches hind margin of wing in fourth and fifth posterior cells in full intensity; hyaline area at base of fifth posterior cell large, sharply defined. carbonarius

Outer margin of crossband usually bowed or irregular; crossband does not usually reach wing margin in full intensity; hyaline area at base of fifth posterior cell without clearly defined margin; apical area of wing sometimes dilutely infuscated .......................ater

9. Crossband broad, distinctly reaches hind margin of wing; outer margin of crossband usually straight cincticornis

Crossband narrow, does not reach or indistinctly reaches hind margin of wing; outer margin of crossband usually irregular ..........................................10

10. Beard with many yellow hairs; yellow hairs frequently mixed with black hairs of thorax, legs, and abdomen; sometimes with traces of abdominal markings ......................excitans (in part)

Beard wholly black; rarely with pale hairs on body or traces of pale abdominal nuakings mitis

11. Thoracic stripes, especially sublateral ones, fairly distinct, rarely with spot at bifurcation of third longitudinal vein calvus

Thoracic stripes obsolete; often with spot at bifurcation of third longitudinal vein. niger

12. Frontoclypeus with midfacial pollinose stripe...

Frontoclypeus without such stripe............. 15

13. Abdomen entirely black ................separatus

Abdomen with pale markings .................14

14. Abdomen black with narrow yellowish middorsal line, occasionally similar shorter sublateral lines; hyaline triangle approaches costal margin at least as subhyaline streak ...........upsilon

Abdomen otherwise marked, often with considerable yellow; hyaline triangle does not reach beyond bifurcation ....

frigidus

15. Abdomen completely black; hyaline triangle restricted to apices of second and third posterior cells ............moechus

Abdomen not wholly black: hyaline triangle not as above..

16. Brown species with no definite abdominal pattern although dark markings may be indicated by dark shadows; hyaline triangle indicated by clear area along edge of crossband, does not usually extend beyond center of third posterior cell; first antennal segment considerably swollen

brunneus

Blackish or yellowish species; wing pattern clear-cut; hyaline triangle open at hind margin of wing: if otherwise, first antennal segnuent not swollen ..... 17

17. Black species; abdomen with yellowish median longitudinal stripe, occasionally with similar abbreviated stripe on each side; hyaline triangle crosses second longitudinal vein; apical spot rarely nccupies more than hall of second subnarginal cell, often less... univittatus

Without above combination of characters ....................................................... 18

18. Apical spot very little broader at apex than at origin, crnssing upper branch ol third longitudinal vein at apex, occupying very litele of second submirginal cell .. 
Apical spot considerably broadened toward apex, crossing at least half of upper branch of third longitudinal vein

19. Hyaline triangle does not reach second longitudinal vein ..sackeni

Hyaline triangle reaches or crosses second longitudinal vein

20. Second abdominal segment with sublateral black triangles which join median figure along posterior border of segment: fourth posterior cell usually hyaline at apex, fifth posterior cell with considerable infuscation. especially basally; pale markings grayish yellow: apical spot very narrow....aestuans

Second abdominal segment without sublateral black triangles: fourth posterior cell usually entirely infuscated. fifth posterior cell often mostly hyaline: pale markings yellow .............allidus

21. Abdomen yellow and black: large black figure of second abdominal segment broadly joined to black figure of first segment; median yellow markings on tergites 3 and 4 do not reach anterior border of segments; apical spot occupies one-half to two-thirds of second submarginal cell

Without above combination of characters

22. Fore coxae black; hyaline triangle does not reach beyond bifurcation ........indus

Fore coxae yellow: hyaline triangle extends beyond bifurcation......

23. Abdomen with 4 rows of black spots, middorsal rows joining anteriorly on segnents 2-4; apical spot fills about half of second submarginal cell.

montanus

Abdominal pattern not in form of rows or spots dimmocki

24. Apical spot fills half or less of second submarginal cell .......................................2

Apical spot fills all or nearly all of second submarginal cell, sometines extending into first posterior cell or beyond

25. Thorax yellow in ground color with brown stripes; legs yellow ............flavidus

Thorax greenish gray with fuscous stripes; legs variable ......................pudicus

26. Outer margin of crossband sinuous; apical spot nearly surrounds liyaline triangle: basal half of first posterior cell and basal third of second basal cell infuscated; base of second abdominal segment often with greenish cast; legs pale mahogany: thorax ground color brownish ............... reicherti

Without above combination of characters

27. Basal cells never more than hall infuscated, often almost entirely hya- line .28

At least first basal cell more than half infuscated, often entirely so ..................30

28. Hyaline triangle does not cross second longitudinal vein ... celatus

Hyaline triangle crosses second longitudinal vein

29. Second abdominal segment with 2 oblique spots, frequently joined to form inverted $\mathrm{V}$ in center of segment geminatus

Second abdominal segment completely yellow or with traces of dark mark. ings at posterior margin ..........impunctus

30. Hyaline triangle reaches or nearly reaches second longitudinal vein (if subhyaline beyond bifurcation of third longitudinal vein, predominantJy black species with pale abdominal markings reduced)

Hyaline triangle scarcely extends beyond bifurcation of third longitudinal vein; predominantly yellowish species with dark abdominal markings

31. Blackish species with reduced pale abdominal markings ............................dacne

Yellow species with black abdominal markings 32

32. Frontoclypeus and cheeks mostly yellow: second basal cell hyaline ..............beameri

Frontoclypeus with large black spot on each side, cheeks with considerable black: second basal cell at least party infuscated

33. No sublateral spots on first and second abdominal tergites; second basal cell rarely more than half infuscated: hyaline triangle rounded at apex ...........pikei

Sublateral stripes cross first 2 abdominal tergites; second basal cell largely infuscated with subhvaline area near apex: hyaline triangle pointed at apex ................................................ sequax

34. Abdomen with median yellow stripe, longitudinal black band on each side; lateral margins of segments narrowly yellow macquarti

Abdomen yellow with 4 more or less complete rows of black spots . .35

35. Fround color of thorax and scutellum yellow; fifth posterior cell heavil infuscated with hvaline area at base..... ...vittatus

Ground color of thorax gravish olive. scutellum sometimes with some vellow: fifth posterior cell usually hyaline or sublyaline, sometimes infuscated ..36

36. Apical spot completel! fills second submarginal cell: sublateral rows of abdominal spots about as dark as median rows .......................................aberrans

Apical spot does not completely lill second submarginal cell: sublateral 
rows of abdominal spots paler than median rows striatus

\section{Larvae}

1. Respiratory spine absent (Fig. 82-90) ......2 Respiratory spine present (Fig. 78, 91108)

2. Pubescence diffusely covers all of last 3 or 4 segments, but densest near their midlengths. Larva very slender, with long prolegs. Respiratory siphon approximately five times as long as its basal diameter (Fig. 82) .............moechus

Distinct nonpubescent areas on last 3 segments. Respiratory siphon no more than lour times as long as its basal dianeter

3. Anterior pubescent annulion prothorax and mesothorax broad, covering at least one-half and one-third lengths of segments, respectively, without posterior projections (Fig. 83-85)

Thoracic annuli narrower, usually with posterior projections although these may be short (Fig. 86-90) .....................

4. Lateral pubescent projections from prothoracic annulus expanded apically (Fig. 86-88). Living larva greenish .......5

Lateral pubescent projections from prothoracic annulus, if present, tapered (Fig. 89, 90), Living larva usually creamy white

5. Posterior pubescence on preanal segment separated into dorsal and ventral portions, dorsal portion connected by narrow strip to adjacent proleg pubescerice. Proleg pubescence encircles at least first 4 abdominal segments (Fig. 86. 87)

Posterior pubescence encircles preanal segment but not connected to adjacent proleg pubescence (although slight projections from posterior and proleg pubescence dorsolaterally on this segment suggest an ancestral connection). Proleg pubescence restricted to border of dorsal prolegs on all but first ahdominal segment (Fig. 88).......ater

6. Proleg and posterior pubescences on preanal segment broadly connected dorsolaterally, leaving only small dorsal area clear. Similar but narrower connections usually present ventrolaterally on this segment and dorsolaterally on preceding ninth segment (Fig. 86) cuclux

Proleg and posterior pubescences narrowly connected only dorsolaterally on preanal segment (Fig. 87)

carbonarius

7. Pubescent projections from thoracic annuli absent. Proleg and posterior pubescent annuli on preanal segment with narrow connections dorsolateral- ly. Pubescence encircles posterior 1 wothirds of anal segment, broadly connecied to pubescence on anal ridges (Fig. 89) macquarti

Pubescent projections from thoracic annuli present though olten short and inconspicuous. Proleg and posterior pubescences on preanal segment essentially absent. Posterior pubescence absent from anal segment (Fig. 90). frigidus

8. Striations absent laterally on all segments geminatus

Striations present laterally on all segments

9. Anterior pubescence encircles first 3 or 4 abdominal segments. Posterior pubescent annulus on anal segment with dorsolateral and lateral pointed projections from its anterior margin on each side, sometimes with small isolated spot between and anterior to these projections (Fig. 85) ............vittatus

Anıerior pubescence encircles only first abdominal segment, interrupted at least laterally on remainder. Posterior annulus on anal segment with only dorsolateral pointed projections and somewhat jsolated pubescent spot anteroventral to this projection (Fig. 84)

10. Preanal segment with proleg and posterior pubescences broadly joined dorsally, ventrally, and laterally, leaving small clear areas only dorsolaterally and ventrolaterally (Fig. 91)

montanus

Preanal segment with proleg and posterior pubescences not joined.

11. Anterior pubescent annuli on pro- and mesothorax wide, covering approximately one-half to one-1hird length of segments; prothoracic annulus lacks posterior pubescent projections (Fig. 92-94).

Anterior pubescent annuli on thoracic segments narrower with posterior pubescent projections laterally (Fig. 9598)

12. Posterior pubescence encircles seventh abdominal segment. Anterior pubescence encircles first 5 abdominal segments (Fig. 92) ........................sequax

Posterior pubescence either absent on seventh abdominal segment or restricted to small lateral spot. Anterior pubescence encircles no more than first abdominal segment .......................13

13. Pubescence present, though very pale, on anterior margin of first 7 abdominal segments (Fig. 93) ......................niger

Pubescence absent from first 7 abdominal segments (Fig. 94) ...........calvus 

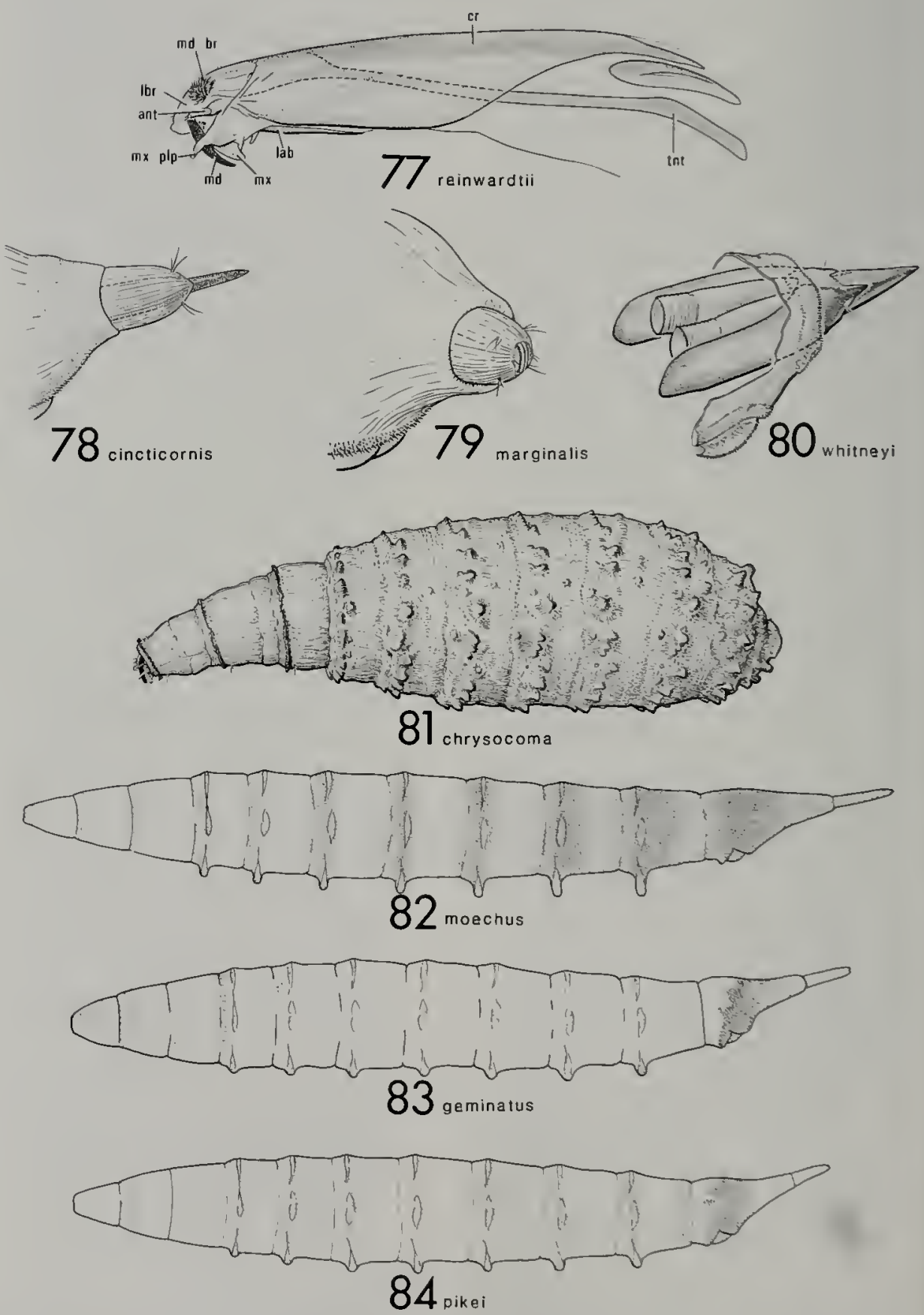

Fig. 77-84.- Head capsule. 77. Tabanus reinwardtil. Respiratory siphons. 78 . Chrysops cincticomis. 79. Tabanus marginalls. 80 . Merycomyla whitneyi. Larva. 81. Goniops chrysocoma. 82. Chrysops moechus. 83. C. geminatus. 84. C. pikel. Abbreviations: ant, antenna; cr, cranium; lab, labium; lbr; labrum; $m d$, mandible; $m d \mathrm{br}$, mandibular brush; $m x$, maxilla; $m x$ plp, maxillary palp; tnt, tentorial arm. 

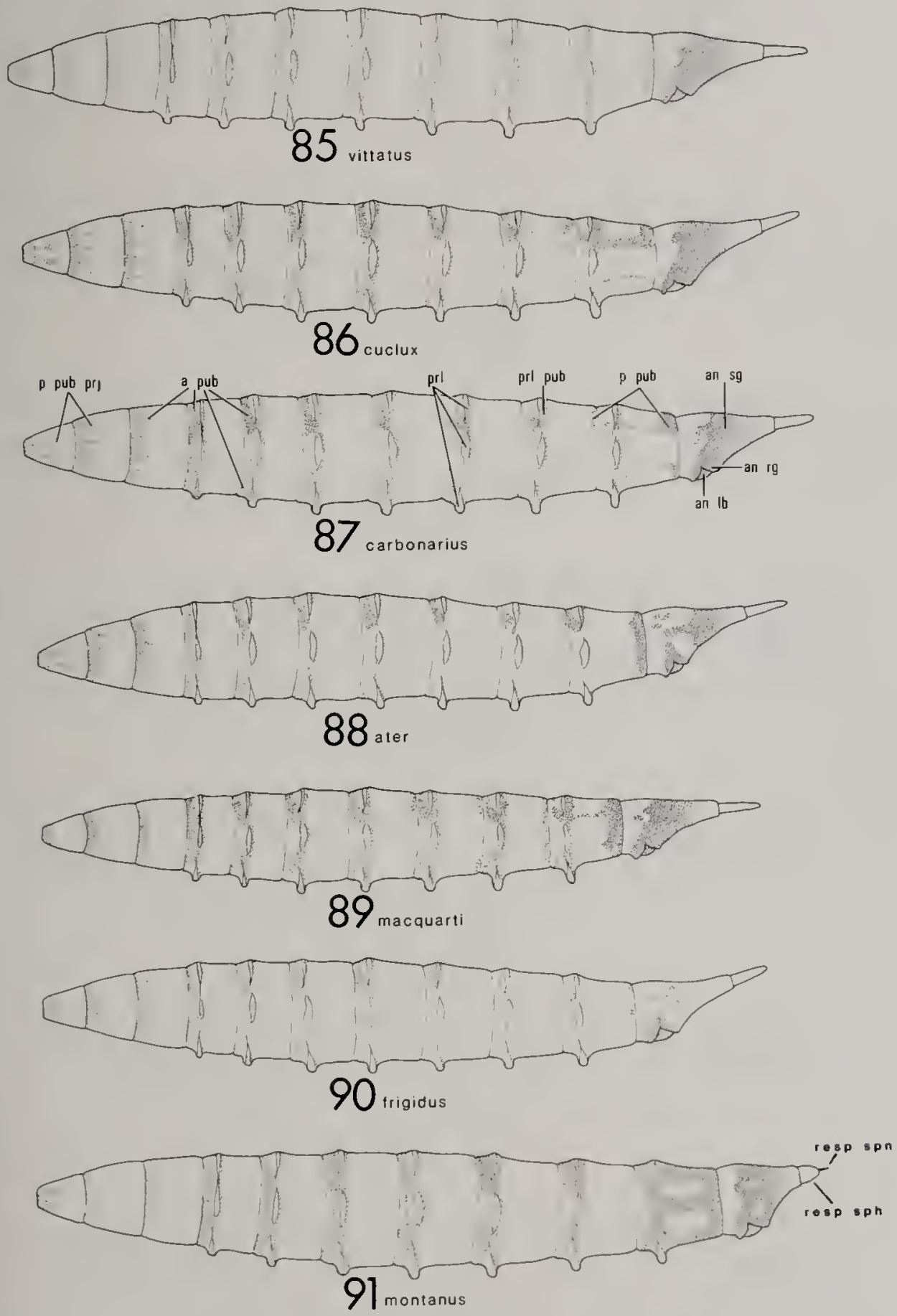

Fig. 85-91,-Larvae. 85. Chrysops vittatus. 86. C. cuclux. 87. C. carbonarlus. 88. C. ater. 89. C. macquarti. 90. C. frigidus. 91. C. montanus. Abbreviations: a pub, anterior pubescence; an sg, anal segment; an $\mathrm{lb}$, anal lobe; an $\mathrm{rg}$, anal ridge; $\mathrm{p}$ pub, posterior pubescence; $\mathrm{p}$ pub $\mathrm{prj}$, posterior pubescent projection; prl, proleg; prl pub, proleg pubescence; resp sph, respiratory siphon; resp spn, respiratory spine. 

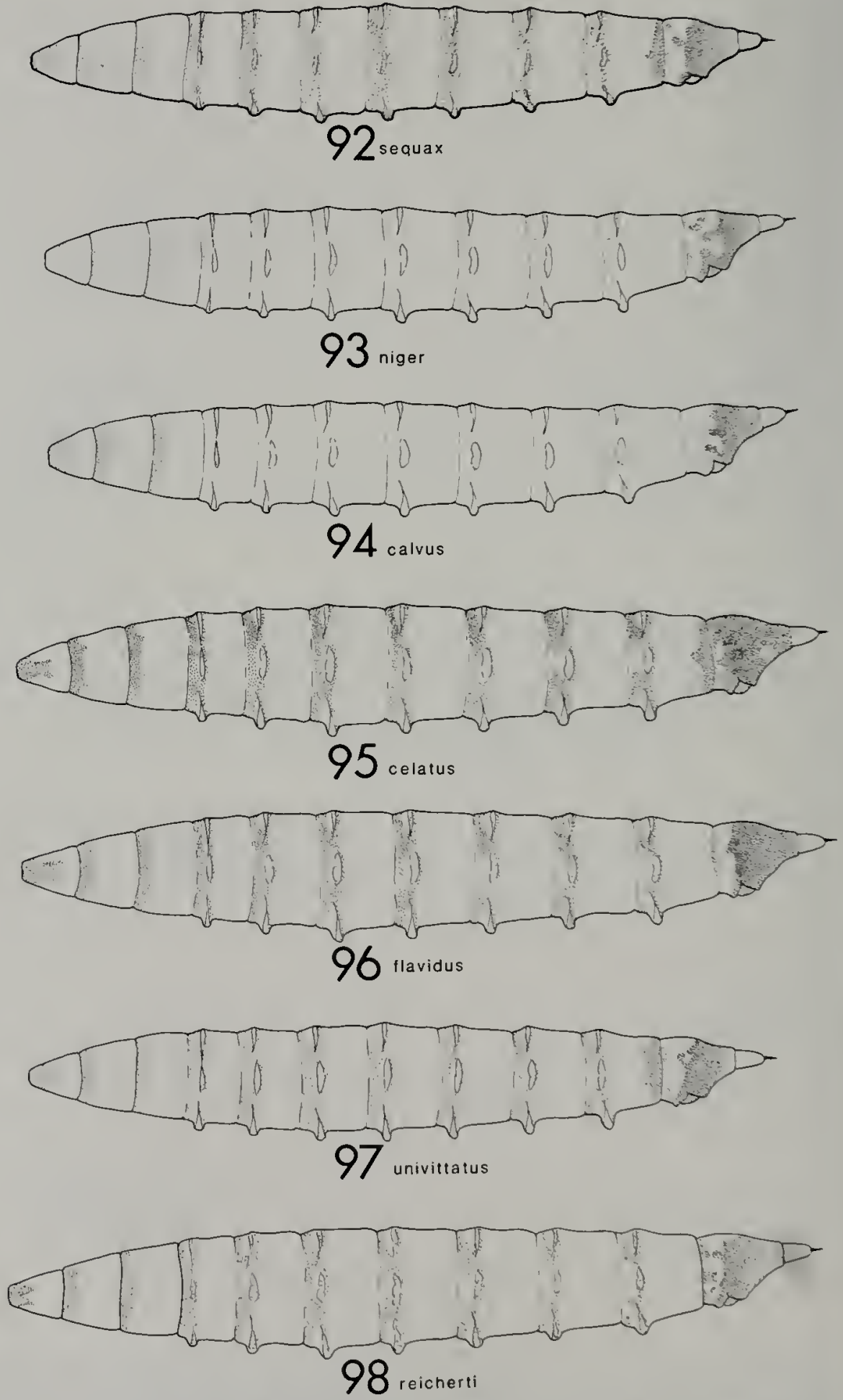

Fig 92-98.-Larvae. 92. Chrysops sequax. 93. C. niger. 94. C. calvus. 95. C. celatus 96. C. flavidus. 97. C. univittatus. 98 . C. reichertI. 

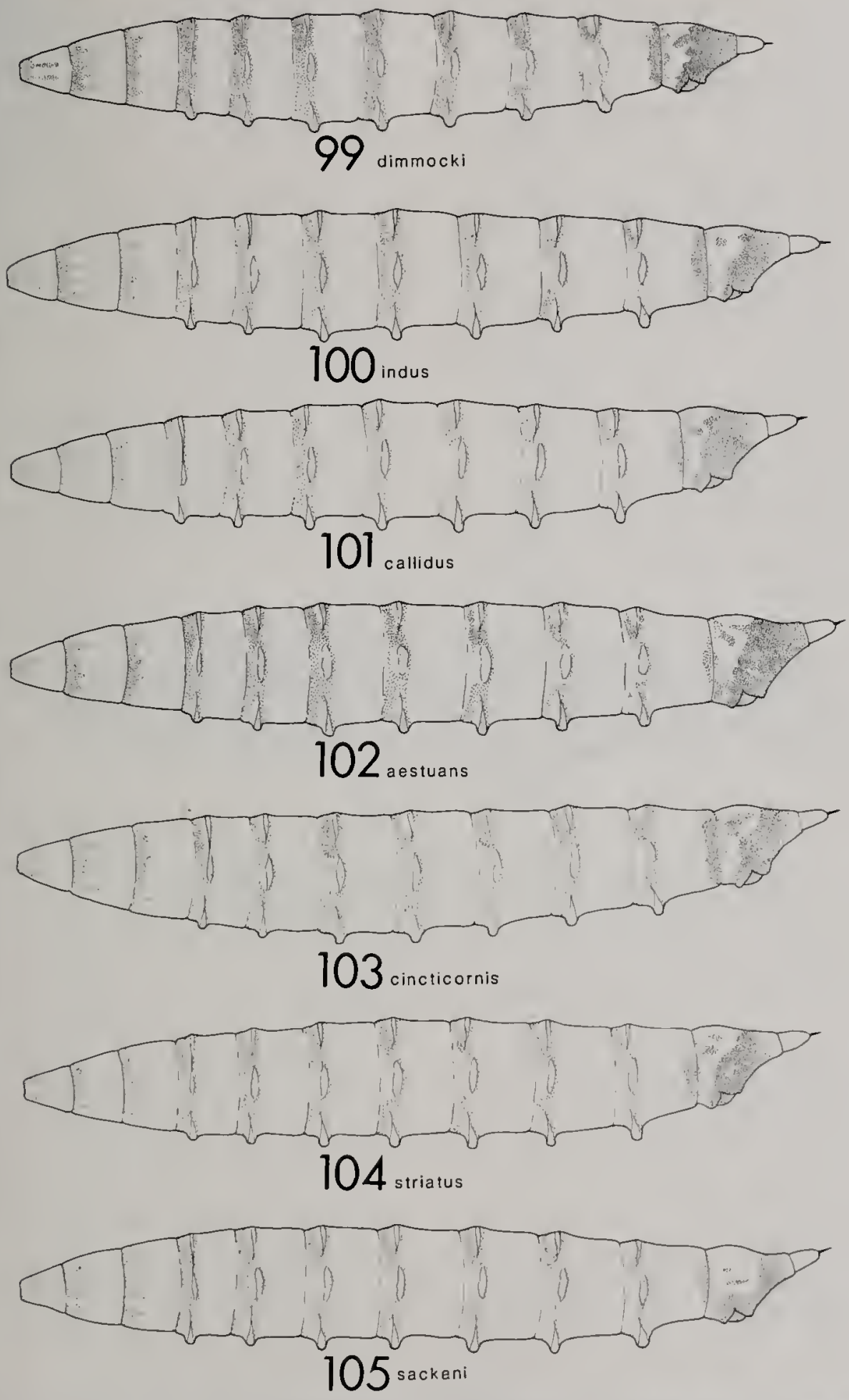

Fig. 99-105.-Larvae. 99. Chrysops dimmockl. 100. C. Indus. 101. C. cailidus. 102. C. aestuans. 103. C. cincticornis. 104. C. striatus. 105. C. sackeni. 

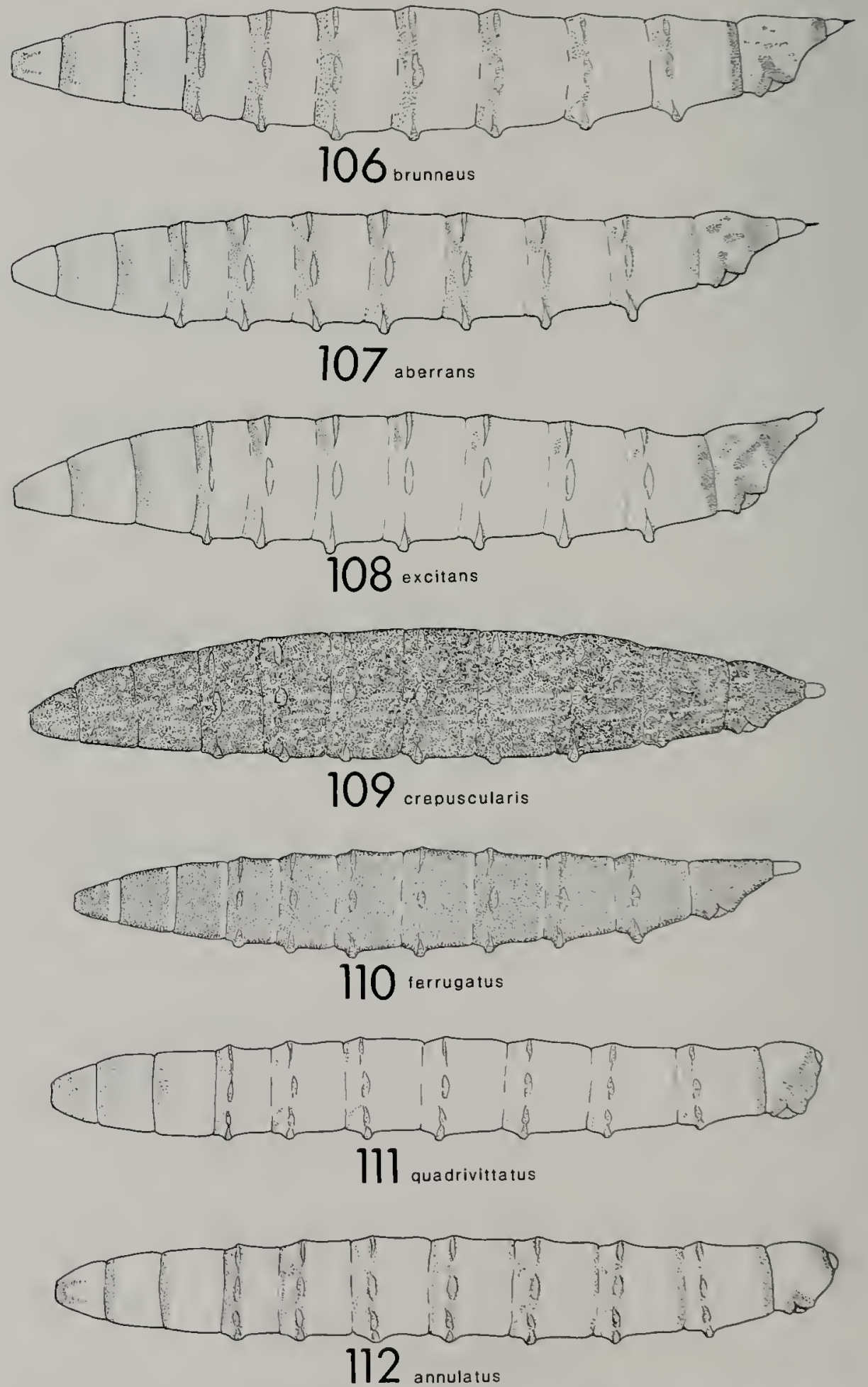

Fig. 106-112.-Larvae. 106. Chrysops brunneus. 107. C. aberrans. 108. C. excltans. 109. Chlorotabanus crepuscularls. 110 . Diachlorus ferrugatus. 111. Silvius quadrivittatus. 112. Leucotabanus annulatus. 
14. Prothoracic annulus with single broad posterior pubescent projection on each side, as if area between usual paired projections were filled with pubescence (Fig. 95, 97) ...................... I5

Prothoracic annulus with paired pubescent projections on each side ................. 17

15. Posterior pubescence on anal segment extends forward dorsally at least three-quarters length of segment (Fig. 95, 96)

Posterior pubescence on anal segment extends forward dorsally little more than half length of segment (Fig. 97) univittatus, upsilon

16. Pubescence covers about nine-tenths of anal segment; only narrow encircling band on its anterior margin clear. Posterior pubescent annulus of preanal segment with distinct anterior projections laterally (Fig. 95) .....................celatus

Pubescence on anal segment less extensive, covering approximately threequarters of segment. Posterior pubescence on preanal segment restricted to lateral surfaces, without anterior projections (Fig. 96) ....................flavidus

17. Lateral pubescent projections from prothoracic annulus either expanded apically (Fig. 99, 100) or basally broad where leaving annulus (Fig. 98) ..........18

Lateral pubescent projections from prothoracic annulus slender, tapered (Fig. 103, 108)

18. Pubescence absent from posterior margin of abdominal segment 7 (Fig. 98) reicherti

Pubescence encircles posterior margin of abdominal segment 7 ....................... 19

19. Patch of pubescence dorsolaterally on anal segment closely proximal to, or continuons with, pubescence on anterior border of same segment (Fig. 100). indus

Patch of pubescence dorsolaterally on anal segment forming tonguelike anterior projection of posterior annulus (Fig. 99) dimmocki

20. Anterior pubescence encircles only first abdominal segment (Fig. 103, 108).....2।

Anterior pubescence encircles first 3-5 abdominal segments (Fig. 101, 102, 104-107)

21. Proleg pubescence on segments 5 to 10 greatly reduced, as evidenced by its not traversing spaces between protegs. Posterior pubescent annulus on anal segment not united to pubescence on anal ridges (Fig. 108). excitans

Proleg pubescence encircles segments 5 to 10. Posterior pubescent annulus on anal segment united to pubescence on anal ridges at least ventrally (Fig. 103, 104).

22. Posterior pubescence on preanal segment with single short anterior pro- jection midlaterally (Fig. 104) ......striatus

Posterior pubescence on preanal segnent with four short anterior projections midlaterally (Fig. 103)

\section{mitis, cincticornis}

23. Posterior pubescent annulus on anal segment extends forward dorsally over at least half length of seginent, usually broadly connected to pubescence on anal ridges (Fig. 101, 102).....24

Posterior pubescent annulus on anal segment extends forward dorsally less than half length of segment, its connection to anal ridge pubescence, if present, usually only on ventral sur. face (Fig. 104-107).

24. Posterior pubescent annulus on anal segment extends forward dorsally only half length of segment, usually enclosing clear nompubescent areas ventrolaterally behind anns (Fig. 102) aestuans

Posterior pubescent annulus on anal segment usually extends forward dorsally more than half length of segment, only occasionally enclosing clear areas ventrolaterally (Fig. 101) ..callidus

25. Posterior pubescent annulus on anal segment lacks any direct ventral connection with pubescence on anal ridges, although narrow connection may exist through lateral club-shaped projections from posterior annulus. Anterior pubescence encircles first 4 or 5 abdominal segments (Fig. 106 , 107)....

Posterior pubescent annulus on anal segment connected ventrally to pubescence on anal ridges or shows vestiges of ventrolateral connections. Anterior pubescence encircles first 2 or 3 abdominal segments (Fig. 105) sacken i

26. Anal segment with lateral club-shaped pubescent projection from posterior annulus and paired oval dorsolateral paiches of pubescence, lower one being larger (Fig. 107) ................aberrans

Anal segment with midlateral pubescent har not connected to posterior annulus, several small pubescent spots dorsolaterally (Fig. 106) ............brunneus

\section{Chrysops aberrans Philip}

Chrysops aberrans Philip (1941:122). Typelocality: Minnesota, Ramsay County. Moderate size $(8 \mathrm{~mm})$; yellow and black; frontoclypeus shining yellow; frontal callus usually yellow, sometimes brown or black; thorax greenish in ground color; scutellum dark; black stripes on abdomen, median pair rarely joining on second tergite; apical 
spot broad (Fig. 38), usually nearly filling second submarginal cell; hyaline triangle does not reach second longitudinal vein; crossband broad, covering discal cell, reaching hind margin of wing; first basal cell infuscate; second basal cell hyaline; fifth posterior cell mostly hyaline. Male with yellow areas reduced; second basal cell largely infuscated.

C. aberrans is often confused with $C$. striatus. The two species are much alike and often fly together but can be distinguished by the characters given in the key. Although the frontal callus is typically yellow, some populations run rather heavily to individuals with the callus brown or black.

The larvae (Fig. 107) are most commonly collected from mud or sand at the edges of ponds and lakes but have also been taken from a variety of other semiaquatic habitats (Pechuman I972; Teskey 1969).

This species is most commonly collected in and near cattail swamps. In Illinois adults appear in late June and have been collected until late August.

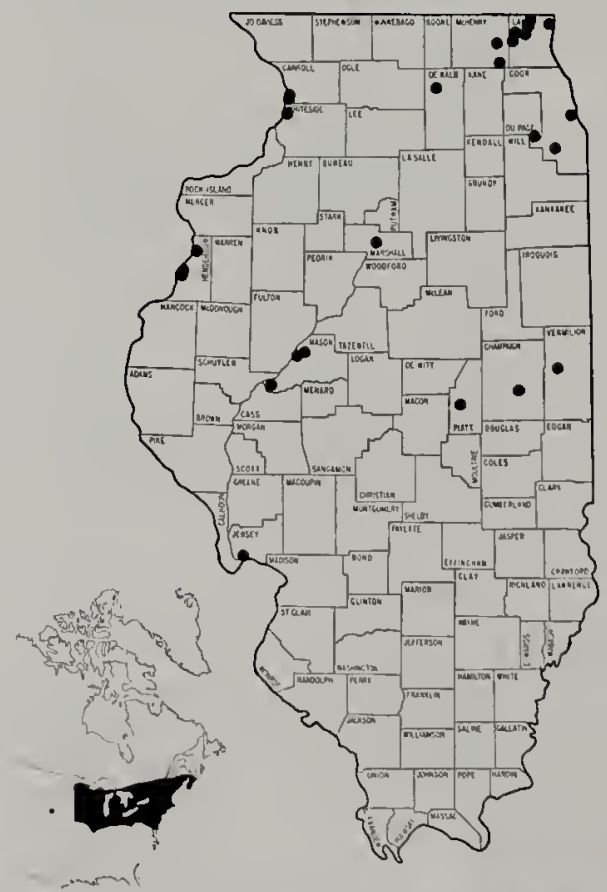

Fig. 113.-Distribution of Chrysops aberrans in Illinois and North America.
Its peak abundance is from mid-July to mid-August.

C. aberrans is an east-central species, extending from New Jersey to Nova Scotia and west to Minnesota and Iowa, with a possible disjunct population in Nebraska (Fig. 113). In Illinois this species is found in the northern twothirds of the state (Fig. I13).

\section{Chrysops aestuans Wulp}

Chrysops aestuans Wulp ( I867:135). Typelocality: Wisconsin.

Chrysops moerens Walker (1848:201). Type-locality: Nova Scotia.

Moderate size $(8.5 \mathrm{~mm})$; black; frontoclypeus shining yellow; frontal callus black; abdomen with gray or yellowish gray markings not in form of stripes, black triangles on second abdominal segment. one on each side of median dark marking, triangles may or may not be connected with latter by dark band along posterior margin of segment; apical spot narrow, reaching extreme apex of second submarginal cell; hyaline spot (Fig. 39) broad. extending apically toward costal margin beyond second longitudinal vein: crossband saturate, covering discal cell. usually not reaching hind margin of wing; both basal cells hyaline, fifth posterior cell infuscate basally: Male generally darker; both basal cells partly infuscated.

C. aestuans belongs in a difficult taxononic group, which includes $C$. callidus, C. dimmocki, C. pudicus, C. sackeni, and some rarer forms. However, most specimens can be separated by the characters given in the key.

The larvae (Fig. 102) have been found in marshes bordering large bodies of water. The eggs are laid on emergent vegetation, often over rather deep water (Pechuman 1972: Teskey 1969). This species is normally collected near large bodies of water. In Illinois adults appear in early June and have been collected through mid-Àugust.

C. aestuans is widespread across the central United States and Canada. extending from Nova Scotia to British 


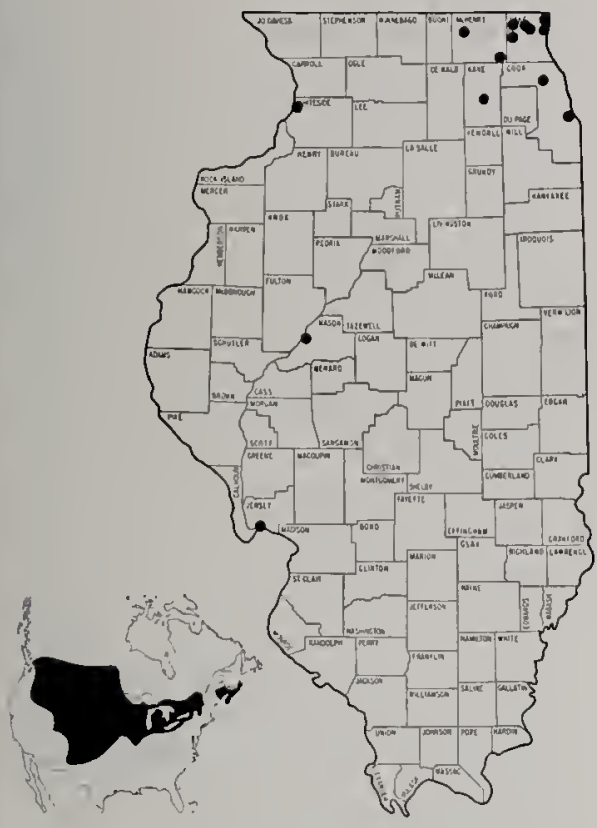

Fig. 114.-Distribution of Chrysops aestuans in Illinois and North America.

Columbia and Oregon (Fig. 114). In Illinois this species is found in various parts of the northern two-thirds of the state, particularly in Lake County (Fig. 114).

\section{Chrysops ater Macquart}

Chrysops ater Macquart (1850:344). Typelocality: Newfoundland.

Chrysops carbonarius nubiapex Philip (1955:92). Type-locality: New York, Little Valley.

Chrysops fugax Osten Sacken (1875: 375). Type-locality: Maine, Norway (lectotype).

Moderate size ( $8 \mathrm{~mm}$ ); black; abdomen entirely black; no apical spot but occasionally a trace of infuscation in apical area; hyaline spot covers apical third of wing (Fig. 40); crossband covers discal cell, often not reaching hind margin of wing, outer margin usually irregular; both basal cells more than half infuscated; fifth posterior cell with distinct to vague hyaline area at base. Male with both basal cells at least threefourths infuscated; frequently with apical infuscation but not a distinct apical spot.
Previously, this species had been synonymized with $C$. carbonarius. The less intensely infuscated and less extensive crossband with an irregular outer margin and the less clear-cut hyaline area at the base of the fifth posterior cell separate most specimens of $C$. ater from $C$. carbonarius.

The triple-tiered egg mass is deposited on tree leaves or other vegetation overhanging ponds or portions of streams where the water is barely in motion. The larvae (Fig. 88) are found in mud and organic matter along streams (Pechuman 1972; Teskey 1969).

In Illinois adults appear in early June and have been collected until early July.

C. ater is a widespread species, extending from Virginia to Newfoundland and west to Alberta and Utah, with a disjunct population in Alaska (Fig. 115). It is conceivable that this species extends from Alberta to Alaska. In Illinois this species is known only from three northern records.

Illinois Records.-Ogle County, I mile N Polo; Stephenson County, 2 miles S Orangeville; Winnebago County, 4 miles NW Durand.

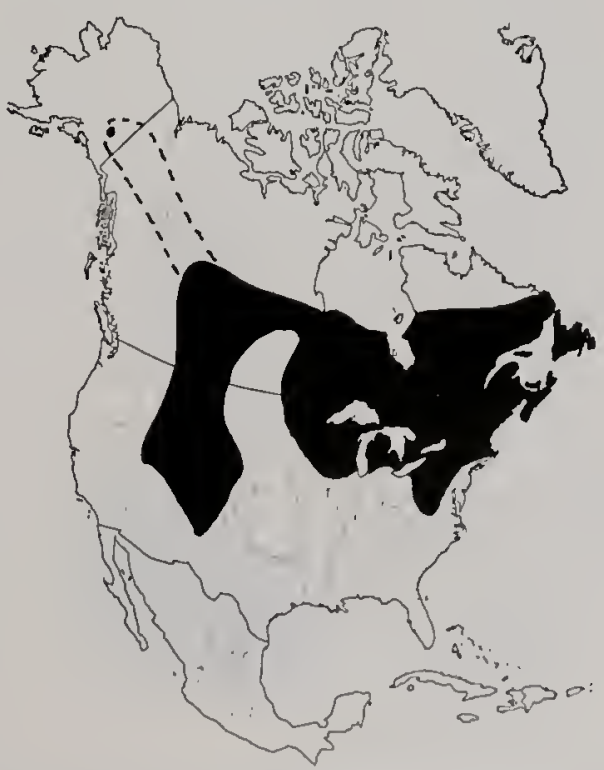

Fig. 115.-Distribution of Chrysops ater in North America. 


\section{Chrysops beameri Brennan}

Chrysops beameri Brennan (1935:265). Type-locality: Kansas, Comanche County.

Moderate size $(8 \mathrm{~mm})$; yellow and black; frontoclypeus shining yellow; frontal callus yellow; thorax yellow to greenish yellow in ground color; abdomen with black stripes, 4 stripes of about equal intensity or central stripes only slightly accentuated; apical spot broad but usually only barely reaching first posterior cell (Fig. 41); hyaline triangle reaches second longitudinal vein, apex pointed; crossband covers discal cell, narrowed posteriorly but reaches hind margin of wing; first basal cell infuscated; second basal cell hyaline; fifth posterior cell hyaline. Male similar to female, including wing characters; first basal cell completely infuscated; second basal cell completely hyaline.

This species is in a taxonomic group with $C$. hinei and can be confused with paler specimens of $C$. hinei. The characters in the key are generally sufficient to separate these two species.

The larvae of $C$. beameri are unknown.

This species is widespread in the eastern and southern United States, extending from northern Florida to New Jersey and west to Kansas and eastern Texas (Fig. 116). As yet this species has not been collected in 1llinois although specimens have been examined from western Indiana and eastern Missouri. This species is a late season flyer and is not often collected.

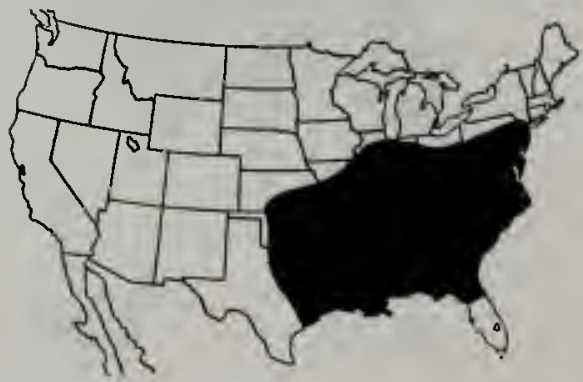

Fig. 116.-Distribution of Chrysops beamerl in North America.

\section{Chrysops brunneus Hine}

Chrysops brunneus Hine (1903:34). Typelocality: Ohio, Sandusky.

Rather large $(9 \mathrm{~mm})$; brown; frontoclypeus shining yellow; first antennal segment swollen; abdominal pattern obsolete, sometimes with dark shadows and faint pale median triangles; apical spot broad (Fig. 42), continues around wing, joining crossband by lightly infuscated area along hind margin; hyaline triangle isolated, not reaching second longitudinal vein; crossband broad, covering discal cell, reaching posterior margin of wing, and joining with extended apical spot; both basal cells partly infuscated; fifth posterior cell diffusely infuscated. Male differs from female only in sex characters.

$C$. brunneus is a rather distinctive species, and the characters in the key readily separate it from other species.

Like the larvae of some other species of Chrysops, brumeus larvae apparently may live in either fresh or brackish water habitats. The single known larva was taken between the

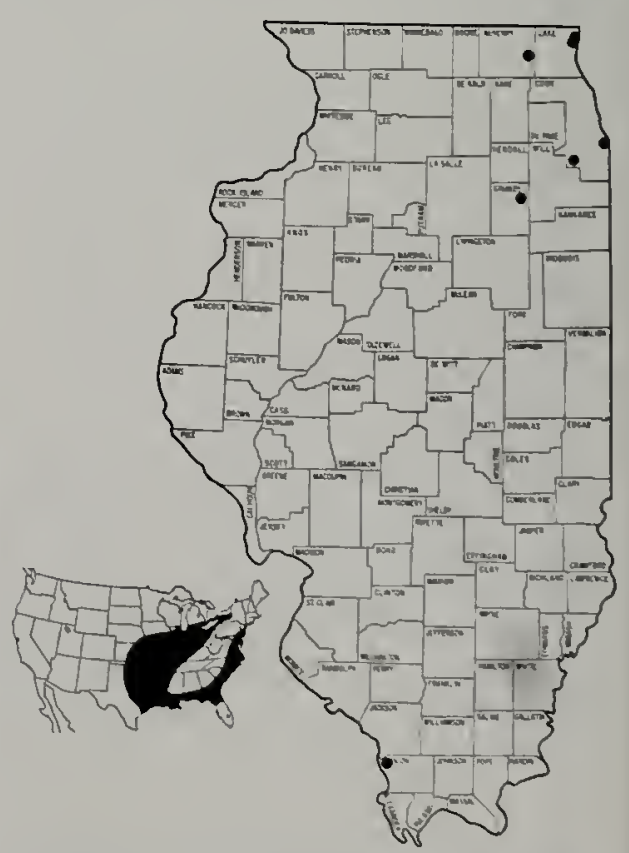

Fig. 117.-Distribution of Chrysops brunneus in Illinois and North America. 
basal portion of the leaves of Spartina in a salt marsh (Goodwin 1976a).

In Illinois adults of this species appear in mid-June and have been collected until late August.

C. brunneus is a central and eastern species, extending along the Atlantic coast states from Florida to New York, west to Texas, then north through the central states, and northeast into southern Ontario and into upstate New York along Lake Ontario (Fig. 117). In 1llinois this species has most often been collected in the northeast, with a single record from Union County in southern Illinois (Fig. 117).

\section{Chrysops callidus Osten Sacken}

Chrysops callidus Osten Sacken (1875:

379). Type-locality: lllinois (lectotype).

Moderate size $(8 \mathrm{~mm})$; black and yellow; frontoclypeus shining yellow; front somewhat convergent at vertex; pale markings of abdomen yellow (sometimes quite bright), markings not in form of stripe, dark median markings of second abdominal segment may have projections along posterior margin of segment but these projections do not form lateral triangles; apical spot narrow (Fig. 43), varies from onehalf width to full width of marginal cell; hyaline triangle broad, rounded apically, just reaching or barely crossing second longitudinal vein; crossband covers discal cell, narrowed posteriorly but reaches hind margin of wing; both basal cells hyaline; fifth posterior cell infuscated basally. Male with pale markings less extensive; both basal cells partly infuscated.

C. callidus belongs in a difficult taxonomic group, which includes $C$. aestuans, C. dimmocki, C. pudicus, C. sackeni, and some rarer forms. However, most specimens can be separated by the characters given in the key.

The larvae (Fig. 101) are found in a variety of situations, including mud on the shores of ponds and slow-moving streams, wet organic material, and around the roots of plants growing at the water's edge. Larvae have also been collected under as much as $1 \mathrm{~m}$ of water as far as $10 \mathrm{~m}$ from the shoreline. The flat, one-layered egg masses are found only over water. These masses, which shortly after oviposition become dark and shining, are laid along the edges of creeks and ponds on emergent vegetation, but none are found on similar adjacent growth over mud. Since these egg masses are often quite abundant and noticeable, this selectivity is striking (Jones \& Bradley 1923; Pechuman 1972; Teskey 1969; Tidwell 1973).

In Illinois adults of this species appear in early April and have been collected until late August. Its peak abundance is from mid-June until late July.

C. callidus is an eastern and central species, extending from Florida to Maine and west to South Dakota and Texas (Fig. 118). This species is widespread throughout Illinois (Fig. 118). It is active and aggressive and causes considerable annoyance to man and livestock.

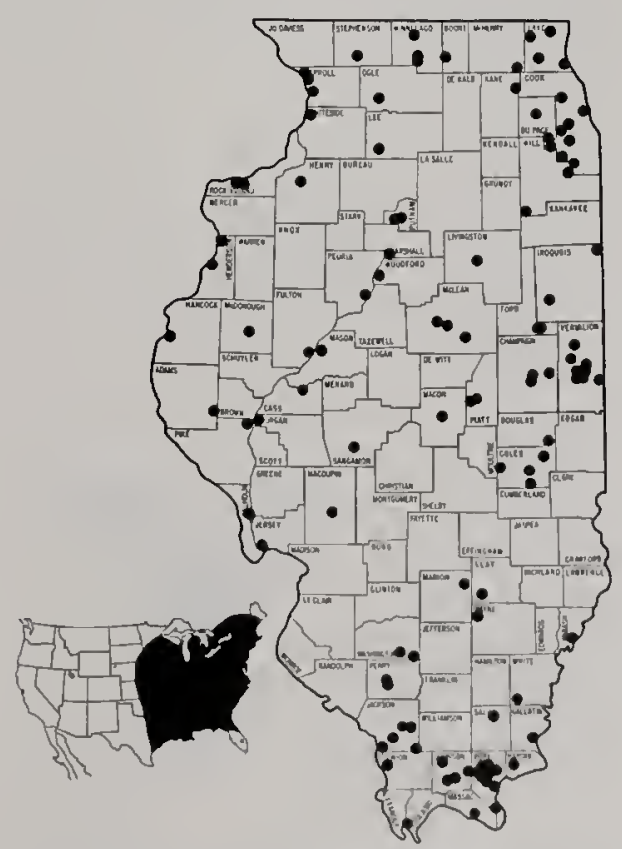

Fig. 118.-Distribution of Chrysops callidus in Illinois and North America. 
Chrysops calvus Pechuman \& Teskey

Chrysops calous Pechuman \& Teskey (1967:645). Type-locality: New York, Allegany State Park.

Moderate size $(8.5 \mathrm{~mm})$; blackish; frontoclypeus without median pollinose stripe; central area of vertex bare, uninterrupted by pollinose band; sublateral thoracic stripes bright, distinct; no apical spot except in some specimens as narrow line along costal border (Fig. 44); no hyaline triangle; crossband saturate, black, covers discal cell, reaching hind margin of wing; first basal cell infuscated; second basal cell hyaline; fifth posterior cell hyaline. Male wing with both basal cells largely infuscated. Face with considerable yellow in both sexes.

This species until recently (Pechuman \& Teskey 1967) was included with $C$. niger but may be separated by the characters given in the key. Teskey (1969) has shown the larva of $C$. calvius to be separable from that of $C$. niger.

Larvae (Fig. 94) were taken from saturated clay soil on the banks of a pool in a flood channel of a brook (Teskey 1969).

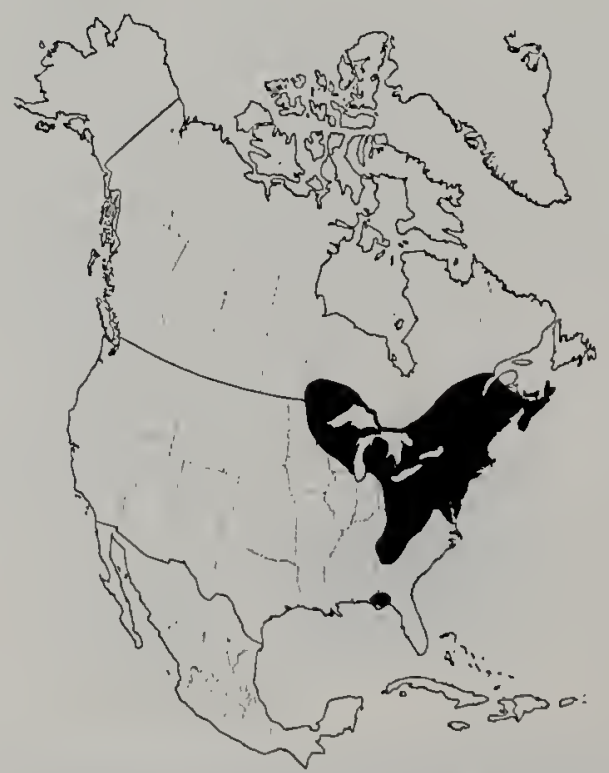

Fig. 119.-Distribution of Chrysops calvus in North America.
C. calous is an eastern and northcentral species, extending from Georgia to Nova Scotia and west to Minnesota and northern Ontario. A disjunct population is present in the panhandle of Florida (Fig. 119). As yet this species has not been collected in 1llinois although specimens have been examined from southeastern Wisconsin.

\section{Chrysops carbonarius Walker}

Chrysops carbonarius Walker (1848:203).

Type-locality: Nova Scotia.

Moderate size $(8.5 \mathrm{~mm})$; black; frontoclypeus with median pollinose stripe; abdomen entirely dark; no apical spot or hyaline triangle (Fig. 45); crossband broad, covers discal cell, not tapered posteriorly, reaches hind margin of wing, outer margin straight or slightly bowed; both basal cells more than half infuscated; fifth posterior cell with clear-cut hyaline area at base. Male with both basal cells at least threefourths infuscated; hyaline area at base of fifth posterior cell clear-cut, as in female.

This species is very similar to $C$. ater although specimens can be readily separated by the characters given in the key.

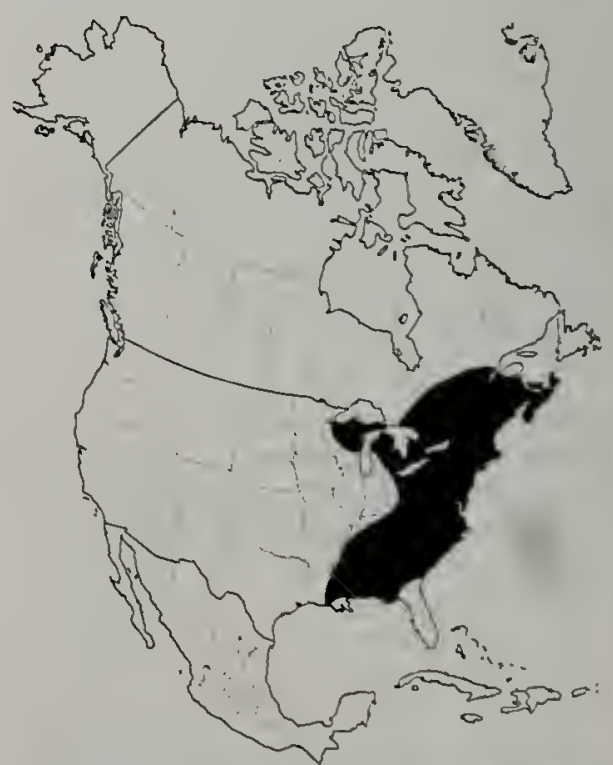

Fig. 120.-Distribution of Chrysops carbonarius in North America. 
The larvae (Fig. 87) have been found in saturated mud on the banks of streams and ponds (Pechuman 1972; Teskey 1969).

C. carbonarius is primarily an eastern species, extending from northern Florida to Nova Scotia and west to Wisconsin and Louisiana (Fig. 120). As yet this species has not been collected in lllinois although specimens have been examined from central Wisconsin.

\section{Chrysops celatus Pechuman}

Chrysops celatus Pechuman (1949:82).

Type-locality: New Jersey, Medford Lakes.

Moderate size (8.5 $\mathrm{mm})$; yellowish brown; frontoclypeus shining yellow; frontal callus yellow; thorax greenish gray with fuscous stripes: abdomen with dark brown or blackish markings not in form of stripes, median marking of second abdominal segment rarely attains anterior margin; apical spot broad (Fig. 46), covering more than half of second submarginal cell; hyaline triangle does not reach second longitudinal vein; crossband broad, covering discal cell, reaching hind margin of wing, outer margin usually sinuate; basal half of first basal cell infuscate; second basal cell hyaline; basal half of fifth posterior cell infuscate; hind femora yellow. Male easily associated with female.

This species was treated as a subspecies of C. flavidus (Pechuman 1957), but its separation at the specific level is justified by the lack of intergrades with flavidus. This fact is further con-

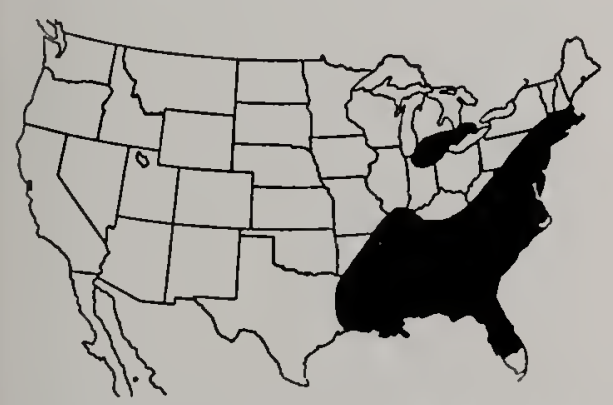

Fig. 121.-Distribution of Chrysops celatus in North America.
Firmed by Teskey (1969), who found the larvae of the two forms to be distinct.

The larvae (Fig. 95) have been found in sand and mud at the edges of ponds and lakes and in highly organic boglike situations (Pechuman 1972; Teskey 1969; Tidwell 1973).

This species has been collected only once in Illinois in late July.

C. celatus is a southeastern species, extending from Florida to Massachusetts and west to eastern Texas (Fig. 121). A disjunct population occurs in northern Indiana, Ohio, and southern Michigan and Ontario.

Illinois Records.-Johnson County, Little Black Slough Nature Preserve, 4 miles SW Vienna).

\section{Chrysops cincticornis Walker}

Chrysops cincticornis Walker (1848:201).

Type-locality: unknown.

Chrysops celer Osten Sacken (1875:376).

Type-locality: Massachusetts (lectotype).

Rather large $(9 \mathrm{~mm})$; black; frontoclypeus with median pollinose stripe; pleura with yellow to orange-red pile; abdomen entirely dark; no apical spot or hyaline triangle (Fig. 47); crossband broad, covering discal cell, broadly reaching hind margin of wing; both basal cells with basal half infuscate; fifth posterior cell infuscate at base. Male lacks orange pleural pile of female; anal area of wing dilutely infuscate.

Earlier workers discussed this species as $C$. celer, subsequently synonymized under cincticornis. The females are distinctive from other lllinois species of Chrysops because of the orangered pile on the thoracic pleura.

The larvae (Fig. 103) are found in the muddy edges of ponds and streams. The egg mass is brown and in several layers, much like a Tabanus egg mass (Pechuman 1972; Teskey 1969; Tidwell 1973).

In Illinois adults of this species appear in mid-May and can be collected until late July. Most specimens have 


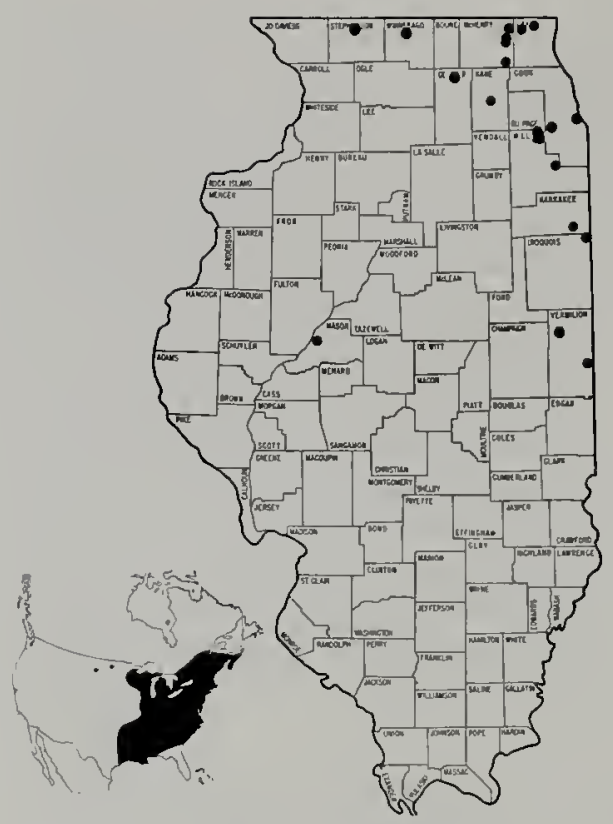

Fig. 122.-Distribution of Chrysops cincticornis in Illinois and North America.

been collected around the margins of lakes and bogs in Lake and McHenry counties.

C. cincticornis is a central and eastern species, extending from Georgia to Nova Scotia and west to Minnesota and eastern Texas (Fig. 122). Two disjunct records are known from North Dakota. In Illinois (Fig. 122) this species has been collected only in the northern half of the state.

\section{Chrysops cuclux Whitney}

Chrysops cuclux Whitney (1879:35). Typelocality: New Hampshire, Milford.

Moderate size ( $8 \mathrm{~mm})$; black; frontoclypeus with median pollinose stripe; pleura with gray pile; abdomen with pale grayish yellow area laterally near base, no median abdominal triangles; no apical spot or hyaline triangle (Fig. 48): crossband broad, pale, covering discal cell, generally reaching hind margin of wing although very pale in this area; basal half of both basal cells infuscate, pale. In male, pale area of abdomen smaller than in female.

This species is similar to C. excitans although the wing picture is distinctly paler and abdomen has no middorsal pale markings.

The larvae (Fig. 86) are known from wet mud along streams and occasionally from pond margins (Pechuman 1972; Teskey 1969).

C. cuclux is a northeastern species, extending from Georgia to Nora Scotia and west to Wisconsin (Fig. 123). A disjunct population has been examined from northwestern Ontario. As yet this species has not been collected in Illinois although specimens have been examined from southeastern Wisconsin and northwestern Indiana.

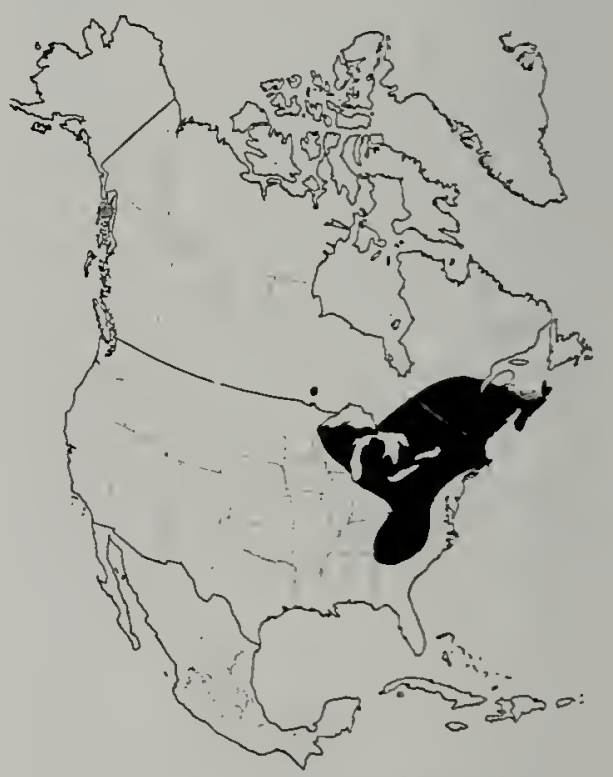

Fig. 123.-Distribution of Chrysops cuclux in North America.

\section{Chrysops dacne Philip}

Chrysops dacne Philip (1955:99). Typelocality: Georgia, Clarke County.

Moderate size $(7.5 \mathrm{~mm})$; dark brown: frontoclypeus shining yellow; no pale stripe above wing base: abdomen often with narrow pale median line, rarely with obsolete sublateral lines; apical spot very broad (Fig. 49), covering all of second submarginal cell; hyaline triangle narrow, not clearly reaching second longitudinal vein; crossband broad, covering discal cell, broadly reaching hind margin of wing; first 
basal cell completely infuscated; second basal cell hyaline; fifth posterior cell hyaline; hind legs predominately yellow or brown. Male with hyaline areas of wing somewhat tinted.

For many years this species was called C. lugens, but the name lugens should be used for another form. This species resembles $C$. parvulus although the yellowish hind legs and the extension of the apical spot into the first posterior cell readily separate $C$. dacne from parvulus.

Immature stages are unknown.

$C$. dacne is a southern and eastern species, extending from northern Florida to Massachusetts and west to eastern Texas (Fig. 124). This species is reported in the literature from the southwesternmost county of Michigan although this specimen has not been examined. As yet this species has not been collected in Illinois.

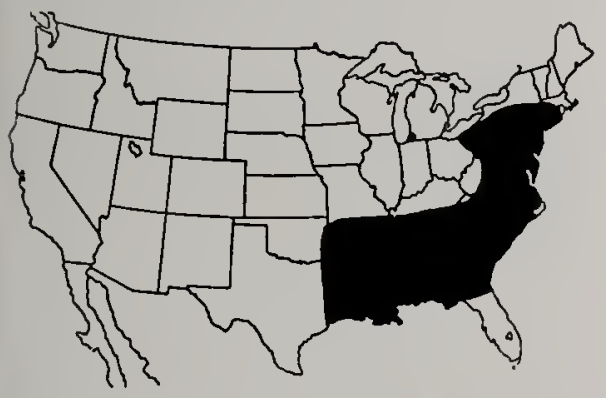

Fig. 124.-Distribution of Chrysops dacne in North America.

\section{Chrysops dimmocki Hine}

Chrysops dimmocki Hine (1905:393). Typelocality: Massachusetts, Longmeadow. Moderate size $(8 \mathrm{~mm})$; black and yellow; frontoclypeus shining yellow; frontal callus normally black but sometimes yellow; abdominal markings not in form of stripes, median marking of second abdominal segment usually reaches anterior margin; apical spot broad (Fig. 50), covering apical half of second submarginal cell; hyaline triangle broad, not reaching second longitudinal vein; crossband broad, covering discal cell, narrowing posteriorly but generally reaching hind margin of

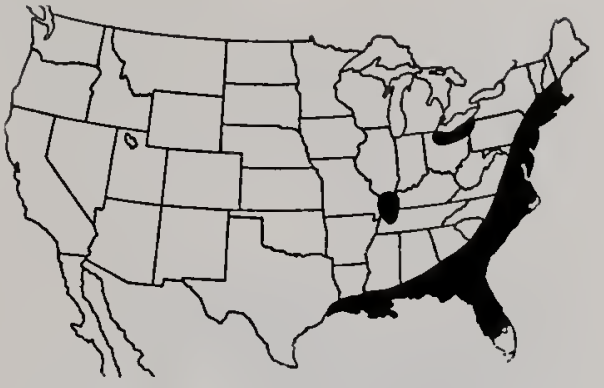

Fig. 125.-Distribution of Chrysops dimmocki in North America.

wing; both basal cells hyaline; fifth posterior cell with basal margin infuscate; at least basal portion of hind femora black. Male with both basal cells partly infuscated.

This species resembles both $C$. celatus and $C$. flaridus, but the characters in the key suffice to separate $C$. dimmocki from both of these species.

The larvae (Fig. 99) have been collected in organic substrates in swamps as well as in mud and sand at the edges of ponds (Pechuman 1972; Teskey 1969; Tidwell 1973).

Adults of this species have been collected only twice in Illinois in midMay and late June.

C. dimmocki is a southeastern species, extending from southern Florida to New Hampshire and west to eastern Texas (Fig. 125). Two disjunct populations are present in the central states, one in southern Illinois and western Tennessee, the other in Ohio and northwestern Pennsylvania.

Illinois Records.-Massac County; Unionville; Union County, Pine Hills Recreational Area.

\section{Chrysops excitans Walker}

Chrysops excitans Walker (1850:72). Typelocality: Nova Scotia, Cape Breton Island.

Chrysops lubalis Harris (1925:68). Nomen nudum.

Large species (10 mum); black; frontoclypeus with median pollinose stripe; pleurae with dense yellowish pile; abdomen with yellow area laterally near base, usually with median triangles on 
second, third, and sometimes fourth tergites; no apical spot or hyaline triangle (Fig. 51); crossband broad, covering discal cell, not reaching hind margin of wing; both basal cells with basal half infuscate; fifth posterior cell with basal half infuscate. Male much darker than female, with pale abdominal markings reduced or obsolete.

This species resembles $C$. cuclux, but the much darker wing picture and the presence of yellowish pile on the thoracic pleurae and pale middorsal abdominal markings readily identify this species.

The larvae (Fig. 108) are found in mud and organic habitats along the edges of pools, ponds, and lakes (Pechuman 1972; Teskey 1969).

C. excitans is a northern species, extending from Virginia to Labrador and west to California and Alaska (Fig. 126). In lllinois this species has been collected once in late June 1892.

Illinois Records.-Lake County, Grass Lake.

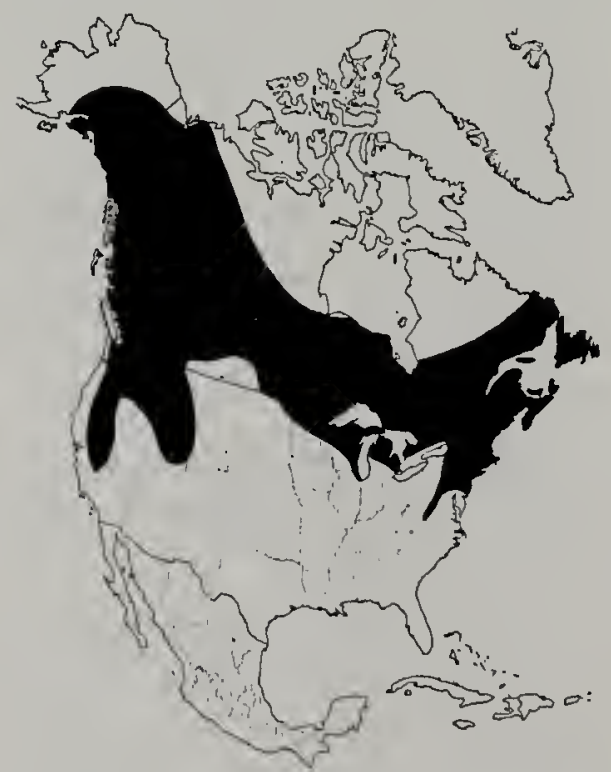

Fig. 126.-Distribution of Chrysops excitans in North America.

\section{Chrysops flavidus Wiedemann}

Chrysops flavidus Wiedemann (1821:55).

Type-locality: Georgia, Savanmah.
Chrysops canifrons Walker (1848:197). Type-locality: Florida.

Chrysops pallidus Bellardi (1859:73).

Type-locality: Mexico.

Moderate size $(8.5 \mathrm{~mm})$; yellow and brown; frontoclypeus shining yellow; frontal callus yellow; thorax yellow with brown stripes; abdomen with brown markings not in form of stripes; apical spot broad (Fig. 52), covering apical half of second submarginal cell; hyaline triangle broad, not reaching second longitudinal vein; crossband broad, covering discal cell, narrowed posteriorly, reaching hind margin of wing; both basal cells somewhat infuscate at base; fifth posterior cell with basal half infuscate; hind femora yellow; sometimes brownish at base. Male differs from female only in sex characters.

This species resembles $C$. celatus, and was previously considered a subspecies of flavidus. The characters designated in the key will separate these two species.

The larvae (Fig. 96) have been taken from ponds, streams, and marshes (Jones \& Bradley 1923; Pechuman 1972; Teskey 1969; Tidwell 1973).

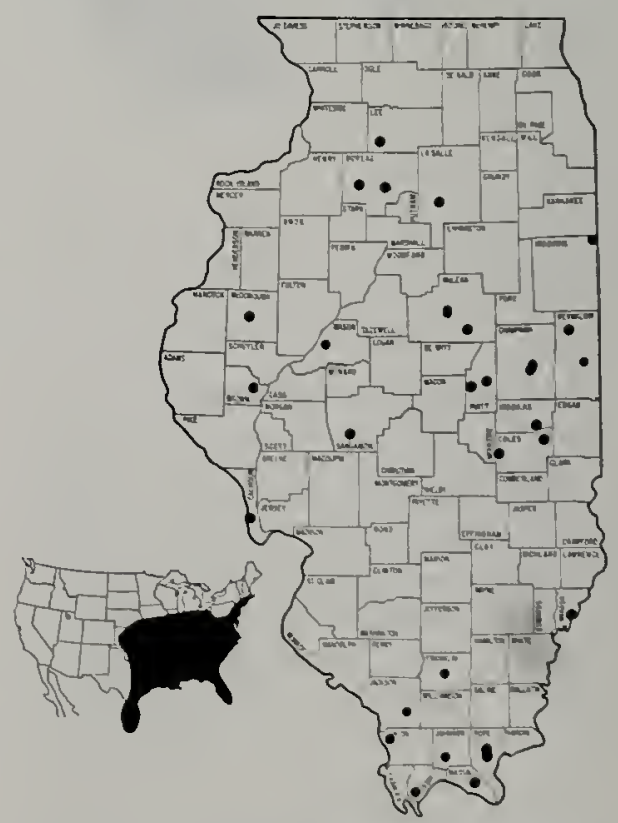

Fig. 127.-Distribution of Chrysops flavidus in Illinois and North America. 
In Illinois adults appear in late May and have been collected until early September.

C. flavidus is a widely distributed species, extending from the southern tip of Florida to Massachusetts, west to Missouri and northeastern Mexico, and to Cuba and the Bahamas (Fig. 127). In Illinois this species has been collected in the southern two-thirds of the state (Fig. 127).

\section{Chrysops frigidus Osten Sacken}

Chrysops frigidus Osten Sacken (1875: 384). Type-locality: New York, Sharon Springs (lectotype).

Chrysops canadensis Kröber (1926:277).

Type-locality: Ontario, Ottawa.

Moderate size $(7.5 \mathrm{~mm})$; black and orange; frontoclypeus black with median pollinose stripe; thorax and pleurae with yellow pile; color pattern of abdomen variable, sometimes almost completely black or almost completely orange yellow, but pattern never in form of longitudinal stripes; apical spot broad (Fig. 53), broadly united with crossband, covers entire upper branch of third longitudinal vein; hyaline triangle does not extend beyond third longitudinal vein; crossband broad, covering discal cell, not reaching hind margin of wing; both basal cells partly infuscated; fifth posterior cell with basal half infuscate; legs often with considerable yellow, hind tibiae never completely black. Male with infuscation in both basal cells greater than that in female.

This species is rather distinct from other species of Chrysops, having a yellow pile on the thorax and pleurae. The characters in the key readily separate this species.

The larvae (Fig. 90) are usually found in mossy substrates in bogs and swanps and along streams and ponds (Pechuman 1972; Teskey 1969).

In Illinois adults appear in early June and can be collected until late July.

C. frigidus is a northern species, extending from New York to Labrador and west to British Columbia (Fig. 128).

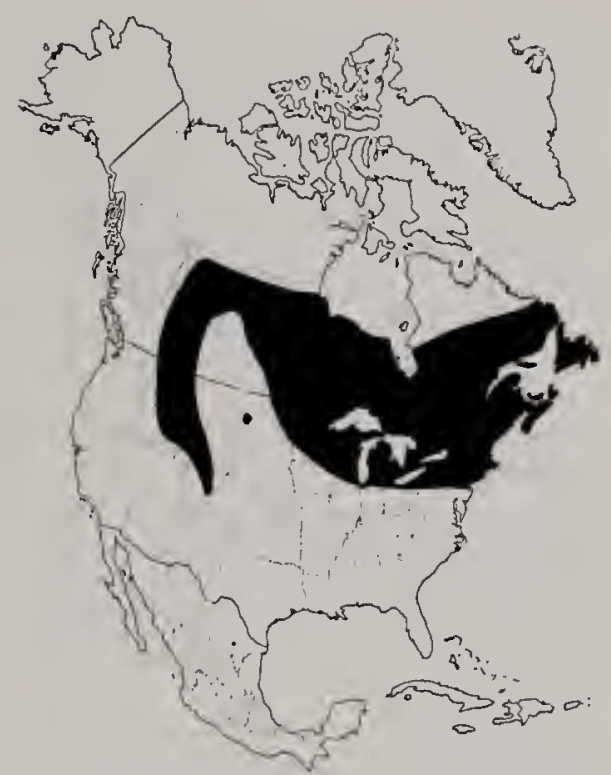

Fig. 128.-Distribution of Chrysops frigidus in North America.

In Illinois the species is restricted to the northeast corner of the state.

Illinois Records.-Lake County, Chain O'Lakes State Park, Volo Bog Nature Preserve, Antioch; McHenry County, Moraine Hills State Park (3 miles S McHenry).

\section{Chrysops fulvistigma Hine}

Chrysops fulvistigma Hine (1904:55). Typelocality: North Carolina, Raleigh.

Small size ( $7 \mathrm{~mm})$; yellow and black; frontoclypeus black, occasionally with a short median pollinose stripe; thorax dark, nearly black, with gray pollen: abdomen yellow at base, black at apex, basal segment with large median black spot, second segment with two contiguous black triangles, their bases reaching posterior margin; wing pattern extremely faint. Male easily associated with female by abdominal markings and nearly obsolete wing pattern: frontoclypeus with pollinose stripe reaching half way to oral margin.

The nearly obsolete wing pattern easily separates this species from any other Chrysopss likely to be found in Illinois.

Immature stages are unknown.

C. fulvistigma is a southeastern species, 


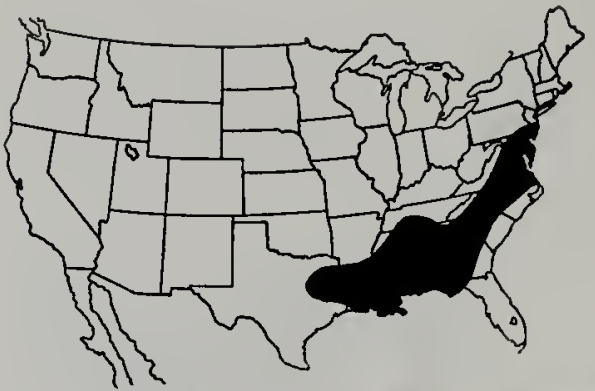

Fig. 129.-Distribution of Chrysops tulvistigma in North America.

extending from the western panhandle of Florida to New Jersey and west to eastern Texas (Fig. 129). As yet this species has not been collected in Illinois.

\section{Chrysops geminatus Wiedemann}

Chrysops geminatus Wiedemann (1828: 205). Type-locality: unknown.

Chrysops fallax Osten Sacken (1875:392).

Type-locality: New York, Tarrytown (lectotype).

Small to moderate size $(7 \mathrm{~mm})$; black and yellow; frontoclypeus shining yellow; abdominal marking usually not in form of stripes, but black markings occasionally reduced, appearing as broken rows of spots; apical spot broad (Fig. 54), nearly separated from crossband, covering nearly all of second submarginal cell; hyaline triangle large, extends well beyond second longitudinal vein; crossband broad, covering most of discal cell, narrowed posteriorly, reaching hind margin of wing; both basal cells hyaline; fifth posterior cell hyaline. Male with some dilute infuscation in both basal cells.

The larvae (Fig. 83) have been found in wet soil, plant debris, and moss along streams and ponds and in wet soil under trees (Pechuman 1972: Teskey 1969).

In Illinois adults appear from late June to early July.

C. geminatus is an eastern and southern species, extending from the panhandle of Florida to Maine and west to Arkansas and Wisconsin (Fig. 130). In Illinois this species has been collect-

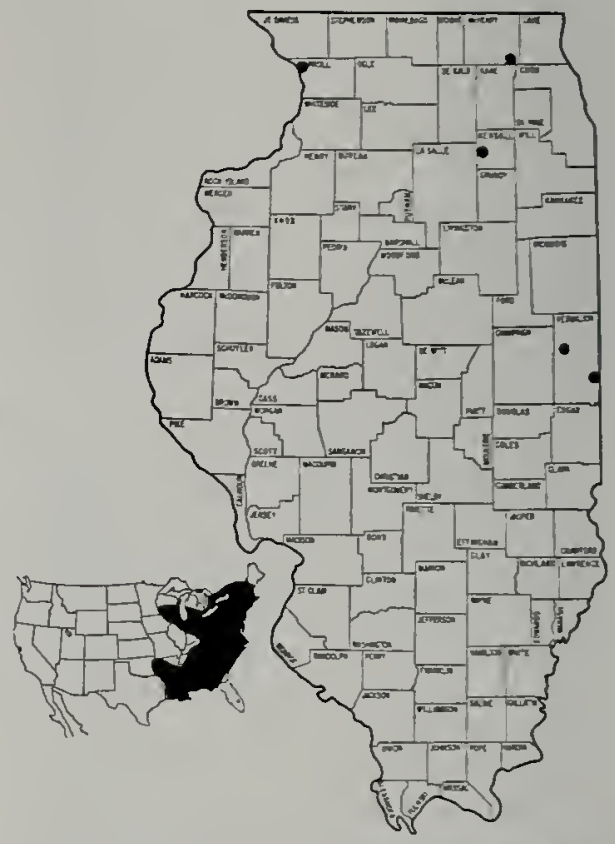

Fig. 130.-Distribution ol Chrysops geminatus in Illinois and North America.

ed in the northeastern third of the state (Fig. 130).

\section{Chrysops impunctus Kröber}

Chrysops impunctus Kröber (1926:301). Type-locality: Ontario. Port Stanley: Small to moderate size $(7.5 \mathrm{~mm})$ : yellow and black; frontoclypeus yellow; thorax greenish with black stripes; abdomen with basal two segments yellow: remaining segments black, segments 3 and 4 with median yellow stripe: apical spot broad (Fig. 55), covering nearly all of second submarginal cell, nearly separated from crossband; hyaline triangle large, extending well beyond second longitudinal vein; crossband broad, covering discal cell, reaching hind margin of wing: first basal cell with basal infuscation: second basal cell hyaline: fifth posterior cell diffusely infuscate. Male easily associated with female: yellow stripe on abdominal segments 3 and $t$ is broader than that in most females.

This species was previously considered a subspecies of $C$. geminatus.

Both sexes of this species are distin- 
guished from other Illinois Chrysops by the two completely yellow basal abdominal segments. Occasional specimens of geminatus have the spots on the second segment reduced to a vague shadow in the center of the segment. Rarely, specimens of impunctus show a trace of a dark marking on the second tergite, but it is at the apex of the segment.

Immature stages are unknowir.

In Illinois adults appear in mid-June and have been collected until late July.

C. impunctus is an eastern and southern species, extending from Louisiana to Delaware and west to Illinois (Fig. 131). This species has been collected in long series from Vermilion County, Illinois.

Illinois Records.-Douglas County, Walnut Point State Park ( 5 miles SE Hindsboro); Vermilion County, Kickapoo State Park, Forest Glen Forest Preserve ( 5 miles SE Westville), 2.8 miles E Oakwood.

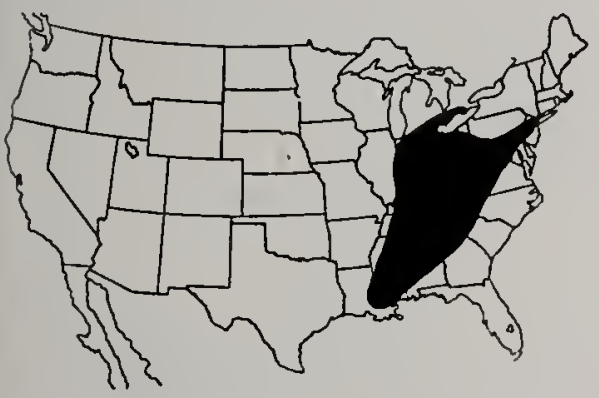

Fig. 131.-Distribution of Chrysops impunctus in North America.

\section{Chrysops indus Osten Sacken}

Chrysops indus Osten Sacken (1875:383). Type-locality: New York, Cayuga Lake.

Chrysops pilummus Kröber (1926:278). Type-locality: Ontario, Jordan.

Moderate size $(8 \mathrm{~mm})$; yellow and black; frontoclypeus shining yellow; frontal callus black; scutellum dark; abdomen with median row of rather large yellow triangles, hind margin of tergites narrowly yellow, lateral margins broadly yellow; apical spot broad
(Fig. 56), extending into second submarginal cell; hyaline triangle does not reach second longitudinal vein; crossband broad, covering discal cell, reaching hind margin of wing; first basal cell infuscate; second basal cell hyaline; fifth posterior cell almost completely infuscate: apical half of anal cell infuscate. Male with black areas much more extensive than in female; both basal cells and fifth posterior cell almost completely infuscated.

This species resembles $C$. macquarti in appearance, but the dark scutellum and the abdomen without stripes readily separate these two species.

The larvae (Fig. 100) have been found in mud and in plant debris and moss in a variety of semiaquatic habitats (Pechuman 1972; Teskey 1969).

In Illinois adults appear in late May and have been collected until late July.

C. indus is a northern and eastern species, extending from Virginia to Maine and west to Manitoba (Fig. 132). The range of this species may extend into Georgia. In Illinois this species has been collected in the northern part of the state (Fig. 132).

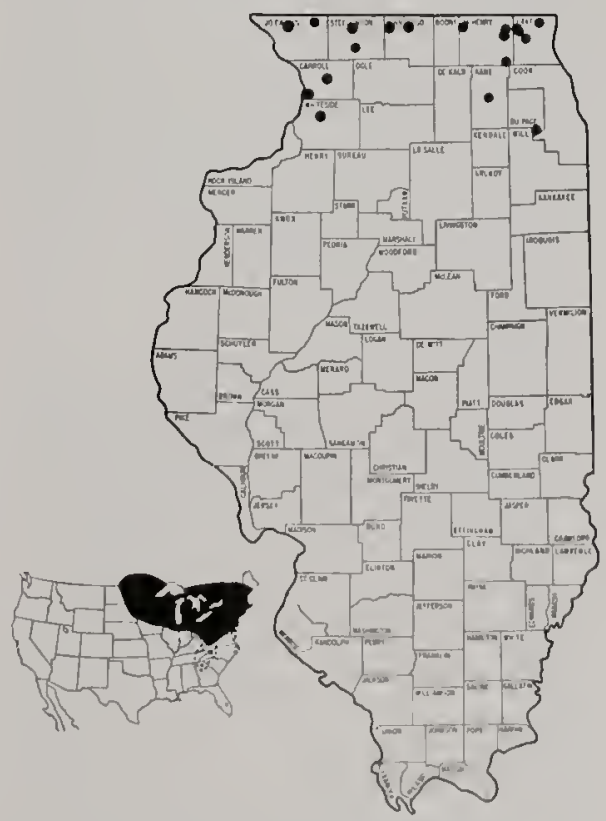

Fig. 132.-Distribution of Chrysops Indus in Illinois and North America. 


\section{Chrysops Iuteopennis Philip}

Chrysops luteopennis Philip (1936c:159).

Type-locality: Minnesota, Anoka County, Moore's Lake.

Moderate size $(8 \mathrm{~mm})$; dull yellow and black; frontoclypeus yellow, some specimens with small triangle of pollen below antennae; frontal callus yellow, darkened above (in one specimen callus wholly dark brown); black median stripes of abdomen joined on second tergite, sublateral stripes do not reach anterior margin of second tergite; wing membrane lightly tinted, pattern pale brown, not covering all of discal cell; hyaline triangle does not quite reach second longitudinal vein (Fig. 57). Male similar to female, but wing membrane, especially in anal area, more heavily tinted; apical spot slightly broader; triangular pollinose area on frontoclypeus reaches halfway to level of frontoclypeal pits.

The combination of a tinted wing membrane and brown wing pattern which does not completely cover the discal cell should separate this species from any other likely to be found in Illinois.

The larva of this species is unknown.

C. luteopennis is a rarely collected species of Chrysops known from only five localities in the north-central states and in southern Ontario (Fig. 133). Eventually it may be found in Illinois near Lake Michigan.

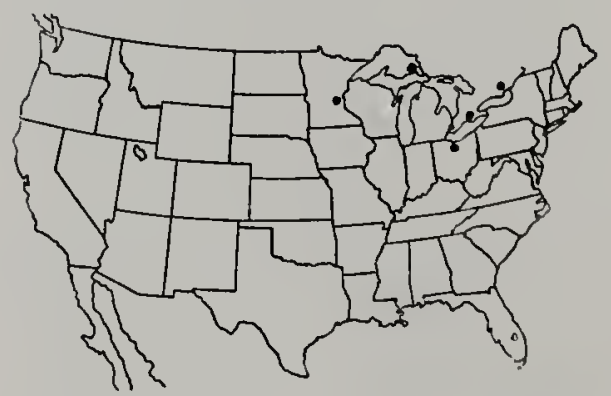

Fig. 133.-Distribution of Chrysops luteopennis in North America.

\section{Chrysops macquarti Philip}

Chrysops macquarti Philip (1961:161). Type-locality: Maryland, Catonsville.
Moderate size $(7.5 \mathrm{~mm})$; yellow and black; frontoclypeus shining yellow; frontal callus black or dark brown; thorax greenish gray in ground color; scutellum usually with considerable yellow; abdomen with yellow median stripe between two black stripes of varying width, laterally yellow; apical spot very broad (Fig. 58), extending into second posterior cell; hyaline triangle does not reach second longitudinal vein; crossband broad, covers discal cell, narrows posteriorly but reaches hind margin of wing; first basal cell infuscate; second basal cell hyaline; fifth posterior cell hyaline. Male generally darker than female with broader black abdominal stripes and often dark scutellum; second basal cell half or more infuscated.

This species resembles $C$. indus but is smaller and can be readily separated from indus by the characters in the key.

The larvae (Fig. 89) are usually found in saturated soils bordering sluggish streams (Pechuman 1972; Teskey 1969).

In Illinois adults appear in mid-June and have been collected until early August.

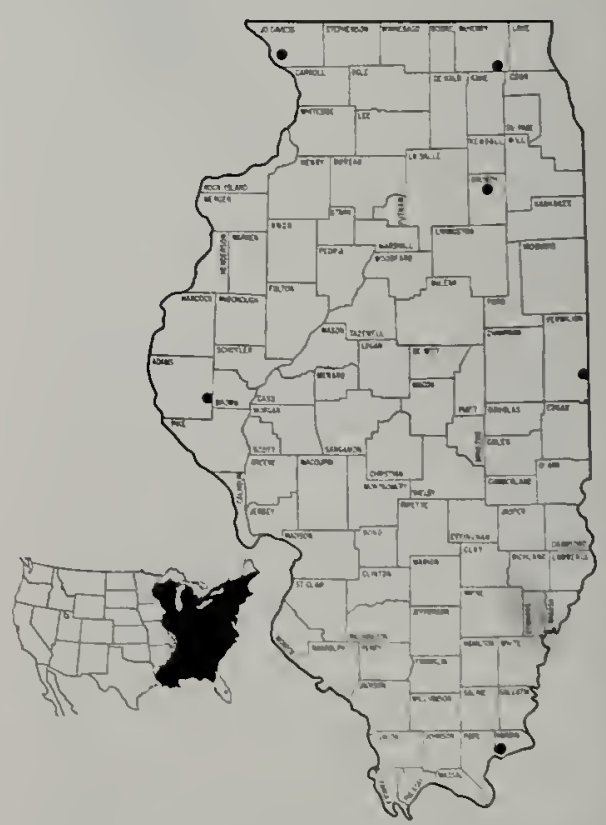

Fig. 134.-Distribution of Chrysops macquart। in Illinois and North America. 
C. macquarti is a widespread eastern species, extending from northern Florida to Maine and west to Wisconsin and Louisiana (Fig. 134). In Illinois this species is rare, having been collected from only five localities (Fig. 134).

\section{Chrysops mitis Osten Sacken}

Chrysops mitis Osten Sacken (1875:374).

Type-locality: Canada, Hudson Bay (lectotype).

Large species $(9.5 \mathrm{~mm})$; black; frontoclypeus with median pollinose stripe; pleura with grayish or pale yellowish pile; abdomen entirely dark; no apical spot or hyaline triangle (Fig. 59); crossband broad, covering discal cell, narrowly or not at all reaching hind margin of wing; basal half of both basal cells infuscate; base of fifth posterior cell infuscate. Male with considerable dilute infuscation in anal area of wing.

This species is close to $C$. ater in general appearance, and some specimens can scarcely be differentiated. The characters in the key will generally separate these two species.

The egg mass is in three tiers, resembling those of $C$. ater and $C$. cincticornis. The larvae (similar to Fig.

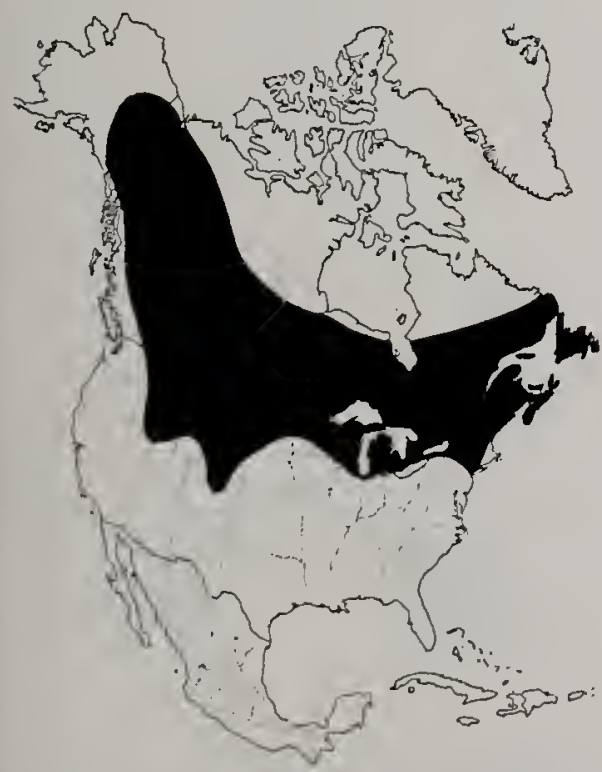

Fig. 135.-Distribution of Chrysops mitis in North America.
103) have been collected on the edges of ponds and streams and in swamps, usually in a highly organic substrate (Peclumman 1972; Teskey 1969).

In Illinois adults appear in early June and have been collected only until the middle of June.

C. mitis is a northern species, extending from New York to Labrador and west to ldaho and Alaska (Fig. 135). In Illinois this species is restricted to the northeast corner of the state.

Illinois Records.-Kankakee County, Wichert; Lake County, Antioch, Sand Lake.

\section{Chrysops moechus Osten Sacken}

Chrysops moechus Osten Sacken (1875:

387). Type-locality: District of Columbia (lectotype).

Moderate size $(7.5 \mathrm{~mm})$; yellow and black; frontoclypeus shining yellow; frontal callus usually black; thorax greenish in ground color; black markings of abdomen usually in form of stripes; apical spot very broad (Fig. $60)$, covering first posterior cell; hyaline triangle extremely small but regular in outline; crossband broad, covering discal cell, extending to hind margin of wing; first basal cell infuscate; second basal cell hyaline; fifth posterior cell mostly hyaline. Male black; wings almost entirely infuscated except for small hyaline triangle.

The body pattern of this species is variable, the black abdominal stripes of some specimens being reduced to a series of dashes; in others the stripes are extensive and the entire insect appears quite dark. This species is very distinctive from other species of Chrysops, particularly in the wing pattern.

Eggs are laid on the underside of leaves of trees overhanging streams, sometimes many feet above the water. Pechuman (1972) observed oviposition only over moving water. The egg mass is unusual in that the individual eggs are deposited almost at right angles to the leaf (Fig. 14) and do not overlap each other as is usual in Chrysops egg masses (Fig. 12, 13). The larvac (Fig. 82) liave been collected in wet mud, often un- 


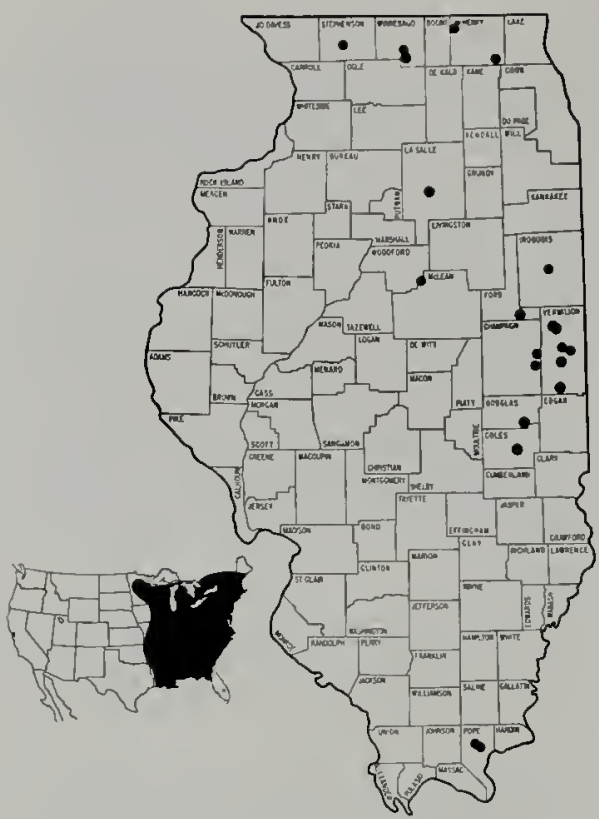

Fig. 136.-Distribution of Chrysops moechus in Illinois and North America.

der water, along streams (Pechuman 1972; Teskey 1969).

In Illinois adults appear in early June and have been collected until early August. The male is black and is rather frequently collected from leaves of trees overhanging streams (Pechuman 1972).

C. moechus is an eastern species, extending from the Florida panhandle to Maine and west to Mimnesota and Louisiana (Fig. 136). In Illinois (Fig. 136) this species has been collected in the northeastern third of the state and in Pope County in southern lllinois.

\section{Chrysops montanus Osten Sacken}

Chrysops montanus Osten Sacken (1875: 382). Type-locality: New York, Catskill Mountain House (in Greene County).

Moderate size $(8 \mathrm{~mm})$; black and yellow; frontoclypeus shining yellow; frontal callus normally dark but sometimes brownish; scutellum normally dark; abdomen with geminate black spot, often with sublateral black spot on second tergite, and four rows of spots on third, fourth, and fifth tergites; apical spot variable but usually broad. covering most of second submarginal cell (Fig. 61); hyaline triangle large, reaching second longitudinal vein; crossband broad, covering discal cell, reaching hind margin of wing; first basal cell partly infuscate; second basal cell nearly hyaline; fifth posterior cell partly infuscate. Male with yellow areas usually much reduced; both basal cells partly infuscated.

Some specimens lack the small black lateral spots on the second abdominal segment or have them much reduced. The size and shape of the apical spot is also subject to considerable variation.

The larvae (Fig. 91) have been collected in sand and organic material on the edges of ponds and lakes (Pechuman 1972; Teskey 1969).

In Illinois adults appear in late May and have been collected until late August.

C. montanus is an eastern and northcentral species, extending from southern Florida to New Brunswick and west to Manitoba and eastern Texas (Fig. 137). This species has been col-

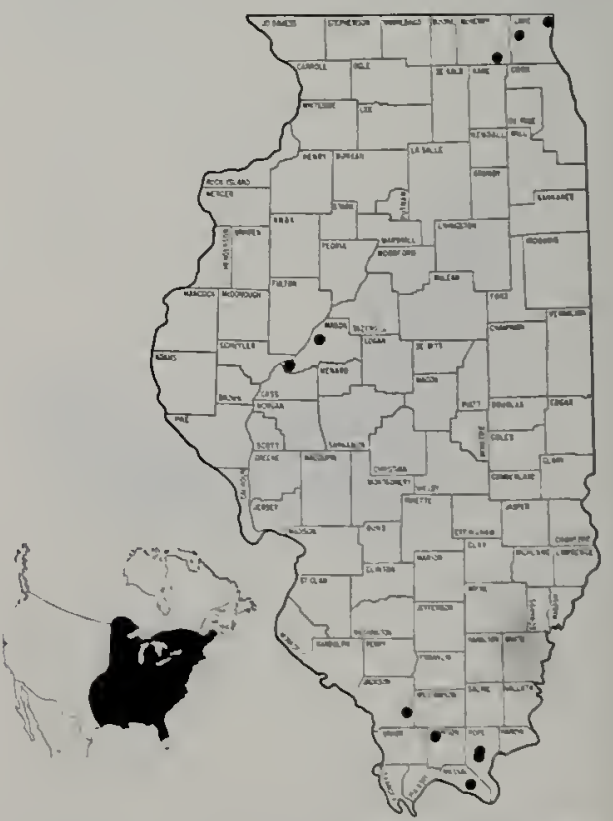

Fig. 137.-Distribution of Chrysops montanus in Illinois and North America. 
lected infrequently in southern and northern Illinois (Fig. 137).

\section{Chrysops niger Macquart}

Chrysops niger Macquart (1838:165).

Type-locality: North America.

Moderate size $(7.5 \mathrm{~mm})$; black; frontoclypeus without median pollinose stripe; bare area of vertex interrupted by pollen; sublateral thoracic stripes dull or obsolete; apical spot and hyaline triangle absent (Fig. 62); crossband broad, covering discal cell, narrowed posteriorly, reaching hind margin of wing; first basal cell infuscate; second basal cell hyaline; fifth posterior cell hyaline. Male with both basal cells largely infuscated. Face with considerable yellow in both sexes.

The combination of a hyaline second basal cell, saturate crossband, and largely yellow face separates this species and its sibling species, $C$. calvus, from other dark Chrysops. It is separated from calvus by the characters in the key. Some specimens have a small spot at the bifurcation of the third longitudinal vein. The anal area of the wing is sometimes dilutely infuscated.

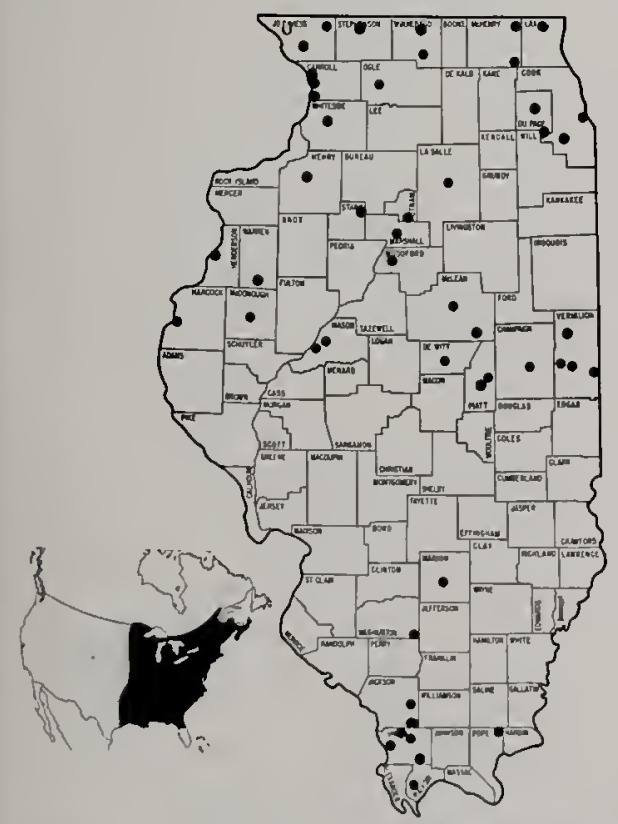

Fig. 138.-Distribution of Chrysops niger in IIIinois and North America.
The larvae (Fig. 93) seem tolerant of many conditions and have been collected from such varied situations as stagnant mud and plant debris on the edge of a pool, mud on the banks of a small brook, wet soil under trees, sphagnum bogs, and the shores of lakes (Pechuman 1972; Teskey 1969; Tidwell 1973).

In Illinois adults appear in early April and have been collected until late June.

C. niger is an eastern and central species, extending from northern Florida to Nova Scotia and west to Minnesota and eastern Texas (Fig. 138). In 1llinois this species is found throughout the state (Fig. 138).

\section{Chrysops pikei Whitney}

Chrysops pikei Whitney (1904:205). Typelocality: Missouri, Pike County.

Rather small size $(7 \mathrm{~mm})$; yellow and black; frontoclypeus shining yellow; frontal callus black; thorax greenish yellow in ground color; abdomen with black stripes, sublateral ones quite short; apical spot broad (Fig. 63), extending into first posterior cell; hyaline triangle reaches second longitudinal vein; crossband broad, covering discal cell, reaching hind margin of wing; first basal cell infuscate; second basal cell hyaline; fifth posterior cell partly infuscate. Male with second basal cell partly infuscated.

This species is rather distinctive and is readily separated from other species by the characters given in the key.

The egg mass is in more than one tier, resembling a small Tabanus egg mass. The larvae (Fig. 84) are found in debris and in the banks of ponds and streams (Jones \& Bradley 1924; Pechuman 1972; Teskey 1969; Tidwell 1973).

In 1llinois adults appear in micl-May and have been collected until early September.

C. pike is a southeastern and central species, extending from northern Florida to Virginia and west to South Dakotil and eastern Texas (Fig. 139). Disjunct 


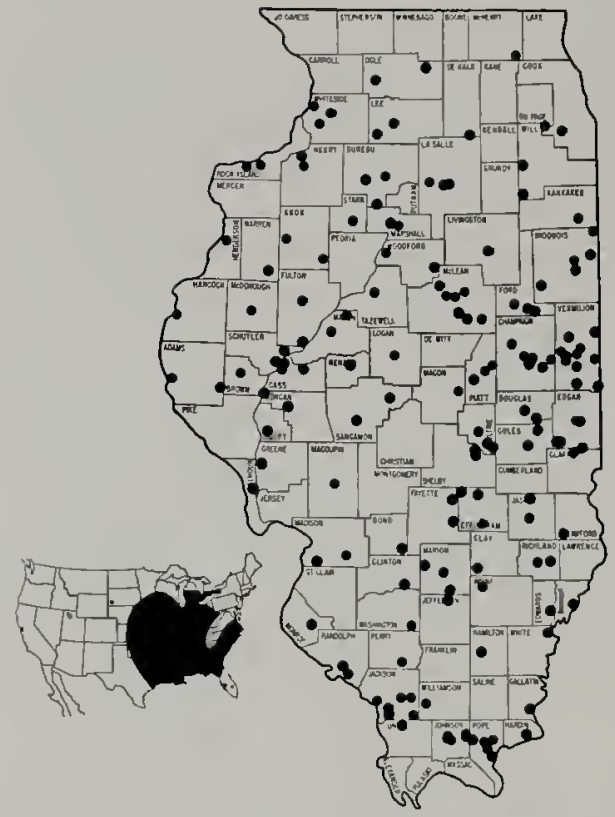

Fig. 139. - Distribution of Chrysops pikel in Illinois and North America.

populations are found in southwestern South Dakota and southern Florida. This species is widespread throughout Illinois (Fig. 139).

\section{Chrysops pudicus Osten Sacken}

Chrysops pudicus Osten Sacken (1875:

381). Type locality: Massachusetts (lectotype).

Moderate size $(7.5 \mathrm{~mm})$; black and yellow; frontoclypeus shining yellow; frontal callus yellow or fuscous; dark spot under scutellum; abdominal markings not in form of stripes; apical spot covers apical third of second submarginal cell; hyaline triangle broad, usually reaching second longitudinal vein; crossband broad, covering discal cell, reaching hind margin of wing; both basal cells hyaline; fifth posterior cell hyaline (Fig. 64): hind femora usually dark at base. Male with both basal cells partly infuscated.

$C$. pudicus belongs to the group which includes $C$. callidus, $C$. sackeni, and $C$. dimmocki and may be separated from them by the characters given in the key; the apical spot of pudicus is sub- ject to some variation but is always wider than it is in callidus and usually falls between those of sackeni and dimmocki.

Larvae have been taken from wet soil along a roadside ditch (Pechuman 1972).

In Illinois adults appear in early May and have been collected until mid-September.

C. pudicus is a southeastern species, extending from southern Florida to Massachusetts and west to Illinois and eastern Texas (Fig. 140). Disjunct populations have been examined from Wisconsin, Michigan-Indiana, New York-Ontario, and Nova Scotia. In Illinois this species is found in the southern fourth of the state (Fig. 140).

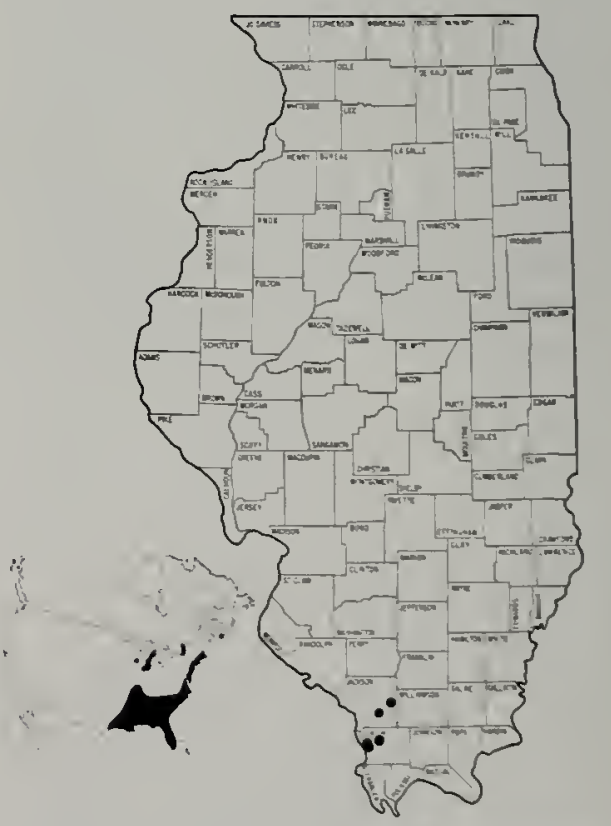

Fig. 140.-Distribution of Chrysops pudicus in Illinois and North America.

\section{Chrysops reicherti Fairchild}

Chrysops reicherti Fairchild (1937:60).

Type-locality: Florida, Jefferson County: Monticello.

Large size $(9.0 \mathrm{~mm})$; yellow and brown; frontoclypeus shining yellow; thorax grayish brown with fuscous stripes; abdomen pale grayish brown, 
tergites 2-6 with lateral brown band; apical spot broad (Fig. 65), covering second submarginal cell; hyaline triangle does not reach second longitudinal vein; crossband broad, covering discal cell, reaching hind margin of wing; first and second basal cells partly infuscate; fifth posterior cell infuscate. Male with apical spot more extensive, often nearly surrounding hyaline triangle, which may be reduced to pale band or series of spots; both basal cells infuscated on most of basal half.

This species is related to flavidus but can be readily separated from flavidus by the characters given in the key.

Larvae (Fig. 98) have been collected from wet mud and organic debris in ponds and small lakes (Goodwin 1972; Tidwell 1973).

In lllinois adults appear in mid-July and have been collected until late August.

C. reicherti is a southeastern species, extending from southern Florida to Delaware and west to Illinois and eastern Texas (Fig. 141). In lllinois this species has been collected only in the

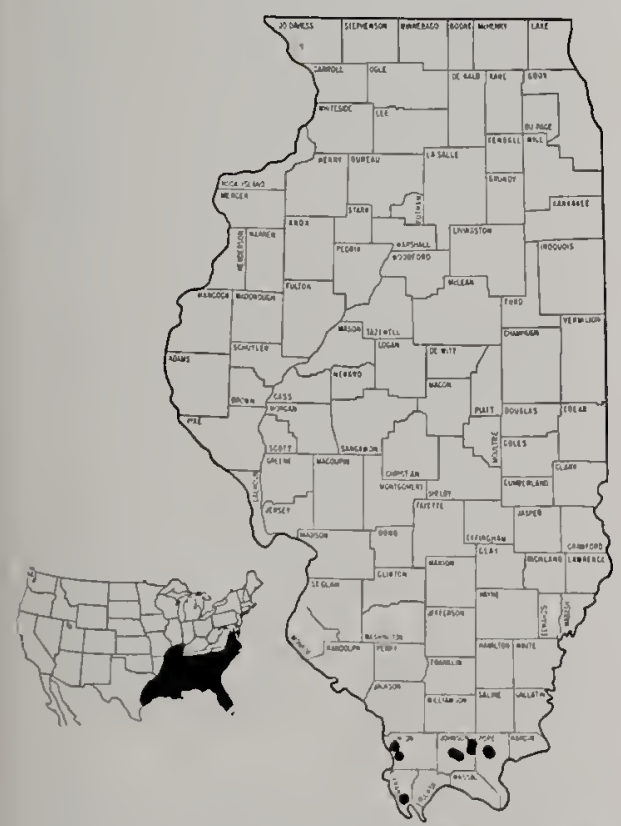

Fig. 141.-Distribution of Chrysops relchertl in Illinois and North America. southernmost part of the state (Fig. 141).

\section{Chrysops sackeni Hine}

Chrysops sackeni Hine (1903:42). Typelocality: Ohio, Sandusky.

Moderate size $(8.5 \mathrm{~mm})$; black and yellow; frontoclypeus shining yellow; frontal callus usually yellow, often bordered with black or brown, occasionally black; abdominal markings not in forn of stripes, black spot on second segment nearly joins with that on first segment, second and third sternites with black sublateral spots; apical spot narrow (Fig. 66), extending partly into second submarginal cell, at its origin slightly wider than marginal cell; hyaline triangle broad, not reaching second longitudinal vein; crossband broad, covering discal cell, not reaching hind margin of wing; both basal cells hyaline; fifth posterior cell partly infuscate. Male usually with pale markings less extensive; both basal cells partly infuscated.

C. sackeni often flies with C. callidus, and occasional specimens are difficult

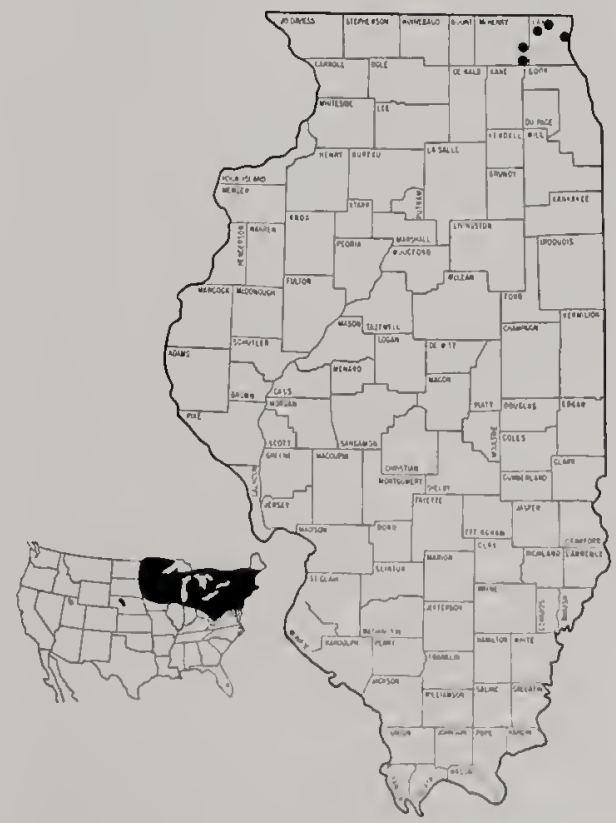

Fig. 142.-Distribution of Chrysops sackenl in Illinois and North America. 
to separate from that species. In cases of doubt, the shape of the frontal callus is usually the best character to inspect; the callus of $C$. callidus is narrow and black, whereas in $C$. sackeni it is higher in proportion to its width and is often yellow or brown.

The larvae (Fig. I05) have been collected in mud on the edges of permanent and temporary ponds, along stream margins, in swamps, and in organic material on the edge of salt marshes (Pechuman 1972; Teskey 1969). The egg mass resembles that of C. callidus.

In Illinois adults appear in mid-June and have been collected until midSeptember.

C. sackeni is a northeastern and northcentral species, extending from Delaware to Maine and west to lowa and Manitoba (Fig. 142). A disjunct population has been examined from western Nebraska. In Illinois this species has been collected in the northeastern part of the state (Fig. I42).

\section{Chrysops separatus Hine}

Chrysops separatus Hine (1907:228). Typelocality: North Carolina, Raleigh.

Moderate size $(8 \mathrm{~mm})$; thorax, abdomen, and frontoclypeus black, the latter with broad pollinose stripe extending three-fourths its length; first basal cell wholly infuscated (Fig. 67), second basal cell clear; apical spot not joined to crossband. Male has both basal cells and discal cell outlined in black with centers clear; pollinose stripe of frontoclypeus extends to oral margin.

No other wholly black Chrysops likely to be found in Illinois has the combination of an apical spot and a pollinose stripe on the frontoclypeus.

The larva of this species is unknown.

In Illinois adults have been collected only during mid-May.

C. separatus is a southeastern species, extending from Georgia to Maryland and west to Illinois and northeastern Mississippi, with an apparently disjunct population extending from southwestern Mississippi to eastern Texas and

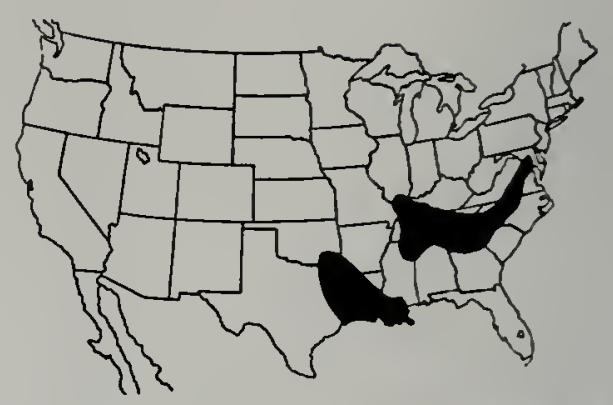

Fig. 143.-Distribution of Chrysops separatus in North America.

Oklahoma (Fig. 143). In Illinois this species is known only from the southern third of the state.

Illinois Records.-Perry County, Du Quoin; Pope County, 4 miles NNW Golconda, Lusk Creek (3 miles SE Eddyville).

\section{Chrysops sequax sequax Williston}

Chrysops sequax sequax Williston (I887:

I33). Type-locality: western Kansas.

Moderate size $(8.0 \mathrm{~mm})$; yellow and black; frontoclypeus shining yellow with large black spot on each side; thorax grayish green in ground color with dark stripes; abdomen yellow with black stripes; apical spot broad (Fig. 68), covering all of second submarginal cell; hyaline triangle reaches second longitudinal vein; crossband broad, covering discal cell, reaching hind margin of wing; first basal cell completely infuscate; second basal cell hyaline; fifth posterior cell partly infuscate along lateral margins. Male with black abdominal stripes broader than in female; second basal cell infuscate; fifth posterior cell infuscate.

$C$. sequax resembles the related species $C$. beameri and $C$. pikei, but the characters used in the key usually present no difficulty. Rarely sequax has a brown or yellowish frontal callus, and in this case it may be separated from beameri by the large black spots flanking the frontoclypeus.

The larvae (Fig. 92) have been collected from soft, slimy muck on the margin of a livestock watering pond (Teskey \& Burger 1976). 


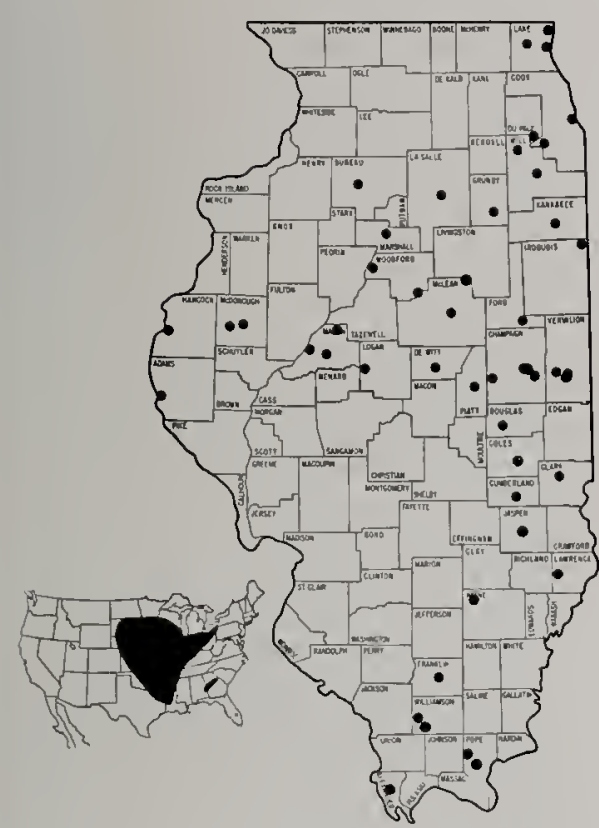

Fig. 144.-Distribution of Chrysops sequax sequax in Illinois and North America.

In Illinois adults appear at the beginning of July and have been collected until early September.

C. sequax sequax is a central subspecies, extending from Louisiana to Pennsylvania and west to western South Dakota (Fig. 144). A disjunct population has been examined from Georgia and Alabama. In Illinois this subspecies is widely distributed throughout the state (Fig. 144).

\section{Chrysops sequax tau Philip}

Chrysops sequax tau Philip (1955:113).

Type-locality: Illinois, Golconda.

Moderate size $(8.0 \mathrm{~mm})$; this form is separated from the nominate form by the presence of a narrow, sometimes broken, stripe of pollen on the frontoclypeus; there is also a tendency for the apical spot to be less extensive and for the frontal callus to be partly brown or yellowish. Specimens and biological studies probably will be needed to determine the true status of tau. The male is unknown.

The larva of this subspecies is unknown.

In Illinois adults appear in late July

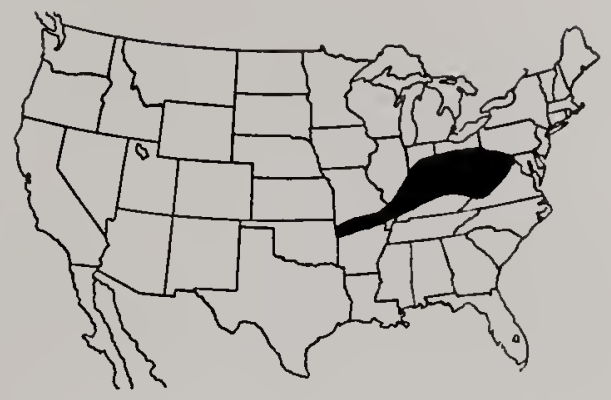

Fig. 145.-Distribution of Chrysops sequax tau in North America.

and have been collected until early August.

C. sequax tau is an east-central subspecies, extending in a narrow band from Virginia west to Missouri and Arkansas (Fig. 145). In Illinois this subspecies has been collected only in the southeastern part of the state.

Illinois Records.-Lawrence County, Red Hills State Park; Pope County, Golconda, Lusk Creek.

\section{Chrysops striatus Osten Sacken}

Chrysops striatus Osten Sacken (1875: 391). Type-locality: (lectotype, no locality data).

Moderate size $(8.0 \mathrm{~mm})$; yellow and black; frontoclypeus shining yellow; frontal callus usually black or brown, thorax greenish in ground color; abdomen with black stripes, median pair usually united on second tergite; apical spot broad (Fig. 69), usually covering only about half of second submarginal cell; hyaline triangle does not reach second longitudinal vein; crossband broad, covering discal cell, narrowed posteriorly but reaches hind margin of wing; first basal cell infuscate; second basal cell hyaline; fifth posterior cell mostly hyaline. Male with yellow areas reduced; second basal cell largely infuscated.

This species often flies with $C$. aberrans, which it resembles, but the two forms can be separated by the characters given in the key.

Larvae (Fig. 104) have been collected from mud on the edge of streams. They are probably found also in the 
cattail swamps where adults are common (Pechuman 1972; Teskey 1969).

In lllinois adults appear in late June and have been collected until mid-July.

C. striatus is a north-central and northeastern species, extending from Massachusetts to Maine and west to Manitoba (Fig. 146). In Illinois this species has been collected in four counties in the northeast corner of the state (Fig. 146).

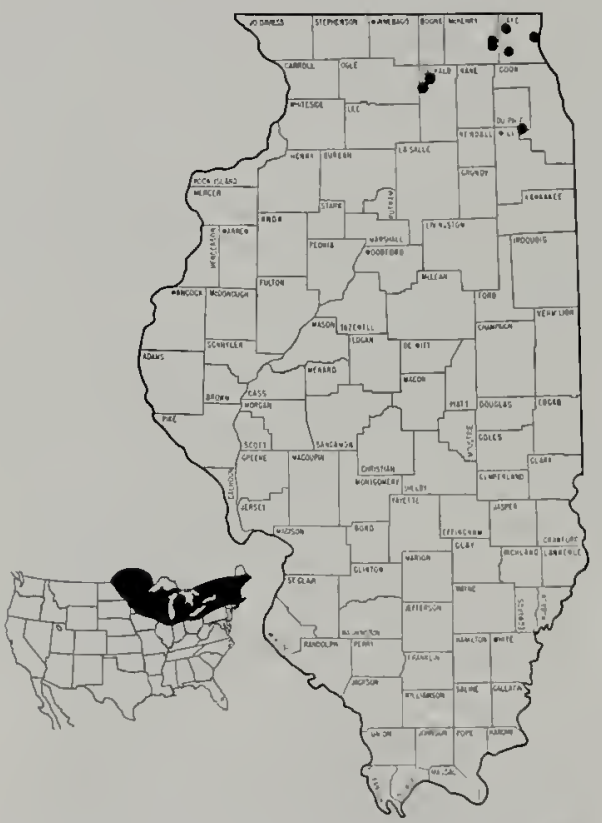

Fig. 146.-Distribution of Chrysops striatus in Illinois and North America.

\section{Chrysops univittatus Macquart}

Chrysops univillatus Macquart (1855:56). Type-locality: Maryland, Baltimore. Chrysops wiedemanni Kröber (1926:267).

Type-locality: (syntypes from several localities in Canada and the United States).

Chrysops fraternus Kröber (1926:328).

Type-locality: unknown.

Rather small size ( $7 \mathrm{~mm})$; black or dark brown; frontoclypeus shining yellow, often blackish laterally, abdonen with median yellowisl stripe, sometimes similar shorter sublateral stripes; apical spot broad and nearly separated from crossband (Fig. 70); hyaline tri- angle almost reaches anterior margin of wing; crossband broad, covering most of discal cell, narrowed posteriorly but reaches hind margin of wing; both basal cells and fifth posterior cell hyaline. Male with first basal cell infuscated.

Pechuman (1957) called this species C. wiedemanni Kröber. Since that time it has been shown (Philip 1961) that the correct name is univittatus, and the species called univittatus by various workers before 1961 is now known as $C$. macquarti Philip. The name $C$. obsoletus has also been applied to unizittatus, but this name properly belongs to a quite unrelated species.

The body coloration of $C$. univittatus is extremely variable. The abdominal pattern varies from three distinct yellow stripes to only a trace of a median stripe.

Larvae (Fig. 97) have been found in wet soil and plant debris along both sluggish and swift streams, in mud on the shores of ponds and lakes, and in marshes (Pechuman 1972; Teskey 1969).

In 1 llinois adults appear in early

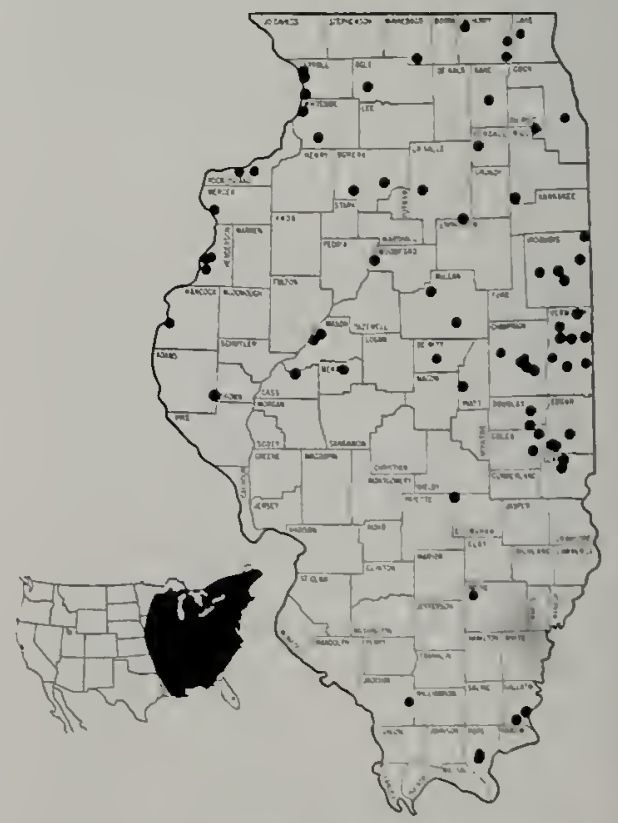

Fig. 147.-Distribution of Chrysops unlvittatus in Illinois and North America. 
May and have been collected until late August.

C. unizittatus is an eastern and central species, extending from the panhandle of Florida to New Brunswick and west to Minnesota and Louisiana (Fig. 147). This is an abundant and widespread species in Illinois (Fig. 147).

\section{Chrysops upsilon Philip}

Chrysops upsilon Philip (1950a:458). Typelocality: Georgia, Millen.

Moderate size $(8 \mathrm{~mm})$; black and yellow; frontoclypeus brown with yellow in center and short median pollinose stripe; frontal callus black; thorax grayish green in ground color; scutellum dark; abdomen dark brown to black with broad yellow median stripe and short sublateral stripes; apical spot broad (Fig. 71), covering most of the second submarginal cell; hyaline spot generally does not reach second longitudinal vein except as subhyaline streak; crossband broad, covering discal cell, reaching hind margin of wing; infuscation of costal cell paler than that of crossband; both basal cells and fifth posterior cell hyaline. Male with pollinose stripe on frontoclypeus more extensive than in female, often reaching nearly to oral margin; first basal cell infuscated.

Among Illinois Chrysops, upsilon is likely to be confused only with $C$. univittatus, which lacks pollen on the frontoclypeus; in cases where the pollen is indistinct, the best character for separation is the color of the costal cell, which is paler than the crossband in upsilon.

Larvae are unseparable from those of C. univittatus.

In Illinois adults appear in early June and have been collected until mid-September.

C. upsilon is a southeastern species, extending from the panlandle of Florida to Delaware and west to Illinois and eastern Texas (Fig. 148). In 1llinois this species has been collected in the southern part of the state (Fig. 148).

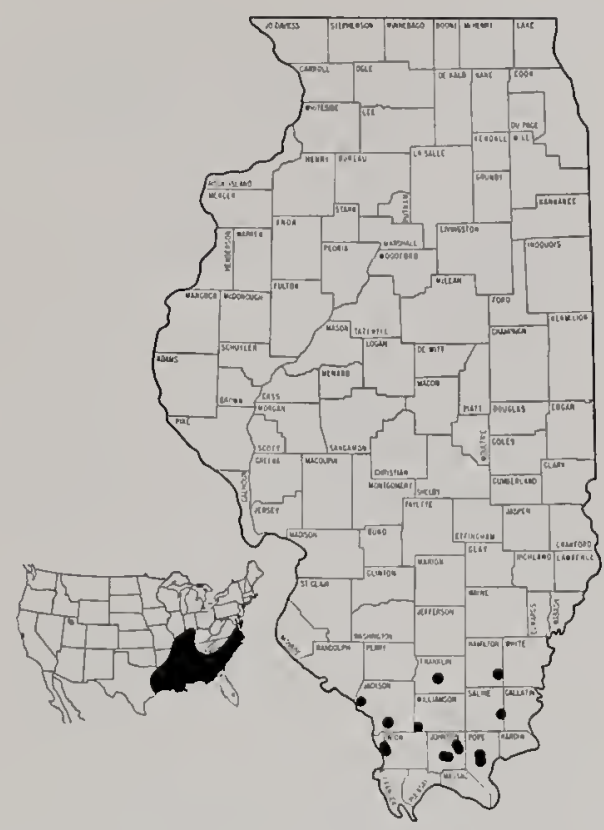

Fig. 148.-Distribution of Chrysops upsllon in Illinois and North America.

\section{Chrysops vittatus Wiedemann}

Chrysops vittatus Wiedemann (1821:56).

Type-locality: North America.

Chrysops areolatus Walker (1848:197).

Type-locality: New York.

Chrysops lineatus Jaennicke (1867:334).

Type-locality: Illinois.

Chrysops ornatus Kröber (1926:328).

Type-locality: Ontario, Jordan.

Moderate size $(8 \mathrm{~mm})$; yellow and black; frontoclypeus shining yellow; frontal callus yellow; thorax yellow in ground color; scutellum yellow; abdomen with black stripes; apical spot broad (Fig. 72), covering second submarginal cell; hyaline triangle does not reach second longitudinal vein; crossband very broad, covering discal cell, reaching hind margin of wing; first basal cell infuscate; second basal partly infuscate; fifth posterior cell largely infuscated. Male with yellow areas reduced; second basal cell largely infuscated.

This species is rather distinctive from other species of Chrysops and is readily separated by the characters in the keys.

The larvae (Fig. 85) have been col- 
lected in wet soil and plant debris from the edges of streams, ponds, and lakes, as well as from saturated soil under trees (Pechuman 1972; Teskey 1969).

In Illinois adults appear in mid-June and have been collected until late August.

C. vittatus is an eastern and central species, extending from northern Florida to Nova Scotia and west to North Dakota and Eastern Texas (Fig. 149). This species is abundant and widely distributed throughout lllinois (Fig. 149).

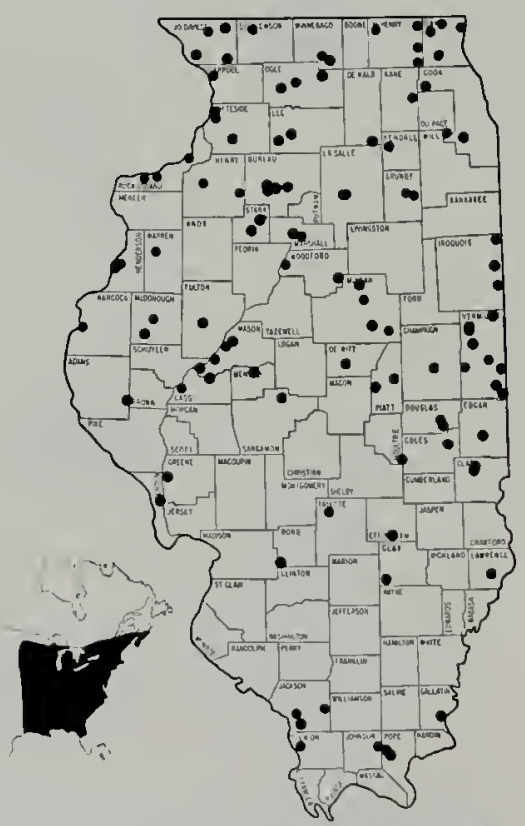

Fig. 149.-Distribution of Chrysops vittatus in Illinois and North America.

\section{Silvius Meigen \\ Silvius quadrivittatus (Say)}

Chrysops quadrivittatus Say (1823:33). Type-locality: near the Rocky Mountains.

Moderate size $(8 \mathrm{~mm})$; grayish species; basal callus diamond shaped; wings (Fig. 73) clear with small but distinct spots on crossveins, bifurcation and subapically on second longitudinal $\left(R_{2}+3\right)$, both branches of third longitudinal ( $R_{4}$ and $R_{5}$ ), and both branches of fourth longitudinal $\left(\mathrm{M}_{1}\right.$ and $\mathrm{M}_{2}$ ) veins, occasionally some subapical spots obsolete; legs mostly yellow; abdomen with four rows of dark spots. Male similar, but abdomen with yellowish cast.

Larvae (Fig. 111) have been found in damp silty soil overlain by grass and vegetable debris on the steep banks of desert rivers (Burger 1977).

In Illinois adults appear in mid-June and have been collected until mid-August.

$S$. quadrivittatus is a central and southwestern species, extending from Mississippi to Illinois and west to Montana, California, and Mexico (Fig. 150). 1n Illinois this species has been collected only in the western part of the state (Fig. 150).

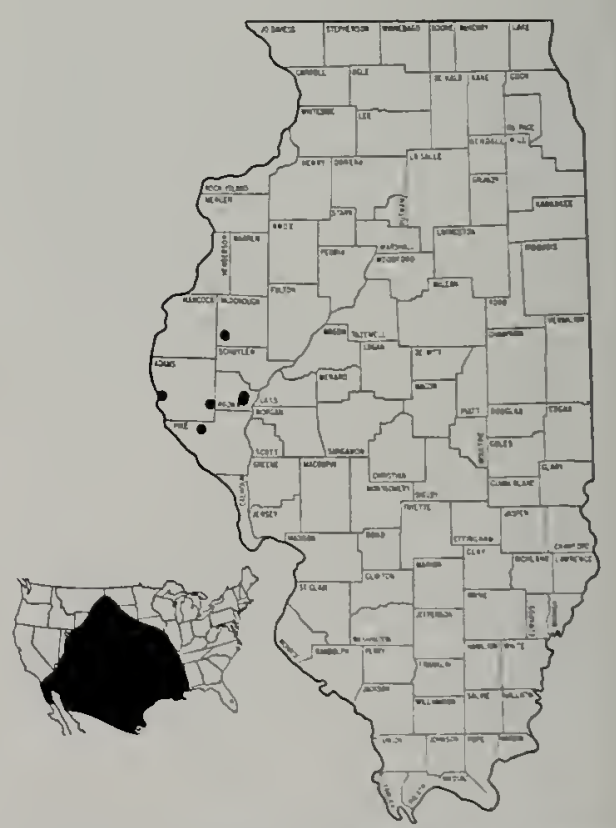

Fig. 150.-Distribution of Sllvius quadrivittatus in Illinois and North America.

Neochrysops Walton Neochrysops gIobosus Walton

Neochrysops globosus Walton (1918:192). Type-locality: Maryland, Cabin John Bridge. 
This genus is based on one rarely collected species.

Small size $(8.5 \mathrm{~mm})$; frontal callus large, oval, dark brown; frontoclypeus yellow with dark spot on each side and triangular area of pollen below antennae; antennae slender and elongate; thorax yellow with three shining black stripes, center one extending onto scutellum; wing (Fig. 74) rather uniformly infuscated with spur on an indication of one at bifurcation of third longitudinal vein; abdomen yellow, globose, wider than thorax, with double row of large black spots on tergites 1-5 with stiff black hairs laterally, especially heavy on segments 3 and 4 . Male holoptic, closely resembles female; abdomen less globose, scarcely wider than thorax; frontoclypeus with yellow pollinose stripe reaching half way to oral margin. The male has previously been unknown, but the only specimen seen from Illinois was a male.

The globose abdomen and other characters mentioned here and in the key to genera distinguish this species from any other lllinois tabanid.

The immature stages are unknown, and little is known about the habits of this species.

In Illinois adults have been collected only in early June.

$N$. globosus is a rare species, collected mostly as single specimens in Maryland, Delaware, Alabama, Mississippi, Tennessee, and Illinois (Fig. 15I).

Illinois records.-Pulaski County, Wetaug.

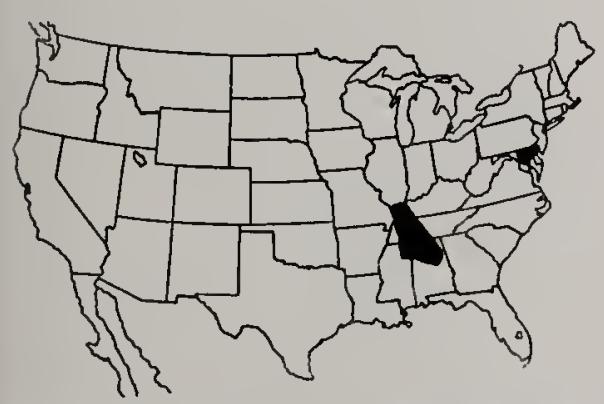

Fig. 151.-Distribution of Neochrysops globosus in North America.
Diachlorus Osten Sacken Diachlorus ferrugatus (Fabricius)

Chrysops ferrugatus Fabricius (1805:111). Type-locality: Carolina.

Tabanus americanus Palisot de Beauvois (1819:222). Type-locality: United States. Name preoccupied (Forster 1771).

Diabasis ataenia Macquart (1838:156).

Type-locality: Carolina.

Chrysops approximans Walker (1848:198).

Type-locality: Florida.

Chrysops convergens Walker (1848:198).

Type-locality: Honduras.

Tabanus rondanii Bellardi (1859:68).

Type-locality: Mexico.

Moderate size $(8 \mathrm{~mm})$; yellowish brown; first antennal segment scarcely longer than wide; third antennal segment without dorsal angle; median callus a narrow line; eyes bare; ocellar tubercle absent; frons higher than broad; abdomen yellowish, caudal segments brown; basicosta bare; wings pale brown; apical spot broad, dark brown; fore tibiae swollen; hind tibiae without apical spurs. The male is readily associated with the female.

Larvae (Fig. 110) have been found associated with root mats of woody plants in shaded areas (Jones \& Anthony 1964) in swantps and bogs and at the edges of lakes and streams.

Diachlorus ferrugatus is a southeastern species, extending from Florida to New Jersey and west to eastern Texas, with a disjunct population in northeast lndiana (Fig. 152). It is also found in

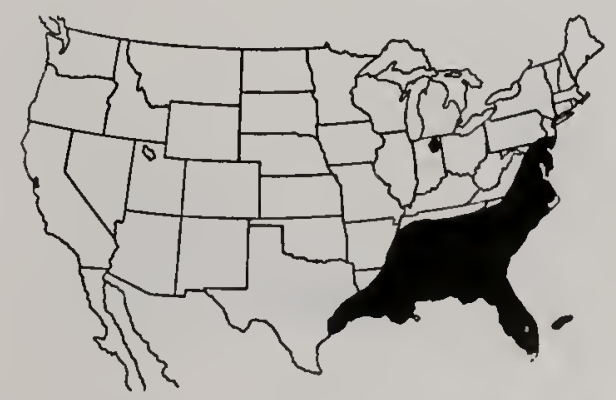

Fig. 152.-Distribution of Diachlorus ferrugatus in North America. 
Yucatan, Central America, and Grand Bahama Island. As yet this species has not been collected in 1llinois although specimens have been examined from Indiana.

\section{ChIorotabanus Lutz Chlorotabanus crepuscularis} (Bequaert)

Tabanus crepuscularis Bequaert (1926: 234). Type-locality: United States.

Tabanus flavus Macquart (1834:200).

Type-locality: United States. Name preoccupied (Wiedemann 1828).

Stout species $(12 \mathrm{~mm})$; yellowish (green when alive); frontal callosity absent; thorax and abdomen uniformly greenish yellow; wings hyaline, several crossveins with narrow brown margins; hind tibiae without spurs. Males similar to females except for sexual differences.

This species is readily separated from other species of tabanids by its uniform yellowish color in pinned specimens.

Larvae (Fig. 109) have usually been found along the edges of ponds and slow moving streams and in floating vegetation in open water (Tidwell 1973). Wilson (1969) collected larvae from the forest floor.

C. crepuscularis is a southeastern species, extending from Florida to Delaware and west to central Texas (Fig. 153). As yet this species has not been collected in Illinois although specimens have been examined from western Tennessee.

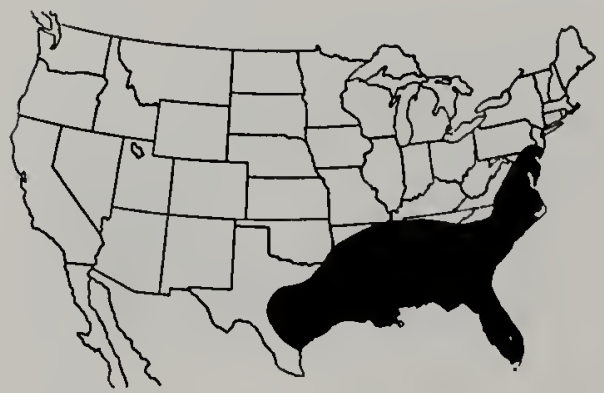

Fig. 153.-Distribution of Chlorotabanus crepuscularis in North America.

\section{Haematopota Meigen Haematopota rara Johnson}

Haematopota rara Johnson (1912:182).

Type-locality: Pennsylvania, Folsom.

Moderate size $(8 \mathrm{~mm})$; slender gray species; frons wider than high, with narrow callus across its entire width, a velvety black spot on each side directly above callus; eyes essentially bare; first antennal segment enlarged, shining: wings gray with white maculations (Fig. 76). Male with distinctly hairy eyes but easily associated with female on characters of the antennae and wing.

This species, with the white wing maculations, is not likely to be confused with any other species which may be found in Illinois.

The immature stages of this species are unknown; adults have been taken frequently in sphagnum bogs, and such situations may also be a favored larval habitat.

$H$. rara is an eastern species with several disjunct populations from eastern Tennessee to Cape Breton lsland (Fig. 154). As yet it has not been collected in Illinois although specimens have been examined from Ohio.

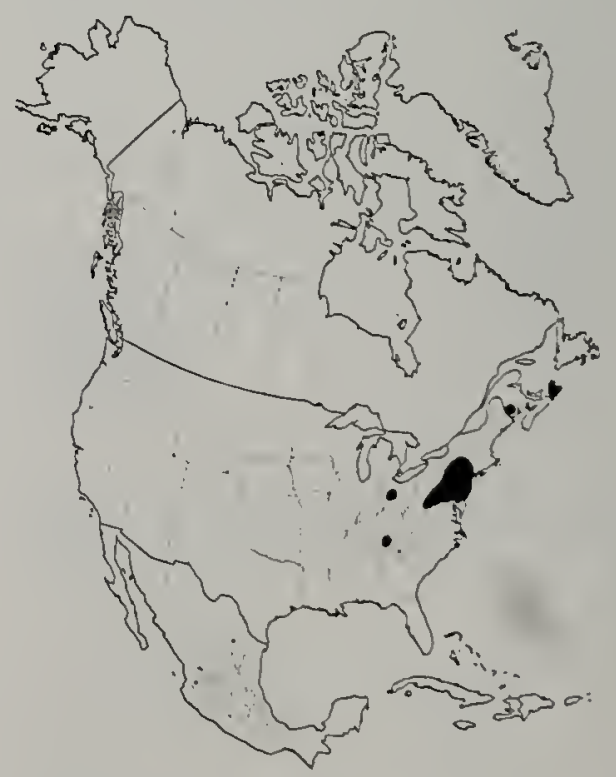

Fig. 154.-Distribution ol Haematopota rara in North America. 


\section{Atylotus Osten Sacken}

At least four species of this genus are found in Illinois. All of them are small or moderately sized hairy insects of little economic importance. Considerable variation is exhibited in Atylotus, and the determination of some specimens to the specific level is sometimes difficult.

\section{KEY TO SPECIES OF ATYLOTUS}

\section{Females}

1. Frons with 2 small rounded callosilies .....................................................woodi

Frons without callosities ............................2

2. Pleural hairs bright yellow; basal plate of antennae about as broad as long bicolor

Pleural hairs gray; basal plate variable. slender to broad..

3. Abdomen with whitish hairs; frons of moderate widıh; basal plate of antennae almost as broad as long; palpi short. thick, abruptly tapering to point: eye in life usually with diagonal band...... ohioensis

Abdomen with mostly yellow hairs: frons rather narrow; basal plate of antennae never as broad as long: palpi not especially thick or abruptly tapered; no band on eye in life.

.thoracicus

\section{Males}

1. Postocular fringe very short, not recurved forward over upper eye margins.

Postocular fringe long, recurved over eyes ...bicolor

2. Pleural hairs bright yellow

Pleural hairs gray ...

3. Abdomen with hairs mostly whitish; sometimes with median patches of black hairs and some sublateral yellowish hairs; basal plate of antennae broad; eye in life usually with diagonal band .ohioensis

Abdomen with hairs mostly yellow: basal plate of antennae rather narrow; no eye band in life

thoracicus

A key to the larval stages is incorporated within the key to the larval stages of Tabaurs.

\section{Atylotus bicolor (Wiedemann)}

Tabamus bicolor Wiedemann (1821:46). Type-locality: North America.

Tabanus fulvescens Walker (1848:171). Type-locality: Massachusetts and unknown (cotypes).

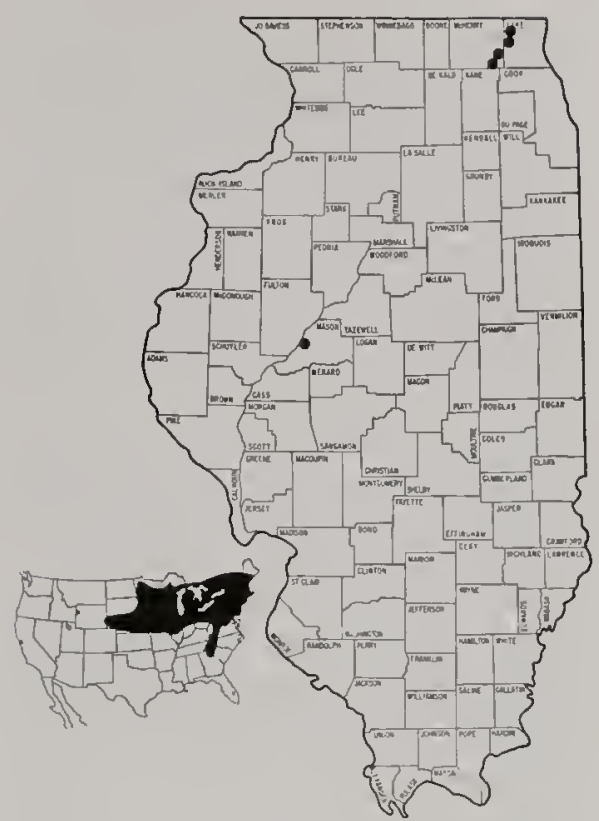

Fig. i55.-Distribution of Atylotus bicolor in Illinois and North America.

Tabanus reficeps Macquart (1855:55). Type-locality: Maryland, Battimore. Small to moderate size (1l $\mathrm{mm})$; yellow or light orange; abdomen with median, indefinitely outlined dark area; wings hyaline, costal cell hyaline or pale yellow; eyes hairy. Male eye facets differentiated; eyes hairy.

Larvae (Fig. 218) have been collected from such diverse habitats as the muddy banks of ponds and streams, sphagnum bogs, wet sod, and sod in salt marshes (Pechuman 1972; Teskey 1969).

In Illinois adults appear in early July and have been collected until late July.

A. bicolor is a northern species, extending from the District of Columbia to Maine and west to Alberta (Fig. I55). In Illinois this species has been collected in the two northeastern counties, and a single record exists from Havana, Mason Comnty (Fig. 155).

\section{Atylotus ohioensis (Hine)}

Tabanus ohioensis Hine (1901:28). New name for pruinosus Hine (1900). 
Tabanus pruinosus Hine (1900:248).

Name preoccupied (Bigot 1892).

Type-locality: Ohio.

Small size $(9 \mathrm{~mm})$; grayish black; abdomen often grayish laterally on first 2 tergites; wings hyaline, costal cell sometimes faintly tinged with yellow; eyes hairy. Male eye facets differentiated; abdomen laterally often more extensively pale than in female; eyes hairy.

Although of minor importance, $A$. ohioensis attacks man and animals. It attacks man around the head, much as do several species of Chrysops.

Larvae (Fig. 216) have been collected in saturated pasture sod, seepage areas, and moss along streams (Pechuman 1972; Teskey 1969).

In Illinois adults appear in late June and have been collected until early July.

A. ohioensis is a northern species, extending from Pennsylvania to Alberta (Fig. 156). This species has been collected at only two localities in northcentral Illinois.

Illinois Records.-Bureau County, Princeton; Woodford County. Spring Bay.

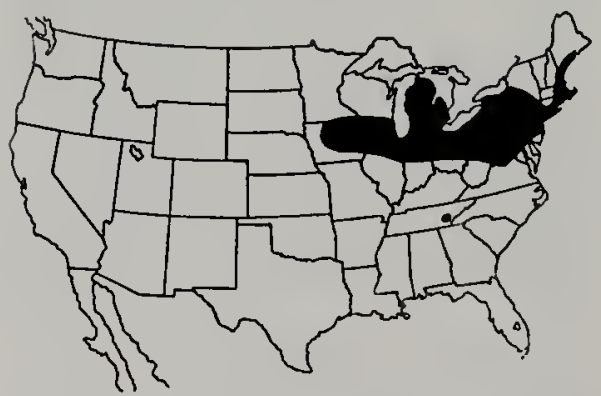

Fig. 156.-Distribution of Atylotus ohioensis in North America.

\section{Atylotus thoracicus (Hine)}

Tabamus thoracicus Hine (1900:248). Typelocality: New York, Oswego.

Small size $(10 \mathrm{~mm})$; dull yellowish; abdomen with median indefinitely outlined dark area, which is broader posteriorly; wings hyaline, costal cell pale yellow; eyes hairy. Male eye facets differentiated: eyes hairy:

Although not a common species, $A$. thoracicus is sometimes found in ratler large numbers in sphagnum bogs, and males are as commonly collected as females. The flight is weak, and when disturbed, this species rarely flies more than a few yards. There are no records of $A$. thoracicus biting.

Larvae (Fig. 215) have been found in open areas of a sphagnum bog mat (Teskey 1969).

In llinois adults appear in mid-July and have been collected until late July:

A. thoracicus is a northern species, extending from Delaware to Nova Scotia and west to Wisconsin (Fig. 157). In Illinois this species has been collected at a single locality.

Illinois Records.-Iroquois County; Iroquois County Conservation Area (3 miles NE Beaverville).

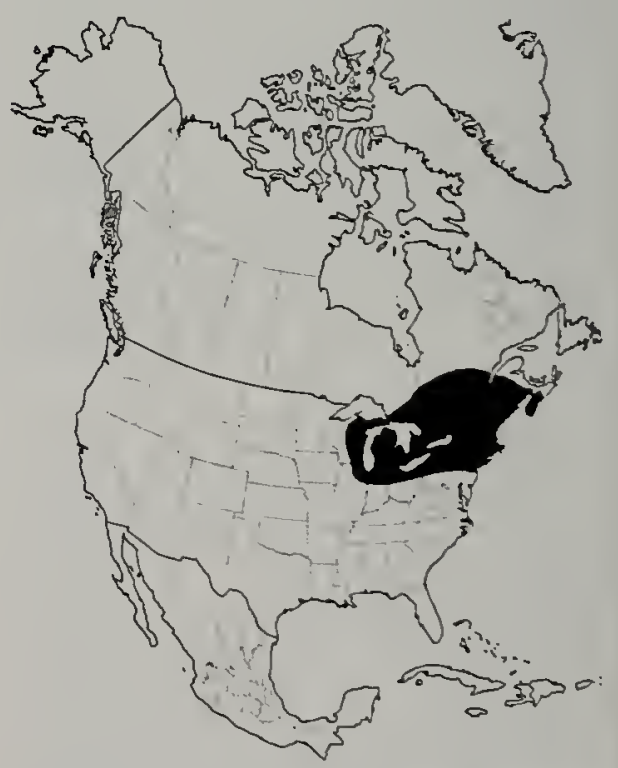

Fig. 157.-Distribution of Atylotus thoracicus in North America.

\section{Atylotus woodi Pechuman}

Atylotus atoodi Pechuman (1981:2). Typelocality: Ontario, Wellington Countr: Puslinch Township.

Moderate size $(10.5 \mathrm{~mm})$; gravish yellow: eye with fine short hairs: frons with two rounded calli well separated from each other and from frontal margins; femora and tibiae yellow; abdomen with broad dark median longitudinal stripe, yellowish laterally: Male 
easily associated with female; hairs on upper occipital margin short, not recurved over eyes.

The presence of frontal calli in the female and the short nonrecurved hairs of the upper occipital margin in the male separate this species from all other Atylotus known from Illinois.

Larvae (Fig. 217) have been found in a marl bog (Teskey 1969, species C).

In Illinois adults have been collected only once, which was in early August.

$A$. woodi is a northern species, extending from Ontario to northern Illinois and southern Wisconsin (Fig. 158). This species has been collected at only a single locality in northeastern Illinois.

Illinois Records.-Lake County, Cedar Lake.

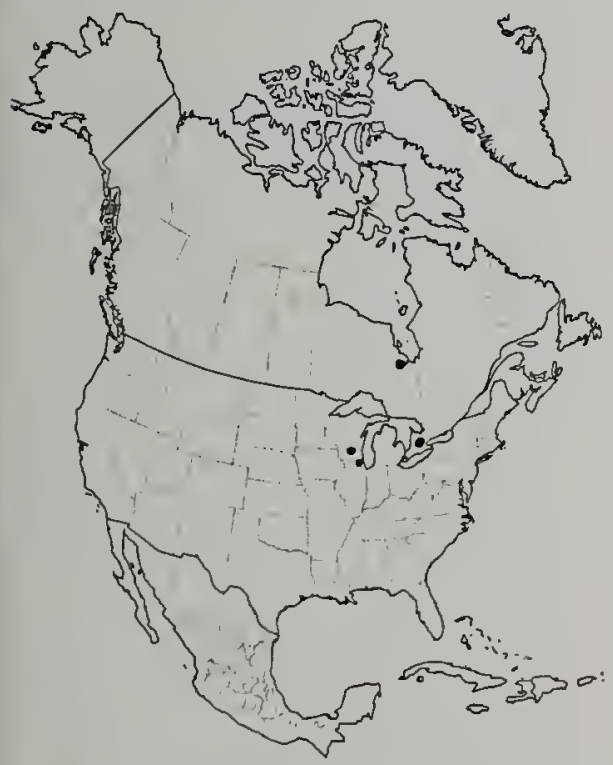

Fig. 158.-Distribution of Atylotus woodl in North America.

\section{Leucotabanus Lutz} Leucotabanus annulatus (Say)

Tabanus annulatus Say (1823:32). Typelocality: Missouri

Moderate size $(11 \mathrm{~mm})$; frons very narrow; small basal callus continued dorsally as slender line; ocellar tubercle present; abdomen brownish with pale bands. Male superfically quite dif- ferent from female; thorax and abdomen with long white hairs; upper eye facets enlarged, distinctly divided from smaller lower facets.

This species is crepuscular and probably nocturnal. On occasion it will attack cattle in numbers at dusk.

The larvae (Fig. 112) are found in rot holes in trees, in decaying logs, and less commonly in soil beneath forest litter (Tidwell 1973).

In Illinois adults appear in early July and have been collected until midAugust.

L. annulatus is a southeastern and central species, extending from southern Florida to Delaware and west to Kansas and eastern Texas (Fig. 159). In Illinois this species is collected only in the southern third of the state (Fig. 159).

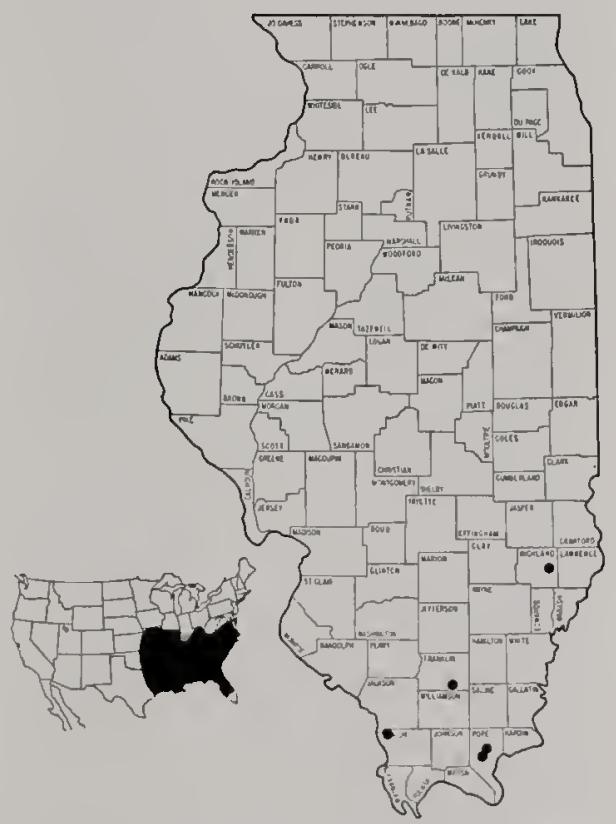

Fig. 159.-Distribution of Leucotabanus annulatus in Illinois and North America.

\section{Tabanus Linnaeus}

The present restriction of the genus Tabamus is discussed under the genus Hybomitra.

Tabanus includes some of the largest flies in Illinois although some species are quite small. Some major pests of man, livestock, and wildlite are in this genus. Serious pests of livestock in- 
clude T. atratus, equalis, quinquevittatus, similis, and sulcifrons. Species that frequently attack man are T. lineola, pumilus, and both subspecies of sparus. Along with the species of Hybomitra, species of Tabanus are commonly called "horse flies"; the bright green color of the eyes of some species accounts for the use of the name "greenhead" in some areas.

\section{KEY TO SPECIES OF TABANUS}

\section{Females}

1. Eyes hairy (if hair inconspicuous, palpi very slender, frons narrow, abdomen with pale median line, round sublateral spots) ……………………………....2

Eyes bare .......................................................4

2. Larger species (13-15 mm); palpi very stout at base, tapering to acute point: frontal callus does not touch eyes.....

orbicallus

Smaller species $(10-13 \mathrm{~mm})$; palpi very slender, only slightly enlarged at base; frontal callus touches eyes

3. Frons about 2.5 times as high as wide: basal callus wider than high; base of third antennal segment rather slender ..........................................quaesitus

Frons about 4 times as high as wide; basal callus square or higher than wide: base of third antennal segment rather broad ...........................exilipalpis

4. Abdomen unicolorous or with narrow, indistince posterior bands

Abdomen with one or more median triangles (Fig. 170) or median stripe (Fig. 164-168)

5. Subcallus denuded .................atratus atratus

Subcallus pollinose...........................................

6. Bifurcation with distinct spot, or entire wing dark

Bifurcation without distinct spot, wing essentially hyaline

7. Palpi pale to reddish brown ..........gladiator Palpi dark brown to black ............................8

8. Mesonotum white pollinose............................9

Mesonotum dark brown .............................10

9. Frons orange brown, moderate width: wing veins not margined with brown although darker clouds may be present....................................................stygius

Frons gray, broad; wing veins margined with brown subniger

10. Frons narrow, widened above; antennae mostly orange including first $2 \mathrm{seg}-$ ments. proximus

Frons wide, parallel sided; first 2 antennal segments black, third often partly black nigrescens

11. Wing hyaline with dark brown costal cell: abdomen usually with narrow gray posterior border .............americanus

Wing uniformly dilutely infuscated; costal cell yellow; abdomen (Fig. 160) sometimes with traces of small median triangles . calens (in part)

12. Abdomen orange brown with median dark area; wing spotted; femora black. abdominalis

Abdomen with pale median stripe (Fig. $164-168$ ) or spots (Fig. 174-176) .......13

13. Abdomen with longitudinal abdominal stripe (Fig. 164-168), which may or may not be widened at posterior margins of segments

Abdomen with median markings not forming uninterrupted stripe .25

14. Spots forming median abdominal stripe nearly parallel sided (Fig. 161, 164. 165); lateral markings usually form shorter stripe on each side of median stripe and parallel to it, this stripe may be broken into separate spots or may be obsolete

Spots forming median abdominal stripe widened at posterior margins of segments (Fig. 166-168), lateral markings broken into separate, often roundish spots

15. Prescutal lobe usually paler than mesonotum; frons widened above; annulate portion of third antennal segment usually shorter than basal plate; costal cell usually hyaline; eyes in life with? purple bands.

Prescutal lobe concolorous with mesonotum: frons nearly parallel sided: annulate portion of third antennal seg. ment usually longer than basal plate; costal cell infuscated; eyes in life with single purple band

16. Scutellum and mesonotum dark gray to black concolorous; frons 4.5 to 5.0 times as high as wide.........lineola lineola

Scutellum reddish, sometimes faincly; on posterior margin: frons rarely more than 3.5 times as high as wide..............17

17. Legs predominantly reddish; sublateral abdominal stripes essentially parallel sided (Fig. 162) ..................................similis

Femora of at least fore and hind legs darkened; sublateral abdominal stripes offset between second and third segments (Fig. 163) ....subsimilis subsimilis

18. Vellowish species: palpi. pleurae, and face yellow quinquevittatus

Blackish species; palpi and face white: pleurae grayislı ..............................mularis

19. Dorsum of thorax covered with yellow hairs, without longitudinal stripes: abdominal stripes vellow; frons vers narrow: antennal plate broad; costal cell coloted ..............................................20

Without this combination of characters....21

20. Annulate portion of third antennal segment black: femora dark, palpi sel- 
low; face and pleurae yellow haired fulvulus

Third antennal segment usually entirely orange yellow; femora pale, someimes darkened at base; palpi white; face and pleurae pale baired

pallidescens

21. Frons very narrow, at least 5 times as high as width at base ........................22

Frons not over 4.5 times as high as wide, usually broader

22. Frons widened above: basal plate of antennae very narrow, over (wice as long as greatest width.. ..sackeni

Frons essentially parallel sided; basal plate of antennae broad, never more than one and one half times as long as greatest width .................................. wilsoni

23. Second palpal segment much swollen basally"; median abdominal stripe broad ...sagax

Second palpal segment not very swollen basally: median abdominal stripe narrow

24. Pale markings of abdomen yellowish brown, sublateral spots touch hind margins of segments (Fig. 169); frons over 3.5 times as high as wide.

sublongus

Pale markings of abdoman grayish, sublateral spots small, separated from hind margins; frons not more than 3.5 times as high as wide longus

25(13). Second abdominal segment with no pale median spot but occasionally two small sublateral spots (Fig. 170); fore tibiae distinctly bicolored; thorax white pollinose.......................trimaculatus

Second abdominal segment with pale median spot (Fig. 171, 174) .

26. Abdomen with both median and sublateral spots (Fig. 171-177) .................27

Abdomen without sublateral spots although abdomen may be paler laterally .

35

27. Wings with large brown spots not confined to crossveins and bifurcation; sublateral pale spots of abdomen usually confined to tergites $4-6$ (Fig. 171) ................................................venustus

Spots on wings, if present, confined to crossveins and-bifurcation: sublateral pale spots usually on tergite 2 (Fig. $174-176$ )

28. Bifurcation with dark spot; grayish species.

Bifurcation without dark spot; coloration variable

29. Median and sublateral spots broadly joined along posterior margins of abdominal segments (Fig. 172); frons

\footnotetext{
'Some specimens of orbucallus with inconspicuous hatrs on the eye will key to this perint; such specimens mav be distinguished frum sagax by the narrow, almost obsolete, pale median abdominal triangles and the frons, which is distinctly widened above,
}

narrow; basal callus higher than wide..................................cymatophorus

Median and sublateral spots narrowly or not at all joined along posterior margius of abdominal segnents (Fig. 173); frous broad, basal callus almost square ..................................... reinwardtii

30. Small species, usually $12 \mathrm{~mm}$ or less; frons widened above; costal cell hyaline ....................................................31

Large species, usually $13 \mathrm{~mm}$ or more, differing in at leasi one other character from above

31. Median callus large; palpi not swollen basally or sharply pointed; eyes in life with 2 purple bands......................pumilus

Median callus slender; palpi swollen basally but with apex acute; eyes in life unicolorous or with single purple band

32

32. Eyes unicolorous in life ........sparus sparus Eyes with single purple band .... sparus milleri

33. First antennal segment swollen above: sides of subcallus usually with few hairs..

fairchildi

First antennal segment not swollen above; sides of subcallus without hairs .......................................................... 3

34. Sublateral white abdominal spots considerably larger than small median triangles, usually reaching anterior border of second and third segments (Fig. 177) ..............................marginalis

Median abdominal triangles relatively larger, sublateral spots smaller, rarely extending to anterior border of segments

35(26). Second abdominal segment with pale spot distinctly smaller than spots on third and fourth segments (Fig. 178, 179): scutellum with pale pile; fore tibiae unicolorous ...........................36

Second abdominal segment with pale spot not markedly smaller than those on segments 3 and 4 (Fig. 184-186).......38

36. Abdomen black with very small median triangles (Fig. 178) ......superjumentarius

Abdomen usually brownish, at least in part; median triangles large (Fig. 179) ......................................................37

37. Genae, pleurac, venter pale haired .......

Genae, pleurae, venter brown haired... molestus mixis

38. Bifurcation witl no spot .........................39

Bifurcation witl conspicuous spot ..........43

39. Wings with smoky tinge; costal cell dark yellow: abdomen with median triangles small or obsolete (Fig. 160. 180); large species, 19-25 num ...........40

Wings hyaline; costal cell hyaline or sliglitly tinted; abdomen witb median triangles conspicuous (Fig. 181); snatler

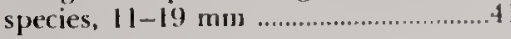




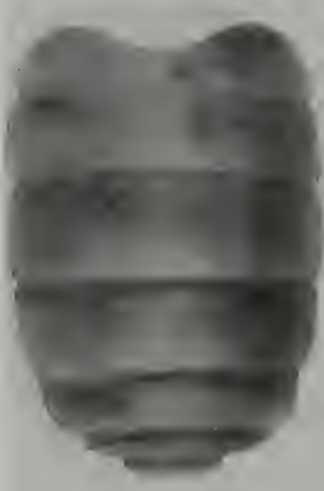

160

catens

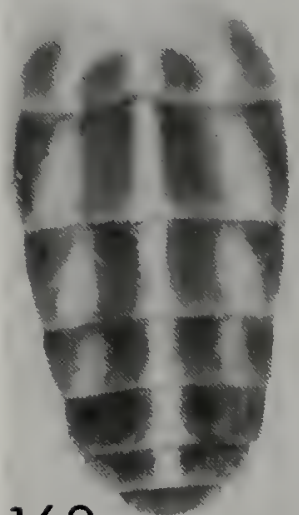

163

Qubsimilis

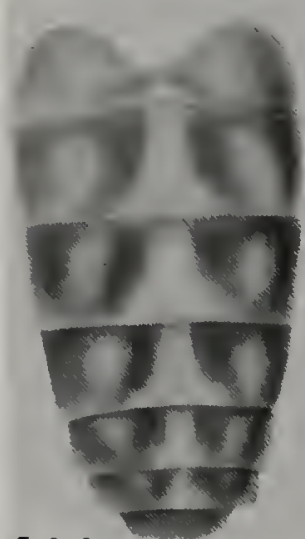

166

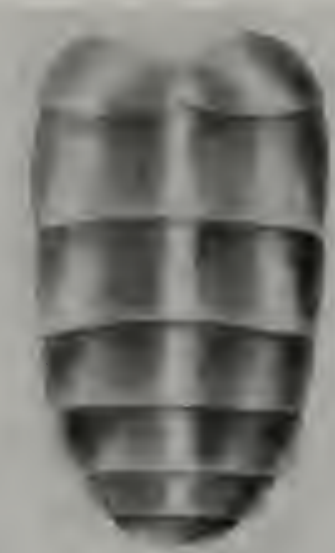

161

$\operatorname{lin} \theta 010$

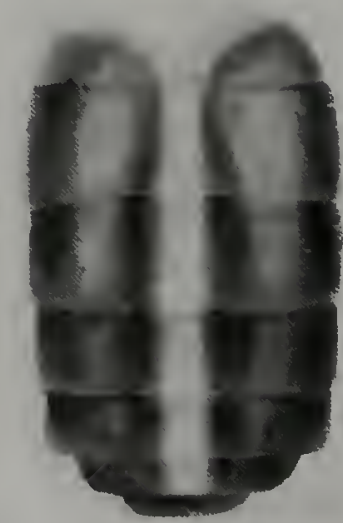

164

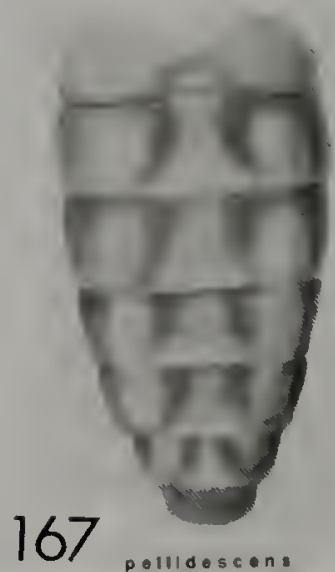

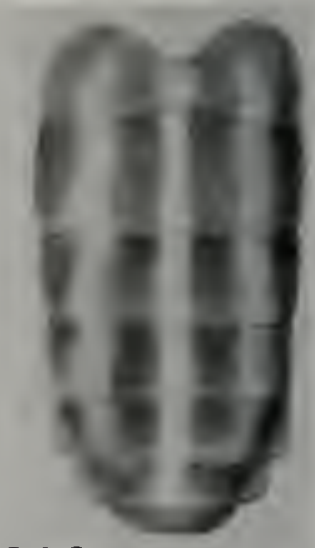

162

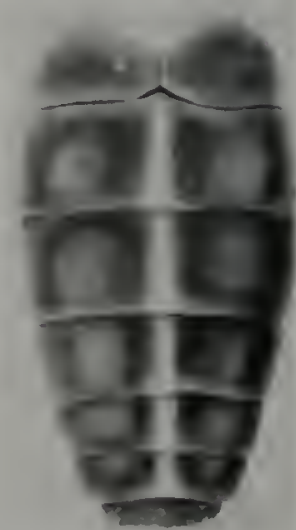

165 mularis

Fig. 160-168.-Abdominal patterns. 160. Tabanus caiens. 161. T. lineola. 162. T. similis. 163. T. subsimlils. 164. T. quinquevittatus. 165 . T. mularis. 166 . T. fulvulus. 167 . T. paliidescens. 168. T. sackeni. 


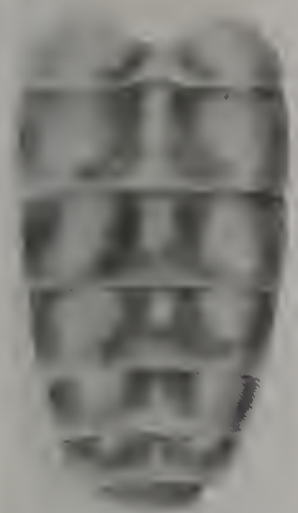

169

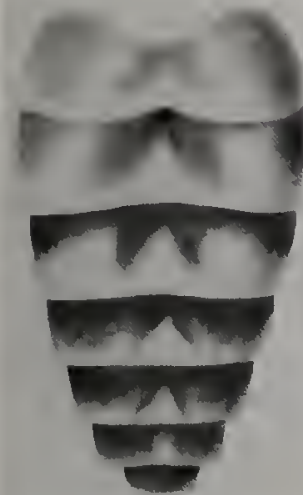

172

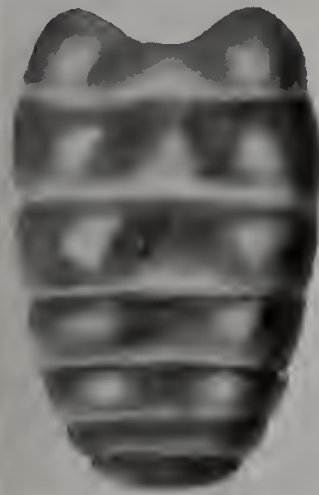

175

Fig. 169-177. Abdominal patterns. 169. Tabanus subiongus. 170. T. trimacuiatus. 171. T. venustus. 172. T. cymatophorus. 173 . T. reinwardtil. 174 . T. pumlilus. 175 . T. sparus sparus 176. T. falrchlidi. 177. T. marginalis.

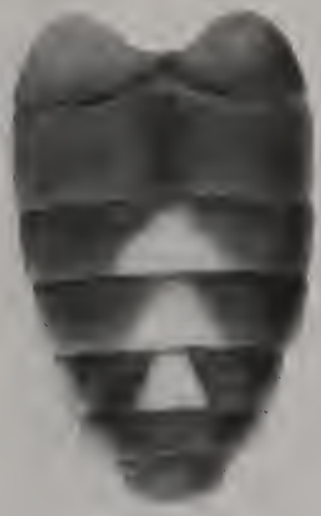

170 Inmacuratus

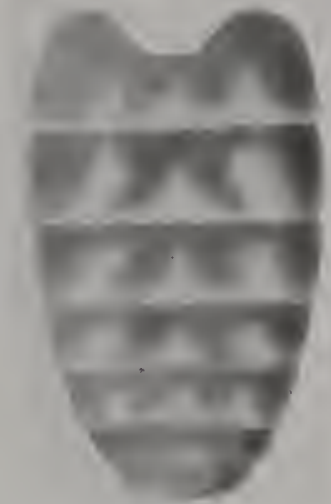

173

174
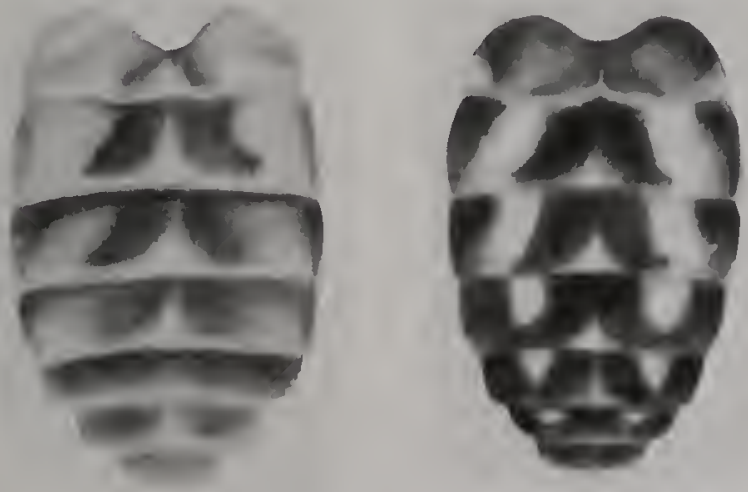

177 moroinalie

alichiol

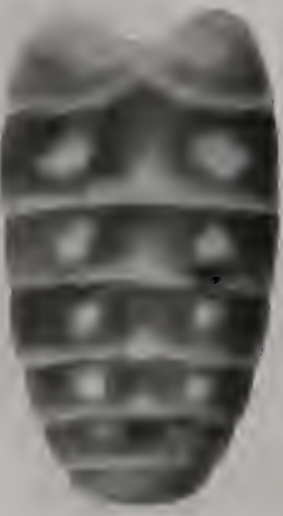

umillus 


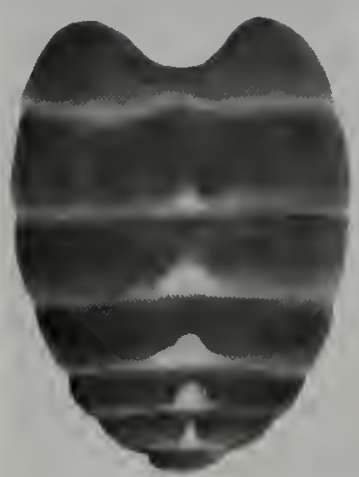

178

superjumentarius

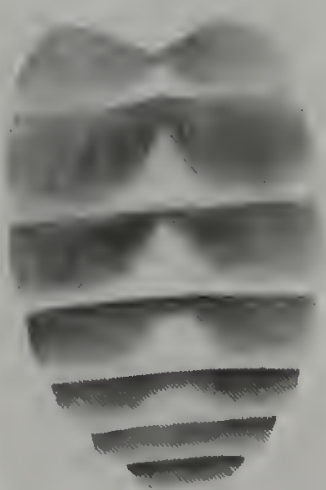

181

nigripes

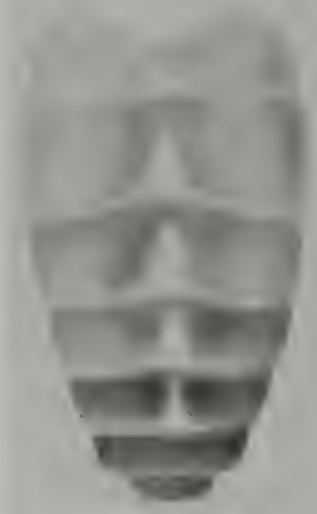

184

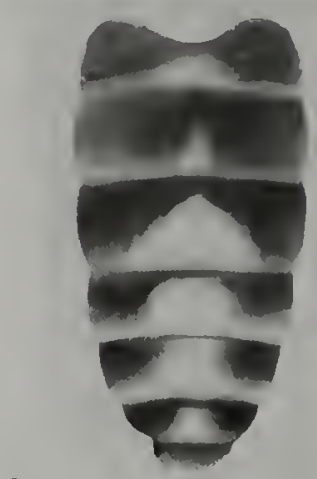

179

molestus

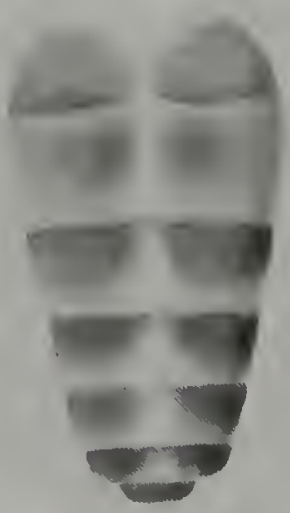

182

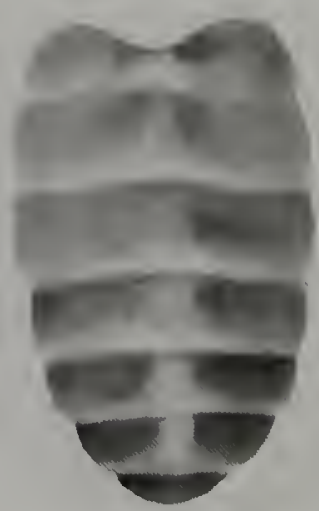

185

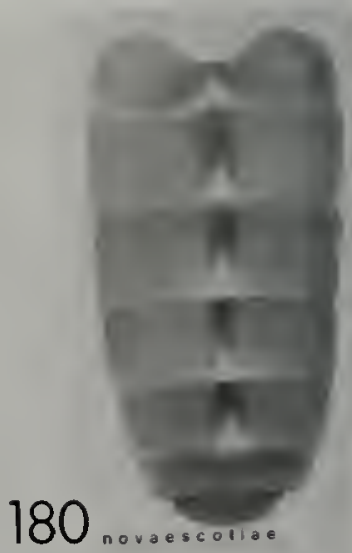

Fig. 178-186.-Abdominal patterns. 178. Tabanus superjumentarlus. 179. T. molestus. 180. T. novaescotiae. 181 . T. nigripes. 182 . T. petiolatus. 183 . T. melanocerus. 184 . T. sulcifrons. 185. T. turbidus. 186. T. equalis. 
40. Fore tibiae unicolorous; median abdominal triangles obsolete, arising from faint posterior bands (Fig. 160) calens (in part)

Fore tibiae bicolored; abdominal triangles small but distinct, not arising from bands (Fig. 180) novaescotiae

41. Tibiae unicolorous, fore tibiae may be slightly paler at base; first posterior cell slightly or not at all narrowed at margin; subcallus thinly pollinose or denuded; usually under $15 \mathrm{~mm}$ nigripes

At least fore tibiac bicolored; first posterior cell much narrowed, closed at margin or petiolate; subcallus pollinose; larger species, $15-19 \mathrm{~mm}$...

42. Frons over 6 times as high as width at base; hind tibiae uniformly yellowish white, barely darkened at apex; second abdoninal segment with median triangle usually crossing segment, joining spot on first segment (Fig. 182); first posterior cell usually closed, frequently petiolate. petiolatus

Frons less than 6 times as high as wide; hind tibiae often extensively dark toward apex; second abdominal segment with median iriangle rarely crossing segment (Fig. 183); first posterior cell may be open or closed, rarely petiolate. melanocerus

$43(38)$. Fore tibiae bicolored, basally pale with pale hair ....44

Fore tibiae unicolorous, occasionally base somewhat brownish with orange hair 45

44. Frons narrow (Fig. 189), 5 times or more as high as wide; first posterior cell normally petiolate, sometimes closed at margin ................. limbatinevris

Frons moderately wide (Fig. 187), averaging 4.5 times as high as wide; first posterior cell normally open although often narrowed at margin........sulcifrons

45. Costal cell yellow; frons 6 times as high as width at base, distinctly widened above; antennae usually wholly orange turbidus

Costal cell hyaline or faintly tinted; frons about 4.5 times as high as wide, scarcely widened above; basal plate of third antennal segment partly black equalis

\section{Males ${ }^{1}$}

1. Eyes hairy 2

Eyes bare

2. Upper eye facets considerably enlarged, occupying about three-fourths of total eye area; abdomen with parallel-sided median longitudinal stripe and similar more ir regular sublateral stripes subsimilis subsimilis

Eye facets all of one size or upper facets slightly enlarged; abdomen otherwise marked .3

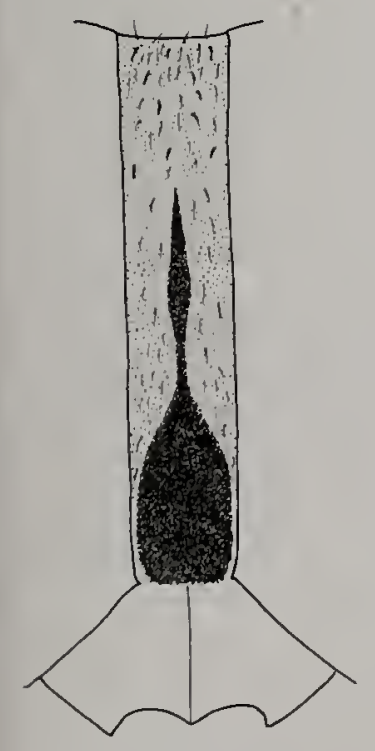

187

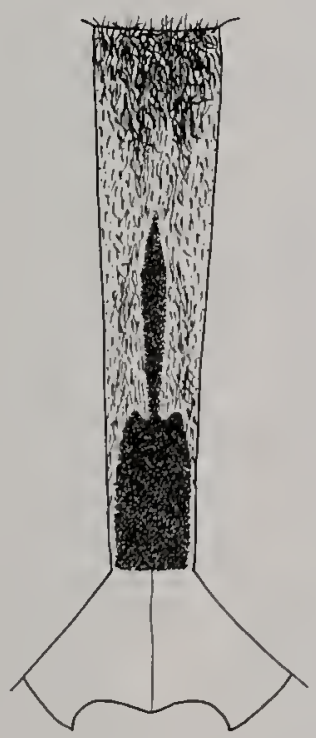

188

IThe male has not been recognized for Tabanus longus.

Fig. 187-189.-Frontes. 187. Tabanus sulclfrons. 188. T. abdominalis. 189. T. limbatinevrls. 
3. Bifurcation and crossveins of wing with distinct brown spots reinwardtii

No spots on wings.

4. All femora black; first antennal segment swollen above; hair on eyes sparse ....

fairchildi (in part)

Femora brown, sometimes with dusky shadows; first antennal segment not swollen; hair on eyes abundant . .5

5. Dorsal margin of occiput and vertex with dense fringe of white hair: palpi large and stout, less than twice as long as greatest thickness; pale median markings of abdomen obsolete ........... orbicallus

Dorsal margin of occiput and vertex with fringe of long dark hairs, recurved forward: palpi either very small or about 2.5 times as long as greatest thickness; pale median markings of abdomen distinct

6. Basal plate of antennae rather slender, about 2 times as long as greatest width ........................................quaesitus

Basal plate broader, about 1.5 times as long as wide. exilipalpis

7 (1). Abdomen unicolorous or with narrow indistinct pollinose bands..

Abdomen with median markings .............14

8. Frontal triangle denuded and shining; third antennal segment with rather long tooth; black species with heavily infuscated wings ................atratus atratus

Frontal triangle pollinose, differs in at least one other character from the above.

9. Bifurcation without distinct spot ..............10

Bifurcation with distinct spot or wing mostly black

10. Wing dilutely infuscated, costal cell darker, hind tibial fringe black calens (in part)

Wing hyaline. costal cell deep yellow; hind tibial fringe orange ......americanus

11. Genae gray.. proximus

Genae brown to black .12

12. Lower margin of area of large facets of eye somewhat sinuate, at lowest point about on level with top of antennal pits subniger

Lower margin of large facets more nearly straight, somewhat higher than antennal pits

13. Integument of thoracic dorsum brown, contrasting with black abdomen; wing membrane, except for spots, rather uniformly dilutely infuscated........stygius

Integument of thoracic dorsum dark brown to black, usually contrasting but slightly with black abdomen; apex of wing, except for spots, almost hyaline nigrescens
14(7). Abdomen broadly orange laterally with conspicuous black median spots; pale median spots absent or obsolete; large and small eye facets little differentiated; femora black; wings spotted, first posterior cell often narrowed at wing margin ...........................15

Abdomen with pale median markings; differs in at least one other character from the above.

15. Thorax with lavender tint, narrowly and inconspicuously striped; second palpal segment slender, 3 imes as long as thick; all tibiae essentially unicolorous.................................................. gladiator

Thorax brown, broadly and conspicuously striped: second palpal segment about twice as long as thick: all tibiae distinctly paler at base ..........abdominalis

16. Abdomen with longitudinal stripe which may or may not be somewhat widened at posterior margins of segments .........17

Abdomen with median markings that do not form uninterrupted stripe ........26

17. Spots forming median abdominal stripe parallel sided; sublateral spots similar but often more irregular, rarely broken into roundish spots.

Median spots widened at posterior margin of each segment so that stripe not parallel sided; sublateral spots usually roundish

18. Prescutal lobe usually paler than mesonotum: annulate portion of third antennal segment usually shorter than basal plate; costal cell usually hỵa-

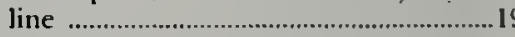

Prescutal lobe usually concolorous with mesonotum; annulate portion of third antennal segment as long as or longer than basal plate; costal cell infuscated

19. Scutellum and thorax dark gray to black, concolorous; hind femora usually dark. ..lineola

Scutellum reddish, sometimes faintly; on posterior margin; hind femora usuall! reddish (if scutellum partly reddish. upper eye facets enlarged, and femora dark, see subsimilis, couplet 2.) ......similis

20. Palpi and pleurae yellow pollinose ....... quinquevittatus

Palpi, face, and pleurae white or gray pollinose ...........................................mularis

21. Upper eye facets not much larger than lower facets ................................................22

Upper eye facets much larger than lower facets.

22. Hair and pollen of face, mesonotum. and pleurae yellow......................... fulvulus

Pollen of face and pleurae gray, hairs gray to pale yellow; hairs of mesono- 
tum mixed gray and black.

wilsoni

23. Third antennal segment entirely orange; long hairs on dorsum of thorax yellow pallidescens

Third antennal segment with at least annuli dark; long hairs on dorsum of thorax black to gray

24. Costal cell hyaline; short recumbent hairs of thoracic dorsum gray: sublateral abdominal spots gray ........sackeni

Costal cell tinted; short hairs of thorax often yellowish; sublateral abdominal spots usually yellow or with yellowish int

25. Median abdominal stripe broad: face below eyes with many black hairs, beard yellowish white; second palpal segment stout, yellow brown with many black hairs sagax

Median abdominal stripe narrow; face with almost no black hairs, beard pale gray; second palpal segment relatively slender, pale yellowish white with few black hairs sublongus

26(16). Frontal triangle bare, somewhat protuberant; abdominal triangles sometimes indistinct; small chunky species usually under $13 \mathrm{~mm}$....nigripes

Frontal triangle pollinose.. . .27

27. Abdomen with median spots or triangles, at least some segments with sublateral spots

Abdomen with median spots or triangles; no distinct sublateral spots although some segments may be paler laterally

28. First antennal segment swollen above; third antennal segment entirely black; eyes sometimes with sparse hairs..

fairchildi (in part)

First antennal segment not swollen; third antennal segment variable; eyes bare....29

29. Wing with distinct spots on bifurcation, crossveins or with irregular maculations

Wing without spots although very faint spot may be present on bifurcation ....31

30. Wing with brown maculations not confined to bifurcation and crossveins; white bands of tergites 2-4 nearly obliterate median and sublateral spots but spots distinct on tergite 5 ......venustus

Wing spots confined to bifurcation and crossveins; abdomen otherwise marked .cymatophorus

31. Fore tibiae entirely black; sublateral abdominal spots very large, often crossing second and third segments; third antennal segment black ..........marginalis

Fore tibiae paler at base; sublateral spots smaller; third antennal segment rarely entirely black
32. Moderate-sized species, 14-15 mm: second palpal segment yellow brown, about twice as long as wide; median triangles fairly large, sometimes crossing segment; sublateral spots reach posterior margin on at least second segment; anterior portion of wing somewhat tinted ...............................vivax

Small species, usually under $11 \mathrm{~mm}$; second palpal segment whitish, less than twice as long as thick; median triangles small, never crossing segment; sublateral spots small, rarely reaching posterior margins of segments; wing entirely hyaline

33. Tibize same color as reddish brown to brown femora or slightly paler basally; antennae yellowish, of en with annulate portion somewhat darker; basal plate 2.5 to 3 times as long as wide: occipital tubercle prominent, often projecting above level of eyes ....pumilus

Tibiae distinctly paler than dark femora except apex of fore (ibia, which is dark; antennae uniformly dull brownish; basal plate about twice as long as wide; occipital tubercle inconspicuous. compressed, usually not reaching level of eyes

34. Eye in life without stripes ....sparus sparus Eye in life with single purple stripe ...... ...sparus milleri

35(27). Pale spot on second abdominal segment much smaller than those on third and fourth segments, or absent...36

Pale spot on second abdominal segment not markedly smaller than those on two following segments

36. Abdomen blackish with large white triangles not arising from bands on tergites 3-5; fore tibiae bicolored ...trimaculatus

Without this combination of characters....37

37. Abdominal triangles very small, not arising from bands; scutellum concolorous with thorax; area of large eye facets occupies about half of total cye area, sharply demarcated......superjumentarius

Abdominal triangles moderate in size, often arising from bands; scutellum white pollinose, contrasting with dark thorax; area of large facets occupies about two-thirds of total area, not sharply demarcated...

38. Face and cheeks gray pollinose; abdominal spots arise from pale bands. which may cover posterior half of third and fourth segments; venter with wide gray bands

molestus molestus

Face and cheeks mostly brown pollinosc: abdominal bands, if present, very narrow on dorsum and venter molestus mixis 
39. No spot at bifurcation

Bifurcation with conspicuous spot ..........43

40. Little differentiation in size of eye facets, line of demarcation indistinct; large species (over $20 \mathrm{~mm}$ ) with very small median triangles, dark yellow legs and antennae .............................calens (in part)

Large eye facets distinctly set off from small facets; size not over $20 \mathrm{~mm}$, usually less; third antennal segment at least partly dark.

41. Larger species $(20 \mathrm{~mm})$; abdomen with median black stripe on which pale median triangles superimposed; femora chestnut brown ..............novaescotiae

Smallerspecies ( $16-17 \mathrm{~mm})$; pale median abdominal triangles not on black stripe; femora dark brown to black ....42

42. Median triangle crosses second abdominal segment; hind tibiae usually completely pale; large facets occupy about half of eye area petiolatus

Median triangle does not cross second abdominal segment; hind tibiae darkened at apex; large eye facets occupy about two-thirds of total eye area..... melanocerus

43. Legs rather uniformly yellowish to dark brown, fore tibiae not paler at base ...44

Legs with femora darker than tibiae. fore tibiae paler at base. . .45

44. Third antennal segment usually wholly yellow; costal cell yellow, veins outlined in brown; upper eye facets much enlarged turbidus

Third antennal segment partly black; costal cell hyaline or pale yellow, veins not at all or only vaguely outlined; upper eye facets only moderately enlarged........

45. Lower margin of upper eye facets straight or curved upward; first antennal segment yellow to brown; inner surface of hind tibia usually with many yellow hairs; first posterior cell clearly narrowed at wing margin....limbatinevris

Lower margin of upper eye facets usually curved downward, giving sinuate appearance or, if straight or curved upward, first antennal segment dark; inner surface of hind tibia mostly dark haired; first posterior cell rarely much narrowed at wing margin ........sulcifrons

\section{Key to Larvae of Tabanus and Atylotus}

1. Pubescence covers entire body surface (Fig. 190); mature larvae approximately $50 \mathrm{~mm}$ long.... ...americanus

Pubescence does not completely cover body, restricted to anterior or posterior margins or bordering prolegs on one or nore segments, sometimes almost absent

2. Respiratory spine present (Fig. 199-202).....3
Respiratory spine absent

3. Prothoracic annulus with single broad caudal projection laterally as if area between usual paired projections were filled with pubescence (Fig. 199, 200)...4

Prothoracic annulus with 2 narrow cau* dal projections laterally (Fig. 201, 202)..5

4. Posterior pubescence present on all abdominal segments as well as metathorax; lateral club-shaped pubescent extension of posterior annulus on anal segment connected to pubescence on anal ridges (Fig. 199)......................stygius

Posterior pubescence present on no more than last 4 or 5 abdominal segments: lateral club-shaped pubescent extension of posterior annulus on anal segment separated from pubescence on anal ridges (Fig. 200) ................ proximus

5. Posterior pubescent annulus on preanal segment with 4 rather long anterior projections laterally, dorsolateral projection connected to, or almost to, adjacent pubescent annulus bordering proleg; proleg pubescence extensive. extending between dorsal, lateral, and ventrolateral prolegs (Fig. 201)

Dorsolateral projection anteriorly from posterior pubescent annulus or preanal segment well separated from adjacent proleg pubescence; proleg pubescence narrowly borders only prolegs. does not extend between dorsal, latera), and ventrolateral prolegs (Fig. 202) ...........................................nigrescens

6. Respiratory siphon about 4 times as long as its basal diameter: third antennal segment as long as second; posterior pubescence on anal segment forms dorsal patch, does not encircle segment (Fig. 191) pumilus

Respiratory siphon no more than about twice as long as its basal diameter; third antennal segment shorter than second; posterior pubescence on anal segment, if present, not restricted 10 dorsal surface

7. Prolegs relatively long, with strong apical crochets (Fig. 192): larvae live in fastflowing streams fairchildi

Prolegs lacking crochets .............................

8. Puhescence absent from first 7 abdominal segments, apart from normal proleg spination: respiratorv siphon approximately twice as long as its basal diameter (Fig. 193-195)

Pubescence present at least anteriorly on one or more of first 7 abdominal segments or, if pubescence faint and not easily seen, respiratory siphon less than twice as long as its basal diameter

9. Pubescent markings usually restricted to small spot on each median lateral sur- 
face of anal segment (Fig. 193), occasionally indistinct patches present on posterior margin of this segment and anterior tnargin of meso and metathorax. marginalis, vivax

Pubescence either absent or differently distributed on midlateral surface of anal segment, broadly encircling posterior margin of anal segment and sometimes present on lateral anterior margin of meso or metathorax or both...

10. Pubescent markings on midlateral surface of anal segment either in form of curved band extending between anal ridge pubescence and posterior annulus or as several small patches tracing such a route (Fig. 194)....

Midlateral surface of anal segment without pubescent markings (Fig. 195) ....

nigripes

11. Very closely spaced striations present only laterally on all abdoninal segments petiolatus

Striations absent from all aspects of first 7 abdominal segments (Fig. 19.1).

melanocerus

12. Midlateral surface of anal segment with at most 1 minute pubescent spot, often bare; respiratory siphon shorter than its basal diameter; anterior pubescence encircles none of abdominal segments (Fig. 196-198).

Midlateral surface of anal segment with pubescent markings more extensive; respiratory siphon usually longer, but if short, anterior pubescence encircles first abdominal segment and usually more segments

13. Narrow pubescent annulus encircles posterior margin of preanal segment; anterior margins of first 7 abdominal segments with progressively smaller areas of pubescence (Fig. 196, 197) ..............14

Posterior pubescence absent from preanal segment; anterior pubescence on abdominal segments restricted to no more than first 2 segments (Fig. 198) ...sackeni

14. Anterior pubescent annuli on pro- and mesothorax with caudal projections laterally extending two-thirds and one-half length of segments, respectively, (Fig. 197)

molestus

Anterior pubescent annuli on pro- and mesothorax lacking or with very short caudal projections (Fig. 196)..

...fulvulus, pallidescens, wilsoni

15. All segments ornately marked with dark pubescence; anterior pubescence on meso- and metathorax and proleg pubescence on abdominal segments united laterally with posterior pubescence on same segment by $1-4$ pairs of narrow pubescent bands; pubescent annuli border prolegs with short caudal projections middorsally (Fig. 203) .......atratus

Pattern and color of pubescence variable, but anterior and proleg pubescence not connected to posterior pubescence on same segment, no distinct caudal projections of proleg pubescence dorsally

16. Prothoracic annulus with single broad caudal projection laterally, as if area between usual paired projections were filled with pubescence (Fig. 204-208).....17

Prothoracic pubescent annulus with 2 caudal projections laterally (Fig. 209218)

17. Anal segment and respiratory siphon each longer than its basal diameter

Anal segment and respiratory siphon each about equal in length to its basal diameter ....................................................20

18. Posterior pubescence present only on anal and preanal segments and encircles these segments (Fig. 204) superjumentarius

Posterior pubescence encircles all abdominal segments

19. Anal segment dorsolaterally with 4 patches of pubescence arranged in shape of reclining Y (Fig. 205)

Anal segment with only 2 patches of pubescence dorsolaterally (Fig. 206) trimaculatus

20. Body creany white; posterior pubescence encircles at least posterior $5 \mathrm{seg}$ ments; midlateral surface of anal segment with dorsal extension of anal ridge pubescence curving posteriorly, almost reaching posterior pubescent anmulus (Fig. 207) ...............novaescotiae

Body light brown to beige; posterior pubescence encircles no more than posterior 4 segments; dorsal extension of anal ridge pubescence with short apical nipple directed toward but widely separated from posterior annulus (Fig. 208) ......................................... lineola

21. Pubescence laterally on anal segment comprising narrow dorsal extension of anal ridge pubescence with 2 caudal projections from it midlaterally and dorsolaterally and with no isolated pubescent spots (Fig. 213-216); tength of respiratory siphon equal to or shorter than its basal diameter; striations usually complete on dorsal and ventral surfaces of abdominal segments ..............22

Pubescence, if present laterally on anal segment, does not form such a figure, usually with isolated pubescent spots; respiratory siphon usually longer than its basal diameter; striations usually incomplete on dorsal and ventral aspects of abdominal segments ..............26 

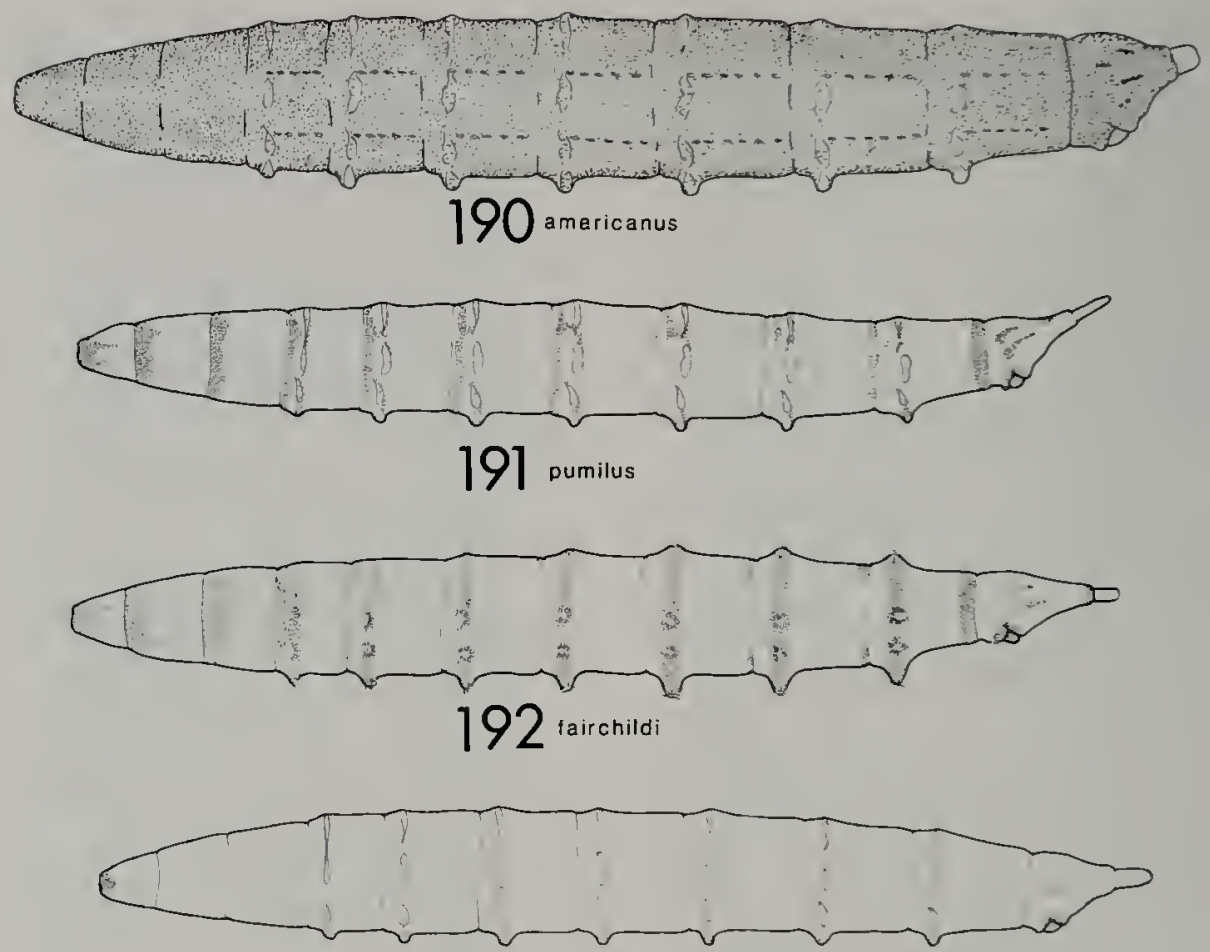

193 marginalis

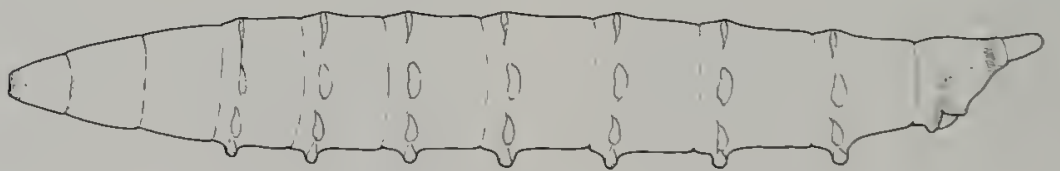

194 melanocerus

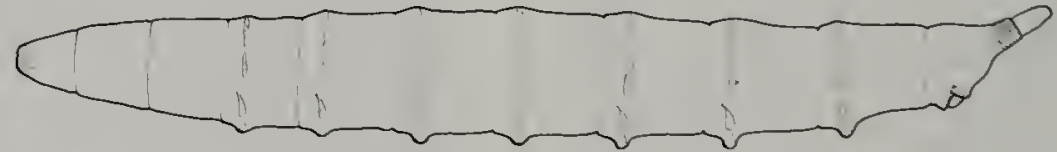

195 nigrioes

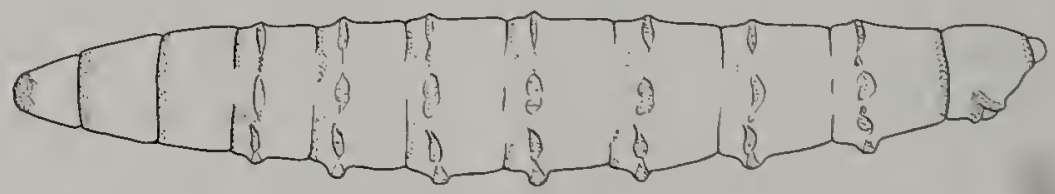

196 'invulus

Fig. 190-196.-Larvae. 190. Tabanus americanus. 191. T. pumilus. 192. T. fairchildi. 193. T. marginalis. 194. T. melanocerus. 195. T. nigripes. 196. T. fulvulus. 

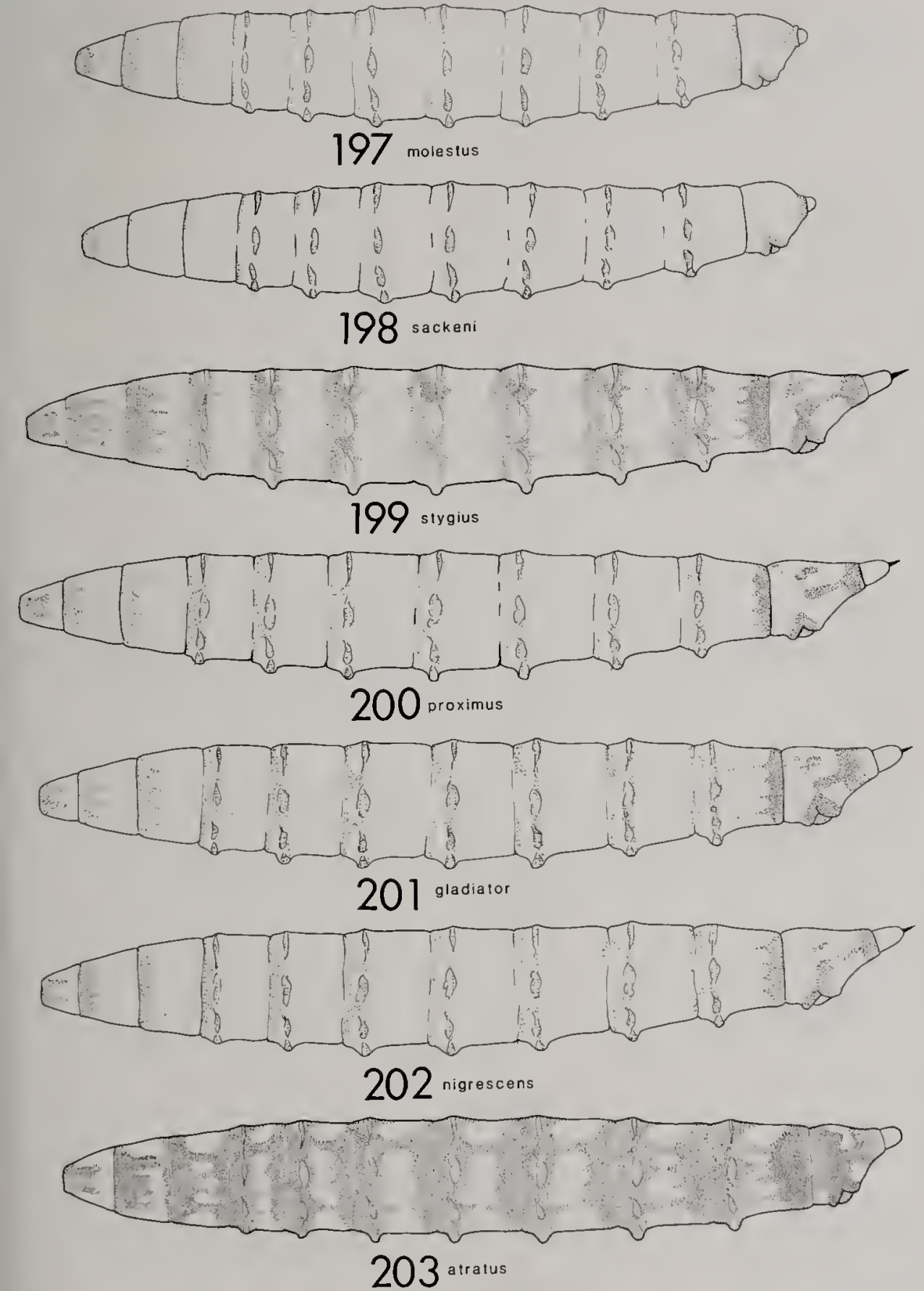

Fig. 197-203.-Larvae. 197. Tabanus molestus. 198. T. sackeni. 199. T. stygius. 200. T. proximus. 201. T. gladlator. 202. T. nigrescens. 203. T. atratus. 


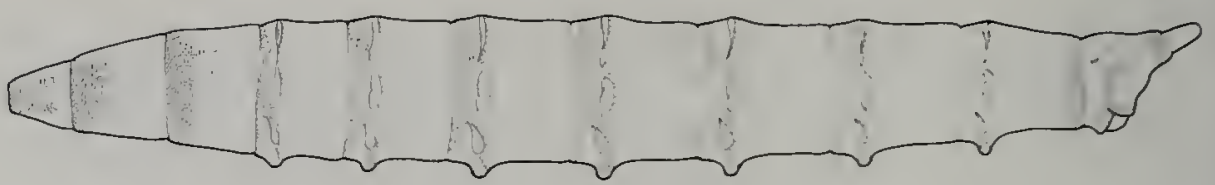

204 suereriumentarius
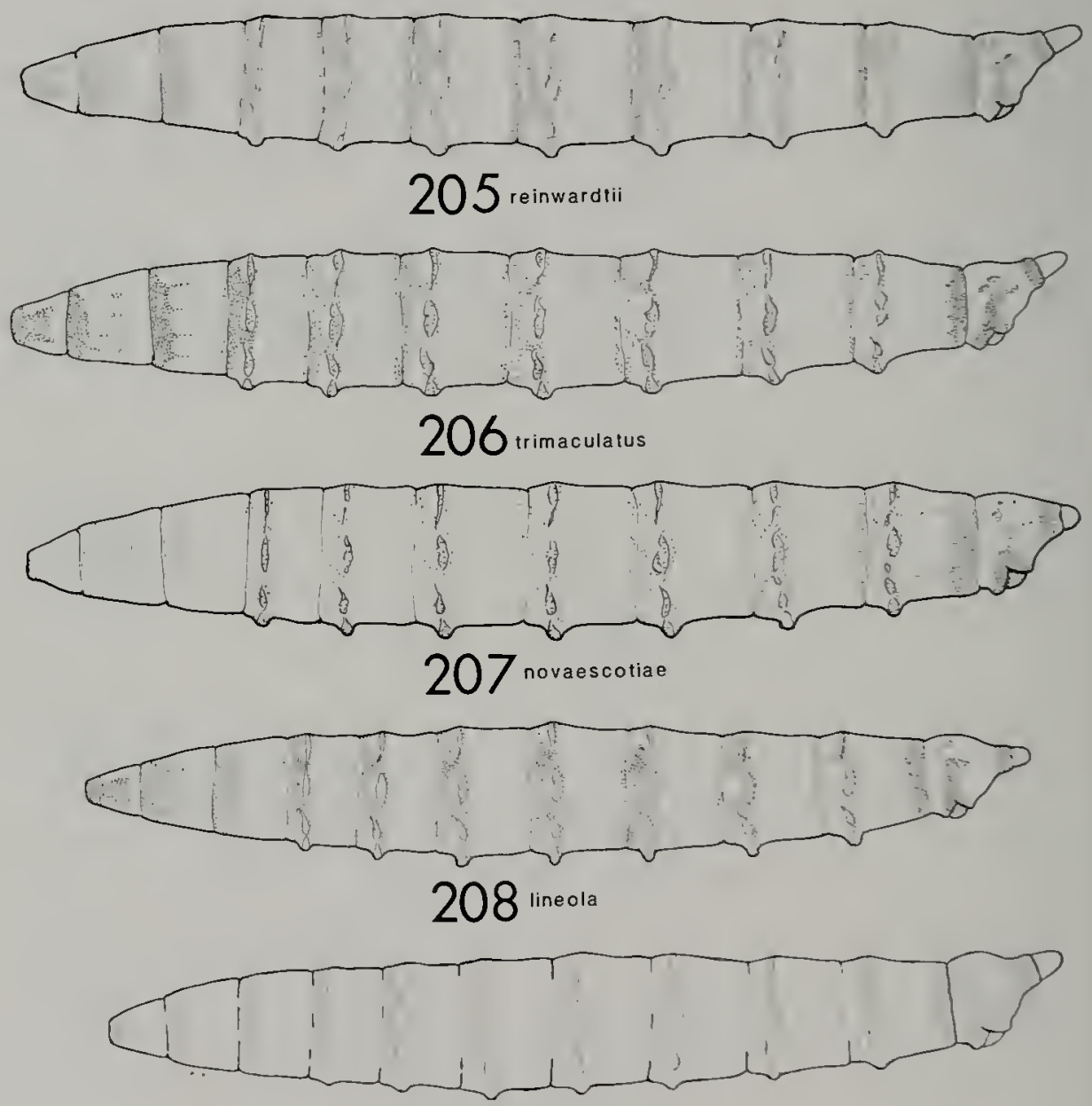

209 similis

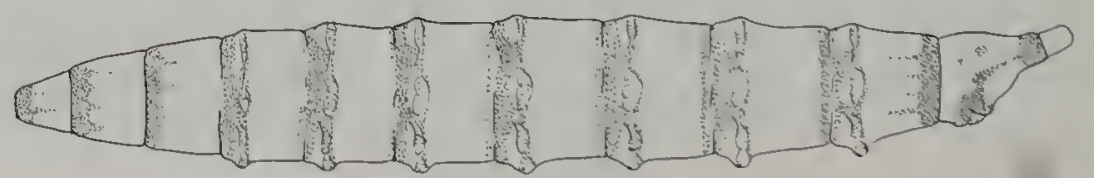

210 imbatinevris

Fig. 204-210.-Larvae. 204. Tabanus superjumentarius. 205. T. reinwardtii. 206. T. trimaculatus. 207. T. novaescotiae. 208. T. lineola. 209. T. similis. 210 . T. limbatinevris. 


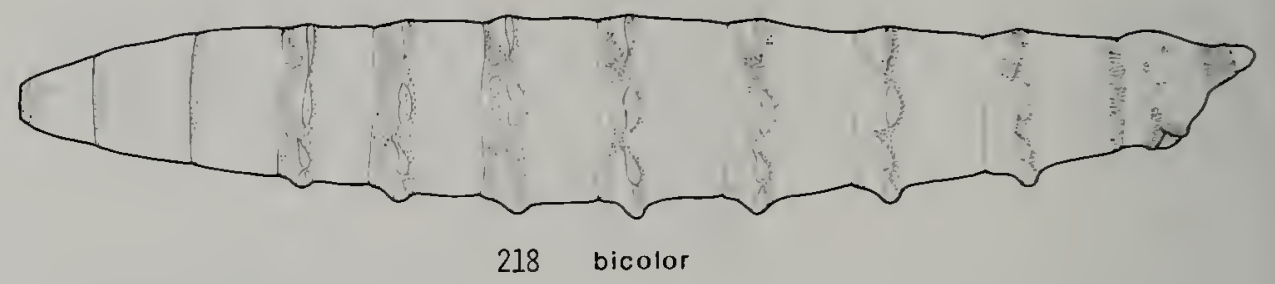

Fig. 218.-Atylotus bicolor larva.

22. Midlateral caudal projection from lateral pubescent figure on anal segment united with posterior annulus; mature larvae 12-15 $\mathrm{mm}$ long (Fig. 214) ......

Midlateral caudal projection from lateral pubescent figure on anal segment separated from posterior annulus; mature larvae $16-25 \mathrm{~mm}$ long 23

23. Posterior pubescence present on abdominal segments $2-8$ and encircles last 3 or 4 segments (Fig. 215, 216) . .24

Posterior pubescence present on abdominal segments 5-8 and usually encircles only last 2 segments (Fig. 213). quinquevittatus

24. Anterior pubescence on meso- and metathorax interrupted dorsally and ventrally (Fig. 217)

Atylolus woodi

Anterior pubescence encircles mesoand metathorax

25. Pubescence pale; anterior pubescence encircles abdominal segments 1-7; caudal projections from prothoracic annulus slender and tapered (Fig. 215) Atylotus thoracicus

Pubescence moderately dark; anterior pubescence encircles abdominal segments 1-5; lateral caudal projections from prothoracic annulus expanded posteriorly (Fig. 216)..Atylotus ohioensis

26. Posterior pubescence present on all abdominal segments, encircles at least last 4 segments

Posterior pubescence present on no more than last 4 segments, encircles no more than last 3 segments (Fig. 212. 218)

27. Anal segment and respiratory siphon longer than their greatest diameters, latter about 1.5 times longer

Anal segment and respiratory siphon about equal in length to their greatest diameters (Fig. 209)

similis, subsimilis

28. Anterior pubescence encircles first $7 \mathrm{ab}-$ dominal segments (Fig. 210).

limbatinevris

Anterior pubescence encircles first 3 or 4 abdominal segments (Fig. 211) sulcifrons

29. Posterior pubescence encircles last 3 abdominal segments; meso- and metathoracic annuli with caudal projections
(Fig. 212) calens

Posterior pubescence encircles only last 2 abdominal segments; meso- and metathoracic annuli lack slender caudal projections (Fig. 218)

Atylotus bicolor

\section{Tabanus abdominalis Fabricius}

Tabanus abdominalis Fabricius (1805:96). Type-locality: Carolina.

Fairly large $(20.75 \mathrm{~mm})$; orange and black; frons very narrow; averaging slightly over six times as high as width at base, slightly widened above (Fig. I88); second palpal segment so densely covered with short black hair that segment appears black; wing tinted with dark spots and dark yellow costal cell; first posterior cell may be slightly open at margin. closed, or short petiolate; femora deep black with black hairs; tibiae orange at base, black toward apex; abdomen orange with black median spots, which may have indistinct pale triangles superimposed, or all spots may be nearly obsolete so entire abdomen appears orange; venter orange yellow. Male easily associated with female, except that first posterior cell moderately narrowed or wide open: upper eye facets only slightly differentiated from lower facets; eyes bare.

This species has had other species confused with it, and literature records should be used with caution. A discussion of the taxonomy of $T \cdot a b$ dominalis may be found under $T$. limbatinerris.

The larva is unknown. The larva of T. abdominalis described by Goodwin (1973b) apparently is that of $T$. limbatinerris.

In Illinois adults appear in nid-July and have been collected until September. 
T. abdominalis ranges from Texas to Florida and north to Virginia and Kentucky. In Illinois it has been collected only in the southern third of the state, and this seems to mark the northern extent of its range (Fig. 219).

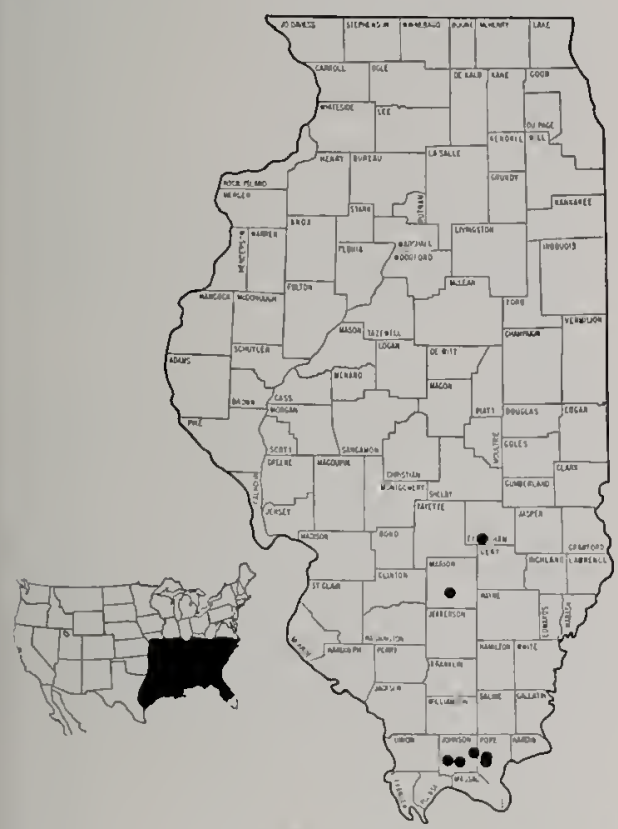

Fig. 219.-Distribution of Tabanus abdominalls in Illinois and North America.

\section{Tabanus americanus Forster}

Tabanus americanus Forster (1771:100). Type-locality: Virginia and New York. Tabanus plumbeus Drury (1773:2). Typelocality: Virginia and New York.

Tabanus ruficornis Fabricius (1775:789). Type-locality: America.

Tabanus limbatus Palisot de Beauvois

(1806:54). Type-locality: United

\section{States.}

Large $(24 \mathrm{~mm})$; reddish brown; subcallus not denuded; palpi pale to reddish brown; eye bare; wing hyaline with dark brown costal cell; abdomen with narrow pale bands on hind margins of segments. Male eye facets distinctly differentiated; eyes bare.

This species is the largest horse fly in North America, sometimes reaching a length of $30 \mathrm{~mm}$.

Larvae (Fig. 190) have been found in decaying logs and along margins of ponds as well as in the moist areas of the forest floor (Tidwell 1973).

In Illinois adults appear in late June and have been collected until late July.

T. americanus is a southeastern species, extending from the southern tip of Florida to New Hampshire and west to eastern Texas (Fig. 220) with a disjunct, and possibly not permanent, distribution in southern Ontario and Michigan. In Illinois this species is only found in the southern third of the state (Fig. 220).

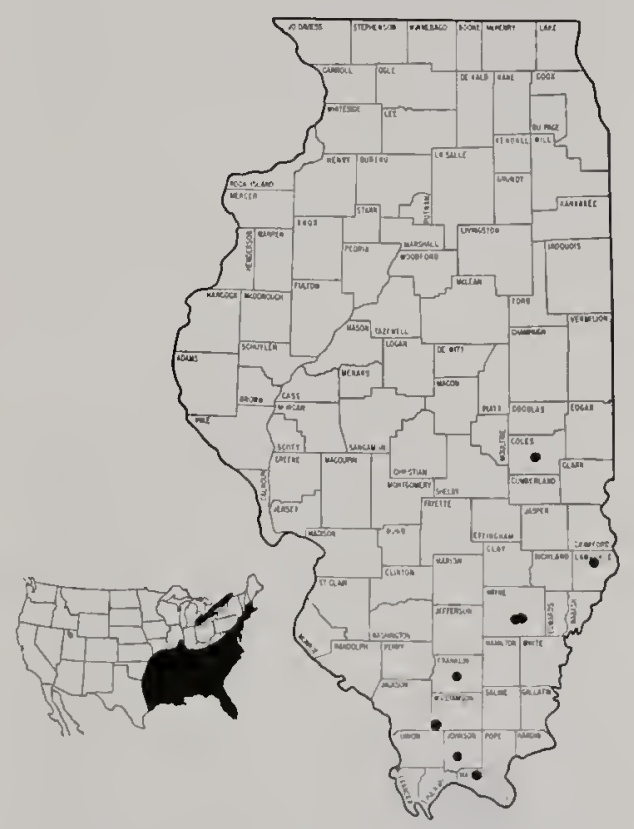

Fig. 220.-Distribution of Tabanus americanus in Illinois and North America.

Tabanus atratus atratus Fabricius

Tabanus atratus Fabricius (1775:789).

Type-locality: America.

Tabanus americanus Drury (1773:2).

Type-locality: New York.

Tabanus niger Palisot de Beauvois

(1806:54). 'Type-locality: Pennsylvania. Tabanus validus Wiedemann (1828:113).

Type-locality: Pennsylvania, Philadelphia.

Large $(24 \mathrm{~mm})$; black, subcallus denuded; eye bare; wing unilormly dark brown to black; abdomen some- 
times with a whitish or bluish bloom. Male eye facets distinctly differentiated; eyes bare.

The eggs are laid on grass or leaves over marshy areas or streams and also on concrete bridge abutments. The larvae (Fig. 203), which can be found throughout the year, live in moist earth or in water and seem to tolerate a wide range of moisture conditions (Jones \& Bradley 1923; Pechuman 1972; Teskey 1969; Tidwell 1973). The life cycle is usually completed in 1 year, but some individuals require 2 years and possibly more.

In Illinois adults appear in late May and have been collected until early September.

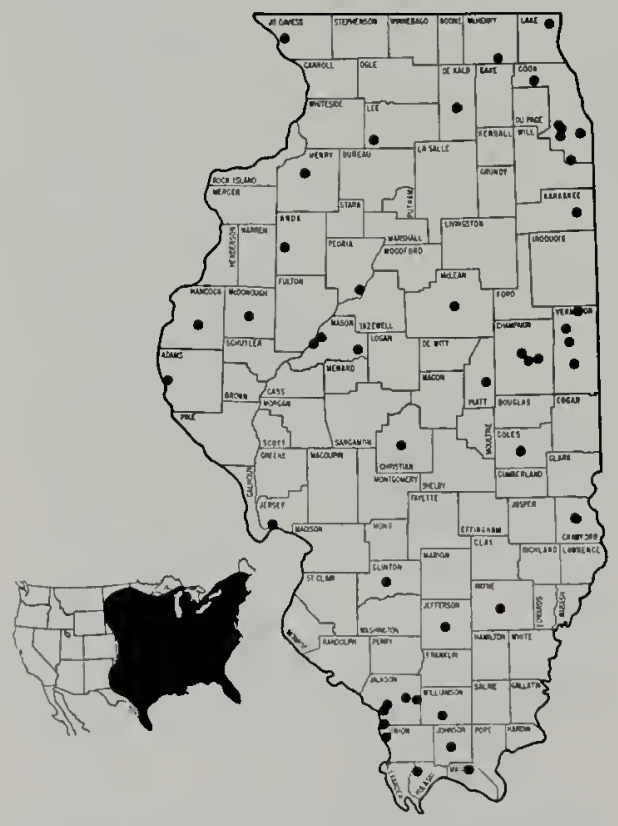

Fig. 221.-Distribution of Tabanus atratus atratus in Illinois and North America.

T. atratus atratus is a widely distributed species, extending from the southern tip of Florida to Maine and west to North Dakota and into the northeastern corner of Mexico (Fig. 221). In Illinois this species has been collected throughout the state (Fig. 221).

\section{Tabanus calens Linnaeus}

Tabanus calens Linnaeus (1758:601). Type-locality: America.

Tabanus giganteus De Geer (1776:226). Type-locality: Pennsylvania.

Tabanus lineatus Fabricius (1781:455). Type-locality: America.

Tabanus pallidus Palisot de Beauvois (1809:100). Type-locality: United States.

Tabanus bicolor Macquart (1847:37). Type-locality: South Carolina. Name preoccupied (Wiedemann 1821).

Tabanus coesiofasciatus Macquart (1855: 52). Type-locality: Maryland, Baltimore.

Large $(24 \mathrm{~mm})$; subcallus not denuded; palpi pale to reddisn brown: eyes bare; thorax brown with indistinct reddish lines; wing pale yellowish with costal cell darker; abdomen blackish, sometimes with faint, pale, median triangles (Fig. 160). Male eve facets show little differentiation and line of demarcation not distinct; pale median triangles of abdomen, when

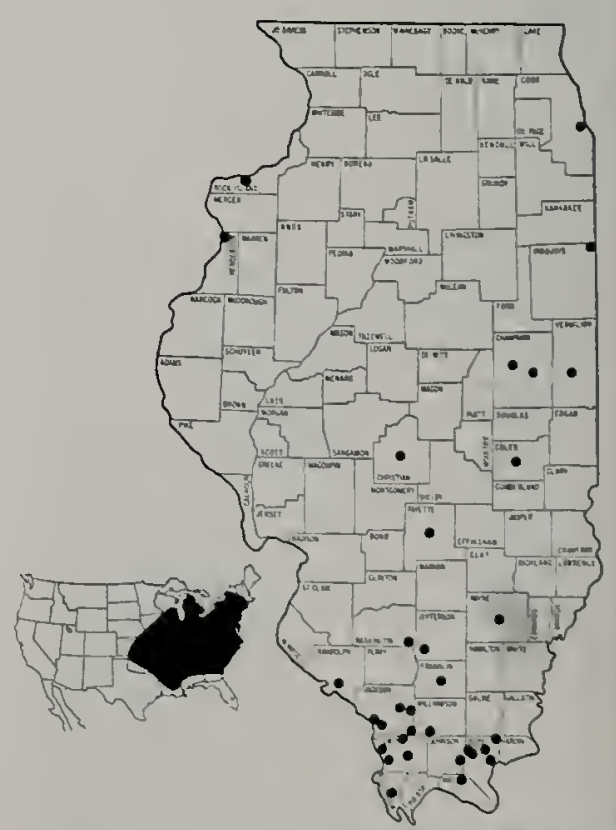

Fig. 222.-Distribution of Tabanus calens in Illinois and North America. 
present, usually larger than in female; eyes bare.

This species name was unrecognized for many years, and generally was called T. giganteus De Geer. However, Linnaeus's name seems to be correctly associated with this species (Philip 1952).

Larvae (Fig. 212) have been collected in damp pasture sod (Teskey 1969).

In Illinois adults appear in mid-July and have been collected until midSeptember. Although this species flies throughout the day, most activity is at dusk, when large numbers may suddenly appear and attack animals and humans. The males hover at dusk.

T. calens is an eastern and central species, extending from Georgia to Massachusetts and west to Arkansas (Fig. 222). In Illinois this species is collected throughout the state (Fig. 222).

\section{Tabanus cymatophorus Osten Sacken}

Tabanus cymatophorus Osten Sacken (1876:444). Type-locality: Kentucky, Mammoth Cave.

Rather large (19 mm); brownish gray

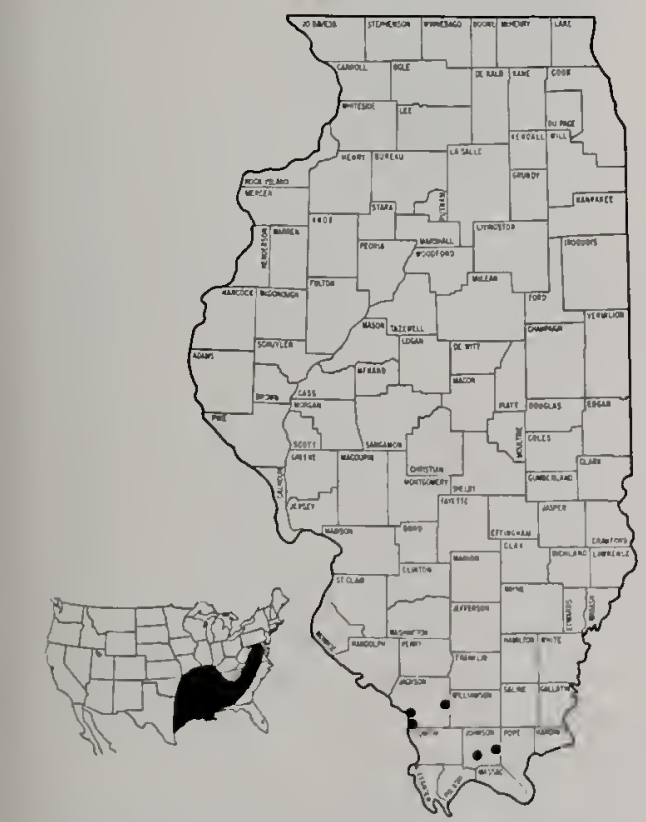

Fig. 223.-Distribution of Tabanus cymatophorus in Illinois and North America. with three rows of abdominal spots, which are confluent along hind margins (Fig. 172); frons narrow, 4.5 times as high as wide; wings with brown spots on crossveins and bifurcation; pleural hairs and beard white. Male easily associated with female; upper eye facets enlarged, occupying about two-thirds of eye area, distinctly set off from small facets.

A larva (Jones \& Bradley 1924) has been taken from the margins of a shallow pool.

In Illinois adults appear in early July and have been collected until late August.

T. cymatophorus is a southeastern species, extending from Mississippi to Maryland and west to Texas (Fig. 223). In Illinois this species has been collected only in the southern part of the state (Fig. 223).

\section{Tabanus equalis Hine}

Tabanus equalis Hine (1923:205). Typelocality: Kansas, Jackson County.

Tabanus uniformis Hine (1917:270). Type-

locality: Kansas, Jackson County.

Name preoccupied (Ricardo 1911).

Large size $(20 \mathrm{~mm})$; brownish with rather faint wing spots on crossveins and bifurcation; costal cell hyaline or somewhat tinted; fore tibiae uniform in color; abdomen with median row of gray triangles, sometimes indistinct (Fig. 186). Male readily associated with female; upper eye facets moderately enlarged, cover about two-thirds of eye area.

Schomberg \& Howell (1955) found the larvae to be terrestrial. They were present up to a depth of $10 \mathrm{~cm}$ in well drained, grass covered soil in the shade of trees. The adults are most abundant at dusk, and males hover at that time. Males have frequently been taken at lights at night.

In 1 llinois adults appear in micl-April and have been collected until late July.

T. equalis is a central species, extending from Louisiana to southern lndiana 
and west to Kansas and Texas (Fig. 224). In Illinois this species is widespread in the southern two-thirds of the state (Fig. 224).

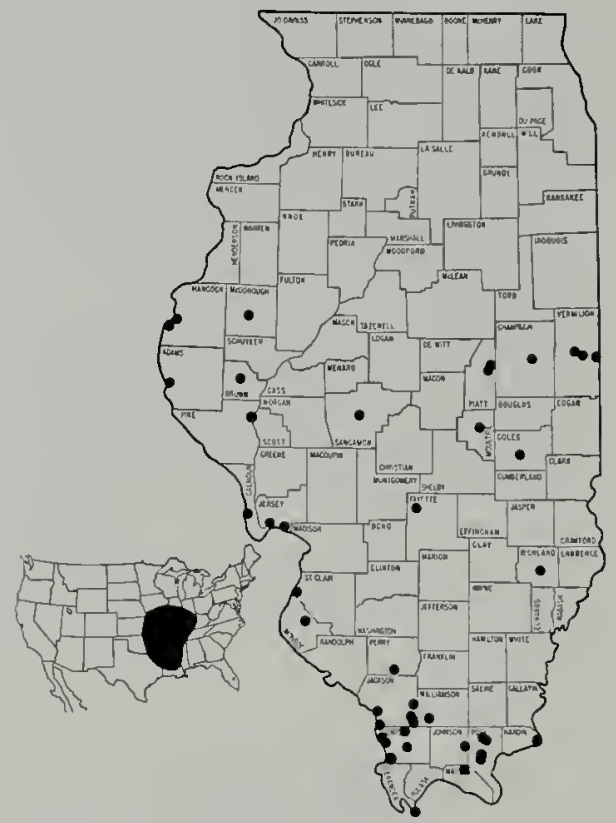

Fig. 224.-Distribution of Tabanus equalis in Illinois and North America.

\section{Tabanus exilipalpis Stone}

Tabanus exilipalpis Stone (1938:54). Typelocality: South Carolina, Beaufort.

Rather small $(11.5 \mathrm{~mm})$; eye with very short, sparse pile; palpi very slender, slightly thickened at base; basal plate of antenna rather broad with distinct angle; frons narrow, 4 times as high as width at base; beard white; wings hyaline, including costal cell; legs yellowish brown; abdomen dark brown with pale median stripe, which widens at apex of each segment, segments 2-5 with round pale sublateral spots. Male with densely pilose eyes; occipital border with long black hairs recurved anteriorly: eye facets essentially one size.

The hair on the eyes of females may easily be overlooked. but the combination of slender palpi, the median stripe on the abdomen, and rounded sublateral spots will separate this species from most other species likely to be found in Illinois.

The larva and biology of this species are unknown.

T. exilipalpis is a central and southern species, extending from Alabama north to western Kentucky, apparently. with a disjunct population along the coast of South Carolina (Fig. 225). As yet this species has not been collected in Illinois although specimens have been examined from western Kentucky.

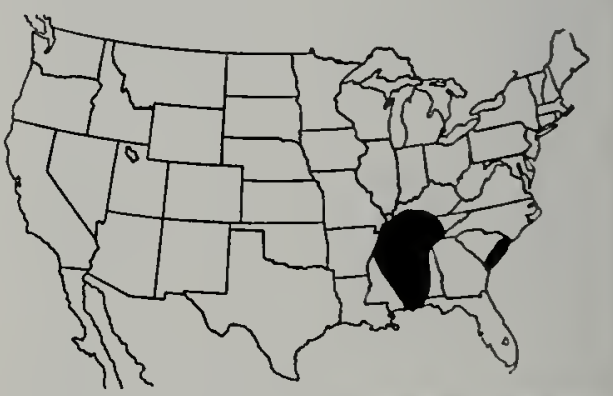

Fig. 225.-Distribution of Tabanus exilipalpis in North America.

\section{Tabanus fairchildi Stone}

Tabanus fairchildi Stone (1938:63). Typelocality: New York. Taghkanic, near Ithaca.

Moderate size (14 mm); blackish brown; antennae black, with first segment swollen above; sides of subcallus with few hairs laterally; eyes bare or with short, scattered hairs; thorax does not strongly contrast with abdomen: wing hyaline; bifurcation of third longitudinal vein without a dark spot; abdomen with 3 rows of pale spots (Fig. 176). Male eye facets somewhat differentiated, but line of demarcation not distinct; eyes often with short. scattered hairs but sometimes apparently bare.

This species was long confused with T. vivax, and most references to that species before 1938 actually refer to $T$. fairchildi. It is not commonly netted in the field and does not seem to be a serious pest of livestock.

The larvae (Fig. 192) differ from most tabanids in that they occur in 
swiftly flowing streams. The eggs are placed on projecting stones or logs in riffles, and often many females deposit their eggs on the same object, resulting in the accumulation of several hundred egg masses. The larvae are found under stones, often in the swiftest part of the stream. They probably pupate in mud on the edge of the stream (Pechuman 1972; Teskey 1969; 'Tidwell 1973). Tidwell (1973) also reports finding larvae beneath a layer of moss on a partially submerged $\log$ in a beaver dam.

In Illinois adults appear in early June and have been collected until late July.

T. fairchildi is a widespread species, extending from the panhandle of Florida to Maine and west to Kansas and Oklahoma (Fig. 226). This species has been collected only infrequently in Illinois.

Illinois Records.-Pope County, Herod, Lusk Creek; Vermilion County, Oakwood.

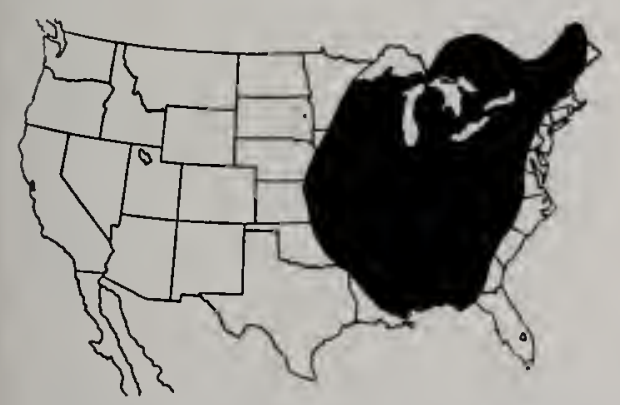

Fig. 226.-Distribution of Tabanus falrchildl in North America.

\section{Tabanus fulvulus Wiedemann}

Tabanus fulvulus Wiedemann (1828:153). Type-locality: America.

Tabanus fulvofrater Walker (1848:181). Type-locality: Illinois.

Tabanus mutatus Walker (1850:23). Typelocality: United States.

Moderate size (14 $\mathrm{mm}$ ); yellowish to orange; palpi yellow; frons very narrow and widened above; third antennal segment moderately broad, orange, annuli black; eyes bare; thoracic dorsum without stripes; wing hyaline, costal cell colored: abdomen with yellow median line of large contiguous triangles and sublateral yellow spots (Fig. 166). Male eye facets differentiated but not markedly so; eyes bare.

Larvae (Fig. 196) have been taken from well drained, leaf covered soils of a mixed pine-hardwood forest in Louisiana (Tidwell \& Tidwell 1973).

In Illinois adults appear in early June and have been collected until early September.

T. fuloulus is a southern and central species, extending from southern Florida to Long Island, New York and west to Wisconsin and Oklahoma (Fig. 227). In Illinois this species has been collected in the southern two-thirds of the state (Fig. 227).

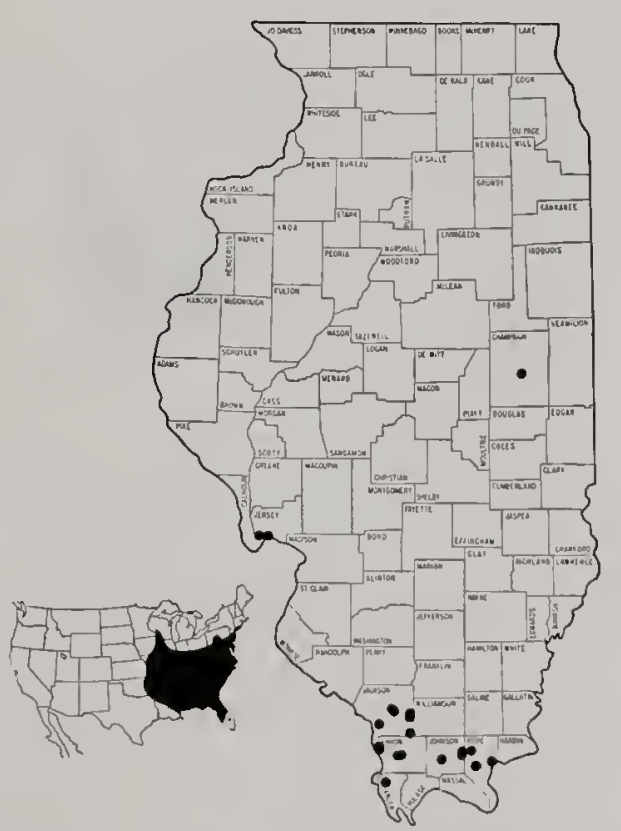

Fig. 227.-Distribution of Tabanus fulvulus in Illinois and North America.

\section{Tabanus gladiator Stone}

Tabanus gladiator Stone (1935:12). Typelocality: South Carolina, Charleston. Large size (23 $\mathrm{mm}$ ); orange brown with lavender thorax; frous very narrow, slightly widened above: pilpi long, straplike, eacli with truncate apex; cos- 
tal cell deep yellow, brown spots on crossveins and bifurcation; first posterior cell narrowed at margin; all femora black; abdomen orange brown, somewhat darker in center. Male easily associated with female; upper eye facets scarcely enlarged, line of demarcation indistinct; black median areas of abdomen more evident than in female.

Larvae (Fig. 201) have been collected in the upper $2 \mathrm{~cm}$ of mud and organic debris at the margins of small ponds or lakes (Goodwin 1973b).

T. gladiator is a southeastern species, extending from southern Florida to Maryland and west to eastern Texas (Fig. 228). As yet this species has not been collected in Illinois although specimens have been examined from western Kentucky.

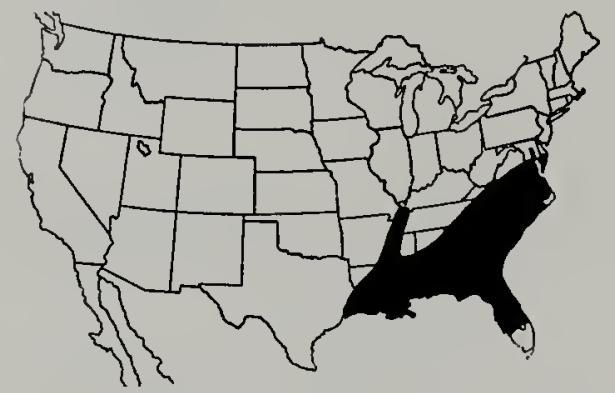

Fig. 228.-Distribution of Tabanus gladiator in North America.

\section{Tabanus limbatinevris Macquart}

Tabanus limbatinerris Macquart (1847:32).

Type-locality: unknown (stated by Macquart to be Tasmania).

Tabanus abdominalis Osten Sacken (1876: 434), not Fabricius (1805:96). Misidentification.

Fairly large $(19.5 \mathrm{~mm})$; reddish brown; frons rather narrow, averaging $5 \frac{1}{3}$ times as high as width at base, slightly widened above (Fig. 189); second palpal segnent yellowish with short black hair; wing tinted, with dark spots and yellow costal cell; first posterior cell normally petiolate, occasionally closed at margin or narrowly open; femora black to brown. usually with mixture of black and yellow hairs; fore tibiae pale yellow on basal one-third to one-half, balance of segment black or brown; middle and hind tibiae yellow; somewhat darker near apex; abdomen dull reddish brown with middorsal row of pale triangles; venter dark yellow with trace of dark median markings. Male lacks diagnostic characters of narrower frons and petiolate first posterior cell, which separate the female from T. sulcifrons; line of demarcation setting off larger upper eye facets straight or slopes slightly upward; in most sulcifrons, line sinuate and slopes downward before bending upward along lateral margins of eyes. A dark form of $T$. sulcifrons (which may be a distinct species) has eve structures similar to those of limbatinerris, but all I [Pechuman] have seen have the first two antennal segments dark brown or black rather than the yellow or yellowbrown of limbatinevris; also in this form the length of the second palpal segment is 2 to 2.37 times its greatest thickness, while in limbatinerris the length is 1.8 to 1.9 times the greatest thickness.

Tabanus limbatinerris has not been recognized as a distinct species since it was described. Macquart thought his specimen came from Tasmania, but Philip (I959:208) recognized the type in the British Museum (Natural History) as Nearctic and placed it as a synonym of abdominalis Fabricius. At the same time he mentioned that the two syntypes of abdominalis in the Paris Museum were the form "with bright orange abdomens and reduced median spots, plus closed cell $\mathbf{R}_{5}$." This finding was confirmed by Osten Sacken (1878), who also saw Fabricius' types.

Earlier, however, Osten Sacken (1876) had redescribed as abdominalis a smaller, browner form. In 1878. apparently after seeing Fabricius' types, he stated that his original redescription was based on "a small and very abnormally colored specimen...." Through the kindness of Mrs. Margaret $k$. Thayer we were able to study Osten Sacken's material in the Museum of Comparative 
Loology. Une specimen had a note on the pin in Osten Sacken's handwriting which said, "Specimen from which I made my first description of T. abdominalis. It is very doubtfully one; may be a $T$. exul with an adventitiously closed cell!" This specimen closely matches the type of T. limbatinevris kindly lent to us by Mr. J. E. Chainey of the British Museum (Natural History). Osten Sacken's other specimens from Kentucky on which his subsequent redescription of abdominalis was based (1878) are abdominalis.

For additional confirmation, we sent one specimen each of limbatineuris and abdominalis to Dr. L. Tsacas, Museum National d'Histoire Naturelle, Paris, for comparison with the types of abdominalis. In a number of characters, the specimen of the species we are calling abdominalis matched Fabricius' types. The type-specimen of abdominalis has the first posterior cell closed at the margin in the left wing and short petiolate in the right wing, according to Dr. Tsacas. The cooperation of Dr. Tsacas in this investigation is greatly appreciated.

Workers subsequent to Osten Sacken included limbatinerris with abdominalis or sulcifrons. Based on a number of specimens with his determination label, Stone (1938) placed limbatinevris with sulcifrons. Numerous specimens of the three species involved were studied, and a summary of this study is given in Table 1.

The larvae (Fig. 210) described as $T$. abdominalis (Goodwin 1973b) have been collected along the margin of a slough in the upper $2-5 \mathrm{~cm}$ of mud just at the water line.

In Illinois adults appear in early July and have been collected until late August, with most collections in August.

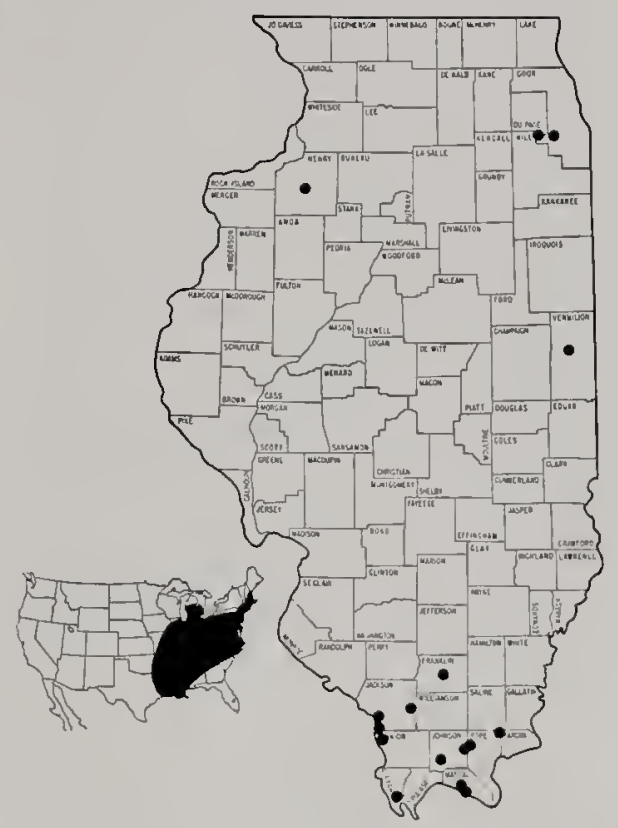

Fig. 229.-Distribution of Tabanus limbatinevris in Illinois and North America.

Table 1.-Comparison of body length, frons ratio, and first posterior cell in Tabanus abdominalis, T. limbatinevris, and T. sulcifrons.

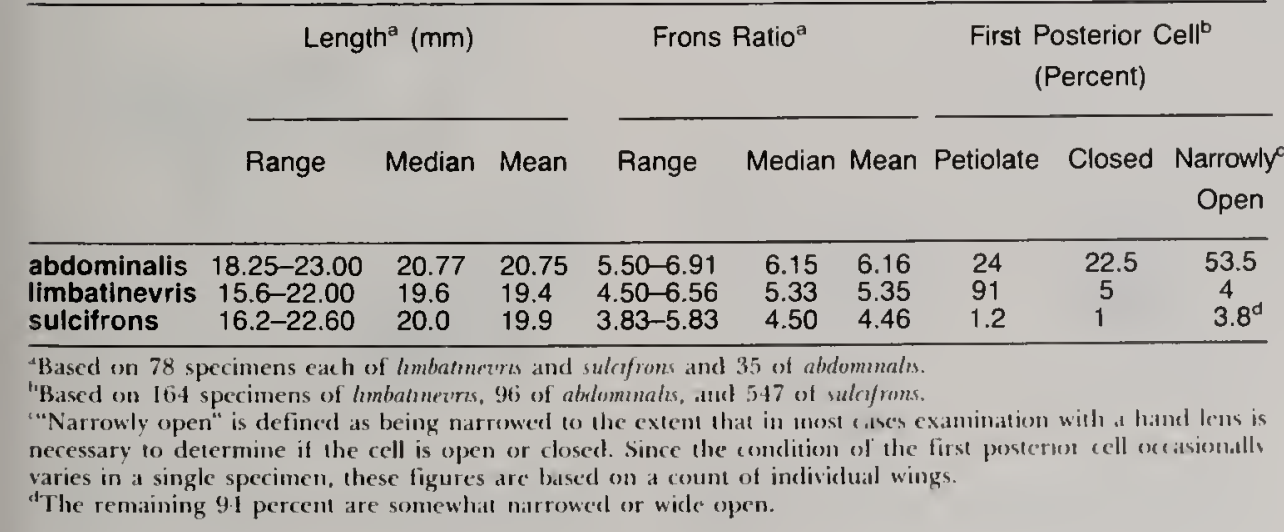


The North American range of $T$. limbatinevris is shown in Fig. 229. In New England it seems to be confined largely to coastal areas. It is rather widely distributed in Illinois (Fig. 229), but the bulk of the records are from the more southern counties.

Tabanus lineola Fabricius

Tabanus lineola Fabricius (1794:369).

Type-locality: North America.

Moderate size $(13 \mathrm{~mm})$; yellowish, brown, or nearly black; frons narrow, distinctly widened above; median callus slender; eyes bare; annulate portion of third antennal segment usually shorter than basal portion; scutellum entirely dark; prescutal lobes usually paler than mesonotum; wing hyaline; hind femora mostly dark; abdomen with pale median stripe and variable sublateral stripes (Fig. 161). Male eye facets distinctly differentiated; eyes bare.

Specimens collected in Illinois are generally of the melanistic form of this species.

Larvae (Fig. 208) have been collected from a wide variety of habitats,

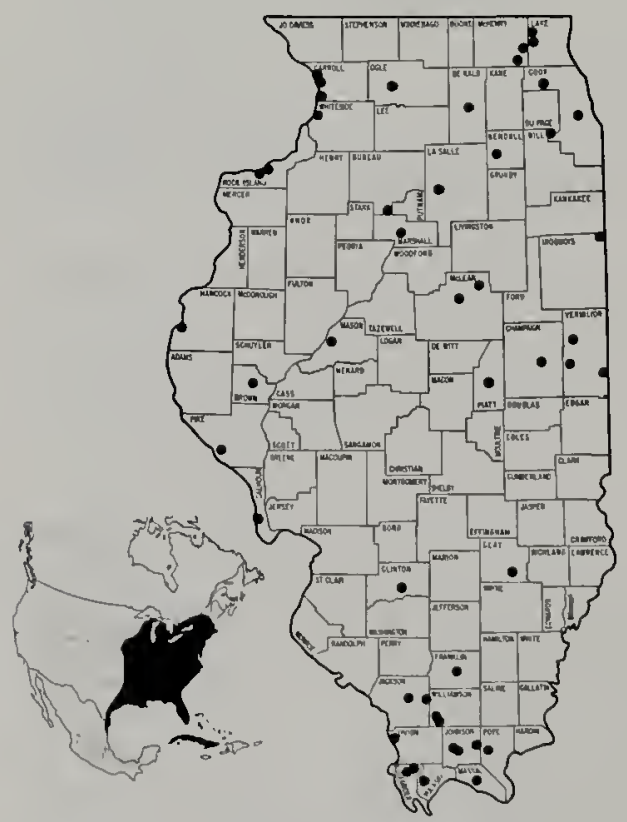

Fig. 230.-Distribution of Tabanus lineola in lilinois and North America. including moist forest soil, margins of ponds and streams, wooded swamps, and bogs (Pechuman 1972; Teskey 1969; Tidwell 1973).

In Illinois adults appear in early June and have been collected until mid-September.

T. lineola is a widespread east-central species, extending from Cuba to southern Quebec and west to South Dakota and southern Texas (Fig. 230). In Ilinois this species is widespread throughout the state (Fig. 230).

\section{Tabanus marginalis Fabricius}

Tabanus marginalis Fabricius (1805:99).

Type-locality: North America.

Tabanus nivosus Osten Sacken (1876:

445). Type-locality: New Jersey.

Moderate size $(13 \mathrm{~mm})$; blackish brown; first antennal segment not swollen above; sides of subcallus without hairs; eyes bare; wing hyaline; bifurcation of third longitudinal vein without brown spot; abdomen with three rows of pale spots, median row being much smaller than sublateral rows (Fig. 177). Male eye facets distinctly differentiated; sublateral abdominal spots of eren

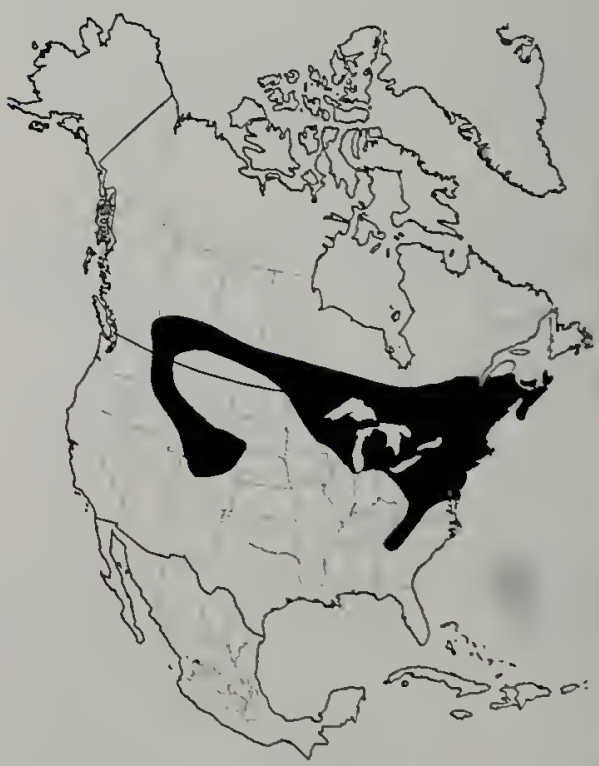

Fig. 231.-Distribution of Tabanus marginalis in North America. 
greater extent than those of fenale; eyes bare.

Larvae (Fig. 193) have been found in a wide range of saturated freshwater habitats (Pechuman 1972; Teskey 1969).

In Illinois adults appear in early August.

T. marginalis is a northern species, extending from northeastern Georgia to Cape Breton, Nova Scotia, and west in a narrow band to British Columbia and Colorado (Fig. 231). This species has been collected only once in Illinois in 1906.

Illinois Records. - Lake County, Sun Lake.

\section{Tabanus melanocerus Wiedemann}

Tabanus melanocerus Wiedemann (1828:

122). Type-locality: Kentucky.

Moderate size $(17 \mathrm{~mm})$; dark brown to blackish; subcallus pollinose; eyes bare; thorax does not contrast strongly with abdomen; wing hyaline or tinged faintly yellowish, costal cell sometimes yellow; first posterior cell much narrowed, sometimes closed at wing margin; bifurcation of third longitudinal vein without brown spot; fore tibiae pale, dark at apex; abdomen with median row of pale triangles and tergites with narrow, sometimes obsolete, pale bands on hind margins (Fig. 183). Male eye facets distinctly differentiated; eyes bare.

Larvae (Fig. 194) have been taken from mud and organic debris at the edges of streams, ditches, and lakes

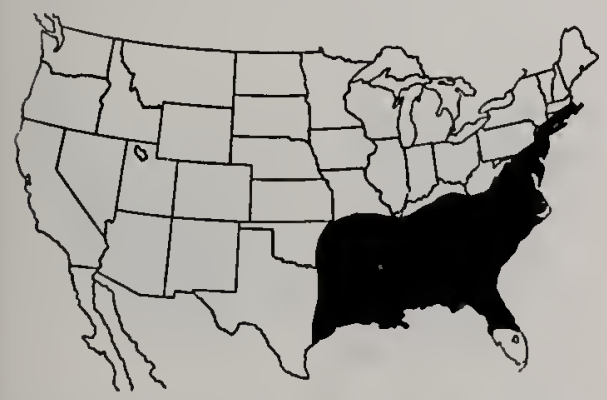

Fig. 232.-Distribution of Tabanus melanocerus in North America.
(Pechuman 1972; Teskey 1969; Tidwell 1973).

T. melanocerus is a southern and eastern species, extending from southern Florida to Massachusetts and west to Oklahoma and Texas (Fig. 232). As yet this species has not been collected in llinois although specimens have been examined from western Kentucky.

\section{Tabanus molestus molestus Say}

Tabanus molestus molestus Say (1823:31).

Type-locality: Missouri.

Atylotus tenessensis Bigot (1892:660).

Type-locality: Tennessee.

Fairly large $(19 \mathrm{~mm})$; dark brown with dorsum of thorax, including scutellum, white pollinose except for small dark spot just anterior of scutellum; legs rather uniformly dark brown; wing spots on crossveins and bifurcation distinct but rather faint; pale median spot on second tergite smaller than those on tergites 3 and 4 (Fig. 179). Male eye facets enlarged, sharply set off; dorsum of thorax dark brown except scutellum, which is white haired and pollinose as in female; abdomen with median triangles expand-

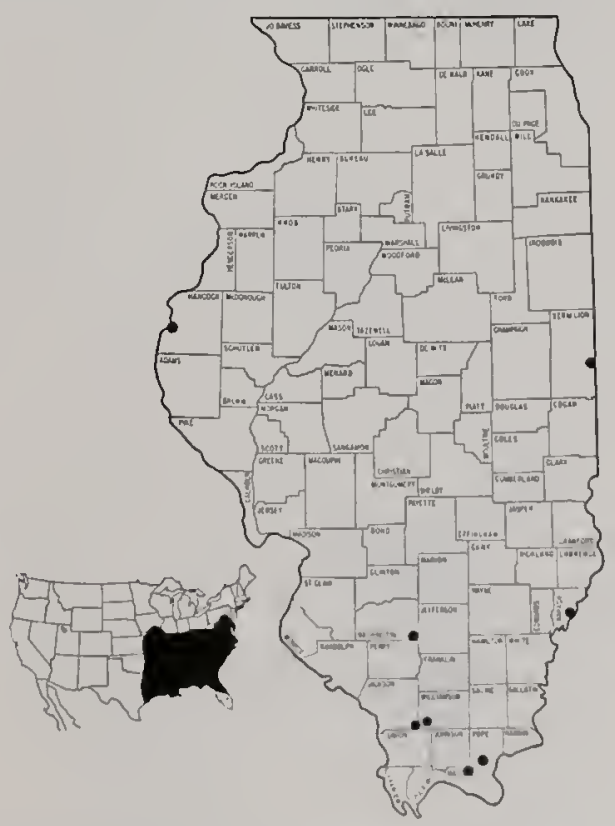

Fig. 233.-Distribution of Tabanus molestus molestus in Illinois and North America. 
ed more extensively laterally than in female.

Tidwell (1973) found the larvae (Fig. I97) beneath moss on banks of streams well above the high-water mark, and Thompson et al. (1978) report a larva from the shoreline of a slough.

In Illinois adults appear in early June and have been collected until late August.

T. molestus molestus is a southeastern subspecies, extending from central Florida to New York and west to Iowa and eastern Texas (Fig. 233). This subspecies has been collected infrequently in the southern half of Illinois (Fig. 233).

\section{Tabanus mularis Stone}

Tabanus mularis Stone (1935:15). Typelocality: Louisiana, Baton Rouge.

Rather small (11 mm); palpi, cheeks, and beard white; costal cell dark yellow to brown, rest of wing hyaline; abdomen blackish with yellow median parallel sided stripe, indefinite orange brown near lateral margins of tergites. Male colored essentially like female; upper eye facets enlarged, line of demarcation distinct.

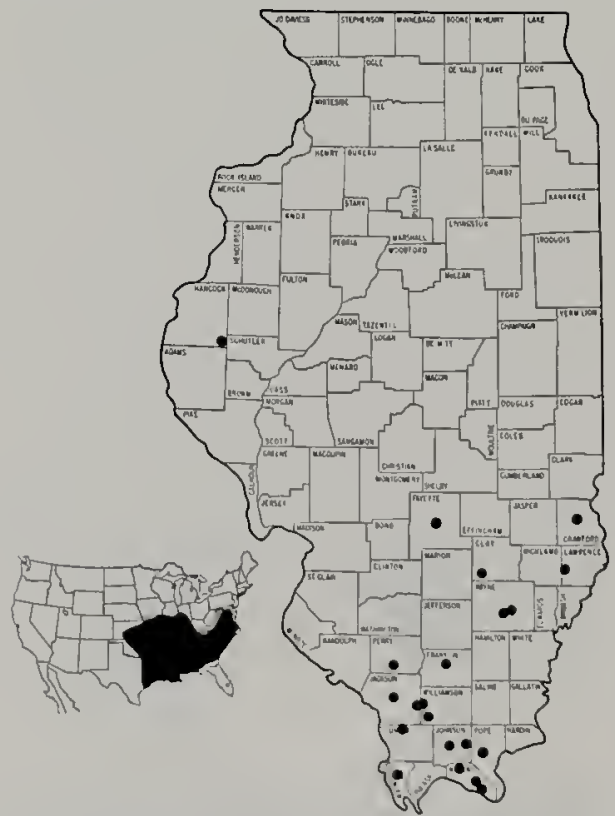

Fig. 234.-Distribution of Tabanus mularis in Illinois and North America.
The larva of this species has not been recognized. See the discussion under Tabanus quinquevittatus.

In Illinois adults appear in mid-June and have been collected until midAugust.

T. mularis is a central and southeastern species, extending from the panhandle of Florida to Maryland and west to Missouri and eastern Texas (Fig. 234). In Illinois this species has been collected in the southern twothirds of the state (Fig. 234).

Tabanus nigrescens Palisot de Beauvois

Tabanus nigrescens Palisot de Beauvois (1809:100). Type-locality: United States.

Large size (22 mm); black; subcallus not denuded; palpi dark brown to black; facial setae black; eves bare; mesonotum dark brown; wing pale yellowish with dark spots, dark costal cell. deeper color in basal cells and base of discal cell. Male eye facets distinctly. differentiated; thorax often with brownish tinge; eyes bare.

Larvae (Fig. 202) have been collected from the margin of a beaver pond (Tidwell 1973) and from mud on edges of marshes, lakes, and small woodland streams (Goodwin 1973b).

In Illinois adults appear in late July:

T. nigrescens is a widespread eastern species, extending from Georgia to Massachusetts and west to Minnesota and Louisiana (Fig. 235). This species has been collected only twice in Illinois.

Illinois Records.-Cook Countw; Willow Springs; Vermilion County; Forest

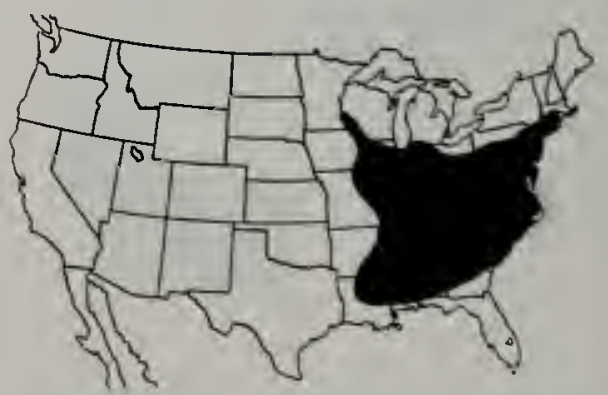

Fig. 235.-Distribution of Tabanus nigrescens in North America. 
Glen Forest Preserve (5 miles SE Westville).

\section{Tabanus nigripes Wiedemann}

Tabanus nigripes Wiedemann (1821:25). Type-locality: Georgia, Savannah. Tabanus coffeatus Macquart (1847:39). Type-locality: Pennsylvania, Philadelphia.

Small to moderate size $(12 \mathrm{~mm})$; blackish brown; subcallus thinly pollinose or partly denuded; eyes bare; thorax does not contrast strongly with abdomen; wings hyaline, occasionally with traces of spots and yellow costal cell; first posterior cell slightly or not at all narrowed at margin; bifurcation of third longitudinal vein without brown spot; tibiae unicolorous although fore tibiae may be slightly paler at base; abdomen with median row of pale triangles, tergites with narrow pale bands on hind margins (Fig. 181). Male eye facets distinctly differentiated; frontal triangle prominent, denuded; eyes bare.

Larvae (Fig. 195) have been found in acidic sphagnum bogs and boglike areas (Teskey 1969) and at the margin of a small pond in a mixed pinehardwood region (Tidwell 1973).

T. nigripes is a widespread central and eastern species, extending from southern Florida to New Hampshire and west to Minnesota and the panhandle of Texas (Fig. 236). This species has been collected only once in lllinois.

Illinois Records.-McHenry County, Algonquin.

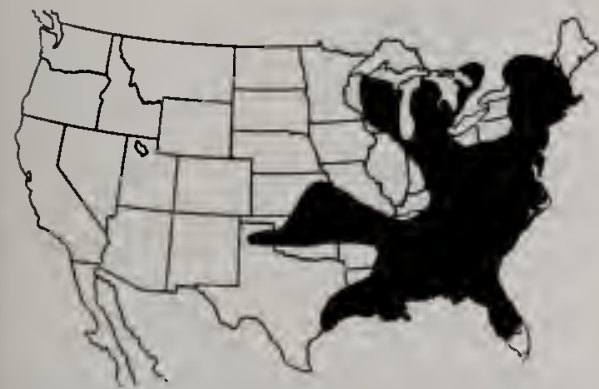

Fig. 236.-Distribution of Tabanus nigripes in North America.

\section{Tabanus novaescotiae Macquart}

Tabanus novae-scotiae Macquart (1847:

40). Type-locality: Nova Scotia.

Tabanus actaeon Osten Sacken (1876:

443). Type-locality: Massachusetts (lectotype).

Fairly large size $(20 \mathrm{~mm})$; reddish brown with thorax sometimes fuscous; eyes bare; thorax does not strongly contrast with abdomen; wing hyaline or faintly tinged with yellow, especially in costal cell; bifurcation of third longitudinal vein without brown spot; basal half of fore tibia yellowish; abdomen with median dark longitudinal band, which may be broad and distinct or nearly obsolete, and median row of pale triangles (Fig. 180). Male eye facets distinctly differentiated; eyes bare.

For many years this species went under the name Tabanus actaeon, and much of the older literature is under this name.

Larvae (Fig. 207) have been found in sphagnum moss (Teskey \& Burger 1976).

In Illinois adults appear in early September.

T. novaescotiae is a northeastern species, extending from the mountains

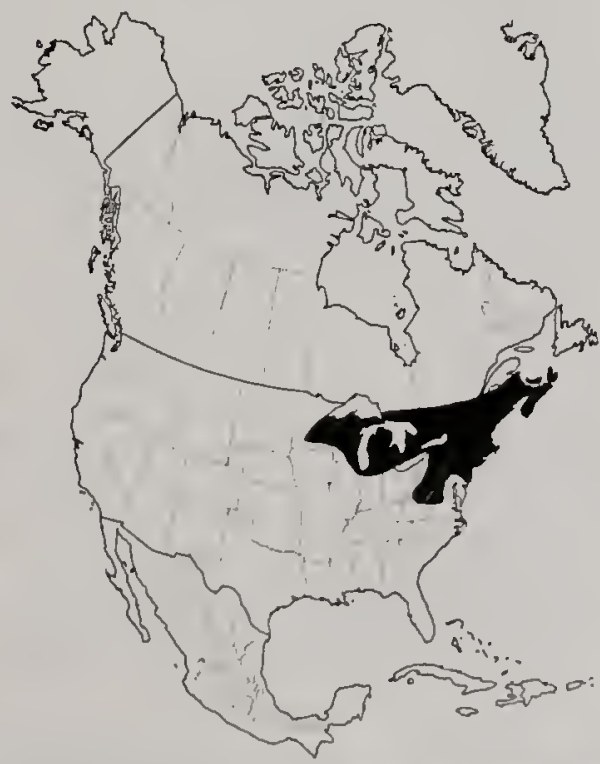

Fig. 237.-Distribution of Tabanus novaescotlae in North America. 
of Virginia and West Virginia to Cape Breton, Nova Scotia and west to Minnesota (Fig. 237). This species has been collected only once in Illinois.

Illinois Records.-Lake County, 2 miles NW Fox Lake.

\section{Tabanus orbicallus Philip}

Tabanus orbicallus Philip (1936a:157).

Type-locality: Kansas, Gove County.

Moderate size (14 mm); grayish; eye hair short, sometimes indistinct; frons broad, widened above; legs rather uniformly yellow; wings, including costal cell, hyaline; median line of abdomen with dark band, on which are poorly indicated pale triangles, yellowbrown area on each side of median band. Male eyes densely pilose; upper eye facets only slightly enlarged; abdomen much like that of female, but yellow-brown area less extensive.

The larva and biology of this species are unknown.

T. orbicallus is a west-central species, extending from western 1 llinois to South Dakota and Kansas (Fig. 238) with a disjunct record of a specimen from Indiana.

Illinois Records.-Henderson County, Big River State Park (4 miles S Keithsburg).

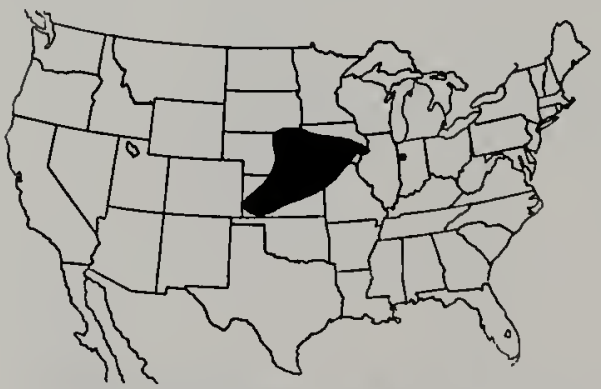

Fig. 238.-Distribution of Tabanus orbicallus in North America.

\section{Tabanus pallidescens Philip}

Tabanus pallidescens Philip (1936b:150).

Type-locality: Mississippi, Blue Mountain.

Moderate size (14 nmm); yellowish; frons very narrow, widened above; antennae yellow, annulate portion some- times a little darker, basal plate broad; palpi white or pale yellow; beard, pleura white haired; legs uniformly yellow; hind femora sometimes with darker shadows; median stripe of abdomen with series of contiguous triangles (Fig. 167). Male readily associated with female; basal plate narrower than in female; upper eye facets much enlarged, occupying two-thirds of eye area, sharply set off from small lower facets.

The larvae (as in fulvulus, Fig. 196) have been taken from well drained leaf covered soils and from ruts in an old logging road in a mixed pinehardwood forest in Louisiana (Tidwell \& Tidwell 1973).

In Illinois adults appear in early June and have been collected until early August.

T. pallidescens is a southeastern species. extending from northern Florida to southern New Jersey and west to Kansas and eastern Texas (Fig. 239). This species has been collected infrequently in the southern half of lllinois (Fig. 239).

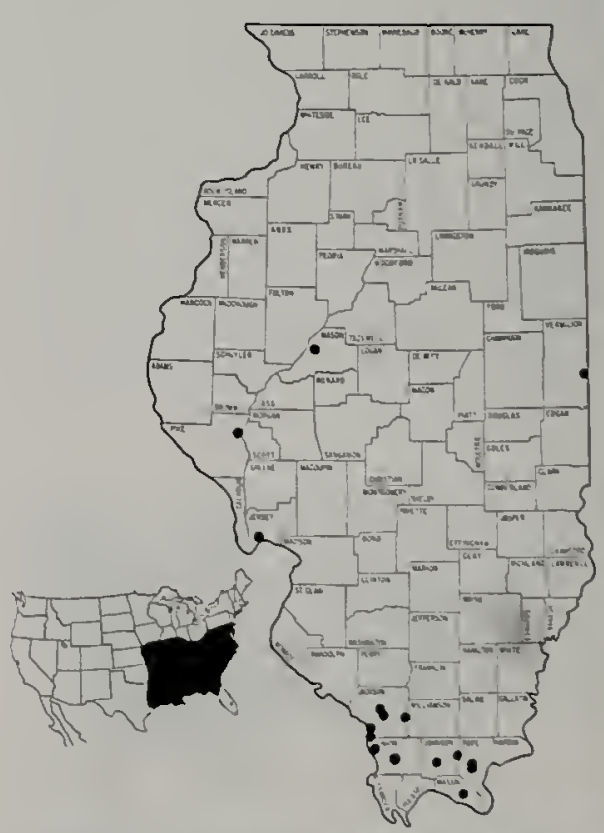

Fig. 239.-Distribution of Tabanus pallidescens in Illinois and North America. 


\section{Tabanus petiolatus Hine}

Tabanus petiolatus Hine (1917:270). Typelocality: Louisiana, Lecompte. Tabanus yulenus Philip (1950b:243).

Type-locality: Louisiana, Triumph.

Moderate size (I6 mm); brownish; frons very narrow, slightly widened above; first posterior cell usually petiolate, sometimes closed or, rarely, narrowly open; fore tibiae bicolored; hind tibiae pale yellow, slightly darkened at extreme apex; abdomen with conspicuous row of pale triangles, which usually cross each segment; on tergite 2 pale triangle expanded anteriorly, joins pale spot on tergite 1 to form hourglass shaped marking (Fig. 182). Male similar to female, but first posterior cell narrowly open; upper eye facets enlarged, line of demarcation distinct.

Larvae have been collected in leaf mold on the banks of a stream and in moss (Teskey 1969).

In lllinois adults appear in late August.

T. petiolatus is a southeastern species, extending from southern Florida to New Jersey and west to southern Illinois and eastern Texas (Fig. 240). This species has been collected only once in Illinois.

Illinois Records.-Johnson County, Little Black Slough Nature Preserve (4 miles SW Vienna).

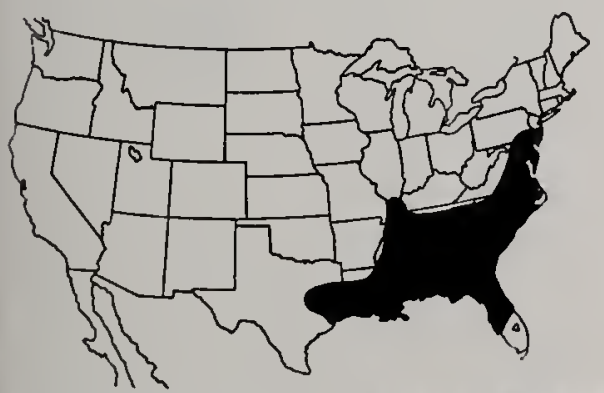

Fig. 240.-Distribution of Tabanus petiolatus in North America.

\section{Tabanus proximus Walker}

Tabanus proximus Walker (1848:147). Type-locality: United States, St. Louis.
Tabanus benedictus Whitney (1904:206).

Type-locality: Missouri, Pike County.

Large size (24 mm); blackish brown with whitish bloom on unicolorous abdomen; frons very narrow, slightly widened above; face, cheeks gray pollinose; antennae orange; palpi dark brown; wing with yellowish tint, costal cell much darker yellow, bifurcation and crossveins with dark spots; first posterior cell narrowly open or closed. Male similar to female; first posterior cell open; upper eye facets enlarged with line of demarcation distinct; small facets extend in band around margin of eye to vertex.

Larvae (Fig. 200) have been collected most often terrestrially in the moist floodplain soils of large rivers (Tidwell 1973) or from the margin of a slough (Jones \& Bradley 1924). Schwardt (1936) found egg masses on tree leaves over a moist pasture and at the border of a small swamp.

In Illinois adults appear in mid-July and have been collected until early September.

$T$. proximus is a central and southern species, extending from the panhan-

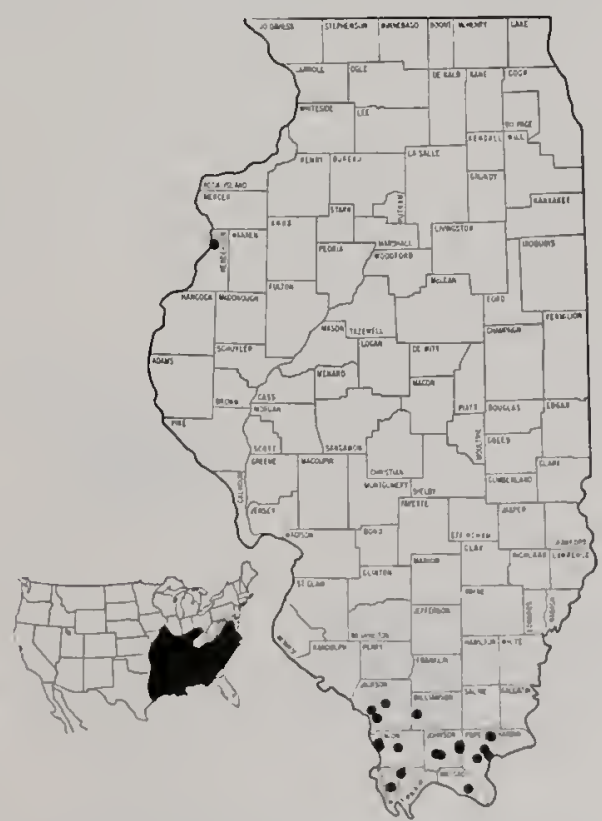

Fig. 241.-Distribution of Tabanus proxlmus in Illinois and North America. 
dle of Florida to Maryland and west to Illinois and eastern Texas (Fig. 241). In Illinois this species has been collected from the western and southern parts of the state (Fig. 241).

\section{Tabanus pumilus Macquart}

Tabanus pumilus Macquart (1838:150).

Type-locality: Carolina.

Small size $(9.5 \mathrm{~mm})$; dark brown to grayish black; median callus subquadrate; second palpal segment rather slender, apex not sharply pointed; frons somewhat widened above; eyes bare; wing hyaline; thorax does not contrast strongly with abdomen, abdomen with row of faint median triangles, roundish sublateral spots (Fig. 174). Male eye facets distinctly differentiated; occipital tubercle conspicuous; eyes bare.

Larvae (Fig. 191) have been collected from saturated, highly or totally organic habitats in bogs and swamps and along streams (Pechuman 1972; Teskey 1969; Tidwell 1973).

In Illinois adults appear in mid-May and have been collected until mid-July.

T. pumilus is an eastern and southern species, extending from central Florida to Maine and west to Iowa and

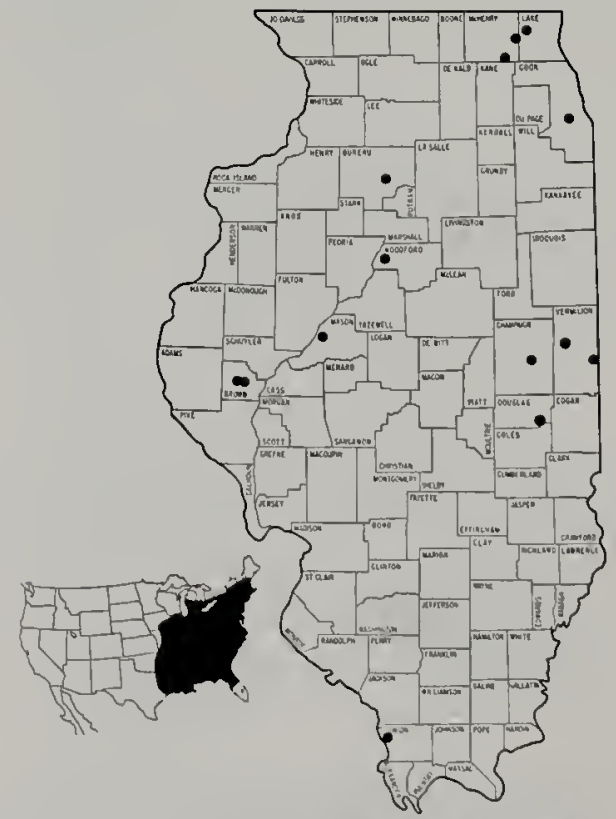

Fig. 242.-Distribution of Tabanus pumllus in Illinois and North America. eastern Texas (Fig. 242). This species is widespread throughout lllinois (Fig. 242).

Tabanus quinquevittatus Wiedemann

Tabanus quinquevittatus Wiedemann (1821:34). Type-locality: Georgia, Savannah.

Tabanus costalis Wiedemann (1828:173). Type-locality: Kentucky:

Tabanus vicarius Walker (in part) (1848:187). Type-locality: North America.

Tabanus manifestus Walker (1850:41). Type-locality: unknown.

Tabanus baltimorensis Macquart (1855:54). Type-locality: Maryland, Baltimore.

Moderate size $(12.5 \mathrm{~mm})$; yellowish; frons with sides essentially parallel; pollen on head yellow; palpi yellow; annulate portion of third antennal segment usually longer than basal portion; eyes bare, in life with single purple band; thorax bright yellow pollinose; prescutal lobe concolorous with rest of mesonotum; wing hyaline with dark yellow costal cell; abdomen with yellow median stripe bordered with black. lateral margins usually yellowish (Fig. 164). Male eye facets distinctly differentiated; eyes bare.

This species is referred to in much of the earlier literature as $T$. costalis and less extensively as $T$. incarius. It can be distinguished from related species by the yellowish color, which includes the palpi and pleurae, and by the deep yellow tint of the costal cell.

Schwardt (1936) obtained numerous egg masses in the laboratory from what he called Tabamus costalis Wiedemann. The egg masses were of two kinds. probably indicating a difference in egg mass form of two species, since his reared specimens were a mixture of $T$. mularis and $T$. quinquezittatus. He noted that the larvae were not cannibalistic, as were those of other species with which he was working, and stiggested that this was part of the reason the adults were so numerous. Presumably his comments apply to both species.

Larvae (Fig. 213), unlike those of most species of Tabanidae, are usually 
tound in relatively dry situations. Moist, but not wet, pastures and hayfields seem to be preferred, but larvae must have considerable tolerance to variations in moisture, since they have been collected in dry, cultivated fields and in mud along the margins of brooks (Pechuman 1972; Teskey 1969). The large populations of this species probably result from this ability to breed in diverse situations.

In Illinois adults appear at the first of July and have been collected until early September.

T. quinquevittatus is a widespread central and eastern species, extending from the southern tip of Florida to southern Quebec and west to Colorado (Fig. 243). This species is widespread throughout all of Illinois (Fig. 243).

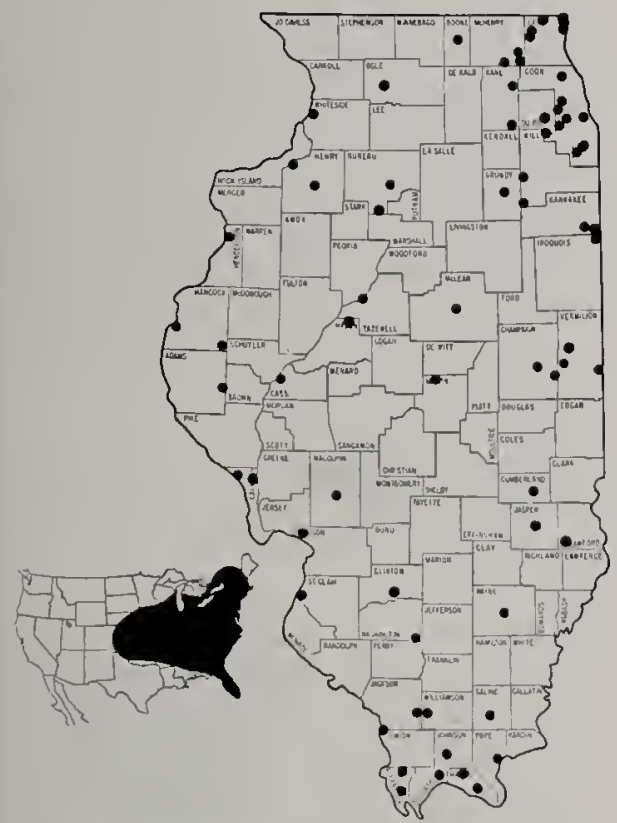

Fig. 243.-Distribution of Tabanus quinquevittatus in Illinois and North America.

Tabanus reinwardtii Wiedemann

Tabanus reinwardiii Wiedemann (1828: 130). Type-locality: Pennsylvania.

Tabanus erythrotelus Walker (1850:25).

Type-locality: North America.

Moderate size (17 mm); grayish black; basal callus large and shiming; frons broad and essentially parallel sided; eyes bare or with short, scattered hairs; thorax does not strongly contrast with abdomen; wing spotted with brown; bifurcation of third longitudinal vein with brown spot; abdomen with gray median triangles, larger pale sublateral spots (Fig. 173). Male eye facets somewhat differentiated, but line of demarcation not distinct; eyes hairy.

Larvae (Fig. 205) are found in mud along streams and ponds, usually in situations where the water is cool and the area shaded (Pechuman 1972; Teskey 1969; Tidwell 1973).

In Illinois adults appear in early July and have been collected until mid-August.

T. reinwardtii is a northern species, extending from northern Georgia to southern Quebec and west to Montana and Alberta (Fig. 244) with a disjunct population on Cape Breton, Nova Scotia. In Illinois this species has been collected widely over the northern half of the state (Fig. 244).

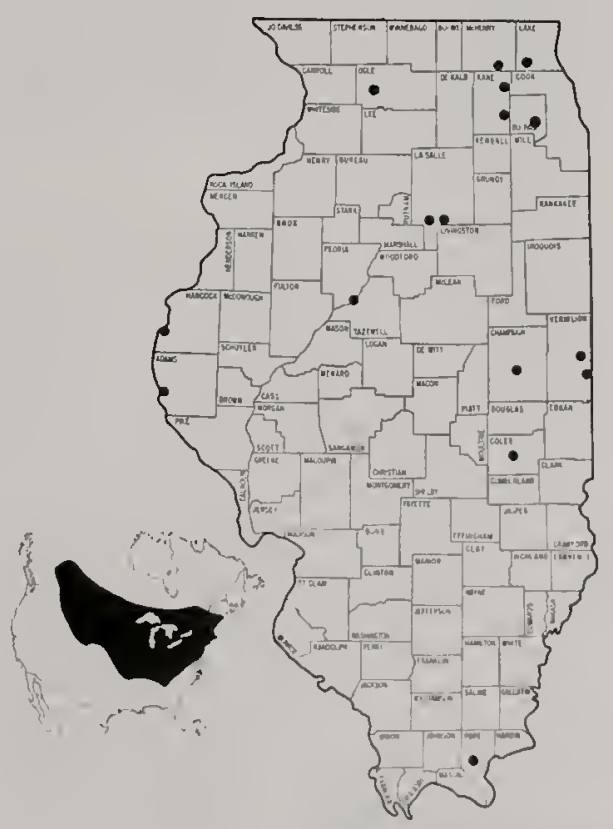

Fig. 244.-Distribution of Tabanus reinwardtli in Illinois and North America.

Tabanus sackeni Fairchild

Tabanus sackeni Fairchild (1934:141). Type-locality: Kentucky, Cumberland Gap. 
Moderate size (13.5 mm); brownish; frons narrow, widened above; palpi white; third antennal segment very slender; eyes bare; wing hyaline; abdomen with pale median line of contiguous triangles and pale sublateral spots, which rarely reach hind margins of tergites (Fig. 168). Male eye facets distinctly differentiated; pale sublateral spots often reach hind margins of tergites; eyes bare.

This species is crepuscular and probably nocturnal as well; many individuals of both sexes have been collected at light. Nothing is known of its biology.

Larvae (Fig. 198) have been collected $10-15 \mathrm{~cm}$ deep in well drained soil on a hillside in a hardwood forest in Arkansas (Goodwin 1976b).

In Illinois adults appear in late June and have been collected until late September.

T. sackeni is a northeastern species, extending from Georgia to New Hampshire and west to Kansas and Arkansas (Fig. 245). This species has been collected in southern Illinois and in a band across north-central Illinois (Fig. 245).

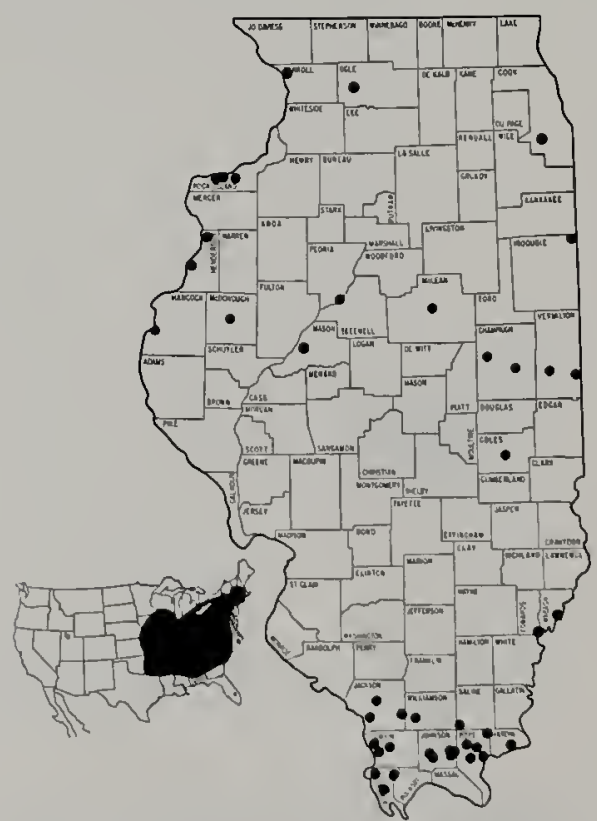

Fig. 245.-Distribution of Tabanus sackenl in Illinois and North America.
Tabanus sagax Osten Sacken

Tabanus sagax Osten Sacken (1876:452).

Type-locality: Illinois (lectotype).

Atylotus baal Townsend (1895:58). Type-

locality: Virginia, Dixie Landing.

Tabanus dawsoni Philip (1931:105). Type-

locality: Minnesota, Itasca Park.

Moderate size $(14 \mathrm{~mm})$; orange brown; frons parallel sided, quite broad; third antennal segment variable but usually slender, dark orange with annuli black; second palpal segment swollen; eyes bare; wing hyaline; abdomen with median line of contiguous triangles, rather indistinct sublateral spots. Male eye facets distinctly differentiated; eyes bare.

This species is rather uncommon throughout its range, and it may be a crepuscular species like $T$. sackeni.

The larvae and biology of this species are unknown.

In Illinois adults appear at the end of July and have been collected until mid-September.

T. sagax is an eastern species, extending from North Carolina to Massachusetts and west to Minnesota and Missouri (Fig. 246). This species has only been collected three times in Illinois from the northern part of the state.

Illinois Records.-Carroll County: Savanna; Lake County, Fox Lake; McHenry County, Algonquin.

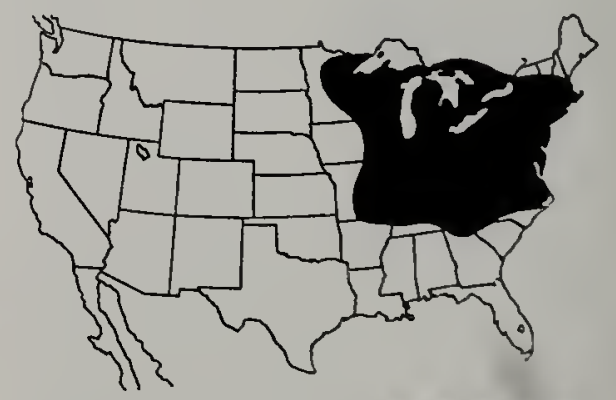

Fig. 246.-Distribution of Tabanus sagax in North America.

\section{Tabanus similis Macquart}

Tabanus similis Macquart (1850:335).

Type-locality: unknown (stated by Macquart to be Tasmania). 
Tabanus scutellaris Walker (1850:27). Type-locality: North America.

Moderate size $(13 \mathrm{~mm})$; brownish to almost black; frons rather broad, widened above; median callus somewhat broadened; eyes bare; annulate portion of third antennal segment usually shorter than basal portion; scutellum reddish brown at tip; wing hyaline; prescutal lobe usually paler than mesonotum; hind femora reddish; abdomen with pale median stripe and sublateral stripes (Fig. 162). Male eye facets differentiated, but size difference small, line of demarcation often indinstinct; general color usually brownish; eyes normally bare, sometimes with few scattered hairs.

Larvae (Fig. 209) have been found in a variety of semiaquatic habitats along streams and ponds and at the edges of marshes and bogs. They are also found in damp sod and relatively dry agricultural land; this terrestrial environment may be this species' more common habitat (Pechuman 1972).

In Illinois adults appear in mid-May and have been collected until midAugust.

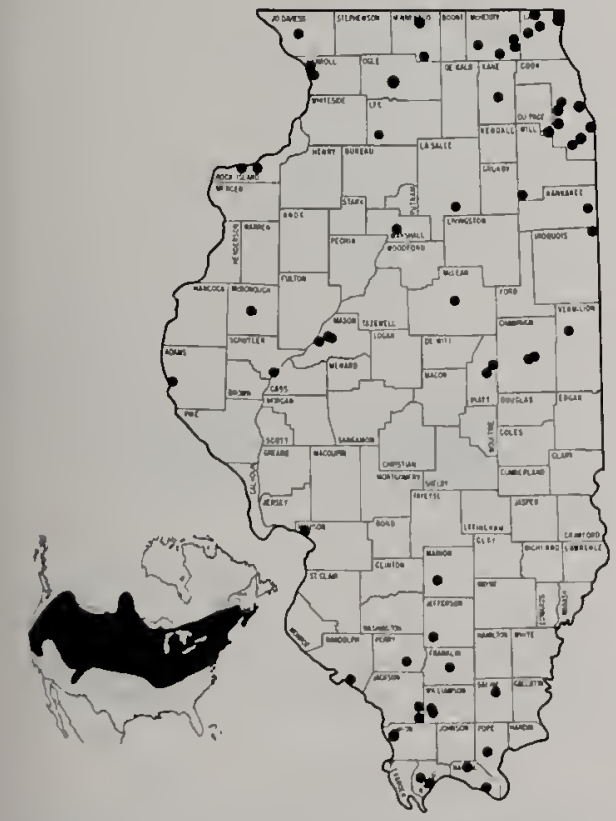

Fig. 247.-Distribution of Tabanus similis in illinois and North America.
T. similis is a widespread species, extending from New Jersey to Nova Scotia and west to British Columbia and California (Fig. 247). In Illinois this species is found throughout the state (Fig. 247).

\section{Tabanus sparus sparus Whitney}

Tabanus sparus sparus Whitney (1879:38).

Type-locality: New Hampshire, Milford.

Small size (10 mm); grayish black; median callus very narrow; second palpal segment swollen at base and sharply pointed; frons narrow, widened above; eyes bare, unicolorous in life; thorax does not strongly contrast with abdomen; wing hyaline; abdomen with row of small median triangles and oval sublateral spots, which often reach hind margins of segments (Fig. 175). Male eye facets distinctly differentiated; occipital tubercle inconspicuous, usually laterally compressed; eyes bare.

Larvae (Fig. 214) have been collected from cranberry bogs and along the boggy margins of streams (Teskey 1969).

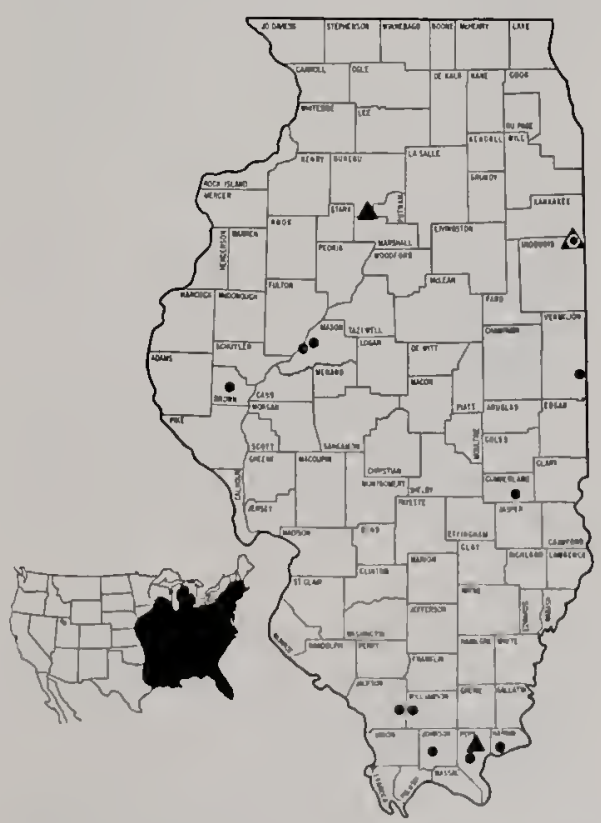

Fig. 248.-Distribution of Tabanus sparus sparus (triangles) and T. sparus milleri (circles) in Illinois and North America. 
In Illinois adults appear in mid-June and have been collected until late July.

$T$. sparus (including the subspecies sparus and milleri) is a widespread eastern species, extending from the tip of Florida to New Hampshire and west to Wisconsin, Kansas, and eastern Texas (Fig. 248). This subspecies has been collected only twice in Illinois. However, the record from Pope County is doubtful, as it is based on a dried specimen on which no eye bands were evident when it was relaxed.

Illinois Records.--Iroquois County, Iroquois County Conservation Area (4 miles NE Beaverville); Pope County, Lusk Creek.

\section{Tabanus sparus milleri Whitney}

Tabanus sparus milleri Whitney (I914:

344). Type-locality: Florida.

No characters have been found to separate dried specimens of this subspecies from T. sparus sparus. However, living specimens and dried specimens which have been moistened have a diagonal purple band on the eye, whereas in T. sparus sparus the eye has no band. The similar-appearing $T$. pumilus has two diagonal bands across the eye in life.

The larvae have been collected in matted roots of grasses and in muck at the edge of a pond (Hays \& Tidwell I967).

In Illinois adults appear in early June and have been collected until late July.

The Nearctic distribution of this subspecies is included within the distribution of T. sparus (Fig. 248). In Illinois this subspecies has been collected widely in the southern half of the state (Fig. 248).

\section{Tabanus stygius Say}

Tabanus stygius Say (1823:33). Typelocality: Arkansas.

Large species (22 mm); frons brown. rather narrow; palpi dark brown to black; subcallus not denuded; eyes bare; thorax with grayish white pile; wing yellowish with dark spots; costal cell deep yellow; abdomen black. Male eye facets distinctly differentiated; pile of thorax dark brown; third antennal segment dark orange; eyes bare.

The egg masses are laid on aquatic plants, chiefly Sagittaria, growing in shallow water. The larvae (Fig. 199) are found in muddy banks of ponds and streams (Pechuman 1972; Teskey I969: Tidwell 1973), and Wilson (I969) reports finding larvae in a relatively dry forest floor in Louisiana. It often takes 2 years for this species to complete its life cycle.

In Illinois adults appear in early June and have been collected until early August.

$T$. stygius is a widespread eastern species, extending from southern Florida to Maine and west to Colorado and eastern Texas (Fig. 249). Although infrequently collected in Illinois, this species is found throughout the state (Fig. 249).

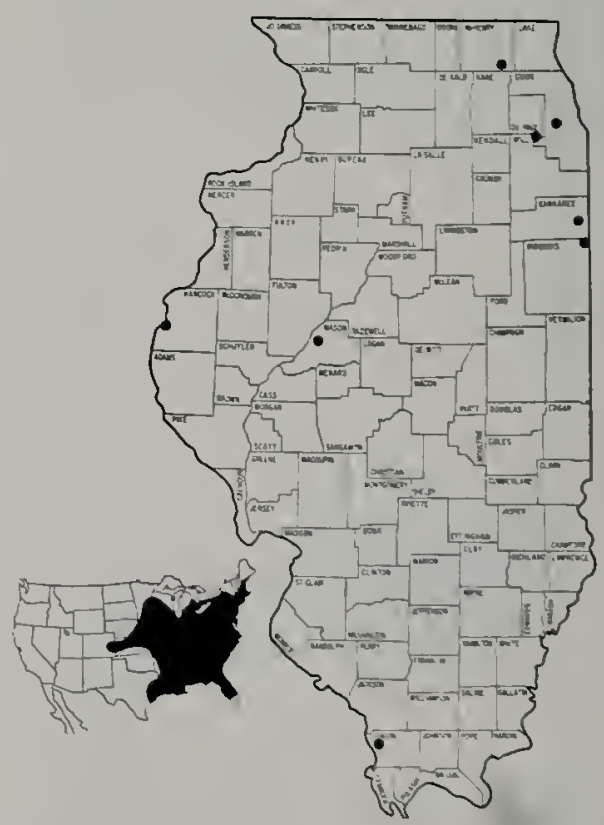

Fig. 249.-Distribution of Tabanus styglus in Illinois and North America.

Tabanus sublongus Stone

Tabanus sublongus Stone (1938:74). Typelocality: Maryland, Plummer Island. 
Moderate size (I3 $\mathrm{mm})$ : dark orange brown; third antennal segment noderately slender; second palpal segment not very swollen basally; frons about four times as high as width at base, parallel sided; eyes bare; wing hyaline: abdomen with median line of contiguous pale triangles, grayish yellow to orange sublateral spots, which usually reach hind nargins of segments (Fig. 169). Male eye facets distinctly differentiated; eyes bare.

The larva and biology of this species are unknown.

In Illinois adults appear at the beginning of July and have been collected until early September.

$T$. sublongus is a central and eastern species, extending from Georgia to New York and west to Kansas and eastern Texas (Fig. 250). Although infrequently collected in Illinois, this species is fairly widespread throughout the state (Fig. 250).

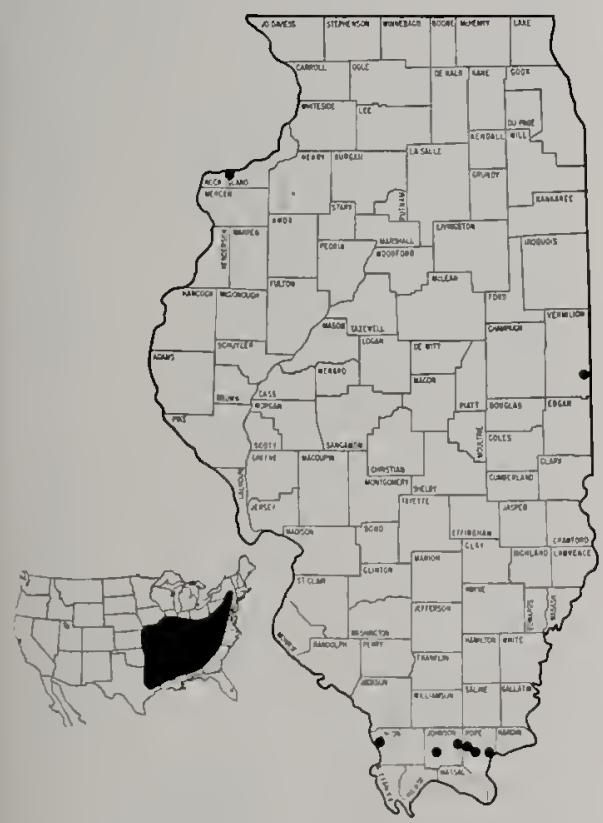

Fig. 250.-Distribution of Tabanus sublongus in Illinois and North America.

\section{Tabanus subniger Coquillett}

Tabanus subniger Coquillett (1906:48). Type-locality: Illinois, Lake Forest.
Tabanus nigricans Johannsen (1935:15), not Wiedemann (1828:157). Misidentification.

Large species (23 $\mathrm{mm}$ ); frons broad, gray, narrowed above, notched at vertex; palpi dark brown to black; subcallus not denuded; eye bare; thorax with grayish white pile; wings pale yellowish with dark spots, costal cell yellow; abdomen black. Male eye facets distinctly differentiated; pile of thorax dark brown; third antennal segment dark brown or black; eyes bare.

This large species superficially resembles $T$. stygius, but is easily distinguished by the characters given in the key.

A single larva of this species was taken from a pond at lthaca, New York. The larva and pupa of this specimen are keyed by Johannsen (1935) to Tabanus nigricans.

In Illinois adults have only been collected from late June to early July.

In spite of its large size and conspicuous appearance, T. subniger is a rarely collected northeastern species, extending from New Jersey to New York and west to Illinois (Fig. 251). This species has been collected twice in northeastern Illinois.

Illinois Records.-Cook County, Stickney; Lake County, Lake Forest.

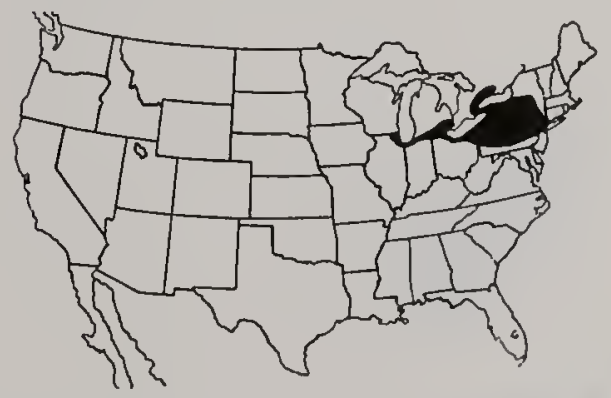

Fig. 251.-Distribution of Tabanus subnlger in North America.

Tabanus subsimilis Bellardi

Tabanus subsimilis Bellardi (1859:66). Type-locality: Mexico.

Tabanus vittiger schwardti Philip (1942:29).

Type-locality: Tennessee, Knoxville. 
Moderate size (14 mm); dark brown to blackish; frons rather broad, usually slightly bowed in center, slightly widened above; eyes bare; wings hyaline; scutellum reddish at tip, sometimes obscurely so; coxae, fore and hind femora blackish; middle femora and occasionally other femora may be somewhat paler toward apex; abdomen with median and sublateral stripes, latter rather irregular, offset between tergites 2 and 3 (Fig. 163). Male with upper eye facets enlarged, distinctly set off from lower small facets, occupying almost three-fourths of total eye area; eyes hairy.

The larvae have been found in mud along the edges of streams and ponds and in seepage areas (Pechuman 1973). Thompson (1975) found the larvae in compost, flower beds, and lawn turf and suggests that this is an adaptive species, which may breed predominately in upland situations.

In Illinois adults appear in early May and have been collected until midOctober. This is the longest period of emergence observed for an lllinois species, suggesting the possibility of more than one generation per year.

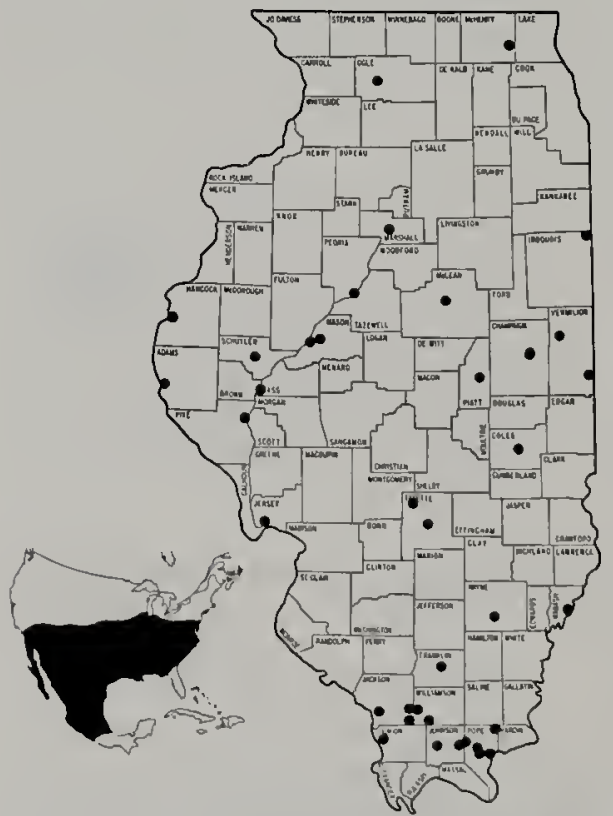

Fig. 252.-Distribution of Tabanus subsimilis in Illinois and North America.
T. subsimilis is a widespread species, extending from southern Mexico to New Jersey and west to southern California (Fig. 252). In Illinois this species is common and widespread (Fig. 252).

\section{Tabanus sulcifrons Macquart}

Tabanus sulcifrons Macquart (1855:53) (as fulcifrons). Type-locality: Maryland, Baltimore.

Tabanus variegatus Fabricius (1805:95).

Type-locality: North America. Name preoccupied (De Geer 1776).

Tabanus tectus Osten Sacken (1876:436).

Type-locality: Pennsylvania, Doubling Gap.

Tabanus exul Osten Sacken (1878:558).

Type-locality: Maryland, Pennsylvania, New Jersey, District of Columbia.

Fairly large size $(20 \mathrm{~mm})$; reddish brown; frons moderately wide, 4.5 times as high as wide (Fig. 187); eyes bare; thorax does not strongly contrast with abdomen; wing somewhat tinted, with dark spots and dark yellow costal cell; bifurcation of third longitudinal vein with brown spot; first posterior cell normally open although often narrowed at margin; fore tibiae pale at base; abdomen with median row of pale rather broad triangles, hind margins of tergites with pale bands that broaden laterally (Fig. 184). Male eye facets distinctly differentiated; eyes bare.

Because of its large size and capacity for blood, this species is occasionally a serious pest. It is most abundant when the other economically important species are gone for the season or on the decline. The adults of both sexes are frequently seen resting on country roads in considerable numbers; when disturbed, the females follow automobiles, even at fairly rapid speeds. They are active until dark and sometimes are found around lights.

The egg masses have been found on small branches of trees well away from water, and larvae (Fig. 211) have been collected in dry and in slightly moist soil as well as at the edges of ponds in saturated mud and plant debris (Pechu- 
man 1972; Teskey 1969; Tidwell 1973; Wilson 1969). There is some evidence that the larvae feed on white grubs (Davis 1919). The normal life cycle is 1 year, but it sometimes requires 2.

In Illinois adults normally appear in June but do not become abundant until July and August; they have been collected until late September.

T. sulcifrons is a southern and eastern species, extending from northern Florida to Rhode Island and west to western Kansas and Texas (Fig. 253). In Illinois this species is collected throughout the state (Fig. 253).

Included with sulcifrons in this study is a form which was collected in some of the southern Illinois counties. It is generally darker, with darker femora and narrower palpi, and the pollen of the mesothorax often has a lavender tinge. The males have enlarged upper eye facets as in sulcifrons, but they take up less of the eye area; the line of demarcation from the small facets is straight rather than sinuate. This form may represent a distinct species, but apparent integrades with the form more generally distributed in lllinois prevent its separation at this time on pure-

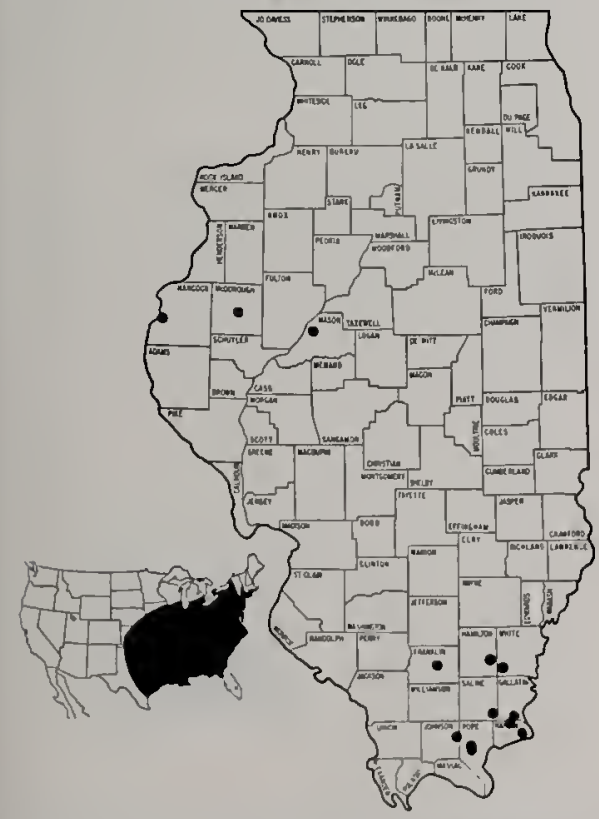

Fig. 253.-Distribution of Tabanus sulclifons in Illinois and North America. ly morphological characters. It is more common in the southern states and generally flies a little later than "typical" sulcifrons, but both may be collected at the same time.

\section{Tabanus superjumentarius Whitney}

\section{Tabanus superjumentarius Whitney}

( I879:37). Type-locality: New Hampshire, Milford.

Moderate size (16 mm); eyes bare; thorax with grayish white pile; wing yellowish, becoming deeper colored anteriorly, especially along veins and in costal cell; fore tibiae uniformly dark; abdomen black with small median white triangles on second to fifth tergites, triangle on second very small or sometimes absent (Fig. 178). Male eye facets distinctly differentiated; thorax with brownish pile; eyes bare.

The larvae (Fig. 204) have been taken from mud and moss along stream banks (Pechuman 1972; Teskey 1969).

In Illinois adults appear at the beginning of June and have been collected until early July.

$T$. superjumentarius is a northeastern species, extending from Alabama to New Hampshire and west to Missouri (Fig. 254). This species has been collected from only one locality in Illinois.

Illinois Records.--Vermilion County, Forest Glen Forest Preserve (5 miles SE Westville).

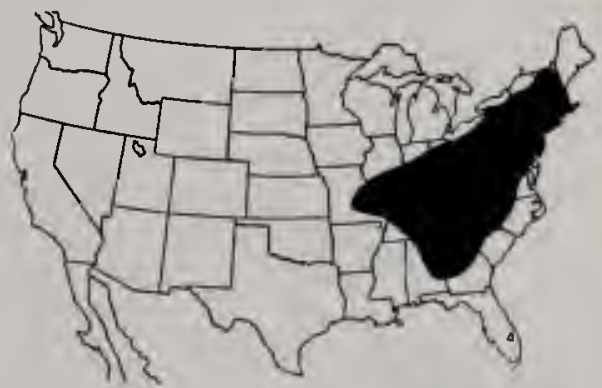

Fig. 254.-Distribution of Tabanus superjumentarius in North America.

\section{Tabanus trimaculatus}

Palisot de Beauvois

Tabanus trimaculatus Palisot de Beauvois (1806:56). Type-locality: Nortl America. 
Tabanus quinquelineatus Macquart (1834:200). Type-locality: Georgia. Tabanus apicalis Walker (1848:176).

Type-locality: unknown. Name preoccupied.

Moderate size $(16 \mathrm{~mm})$; eyes bare; thorax with grayish white pile; wing nearly hyaline except for dark costal cell and dark spots; basal half of fore cibia white; abdomen dark with median white triangles on third, fourth, and fifth segments, occasionally two small sublateral white spots on the second segment (Fig. 170). Male eye facets distinctly differentiated; eyes bare.

The egg masses are deposited on vegetation along the edges of ponds and slow streams, and the larvae (Fig. 206) are found in organic mud and decaying vegetation near water (Pechuman 1972; Tidwell 1973; Goodwin 1973b). Larvae have also been found in rotting logs (Pechuman 1972).

In Illinois adults appear in late May and have been collected until early September.

T. trimaculatus is a widespread species, extending from northern Florida to Rhode Island and west to Nebraska

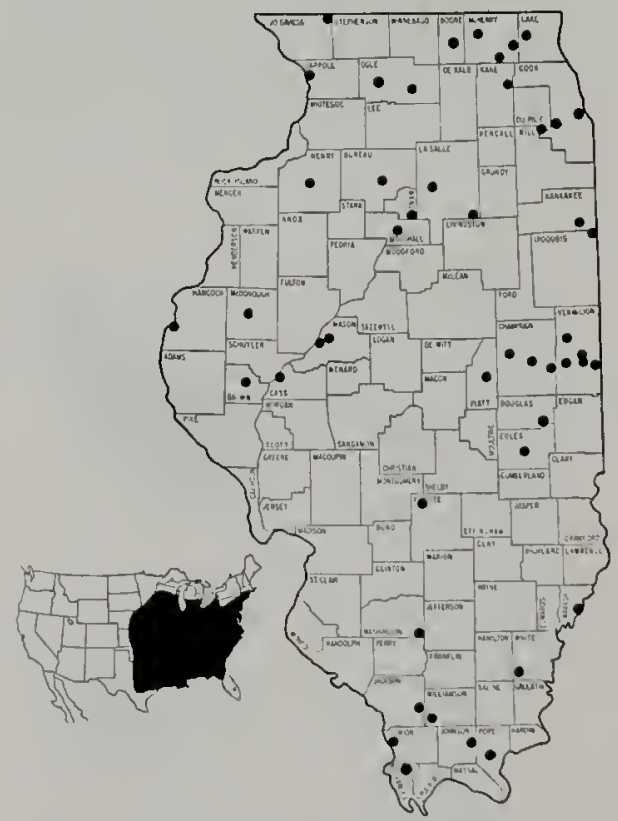

Fig. 255.-Distribution of Tabanus trimaculatus in Illinois and North America. and central Texas (Fig. 255). In Illinois this species is found throughout the state (Fig. 255).

\section{Tabanus turbidus Wiedemann}

Tabanus turbidus Wiedemann (1828:124).

Type-locality: Kentucky.

Large size $(22 \mathrm{~mm})$; brown; frons very narrow, widened above; antennae, palpi, legs reddish brown; wings with brown spot on bifurcation and crossveins, most veins margined with brown: costal cell yellow; first posterior cell wide open; abdomen brown with a row of sometimes indistinct pale triangles (Fig. 185). Male readily associated with female; annulate portion of third antennal segment sometimes slightly darkened; legs a little darker than in female, abdominal spots larger and more conspicuous; upper eve facets enlarged but not sharply set off from smaller facets.

The larva is unknown. The adults are largely crepuscular and nocturnal.

In Illinois adults appear in mid-July and have been collected until late August.

T. turbidus is a southeastern species, extending from central Florida to South Carolina and west to southern Illinois and western Arkansas (Fig. 256). This species has been collected in Illinois only in the south.

Illinois Records.-Alexander Count!: 4 miles ESE McClure; Johnson County; 0.2 mile E Grantsburg: Union County: LaRue-Pine Hills Ecological Area (4 miles N Wolf Lake), Union County Conservation Area (2 miles SE Ware).

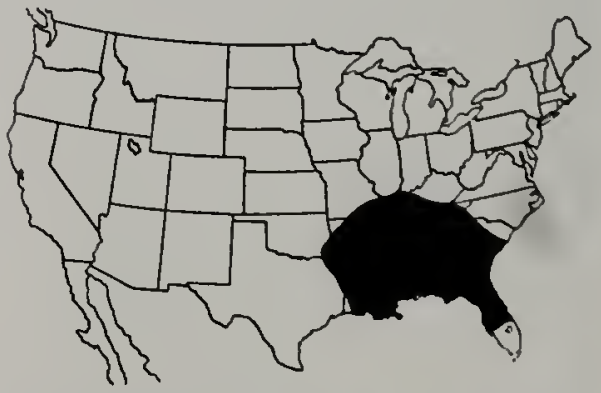

Fig. 256.-Distribution of Tabanus turbidus in North America. 


\section{Tabanus venustus Osten Sacken}

Tabanus venustus Osten Sacken (1876: 444). Type-locality: Texas, Dallas. Moderate size (16 mm); brown; wings variegated with brown areas not confined to bifurcation and crossbands; abdomen with white median triangles, small sublateral spots on tergites 3-6 (Fig. 171). Male easily associated with female by its variegated wings but differs in having a brown thoracic dorsum except for white pollinose scutellum; abdominal pale areas much more extensive than in female, formed by running together of median and sublateral spots to form pale posterior bands on tergites 2-4; upper eye facets somewhat enlarged but not clearly set off from small facets.

Larvae of $T$. venustius have been collected on the banks of streams and spring-fed ponds (Schwardt 1936). Thompson et al. (1978) collected a larva at the margin of a small pond.

In Illinois adults appear in late June and have been collected until early September.

T. venustus is a south-central species,

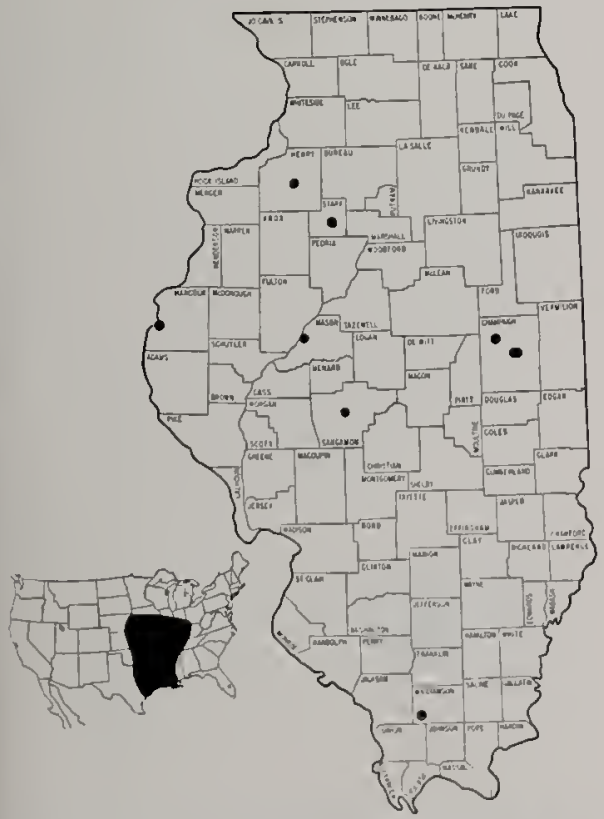

Fig. 257.-Distribution of Tabanus venustus in Illinois and North America. extending from Lourisiana to southwestern Ohio and west to Nebraska and central Texas (Fig. 257). In Illinois this species has been infrequently collected (Fig. 257).

\section{Tabanus vivax Osten Sacken}

Tabanus vivax Osten Sacken (1876:446).

Type-locality: New York, Trenton

Falls.

Tabanus arborealis Stone (1935:14). Typelocality: Vermont, Rutland.

Moderate size (14.5 $\mathrm{mm})$; dark brown, sometimes with reddish cast and sometines nearly black; vertex slightly depressed or flat; frons about 3.5 times as high as wide; last antennal annulus black; first antennal segment not swollen above; sides of subcallus without hairs; eyes bare; thorax does not strongly contrast with abdomen; wing hyaline often with yellowish tinge anteriorly; abdomen witl three rows of pale spots, median triangle on second segment does not reach anterior margin. Male eye facets distinctly differentiated, lower facets curve upward in band separating large facets laterally from eye margin; eyes bare.

This species is not commonly col-

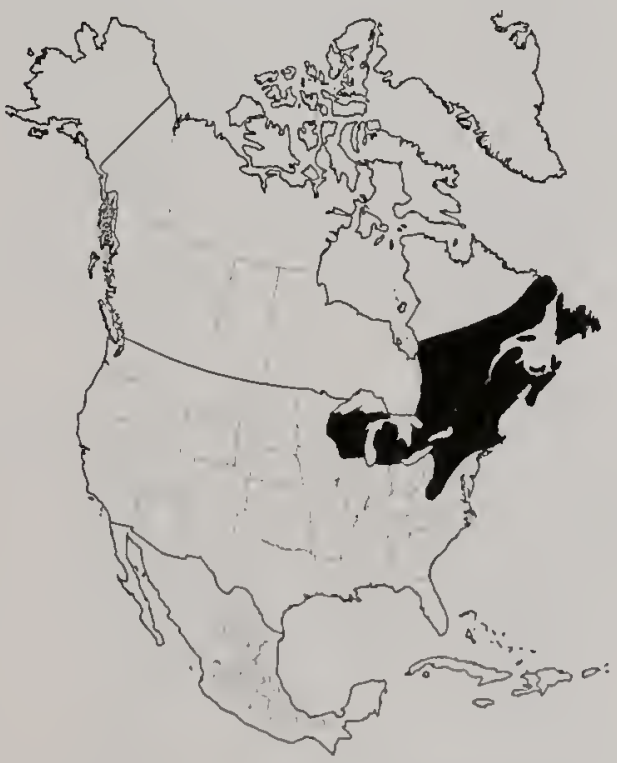

Fig. 258.-Distribution of Tabanus vivax in North America. 
lected. For many years it was confused with what is now called $T$. fairchildi, and most records earlier than 1938 actually refer to fairchildi.

Larvae (as in marginalis, Fig. 193) have been found in pasture sod at the edge of a permanently wet area and in boglike areas bordering streams (Pechuman 1972; Teskey 1969).

T. vivax is a northeastern species, extending from West Virginia to Labrador and west to Wisconsin (Fig. 258). As yet this species has not been collected in Illinois although specimens have been examined from southern Wisconsin.

\section{Tabanus wilsoni Pechuman}

Tabanus wilsoni Pechuman (1962:66).

Type-locality: Arkansas, Arkansas

County, Arkansas River.

Moderate size $(14 \mathrm{~mm})$; brown; frons very narrow, sometimes slightly widened above; first two antennal segments and rather broad basal plate of third segment dark yellow, annulate portion black; palpi white; dorsum of thorax brown, contrasting with gray pollinose, white haired pleurae; wings with faint yellowish tint, darker in costal cell; coxae, fore and hind femora mostly dusky; pale median band of abdomen narrow, widening at apex of each segment; sublateral spots small, roundish, yellow brown. Male similar to female, but basal plate of antennae narrower, pleural hairs with yellowish tint, sublateral abdominal spots more extensive; upper eye facets not greatly

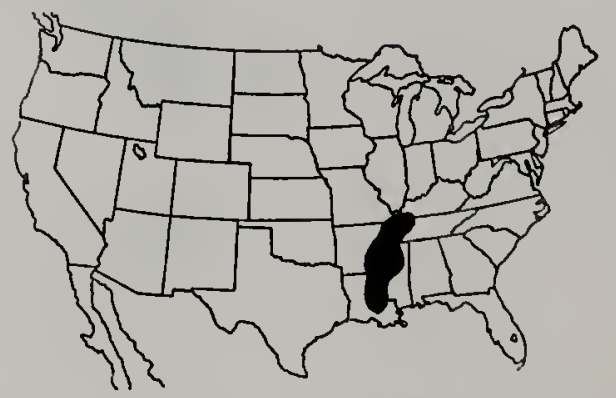

Fig. 259.-Distribution of Tabanus wilsoni in North America. enlarged but line of demarcation distinct.

Larvae (as in fulvulus, Fig. 196) have been found in relatively dry soil in a bottomland hardwood forest in Louisiana (Tidwell \& Tidwell 1973).

T. wilsoni is a south-central species, extending in a narrow band from Louisiana to western Kentucky (Fig. 259). As yet this species has not been collected in Illinois although specimens have been examined from western Kentucky.

\section{Hamatabanus Philip \\ Hamatabanus carolinensis (Macquart)}

Tabanus carolinensis Macquart (1838:149). Type-locality: Carolina.

Tabanus scitus Walker (1848:181). Typelocality: Georgia.

Tabanus hirtioculatus Macquart (1855:53).

Type-locality: Maryland, Baltimore.

Tabanus cerastes Osten Sacken (1876:

462). Type-locality: Kentucky; Bee

Spring.

Large, stout (14 mm); brownish: eyes sparsely pilose; subcallus pollinose; frons higher than wide; third antennal

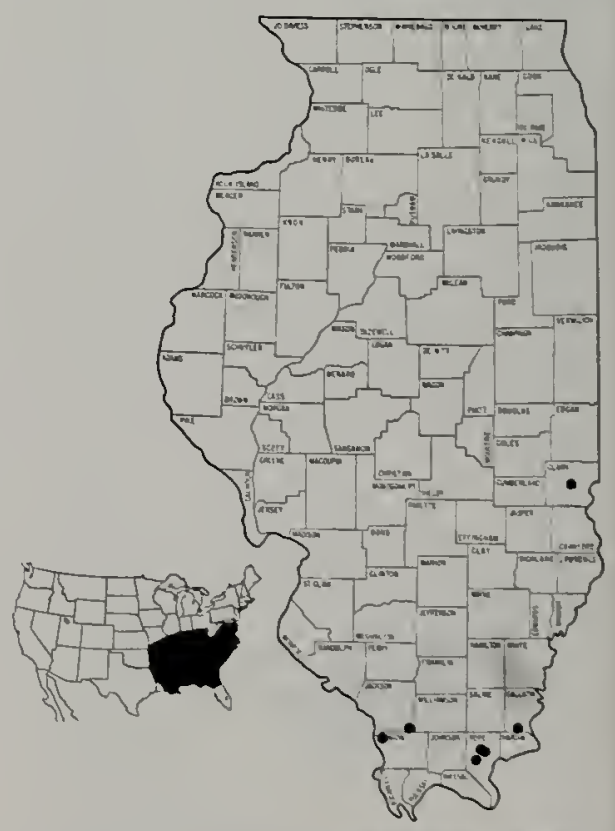

Fig. 260.-Distribution of Hamatabanus carolinensis in Illinois and North America. 
segment with extended dorsal angle (Fig. 30); abdomen with three rows of pale spots; wings hyaline to pale brown; hind tibiae without apical spurs, sublateral ones on second abdominal tergite frequently reaching entirely across segment. Male readily associated with female but eyes more obviously hairy.

The larva is unknown.

In Illinois adults appear at the beginning of June and have been collected until early July.

$H$. carolinensis is a southeastern species, extending from northern Florida to Maryland and west to Missouri and Louisiana (Fig. 260). In Illinois this species is found only in the southern part of the state (Fig. 260).

\section{KEY TO SPECIES OF HYBOMITRA}

\section{Females}

1. Black species with first $\mathbf{3}$ abdominal segments mostly bright orange cincta

Abdomen otherwise marked 2

2. Subcallus denuded, shining.............................

Subcallus pollinose......................................6

3. Subcallus swollen; whole of face below eyes denuded, shining; small species with dark wing markings .. ...hinei

Subcallus normal; face below eyes not shining

4. Abdomen broadly orange brown laterally, median black area constricted on third segment; all crossveins spotted with brown .........................lasiophthalma

Abdomen not broadly orange brown laterally, if paler laterally, median dark area on third segment not constricted....5

5. Eye apparently bare; basal portion of third antennal segment narrow; abdomen brownish, faintly reddish brown laterally with median row of indistinct whitish triangles ..................difficilis

Eye hairy; basal portion of third antennal segment stout lurida

6. Abdomen broadly orange brown laterally; basal plate and usually annulate portion of antennae orange; palpi stout; frons about 5 times as high as width at base, widened above ....epistates Without this combination of characters ....7

7. Bifurcation with distinct spur vein ........ tetrica hirtula

No spur vein at bifurcation ....8

8. Abdomen black with median row of distinct white triangles, no sublateral spots ..sodalis
Abdomen otherwise marked .......................9

9. Second palpal segment slender, scarcely thickened at base .................................. 10

Second palpal segment stout, especially at base ... 12

10. Femora, except bases of hind femora, brown; sides of abdomen reddish brown; second palpal segment extremely slender; third antennal segment practically without dorsal excision ........................................minuscula

Femora usually black, if brown, sides of abdomen without considerable orange brown

11. Prescutal lobe black; hair of palpi uneven astuta

Prescutal lobe pale; hair of palpi short, lying smoothly against segment pechumani

12. Bifurcation with distinct spot; third antennal segment stout illota

Bifurcation without distinct spot: third antennal segment more slender...........13

13. Legs nearly uniformly brownish, rarely femora somewhat darker; third antennal segment very slender; prescutal lobe black .microcephala

Femora black or grayish; third antennal segment not especially slender; prescutal lobe rarely black frontalis

\section{Males}

1. Stiff hairs along midline between eyes difficilis

No stiff hairs along midline between eyes

2. Black species with first 3 abdominal segments mostly bright orange ......cincta

Abdomen otherwise marked .......................3

3. Small dark species with gray, protuberant frontal triangle: genae black. somewhat shining; dark cloud on wing near stigma ............................hinei

Differing in one or more characters from above .................................................4

4. Crossveins and bifurcation with distinct dark spots; abdomen laterally broadly orange .................... lasiophthalma

Wings hyaline, tinted, or with dark spot only at bifurcation

5. Abdomen black, obscurely reddish laterally with no distinct sublateral spots; conspicuous row of white median triangles sodalis

Abdomen otherwise marked ....................6

6. Small species, not over $12 \mathrm{~mm}$, with very slender second palpal segment; sides of abdomen broadly dark orange, but first segment usually completely black; third segment witlı very shallow dorsal excision ...........minuscula

Species usually over $12 \mathrm{~mm}$, but if smaller, second palpal segment stout. dorsal excision distinct

0

. 
7. Bifurcation with distinct spur vein ........ tetrica hirtula

No spur vein at bifurcation ....8

8. Prescutal lobe black.

Prescutal lobe reddish, at least on disc......10

9. Femora brown; second palpal segment stout . microcephala

Femora black; second palpal segment small, slender

10. Abdomen rather broadly orange brown laterally

Abdomen may have some orange brown markings laterally, but such markings cover only small section of segment ....13

11. First abdominal sternite orange, occasionally with small dark area in center; third antennal segment, usually including annuli, reddish epistates

First abdominal sternite almost entirely black or with small orange area sublaterally; at least annulate portion of third antennal segment darkened.

12. Frontal triangle rather flat; base of third antennal segment slender; palpi moderately stout, yellowish brown; wing often dilutely infuscated but without intensification in anterior portion; costal cell dilutely tinted or clear

frontalis

Frontal triangle protuberant; base of third antennal segment rather stout; palpi very stout, grayish brown; anterior portion of wing often infuscated along veins, in basal cells, and at bifurcation; costal cell tinted......lurida

13. Bifurcation with distinct spot; palpi very stout; eye facets rather uniform in size illota

Bifurcation without spot; palpi rather slender; upper eye facets distinctly larger than lower facets .......... pechumani

\section{Larvae}

1. Pubescence restricted to minute indistinct patches on subdorsal or dorsal anterior margin of metathorax and first 2 abdominal segments and posterior dorsal margin of anal segment in addition to usual pubescence encircling anterior of prothorax, and on anal ridges (Fig. 261) ..........microcephala

Pubescence present additionally on at least anterolateral margins of mesoand metathorax and/or dorsolaterally on 3 or more abdominal segments ........2

2. Anterior pubescence on abdominal segnents 1 to 7 conspicuously darker dorsolaterally than elsewhere (Fig. 262, 263)

Darker pubescence, il present, extends over entire dorstum and not restricted to dorsolateral aspects, or anterior pubescence present on fewer abdominal segments (Fig. 264-270) ..................5

3. Respiratory siphon approximately 1.5 times as long as its basal diameter: pubescence encircles anterior of mesoand metathorax (Fig. 263).

Respiratory siphon about equal in length to its basal diameter; pubescence usually does not encircle anterior of mesoand metathorax, either absent dorsally or laterally or from all aspects of these segments (Fig. 262) ............lasiophthalma

4. Body reddish brown; posterior pubescence on preanal segment, if present, usually forms an even band that is narrowly interrupted only dorsally (Fig. 263) epistates

Tw Body normally olive green, though occasionally brown: posterior pubescence on preanal segment usually forms ragged series of small patches. but sometimes absent illota

5. Anterior pubescence present at least dorsolaterally on first 5-7 abdominal segments: posterior pubescence present on, often encircles, preanal segment (Fig. 264-266)

Anterior pubescence present dorsolaterally on fewer than $\mathbf{5}$ abdominal segments: posterior pubescence usually absent from preanal segment, but if present, does not encircle segment (Fig. 267-270)

6. Anterior pubescence encircles thoracic segments; respiratory siphon approximately 1.5 times as long as its basal diameter (Fig. 264) frontalis

Anterior pubescence on meso- and metathorax interrupted dorsally and ventrally; respiratory siphon about twice as long as its basal diameter.

7. Anterior pubescence traverses dorsum of first 4 or 5 abdominal segments, connected dorsolaterally to faint band of pubescence bordering adjacent proleg (Fig. 265) ..........................................hinei

Anterior pubescence traverses dorsum of only first 2 or 3 abdominal segments; proleg pubescence essentially absent, at least a distinct break exists dorsolaterally between anterior pubescence and prolegs (Fig. 266)....minuscula

8. Anal segment and respiratory siphon both distinctly longer than their greatest diameters; anal segnent more or less attenuated posteriorl when fully expanded (Fig. 265) ................ cincta

Either anal segment or respiratorv siphon or both about equal in length to their greatest diameters; anal segment semispherical and slighty swollen (Fig. 2(38-270) 


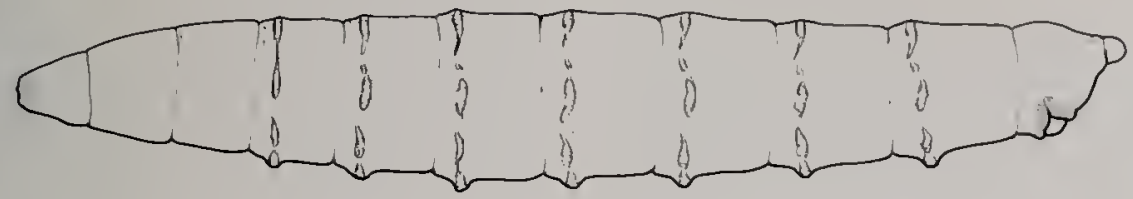

261 microcephala

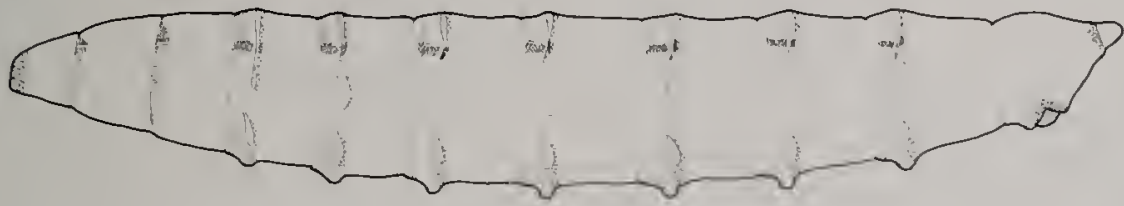

262 lasiophthalma
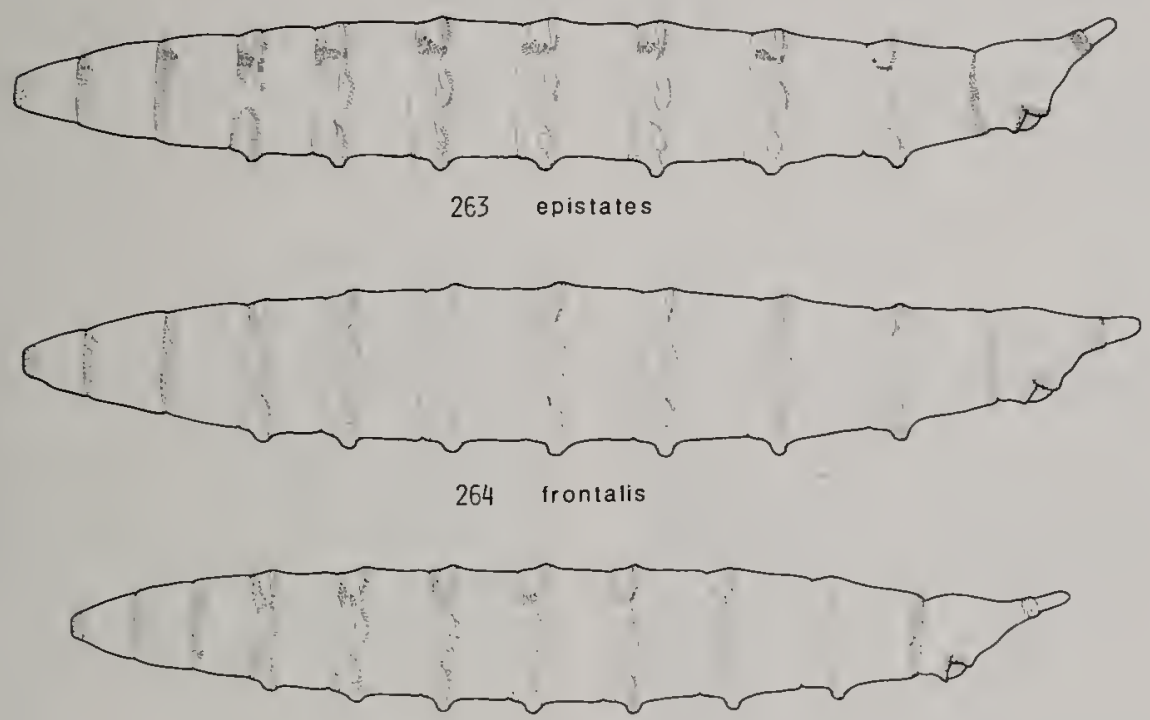

265 hinei
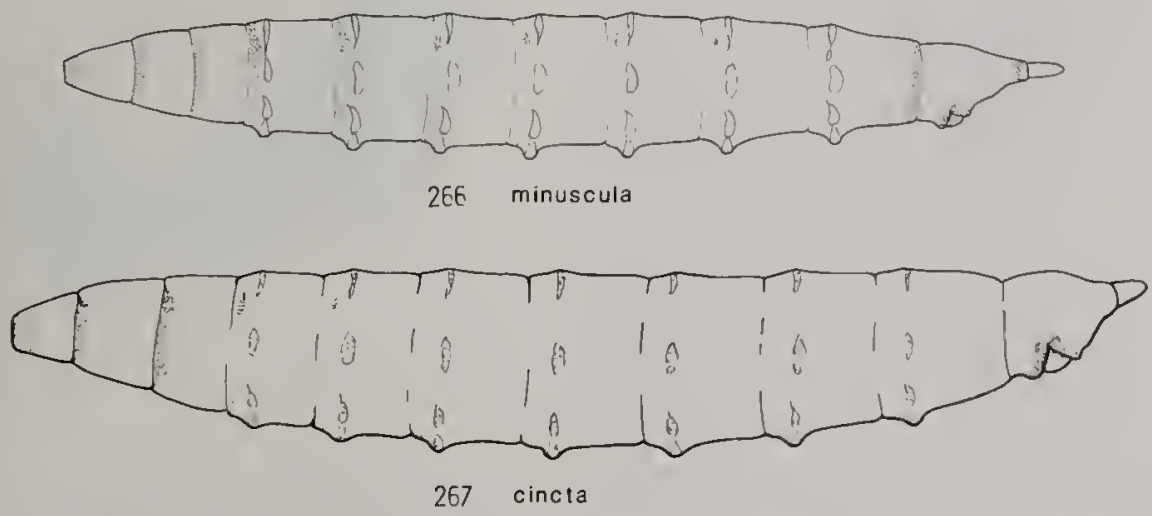

Fig. 261-267.-Larvae. 261. Hybomitra microcephala. 262. H. lasiophthaima. 263. H. epistates. 264. H. frontalis. 265. H. hinel. 266. H. minuscula. 267. H. clncta. 

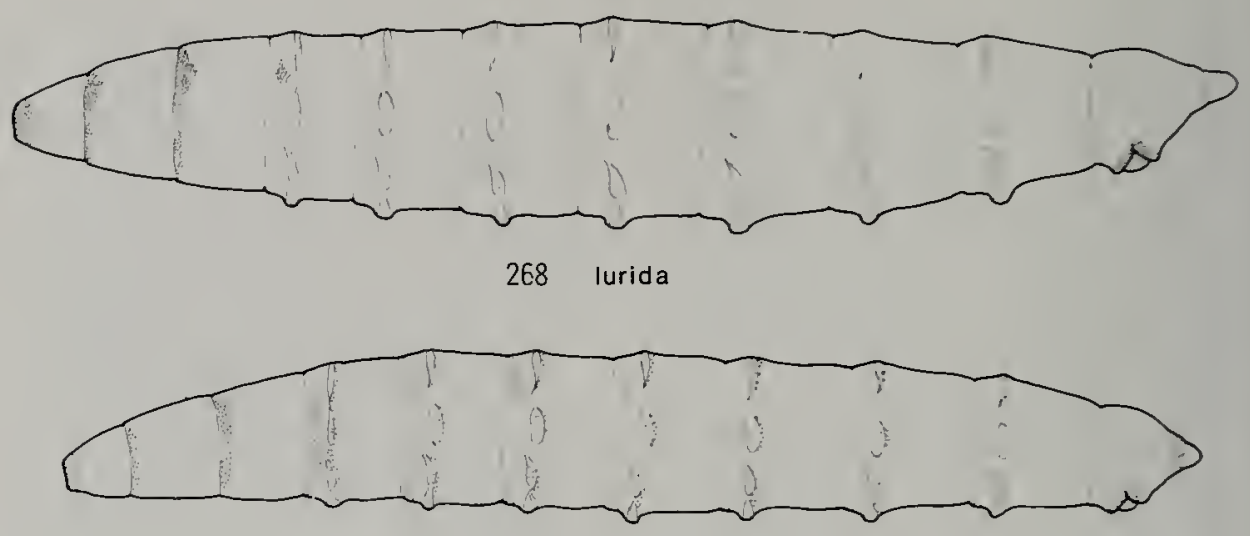

$2 E 3$

pechumani

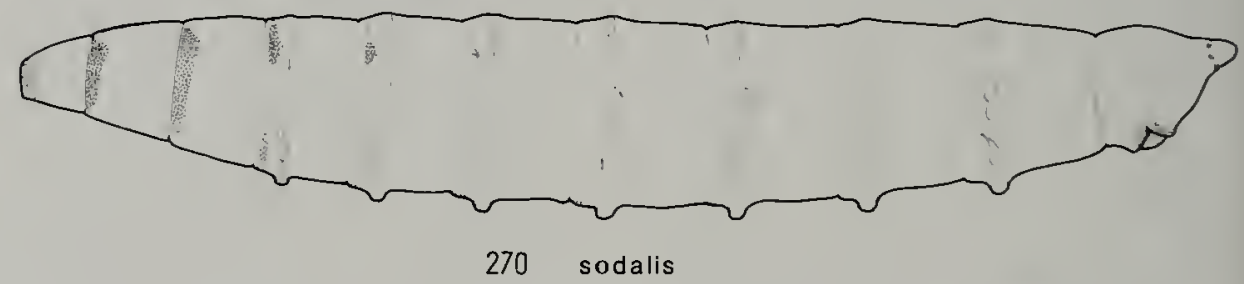

Fig. 268-270.-Lanvae. 268. Hybomitra lurida. 269. H. pechumani. 270. H. sodalis.

9. Posterior pubescence absent from anal segment (Fig. 268); tracheal trunks swollen to about $0.7 \mathrm{~nm}$ wide in preanal segment, abruptly tapered at level of first abdominal segment.......urida

Posterior pubescence present, although often indistinct, on anal segment (Fig. $269,270)$; tracheal trunks slender $(0.4$ $\mathrm{mm}$ wide in preanal segment) and rather gradually tapered anteriorly ....10

10. Pubescence very pale, usually encircling anterior margin of first abdominal segment and posterior margin of anal segment (Fig. 269); living larva light green .......................................... pechumani

Pubescence moderately pigmented, at least on thoracic segments, absent laterally on anterior margin of first abdominal segment, vestigial on posterior margin of anal segment (Fig. 270); living larva pale brown sodalis

\section{Hybomitra astuta (Osten Sacken)}

Tabanus astutus Osten Sacken (1876: 471). Type-locality: New Hampshire, White Mountains.

Moderate size $(14 \mathrm{~mm})$; brownish black; eyes hairy; second palpal segment slender, scarcely thickened at base; palpal hairs long, uneven, semi-erect; subcallus pollinose; abdomen with three rows of grayish triangles; prescutal lobes dark; wings hyaline, costal cell pale yellow. Male eye facets scarcely differentiated; pale abdominal markings with orange cast; eyes hairy:

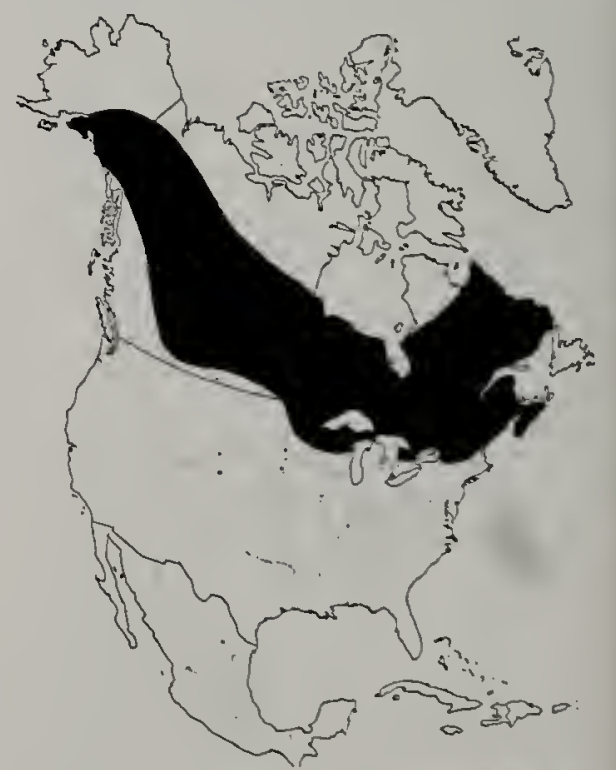

Fig. 271.-Distribution of Hybomitra astuta in North America. 
Moderate size (14 mm); brownish; second palpal segment rather swollen; subcallus pollinose; frons about five times as high as width at base, widened above; basal portion of third antennal segment mostly orange, about twothirds as wide as long; eyes hairy. Male eye facets scarcely differentiated; eyes hairy.

Larvae (Fig. 263) are usually found in wet moss in swamps (Pechuman 1972; Teskey 1969).

In Illinois adults appear in mid-June and have been collected until mid-July.

$H$. epistates is a northern species, extending from Delaware to Nova Scotia and west to Oregon and Alaska (Fig. 274). In Illinois this species is collected only in the northern half of the state (Fig. 274).

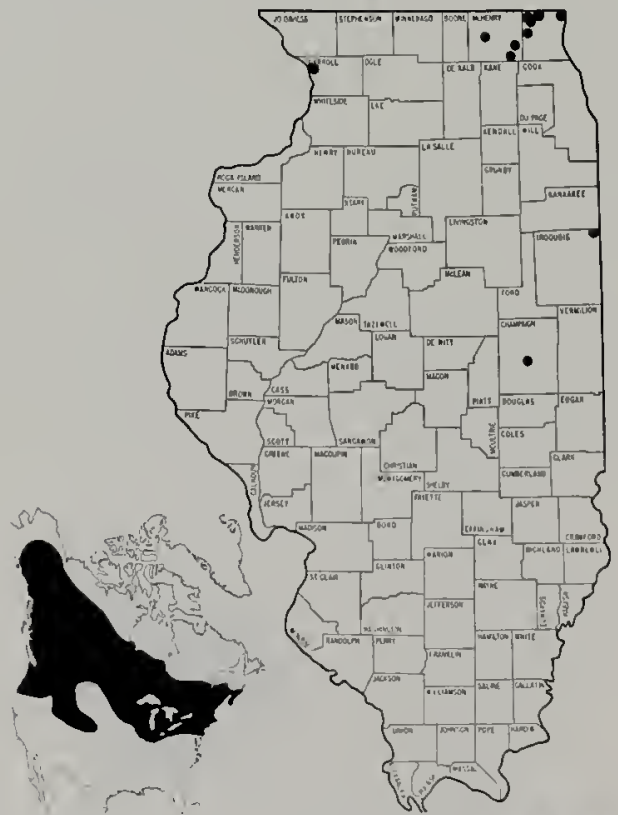

Fig. 274.-Distribution of Hybomitra epistates in Illinois and North America.

\section{Hybomitra frontalis (Walker)}

Tabamus frontalis Walker (1848:172). Type-locality: Nova Scotia, Cape Breton.

Tabanus incisus Walker (1850:26). Typelocality: Nova Scotia.

Tabanus septentrionalis Loew (1858:592).

Type-locality: Labrador.

Tylostypia labradorensis Enderlein (1925:

363). Type-locality: Labrador.
Tabanus canadensis Curran (1927:82). Type-locality: Manitoba, Winnipegosis.

Moderate size (14 mm); blackish brown to yellowish; eyes hairy; subcallus pollinose; second palpal segment stout. especially at base; prescutal lobe rarely black; abdomen with faint grayish or yellowish median triangles, yellowish, reddish, or gray sublateral spots, which may or may not reach hind margins of tergites; wing hyaline, costal cell tinged with yellow; femora black or grayish. Male eye facets slightly differentiated but line of demarcation indistinct; sublateral abdominal spots usually larger, more reddish than in female. sometimes forming broad sublateral band; eyes hairy.

Pechuman (1957) treated this species as two subspecies. Intergrades between the two forms are found frequently. Although McAlpine (196l) has characterized a number of morphs, Pechuman believes them all to belong to a single species.

Larvae (Fig. 264) have been collected from wet moss in swamps (Teskey 1969).

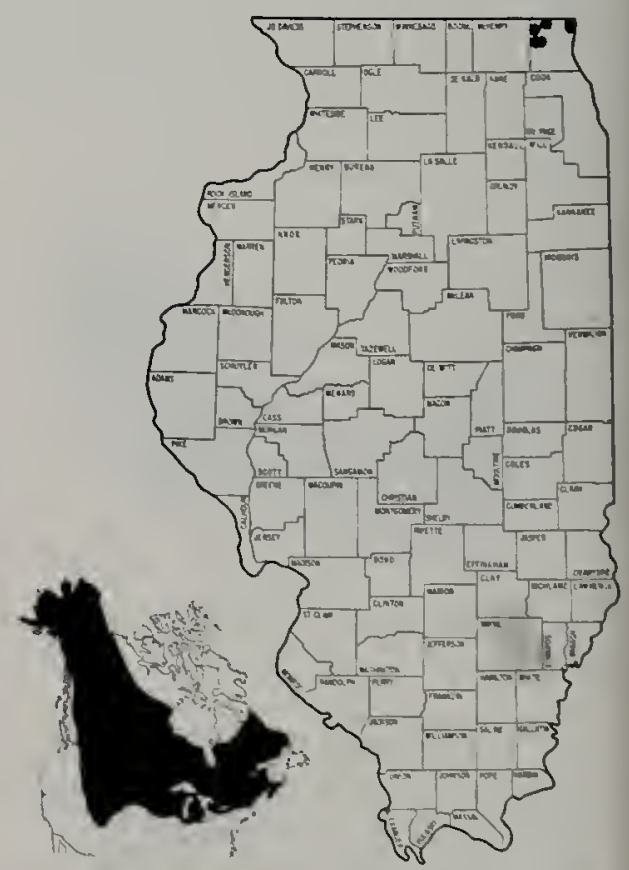

Fig. 275.-Distribution of Hybomitra frontalis in Illinois and North America. 
Hybomitra lasiophthalma (Macquart)

Tabanus lasiophthalmus Macquart (1838: 147). Type-locality: Carolina.

Tabanus punctipennis Macquart (1847:39). Type-locality: Pennsylvania. Philadelphia.

Tabanus notabilis Walker (1848:166). Type-locality: New York and Georgia. Tabanus fretus Stone (1938:154). Typelocality: Connecticut, Lyme.

Tabanus guttiferus Harris (1925:70). Nomen nudum.

Tabanus redactus Walker (1850:66). Typelocality: unknown.

Moderate size $(14 \mathrm{~mm})$; brownish; subcallus denuded, shiny; eyes hairy: basal callus shiny, protuberant: abdomen broadly orange brown laterally; wings hyaline or faintly tinted, with conspicuous dark spots, yellow costal cell. Male eye facets little differentiated: frontal triangle grayish; eyes hairy.

The eggs are laid on various plants over moist ground; the egg mass is small and shining black, resembling a drop of tar on the leaf. Larvae (Fig. 262) are found in moist or wet sod, sphagnum bogs, and marshes (Pechu-

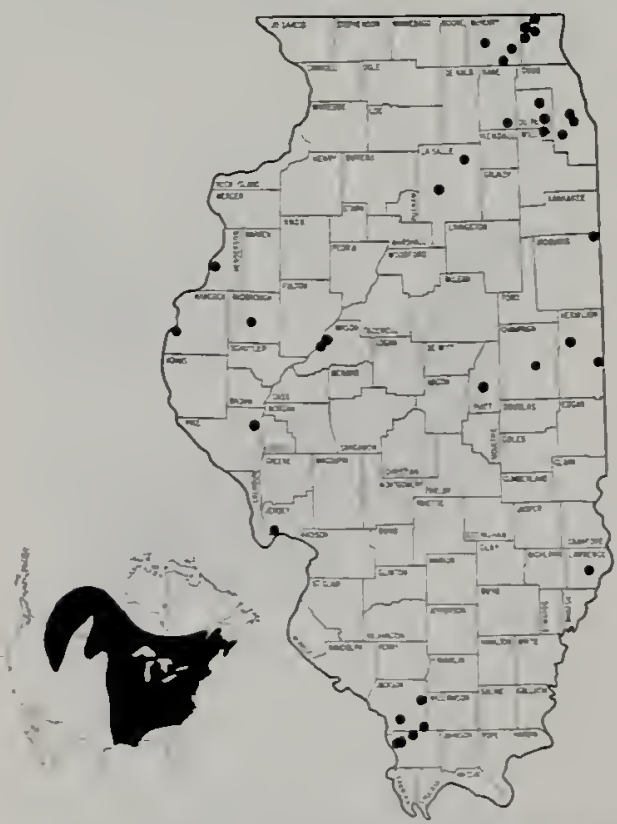

Fig. 278.-Distribution of Hybomitra laslophthalma in Illinois and North America. man 1972; Teskey 1969). Wilson (1969) collected larvae from a relatively dry forest floor.

In Illinois adults appear in mid-April and have been collected until mid-July:

$H$. lasiophthalma is a wide-ranging species. extending from Georgia to southern Quebec and west to eastern Texas and British Columbia (Fig. 278). In lllinois this species is distributed throughout the state (Fig. 278).

\section{Hybomitra lurida (Fallén)}

Hybomitra lurida Fallén (1817:5). Typelocality: Scandia.

Tabanus metabola McDunnough (1922: 239). Type-locality: Alberta. Nordegg.

Moderate size (13 mm); brownish black; subcallus denuded. shiny: eyes hairy; third antennal segment stout: abdomen with faint median triangles, yellowish sublateral spots on second. third, and fourth tergites; wings hyaline with dark yellow costal cell, faint brownish spots, and a tendency for veins toward bases of wings to be outlined in yellowish brown. Male eye facets scarcely differentiated: thorax and abdomen rather shiny: eyes hairy:

Previously, this species had been

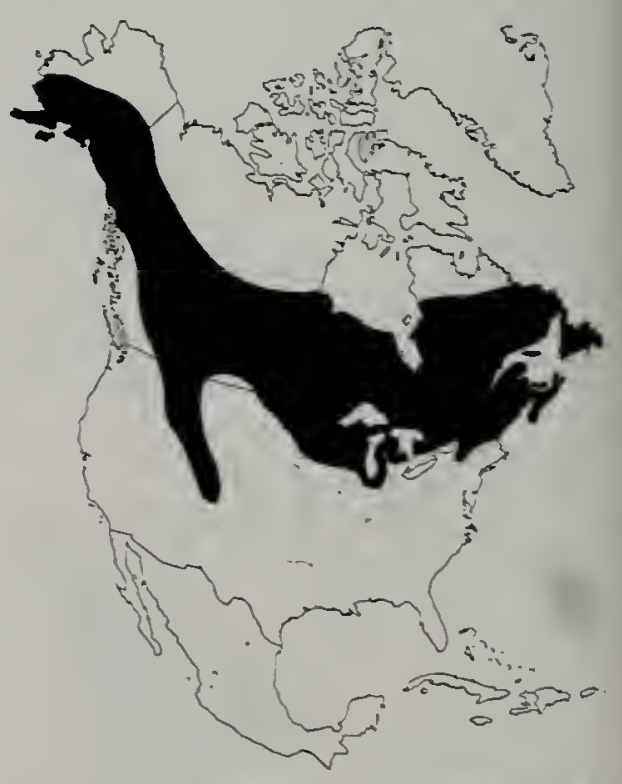

Fig. 279.-Distribution of Hybomltra lurida in North America. 
reported as $H$. metabola. However, it has been shown (Pechuman \& Stone 1968) that it is the same as the Old World lurida, and this name has priority.

Larvae (Fig. 268) are most commonly found in sphagnum bogs, but have also been taken in moss in swamps, ditches, and marshes (Teskey 1969).

$H$. lurida is a widespread northern species, extending from Massachusetts to northern Labrador and west to Colorado and Alaska (Fig. 279). This species has been collected only once in Illinois.

Illinois Records.-McHenry County; Algonquin.

\section{Hybomitra microcephala (Osten Sacken)}

Tabanus microcephalus Osten Sacken (1876:470). Type-locality: New Hampshire, White Mountains.

Moderate size ( $14 \mathrm{~mm}$ ); grayish black; subcallus pollinose; third antennal segment very slender; second palpal segment stout, especially at base; eyes hairy; prescutal lobe black; abdomen with three rows of grayish or pinkish gray spots, which are largest on second tergite; wings hyaline with yellow-

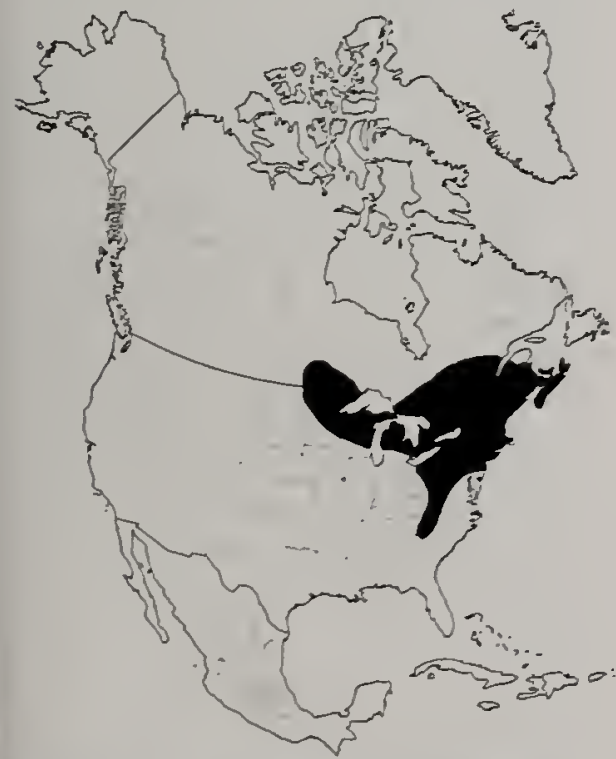

Fig. 280.-Distribution of Hybomitra microcephala in North America. ish costal cell and tendency for veins to be outlined in pale yellow; legs uniformly brown or reddish. Male eye facets scarcely differentiated; sublateral abdominal spots often reddish; eyes hairy.

Larvae (Fig. 261) have been collected from a well-decayed log (Teskey \& Burger 1976).

$H$. microcephala is a northeastern species, extending from South Carolina to southern Quebec and west to Manitoba (Fig. 280). As yet this species has not been collected in Illinois although specimens have been examined from Wisconsin and Ohio.

\section{Hybomitra minuscula (Hine)}

Tabanus minusculus Hine (1907:226).

Type-locality: Maine, Orono; New

York, Oswego; Massachusetts, Spring-

field; Canada.

Small to moderate size $(11 \mathrm{~mm})$; rather shining blackish brown; subcallus pollinose; second palpal segment very slender; third antennal segment practically without dorsal excision; eyes hairy; abdomen with considerable orange brown laterally; wings tinted, with tendency for veins to be outlined in deeper

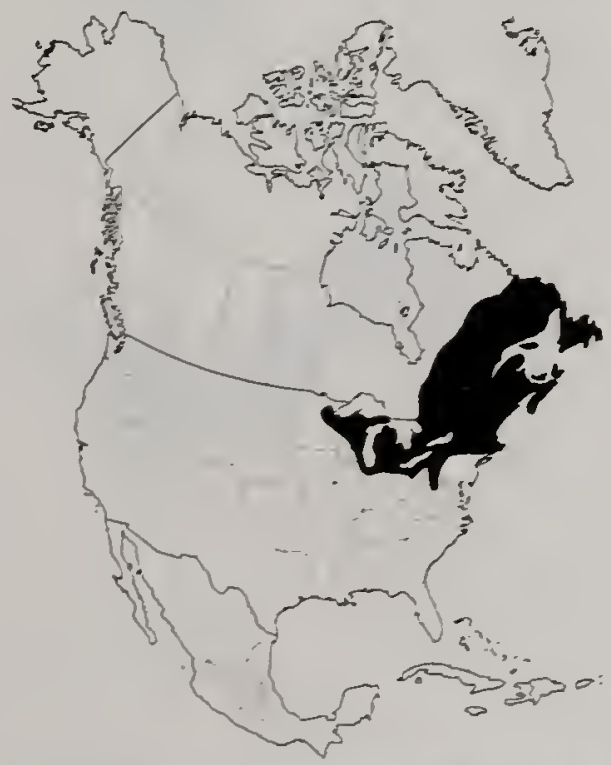

Fig. 281.-Distribution of Hybomitra minuscula in North America. 
tint, costal cell yellow. Male eye facets scarcely differentiated; eyes hairy.

Larvae (Fig. 266) are found in sphagnum (Pechuman 1972; Teskey 1969).

In Illinois adults appear in early August.

H. minuscula is a northeastern species, extending from Virginia to northern Labrador and west to Wisconsin (Fig. 281). This species has been collected only once in lllinois.

Illinois Records.-Lake County, Cedar Lake.

\section{Hybomitra pechumani Teskey \& Thomas}

Hybomitra pechumani Teskey \& Thomas (1979:346). Type-locality: Ontario, Alfred.

Moderate size (11 mm); palpi slender; eyes sparsely pilose; prescutal lobe reddish or brown; wings hyaline with dark yellow costal cell; abdomen with median row of gray triangles, larger sublateral pale spots. Male with upper eye facets enlarged, line of demarcation distinct; eyes densely pilose; sublateral pale abdominal markings sometimes pinkish; integument subshining.

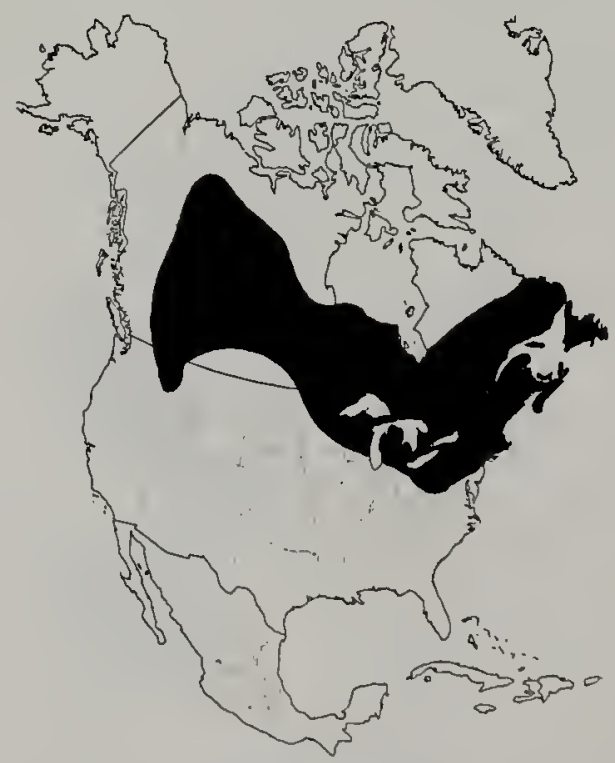

Fig. 282.-Distribution of Hybomitra pechumani in North America.
Most records in the literature of typhus Whitney refer to this species. However, the name typhus properly belongs to a less commonly collected species (Teskey \& Thomas 1979).

Larvae (Fig. 269) are found in wet moss in sphagnum bogs, in swamps, and at the edges of ponds and lakes (Teskey 1969, as $H$. typhus).

$H$. pechumani is a wide-ranging northern species, extending from northern Georgia to Labrador and west to Idaho, British Columbia, and the Northwest Territories (Fig. 282). As yet this species has not been collected in Illinois although specimens have been examined from central Wisconsin and Ohio.

\section{Hybomitra sodalis (Williston)}

Tabanus sodalis Williston (1887:139).

Type-locality: Connecticut.

Tabanus aestivalis Harris (1925:70). Nomen nudum.

Moderate size (15 mm); blackish: subcallus pollinose; basal portion of third antennal segment partly darkened; eyes with fine inconspicuous hairs; abdomen black with median row of grayish white triangles; wings tinted, especially anteriorly, costal cell dark yellow. Male eye facets scarcely differentiated; sides of abdomen usually tinted with orange brown; eves hairy.

Pechuman (1957) considered this species as a subspecies of trispila Wiedemann, but it has been shown (Pechuman 1960) that two sibling species are involved. They can be separated by the basal portion of the third antennal segment, which is partly black in sodalis and entirely orange in trispila.

Larvae (Fig. 270) have been found in wet soil near the edges of streams. in seepage areas, in moss in woodland swamps, and in relatively dry sod (Pechuman 1972; Teskey 1969).

In Illinois adults appear in early July and have been collected until late July:

H. sodalis is a northeastern species, extending from northern Georgia to New Brunswick and west to Minnesota (Fig. 283). In Illinois this species 


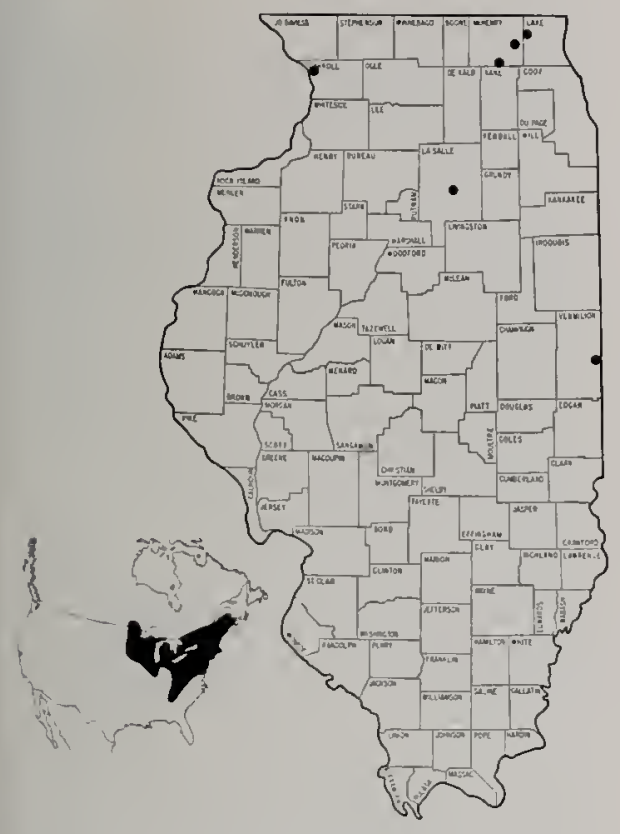

Fig. 283.-Distribution of Hybomitra sodalis in Illinois and North America.

has been collected at several localities in the northern half of the state (Fig. 283).

\section{Hybomitra tetrica hirtula (Bigot)}

Therioplectes hirtula Bigot (1892:641).

Type-locality: Washington Territory.

Moderate size $(15 \mathrm{~mm})$; blackish; palpi white, rather stout at base; beard white; frons rather wide, widened above; prescutal lobe brown; bifurcation with spur vein; abdomen with three rows of gray spots, sublateral ones sometimes with reddish tinge. Male readily associated with female by spur vein at bifurcation; upper eye facets scarcely differentiated; beard with some dark hairs.
Collecting in 1979 at the sole recorded locality in Illinois did not produce this species, and since Illinois is well out of its known range, it is possible that the specimens here recorded have an erroneous locality label.

The imnature stages are unknown.

In Illinois adults have been collected in early July.

$H$. tetrica hirtula is a western species, extending from Colorado to Manitoba and west to British Columbia and California, with a disjunct record in llimois (Fig. 284). This subspecies has been collected only once in Illinois.

Illinois records.-Ogle County, White Pines Forest State Park ( 7 miles W Oregon).

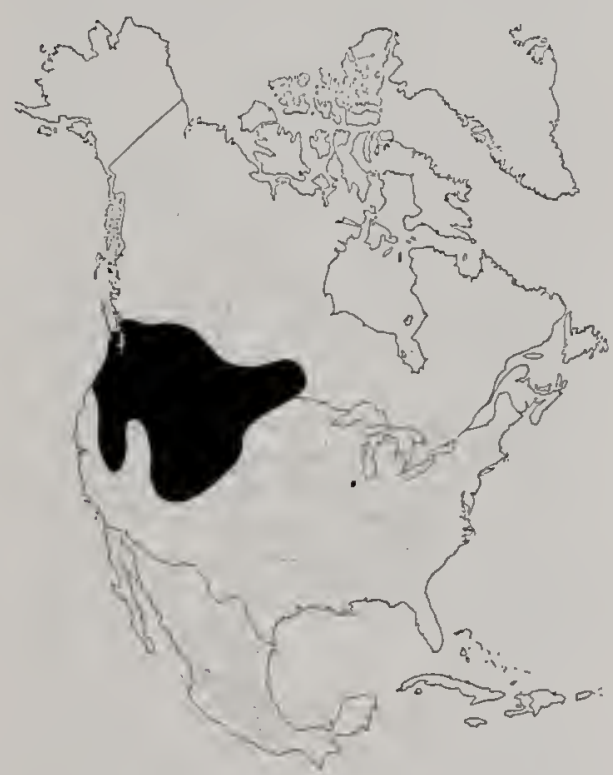

Fig. 284.-Distribution of Hybomitra tetrica hirtuia in North America. 


\section{LITERATURE CITED}

Aldrtch, J. M. 1892. A new genus and species of Tabanidae. Psyche 6:236-237.

Anderson, J. F, and F. R. Kneen. 1969. The temporary impoundment of salt marshes for the control of coastal deer flies. Mosquito News 29:239-243.

Andrews, P. L., and C. W. Wingo. 1975. Annotated list and keys to deer flies and horse flies (Diptera: Tabanidae) of Missouri. Missouri Academy of Science Transactions 9:3-20.

Anthony, D. W. 1962. Tabanidae as disease vectors. Pages 93-107 in K. Maromorosch, ed., Biological transmission of disease agents. Academic Press, NY. 192 p.

Beu.ARd, L. 1859. Saggio di ditterologia messicana. Parte 1. Torino. $80 \mathrm{p}$.

BequaERT, J. 1926. Medical report of the Hamilion Rice Seventh Expedition to the Amazon, in conjunction with the Department of Tropical Medicine of Harvard University, 1924-1925. Part 11. Medical and economic entomology: Harvard University, Institute for Tropical Biology and Medicine Contributions 4:155-257.

Bigot, J. M. F 1892. Descriptions de Diptères nouveaux. Mémoires de la Société Zoologique de France 5:602-691.

Brennan, J. M. 1935. The Pangoniinae of Nearctic America, Diptera: Tabanidae. University of Kansas Science Bulletin 22:249-401.

Burger, J. F. 1977. The biosystematics of immature Arizona Tabanidae (Diptera). American Entomological Society Transactions 103:145-258.

BurTON, J. J. S. 1975. The deer flies of Indiana. Great Lakes Entomologist 8:1-29.

CoQulleft, D. W. 1906. A new Tabanus related to punctifer. Entomological News 17:48.

Curran, C. H. 1927. Descriptions of Nearctic Diptera. Canadian Entomologist 59:79-92.

Davis, J. J. 1919. Contributions to a knowledge of the natural enemies of Phyllophaga. Illinois State Natural History Survey Bulletin 13:53-138.

DeFoliart, G. R., R. O. Anslow, R. P. Hanson, C. D. Morris, O. Papadopoulos, and G. E. SATHER. 1969. Isolation of Jamestown Canyon serotype of California encephalitis virus from naturally infected Aedes mosquitoes and tabanids. American Journal of Tropical Medicine and Hygiene 18:440-447.

DE GEER, C. 1776. Mémoires pour servir à l'histoire des Insectes. Vol. 6. Stockholm. $523 \mathrm{p}$.

DRURY, D. 1773. Illustrations of natural history. Vol. 2. London. $90 \mathrm{p}$.

Enderlein, G. 1925. Studien an blutsaugenden Insekten. 1. Grundlagen eines neuen Systems der Tabaniden. Mitteilungen aus dem Zoologischen Museum in Berlin 11:255-409.

Fabricius, I. C. 1775. Systema entomologiae. sistens insectorum classes, ordines, genera, species adiectis synonymis, locis, descriptionibus, observationibus. Flenshurgi et Lipsiae. 832 p.
1781. Species insectorum exhibentes eorum differentias specificas, synonyma, auctorum, loca natalia, metamorphosin. Vol. 2. Hamburgi et Kilonii. 517 p.

1794. Entomologia systematica emendata et aucta. Vol. 4. Hafniae. 472 p.

_. 1805 . Systema antliatorum secundum ordines, genera, species. Brunsvigae. 373 p.

Fatrchild, G. B. 1934. Notes on Tabanidae. Boston Society of Natural History Occasional Papers 8:139-144.

- 1937. A preliminary list of the Tabanidae (Diptera) of Florida. Florida Entomologist 19:58-63.

Faltén, C. F 1817. Diptera Sveciae. Tabanii et Xylophagei. Pages 3-14. Lundae.

Forster, J. R. 177I. Novae species insectorum. Centuria 1. London. $100 \mathrm{p}$.

Goonwin, J. T. 1966. An annotated list of the Tabanidae of Tennessee. Tennessee Academy of Science Journal 41:114-115.

1972. Immature stages of some eastern Nearctic Tabanidae (Diptera). Georgia Entomological Society Journal 7:98-109.

1973a. Immature stages of some eastern Nearctic Tabanidae (Diptera). 11. Genera of the tribe Diachlorini. Georgia Entomological Society Journal 8:5-11.

—. 1973b. Immature stages of some eastern Nearctic Tabanidae (Diptera). 1Il. The genus Tabanus Linnaeus. Georgia Entomological Society Journal 8:82-99.

1976a. Immature stages of some eastern Nearctic Tabanidae (Diptera). V1. Additional species of Chrysops Meigen. Florida Entomologist 59:343-351.

1976b. Immature stages of some eastern Nearctic Tabanidae (Diptera). V'll. Haematopota Meigen and Whitneyomyia Bequaert plus other Tabanini. Florida Entomologist 59:369-390.

Harris, T. W. 1925. Tabanidae. Pages 68-70 in Johnson, C. W., Diptera of the Harris Collection. Boston Society of Natural History Proceedings 38:57-99.

Hays, K. L. 1956. A synopsis of the Tabanidae (Diptera) of Mlichgan. University of Michigan. Museum of Zoology Miscellaneous Publications 98 .

_- and M. A. Tinwel... 1967. The larval habitats of some Tabanidae (Diptera) from Alabama and northwest Florida. Alabama Academy of Science Journal 38:197-202.

Hibler, C. P., J. L. Alxax:k, R. W'. Divis and I: Z. Aboelbaki. 1969. Elaeophorosis in deer and elk in the Gila Forest, New Mexico. Wildlife Disease Association Bulletin 5:27-30.

_, J. L. Adcock, G. H. G.ATEs, and R. Whiте. 1970. Experimental infection of domestic sheep and mule deer with Elaeophom schneider Wehr and Dikmans, 1935. Journal of Wildlife Diseases 6:110-111.

, G. H. Gates, R. White, and B. R. Donaldoson. 1971. Observatious on horseflies infected with larvae of Elaeophom schneideri. Journal of Wildlife Diseases $7: 43-45$. 
HiNe, J. S. 1900. Description of two new species of Tabanidae. Canadian Entomologist 32:247248.

1901. Change of name. Canadian Entomologist 33:28.

1903. Tabanidae of Ohio with a catalogue and bibliography of the species from America north of Mexico. Ohio State Academy of Science Special Papers 5.

1904. New species of North American

Tabanidae. Canadian Entomologist 36:55-56.

_ 1905. New species of North American Chrysops. Ohio Naturalist 6:39]-393.

1907. Descriptions of new North Ameri-

can Tabanidae. Ohio Naturalist 8:221-230.

1912. Five new species of North American Tabanidae. Ohio Naturalist 12:513-516.

1917. Descriptions of North American Tabanidae. Ohio Journal of Science 17:269-271. 1923. Some notes on American Tabanidae with the description of a new species from Africa. Ohio Journal of Science 23:204-206.

JAENNicke, F. 1867. Neue exotische Dipteren. Abhandlungen herausgegeben von der Senckenbergischen Naturforschenden Gesellschaft 6:311-408.

JAMNBACK, H. 1969. Bloodsucking flies and other outdoor nuisance arthropods of New York State. University of the State of New York, State Museum and Science Service Memoir 19.

, and W. WALL. 1959. The common saltmarsh Tabanidae of Long 1sland, New York. New York State Muscum and Science Service Bulletin 375.

Johannsen, O. A. 1935. Aquatic Diptera. Part 11. Orthorrhapha-Brachycera and Cyclorrhapha. Cornell University Agricultural Experiment Station Memoir 177.

Johnson, C. W. 1900. Some notes and descriptions of seven new species and one new genus of Diptera. Entomological News 11:323-328.

-1904. Some notes, and descriptions of four new Diptera. Psyche 11:15-20.

- 1912. The North American species of the genus Haematopota. Psyche 19:181-183.

Jones, C. M., and D. W. Anthony. 1964. The Tabanidae (Diptera) of Florida. U.S. Department of Agriculture Technical Bulletin 1295:] -85 .

Jones, T. H., and W. G. Bradley. 1923. Observations on Tabanidae (horseflies) in Louisiana. Journal of Economic Entomology 16:307-312.

J- and-_ 1924. Further observations on Tabanidae (horseflies) in Louisiana. Journal of Economic Entomology 17:45-50.

KRÖBER, O. 1926. Die Chrysops-Arten Nordamerikas einschl. Mexicos. Stettiner Entomologische Zeitung 87:209-353.

LiNnaEus, C. 1758 . Systema naturae per regna tria naturae. Vol. 1. Holmiae. 824 p.

LOEw, H. 1858. Zur Kenntniss der europäisclien Tabanus-Arten. Verhandlungen der Kaiserlich- königlichen Zoologisch-Botanischen Gesellschaft in Wien 8:573-612.

-_. - 1869. Diptera Americae septentrionalis indigena. Centuria octava. Berliner Entomologische Zeitschrift 13:1-52.

Mackerras, 1. M. 1954. The classification and distribution of Tabanidae (Diptera). 1. General Review. Australian Journal of Zoology 2:431-454.

Macquart, J. 1834. Histoire naturelle des Insectes. -Diptères, Tone premier. In N. E. Roret, ed., Collection des suites à Buffon. Paris. $578 \mathrm{p}$.

_- 1838. Diptères exotiques nouveaux ou peu connus. Mémoires de la Société Royale des Sciences, de l'Agriculture et des Arts de Lille 1838(2):9-225.

-1847. Diptères exotiques nouveaux ou peu connus. $2^{c}$ supplément. Mémoires de la Société Royale des Sciences, de I'Agriculture et des Arts de Lille 1846:21-120.

1850. Diptères exotiques nouveaux ou peu connus $4^{\mathrm{e}}$ suppléntent [part]. Mémoires de la Société des Sciences, de l'Agriculture et des Arts de Lille 1849:309-479.

1855. Diptères exotiques nouveaux ou peu connus. $5^{\mathrm{C}}$ supplément. Mémoires de la Société Impériale des Sciences, de l'Agriculture et des Arts de Lille 1854:25-156.

MCALPINE, J. F. 1961. Variation, distribution and evolution of the Tabanus (Hybomitra) frontalis complex of horse flies (Diptera: Tabanidae). Canadian Entomologist 93:894-924.

McDunnough, J. 1922. Two new Canadian Tabanidae (Diptera). Canadian Entomologist 54:238-240.

Meyer, R. W., and D. P. Sanders. 1975. New locality records in the genus Chrysops (Diptera: Tabanidac) in Indiana. Indiana Academy of Science Proceedings 85:271-273.

Osten Sacken, C. R. 1875. Prodrome of a monograph of the Tabanidae of the United States. Part 1. The genera Pangonia, Chrysops, Siluius, Haematopota, Diabasis. Boston Society of Natural History Memoirs 2:365-397.

1876. Prodrome of a monograph of the Tabanidae of the United States. Part 11. The genus Tabanus. Boston Society of Natural History Memoirs 2:421-479.

1878. Prodrome of a monograph of the Tabanidae of the United States. Supplement. Boston Natural History Society Memoirs 2:555-560.

Palisot de Bfalvois, A. M. F. J. 1806. lusectes recueillis en Afrique et en Amérique dans les royaumes d'Oware et de Benin, à SaintDomingue et dans les États-Unis, pendaut les années 1786-1797. Pages 41-56. Paris.

1809. Insectes recueillis en Afrique et en Amérique dans les royaumes d'Oware el de Benin, à Saint-1)omingue et dans les Etats-Unis, pendant les années 1786-1797. Pages 89-100. l'aris. 
1819. Insectes recueillis en Afrique et en Amérique dans les royaumes d'Oware et de Benin, à Saint-Domingue et dans les États-Unis, pendant les années 1786-1797. Pages 208-224. Paris.

Pechuman, L. L. 1949. Some notes on Tabanidae (Diptera) and the description of two new Chrysops. Canadian Entomologist 81:77-84.

. 1957. The Tabanidae of New York. A distributional study. Rochester Academy of Science Proceedings 10:121-179.

1960. Some new and little-known North American Tabanidae (Diptera). Canadian Entomologist 92:793-799.

- 1962. A new Nearctic Tabanus of the fulvulus group. Brooklyn Entomological Society Bulletin 57:66-70.

1972. The horse flies and deer flies of New York (Diptera, Tabanidae). Cornell University, Agricultural Experiment Station, Search Agriculture 2(5): 1-72.

- 1973. Horse flies and deer flies of Virginia (Diptera: Tabanidae). The insects of Virginia: No. 6. Virginia Polytechnic Institute and State University, Research Division Bullein $81.92 \mathrm{p}$.

- 1981. Notes on Atylotus and description of a new species from eastern North America (Diptera: Tabanidae). Entomological News 92:1-6.

, and A. Stone. 1968. A new synonymy in Hybomitra. Entomological Society of WashingIon Proceedings 70:302.

, and H. J. TeSKEv. 1967. A new eastern Nearctic Chrysops (Diptera: Tabanidae).Canadian Entomologist 99:645-650.

PuILIP, C. B. 1931. The Tabanidae (horseflies) of Minnesota, with special reference to their biologies and taxonony. University of Minnesota Agricultural Experiment Station Technical Bulletin 80. 132 p.

1936a. Tabanus rhombicus and related western horseflies. Canadian Entomologist 68:148-160.

__ 1936b. New Tabanidae (horseflies) with notes on certain species of the longus group of Tabanus. Ohio Journal of Science 36: 149-156.

1936c. The furcatus group of western North American llies of the genus Chnisops (Diptera: Tabanidae). Entonological Society of Washington Proceedings 37:153-161.

1941. Notes on Nearctic Pangoniinae (Diptera, Tabanidae). Entomological Society of Washington Proceedings 43:113-130.

1942. Notes on Nearctic Tabanidae. Part 111. The Tabanus lineola complex. Psyche 49:25-10.

_- 1950a. New North American Tabanidae (Diptera). Part 1. Pangoniinae. Entomological Society of America Annals 42:451-460.

1950b. New North American Tabanidae (Diptera). III. Notes on Tabamus molestus and related horseflies with a prominent single row of triangles on the abdomen. Entomological Society of America Annals 43:240-248.

1952. The Linnean and Degeerian species of American Tabanidae (Diptera). Entomological Society of America Annals 45:310-314. 1954. New North American Tabanidae.

VIII. Notes on and keys to the genera and species of Pangoniinae exclusive of Chysops. Revista Brasileira de Enıomologia 2:13-60. 1955. New North American Tabanidae. IX. Notes on and keys to the genus Chnsops Meigen. Revista Brasileira de Entomologia 3:47-128.

- 1957. A new era in ideas of systematic relationships of world Tabanidae (Diptera) inaugurated by Mackerras, and its impact on nomenclature of horseflies of the western hemisphere. Entomological Sociely of America Annals 50:550-555.

1959. New North American Tabanidae. $\mathrm{X}$. Notes on synonymy; and description of a new species of Chnysops. American Entomological Society Transactions 85:193-217.

. 1961. New North American Tabanidae. XIII. Change of name for a well-known species of Chrysops. Entomological News 72: 160-162.

. 1965. Family Tabanidae. Pages 319-342 in A. Stone, C. W. Sabrosky; W: W: Wirth. R. H. Foote, and J. R. Coulson, eds., A catalog of the Diptera of America north of Mexico. U. S. Department of Agriculture Agricultural Handbook 276.

RiCARDO, G. 1911. A revision of the species of Tabanus from the Oriental region, including notes on species from surrounding countries. Indian Museum Records 4:111-255.

Richards, L. L., and K. L. KNight, 1967. The horse flies and deer flies of lowa (Diptera: Tabanidae). Iowa State Journal of Science 41:313-362.

RoberTs, R. H., and R. J. Dicke. 1958. Wisconsin Tabanidae. Wisconsin Academy of Science. Arts and Letters Transactions 47:23-42.

$\mathrm{S}_{\mathrm{A}}$; , T. 1823. Descriptions of dipterous insects of the United States. Academy of Natural Sciences of Philadelphia Journal 3:9-54.

SChOmberc:, O., and D. E. Howell. 1955. Biological notes on Tabanus abactor Phil. and equalis Hine. Journal of Economic Entomolog: 48:618-619.

Scuwarnt. H. H. 1936. Horseflies of Arkansas. University of Arkansas Agricultural Experiment Station Bulletin 332. 66 p.

- and D. G. HALL. 1930. Preliminary studies on Arkansas horseflies. University of Arkansas Agricultural Experiment Station Bulletin $256.27 \mathrm{p}$.

Sc:IWEgman. J. E. 1973. Comprehensive plan for the lllinois Nature Preserves Sistem. Part 2. The natural divisions of Illinois. Illinois Nature Preserves Commission. $32 \mathrm{p}$.

Srone. A. 1935. Notes on Tabanidae (Diptera). Entomological Society of Washington Proceedings $37: 11-21$. 
1938. The horsellies of the sublamily Tabaninae of the Nearctic Region. U.S. Department of Agriculture Miscellaneous Publications $305.171 \mathrm{p}$.

Teskey, H. J. 1962. A method and apparatus for collecting larvae of Tabanidae (Diptera) and other invertebrate inhabitants of wetlands. Entomological Society of Ontario Proceedings 92:204-206.

1969. Larvae and pupae of some eastern North American Tabanidae (Diplera). En. tomological Society of Canada Memoirs 63. $147 \mathrm{p}$.

—, and J. F. Burger. 1976. Further larvae and pupae of eastern North American Tabanidae (Diptera). Canadian Entomologist 108:10851096.

Hybomitra typhus and description of a new species previously confused with it (Diptera: Tabanidae). Canadian Entomologist 111:343350.

Thompson, P. H. 1975. Larval habitats of Tabanus subsimilis subsimilis Bellardi in southeast Texas (Diptera: Tabanidae). Entomological Society of Washington Proceedings 77:494-500.

- E. J. Gregg, D. R. Charanza, R. A. SausedA, and J. W. Holmes, JR. 1978. Habitats of larval Tabanidae (Diptera) in south Texas. Entomological Society of Washington Proceedings 80:296-308.

TinWEll, M. A. 1973. The Tabanidae (Diptera) of Louisiana. Tulane Studies in Zoology and Botany 18:1-95.

W. D. Dean, M. A. Tidwell, G. P. Conbs, D. W. Anderson, W. O. Cowart, and R. C. Axtell. 1972. Transmission of hog cholera virus by horseflies (Tabanidae: Diptera). American Journal of Veterinary Research 33:615-622.

, and M. A. TIDWELL. 1973. Larvae and pupae of five eastern North American Tabanus species (Diptera: Tabanidae). Entomological Society of America Annals 66:390-398.

Townsend, C. H. T. 1895. Contributions to the dipterology of North America. 11. Tabanidae, Conopidae, Tachinidae, etc. American Entomological Society Transactions 22:55-80.
WALKER, F. 1848. List of the specimens of dipterous insects in the collection of the British Museum. Vol. 1. London. 229 p.

1850. Diptera. Vol. 1. Pages $1-76$ in W.

W. Saunders, ed., Insecta Saundersiana. London.

1871. List of Diptera collected in Egypt and Arabia, by J. K. Lord, Esq; with descriptions of the species new to science. Entomologist 88:255-263.

Walton, W. R. 1918. Neochrysops globosus. Page 192 in W. L. McAtee and W. R. Walton, District of Columbia Diptera: Tabanidae. Entomological Society of Washington Proceedings 20:188-206.

WEBR, J. L., and R. W. WELLS. 1924. Horse-flies: biologies and relation to western agriculture. U. S. Department of Agriculture Bulletin 1218. $36 \mathrm{p}$.

WhitNey, C. P. 1879. Descriptions of some new species of Tabanidae. Canadian Entomologist 11:35-38.

1904. Descriptions of some new species of Tabanidae. Canadian Entomologist 36:205207.

1914. Descriptions of four new Tabanidae, with remarks upon Chrysops cursim. Canadian Entomologist 46:343-346.

Wiedenann, C. R. W. 1821. Diptera exotica. [Part] I1. Kiliae. $101 \mathrm{p}$.

1828. Aussereuropäische zweiflügelige Insekten. Vol. I. Hamm. 608 p.

WiLliston, S. W. 1887. Notes and descriptions of North American Tabanidae. Kansas Academy of Science Transactions 10:129-142.

WILson, B. H. 1969. Tabanid larval habitats and population densities in an alluvial area in southern Louisiana. Entomological Society of America Annals 62:1203-1204.

Wricht, R. E., R. O. Ansiow, W. H. THOMPSON, G. R. DeFoliart, G. Seawricht, and R. P. HANSON. 1970. Isolations of LaCrosse virus of the California group from Tabanidae in Wisconsin. Mosquito News 30:600-603.

Wulp, F. M. VAN DER. 1867. Eenige NoordAmeticaansche Diptera. Tijdschrift voor Entomologie 10:125-164. 
abdominalis, Tabanus, 78, 84 aberrans, Chrysops, 35

Acknowledgments, 1 actaeon, Tabanus, 89 aestivalis, Tabanus, 112 aestuans, Chrysops, 36 americanus, Tabanus, 59, 79 annulatus, Leucotabanus, 63 annulatus, Tabantus, 63 apicalis, Tabanus, 100 approximans, Chrysops, 59 arborealis, Tabanus, 101 areolatus, Chrysops, 57 astuta, Hybomitra, 106 astutus, Tabanus, 106 ataenia, Diabasis, 59 ater, Chrysops, 37 atratus atratus, Tabanus, 79

Atylotus, 61

baal, 94

bicolor, 61

ohioensis, 61

tenessensis, 87

thoracicus, 62

uoodi, 62

banl, Atylotus, 94

baltimorensis, Tabanus, 92

beameri, Chrysops, 38

benedictus, Tabanus, 91

bicolor, Atylotus, 61

bicolor, Tabanus, 80

brunneus, Chrysops, 38

Buplex, 19

calens, Tabaniss, 80

callidus, Chrysops, 39

calvus, Chrysops, 40

canadensis, Chrysops, 45

canadensis, Tabanus, 108

canifrons, Chrysops, 44

carbonarius, Chrysops, 40

carbonarius nubiapex, Chrysops, 37

carolinensis, Hamatabanus, 102

carolinensis, Tabanus, 102

celatus, Chrysops, 41

celer, Chrysops, 41

cerastes, Tabanus, 102

Chlorotabanus, 60

crepuscularis, 60

chrysocoma, Goniops, 20

chrysocoma, Pangonia, 20

Chrysops, 21

aberrans, 35

aestuans, 36

approximans, 59

areolatus, 57

ater. 37

beameri, 38

brunnetus, 38 callidus, 39

caltrus, 40

canadensis, 45

canifrons, 44

carbonarius, 40

carbonarius nubiapex, 37

celatus, 41

celer, 41

cincticornis, 41

convergens, 59

cuclux, 42

dacne, 42

dimmocki, 43

excitans, 43

fallax, 46

ferrugatus, 59

flavidus, 44

fratermus, 56

frigidus, 45

fugax, 37

fulvistigma, 45

geminatus, 46

impunctus, 46

indus, 47

lincatus, 57

luteopennis, 48

macquarti, 48

mitis, 49

mocchus, 49

mocrens, 36

montanus, 50

niger, 51

obsoletus, 56

ormatus, 57

pallidus, 44

pikei, 51

pilumnus, 47

pudicus, 52

quadrivittatus, 58

reicherti, 52

sackeni, 53

separatus, 54

sequax sequax, 54

sequar tau, 55

strintus, 55

univittatus, 56

upsilon, 57

vittatus, 57

wiedemanni, 56

cincta, Hybomitra, 107

cincticonis, Chrysops, 41

cinctus, Tabanus, 107

Classification, 15

coesiofarciatus, Tabanus, 80

coffeatus, Tabanus, 89

Collection and Preservation, 12

Control, 12

convergens, Chrysops, 59

costalis, Tabamus, 92

crepuscularis, Chlorotabanus, 60 
crepuscularis, Tabanus, 60

cuclux, Chrysops, 42

cymatophorus, Tabanus, 81

dacne, Chrysops, 42

dawsoni, Tabanus, 94

Diabasis, 59

ataenia, 59

Dinchlorus, 59

ferrugatus, 59

difficilis, Hybumitra, 107

difficilis, Tabanus, 107

dimmocki, Chrysops, 43

Economic Importance, 11

epistates, Hybomitra, 107

epistates, Tabanus, 107

equalis, Tabanus, 81

erythrotelus, Tabanus, 93

excitans, Chrysops, 43

exilipalpis, Tabanus, 82

exul, Tabanus, 98

fairchildi, Tabanus, 82 fallax, Chrysops, 46 ferrugatus, Chrysops, 59

ferrugatus, Diachlorus, 59

flavidus, Chrysops, 44

flavus, Tabamus, 60

fraternus, Chrysops, 56

fretus, Tabanus, 110

frigidus, Chrysups, 45

frontalis, Hybomitra. 108

frontalis, Tabanus, 108

fugax, Chrysops, 37

fulvescens, Tabanus, 61

fulvistigma, Chrysops, 45

fulvofrater. Tabanus, 83

fulvulus, Tabanus, 83

geminata, Merycomyia, 20

geminatus, Chrysops, 46

giganteus, Tabanus, 80

gladiator, Tabanus, 83

globosus, Neochrysops, 58

Goniops, 20

chrysocoma, 20

hippoboscoides, 20

guttiferus, Tabanus, 110

Habits of Adults, 11

Haematopota, 60 rara, 60

Hamatabanus, 102 carolinensis, 102

hinei, Hybomitra, 109

hinei, Tabanus, 109

hippoboscoides, Goniops, 20

hirtioculatus, Tabanus, 102

hirtuln. Therioplectes, 113

Hybomitra, 103

astuta, 106

cincta, 107

difficilis, 107

epistates, 107

frontalis, 108

hinei, 109 illota, 109

lasiophthalma, 110

lurida, 110

microcephala, 111

minuscula, 111

pechumani, 112

sodalis, 112

tetrica hirtula, 113

illota, Hybomitra. 109

illota, Tabanus, 109

Immature Stages, 8

impunctus, Chrysops, 46

incisus, Tabanus, 108

indus, Chrysops, 47

isabellina, Stonemyza, 19

Key to Genera of Tabanidae, 15

labradorensss, Tylestypia, 108

lasiophthalma, Hybomitra, 110

lasiophthalmus, Tabanus, 110

Lencotabanus, 63

annulatus, 63

limbatinevris, Tabanus, 84

limbatus, Tabanus, 79

lineatus, Chrysops, 57

lineatus, Tabanus, 80

lineola. Tabanus, 86

lubalis, Chrysops, 43

lurida, Hybomitra, 110

luteopennis, Chrysops, 48

macquarti, Chnysops, 48

manifestus, Tabanus, 92

marginalis, Tabanus, 86

melanocerus, Tabanus, 87

Merycomyin, 20

gemmata, 20

$\operatorname{mixt} n, 20$

uhitneyi, 20

metabola, Tabanus, 110

microcephala, Hybomitra, 111

microcephalus, Tabanus, 111

minuscula, Hybomitra, 111

minusculus, Tabanus, II I

mitis, Chrysops, 49

muxia, Merycomyia, 20

moechus, Chrysops, 49

moerens, Chrysops, 36

molestus, Tabanus, 87

montanus, Chyysops, 50

mularis, Tabanus, 88

mutatus, Tabanus, 83

Natural Divisions of 1llinois, ?

Natural Enemies, 11

Natural History, 8

Neochrysops, 58

globusus, 58

niger, Chrysops, 51

niger. Tabanus, 79

nigrescens, Tabanus, 88

nigricans, Tabanus, 97

nigripes, Tabanus, 89

niwosus, Tabanus, 86

notabilis, Tabanus, 110 
novaescotiae, Tabanus, 89

obsoletus, Chrysops, 56 ohioensis, Atylotus, 61 ohioensis, Tabanus, 61 orbicallus, Tabanus, 90 ornatus, Chrysops, 57

pallidescens, Tabanus, 90

pallidius, Chrysops, 44

pallidus, Tabanus, 80

Pangonia, 20

chrysocoma, 20

pigra, 19

rasa, 19

pechumani, Hybomitra, 112

petiolatus, Tabanus, 91

pigra, Pangonia, 19

pikei, Chrysops, 51

pilumnus, Chrysops, 47

plumbeus, Tabanus, 79

palitus, Therioplectes, 109

proximus, Tabanus, 91

pruinosus, Tabanus, 62

pudicus, Chrysops, 52

pumilus, Tabanus, 92

punctipennis, Tabanus, 110

quadrivittatus, Chrysops, 58 quadrivittatus, Silvius, 58 quinquelineatus, Tabanus, 100 quinquevittatus, Tabanus, 92

rara, Haematopota, 60 rasa, Pangonia, 19 rasa, Stonemyia, 19 redactus, Tabanus, 110 reficeps, Tabanus, 61 reicherti, Chrysops, 52 reinwardtii, Tabanus, 93 rondanii, Tabanus, 59 ruficornis, Tabanus, 79

Sabanus, 108 septentrionalis, 108 sackeni, Chrysops, 53 sackeni, Tabanus, 93 sagax, Tabanus, 94 scitus, Tabanus, 102 scutellaris, Tabanus, 95 separatus, Chrysops, 54 septentrionalis, Sabanus, 108 sequax sequax, Chrysops, 54 sequax tau, Chrysaps, 55

Silvius, 58 quadrivittatus, 58 similis, Tabanus, 94 socius, Tabanus, 107 sodalis, Hybomitra, 112 sodalis, Tabanus, 112 sparus milleri, Tabanus, 96 sparus sparus, Tabanus, 95

Stonemyia, 19 isabellina, 19 rasa, 19

striatus, Chrysops, 55

styguis, Tabanus, 96 sublongus, Tabanus, 96 subniger, Tabanus, 97 subsimilis, Tabanus, 97 sulcifrons, Tabanus, 98 superjumentarius, Tabanus, 99

Tabanus, 63

abdominalis, 78,84

actaean, 89

aestivalis, 112

americanus, 59, 79

annulatus, 63

apicalis, 100

arborealis, 101

astutus, 106

atratus atratus, 79

baltimarensis, 92

benedictus, 91

bicolor, 80

calens, 80

canadensis, 108

carolinensis, 102

cerastes, 102

cinctiss, 107

coesiofasciatus, 80

coffeatus, 89

costalis, 92

cymatophoris, 81

dou'soni. 94

difficilis, 107

epistates, 107

equalis, 81

ervthrotelus, 93

exilipalpis, 82

exul, 98

fairchildi, 82

flarns, 60

fretus, 110

frontalis, 108

fulvescens, 61

fulvofrater, 83

fulvulus, 83

giganteus, 80

gladiator, 83

guttiferus, 110

hinei. 109

hirtioculatus, 102

illota, 109

incisus, 108

lasiophthalmus, 110

limbatinezrns, 84

limbatus, 79

lineatus, 80

lineola, 86

manifestius, 92

marginalis, 86

melanocerius, 87

metabola, 110

microcephalus. 111

minusculus, 111

malestus, 87

mularis, 88

mutatus, 83

niger, 79

nigrescens, 88 
nigricans, 97

nigripes, 89

nivasus, 86

notabilis, 110

novaescotiae, 89

ahioensis, $6 \mathbf{1}$

orbicallus, 90

pallidescens, 90

pallidus, 80

petiolatus, 91

plumbeus, 79

proximus, 91

pruinosus, 62

pumilus, 92

punctipennis, 110

quinquelinealus, 100

quinqueviltatus, 92

redactus, 110

reficeps, 61

reinuardtii, 93

rondanii, 59

ruficornis, 79

sackeni, 93

sagax, 94

scitus, 102

scutellaris, 95

similis, 94

sacius, 107

sodalis, 112

sparus milleri, 95

sparus sparus, 96

slygius, 96

sublongus, 96

subniger, 97

subsimilis, 97

sulcifrons, 98

superjumentarius, 99

lectus, 98

thoracicus, 62

trimaculatus, 99

turbidus, 100

uniformis, 81

validus, 79 variegatus, 98

venustus, 101

vicarius, 92

vittiger schwardit, 97

vivax, 101

whitney?, 20

wilsoni, 102

yulenus, 91

tau, Chrysops sequax, 55

Taxonomic Characters, 15

Taxonomic Treatment, 19

tectus, Tabanus, 98

tenessensis, Atylotus, 87

tetrica hirtula, Hybomitra, 113

Therioplectes, 109

hirtula, 113

politus, 109

thoracicus, Atyloitus, 62

thoracicus, Tabanus, 62

trimaculatus. Tabanus, 99

turbidus, Tabanus, 100

Tylostypia, 108

labradorensis, 108

unifomis, Tabanus, 81

univittatus, Chrysops, 56

upsilon, Chrysops, 57

validus, Tabanus, 79

variegatus, Tabanus, 98

venustus, Tabanus, 101

vicarius, Tabanus, 92

vittatus, Chrysops, 57

vittiger schu'ardti. Tabanus, 97

vivax, Tabanus, 101

whitneyi, Merycomyia, 20

whilneyi, Tabanus, 20

wiedemanni. Chrysops, 56

uilsoni, Tabanus, 102

woods, Alylotus, 62

yulenus, Tabanus, 91 
Rebecch Grosser, B.S. Technural Assustant Aleta A. HOLT, B.S., Technical Asststant JEANine M. Kasprowicz. B.S., Technucal Assistant EDWARD A. LJsowSk', M.S., Technucal Assistant Christine T. Miller, B.A., Technical Asszstant Michael E. Retzer, M.A., Terhnical Assestant LIANE B. SUlowaY, M.S. Technical Assistant MARK J. WETZEL, M.S., Technical Asststant

\section{Section of Wildilfa Reaearch}

Glen C. SANDerson, Ph.D., Wildhe Specialest and Head

Frank C. Beulrose, Sc.D., Wildlife Speculust and Principal Scientst

WILLiam L. ANDERSON, M.S., Wildlife Ecologtst

William R. EDwards, Ph.D., Wildlife Ecologist

JeAn W. Graber, Ph.D., Omithologist

Richard R. Graber, Ph.D., Ornthologzit

harold C. Hanson, Ph.D., Wildhe Spectalest

ChARtES M. NixON, MI.S., Wildlife Ecologzst

W. W. Cochran, JR., B.S., Assochate Wildife Spectalut

Stephen P. Haiera, Ph.D., Assocute Wildlife Ecologat

Ronald L. Westemeler, M.S., Associate Wildlife Ecologist

Christopher D. BlernetT, Ph.D., Assistant Wildife Erologast

Lonnie P. Hansen, Ph.D., Assistant Wildife Ecologist

Ronald P Larkin, Ph.D. Assistant Wildlife Ecologrst

RICHARD E. WARAER. Ph.D., Assistant Wildlife Ecologzst

SusANNe G. WOOD, Ph.D.. Assestant Chemust

JOHN E, BLHNERKEMPE. M.S., Asststant Suppotive Sctentest

ROBert D. Crompton, Jumior Professional Scientast

Ronald E. Dlzan, Junior Professional Scientust

Cynthia G. Jachison, B. A. Jumor Professional Scientut

JAMEs W. SEeTS, Junior Professional Scienist

YU-CHU AU, M.S., Laboratory Assistant
Richard J Siemers, M.S., Labotasoon Ásestant

JAMES CheEssig. M.S. Fueld Asserant

Elizabeth A. Asderson, Technical Aisertant

H. KATHLEEN ARCHER, B.S., Technical Assistant VICTORIA ATCHLEY, Technical Assistan!

PACL Breu'ER, B.S., Techriscal Assestani

Grfgorv A. Perkins, M.A. Technical Ausistant

GARY E. POTTS, B.S., Technical Assestant

\section{Supporting Services}

Melvin E. SChwartz, Admanseratue Assestane and ['ret Head Phiti.Is S. Clark, Maling, Distribution, and Stackroom Serraces Wilma G. Dillmax, Fisal Assestant and Propert Confrol

PatTy L. Dizan, Word Processing Courdinator

LARR) D. Gross, Assistant For Operations

SU'E M. HALE, Grants and Constarts Offied

JAMES MCN AMARA, Operations Assistant

JONC. REED, Juntat Technical Asstriant

Chris Rohl, Operations Assestant

JaCQI'E SANDER. Personnel Offucer

Chris Willson, Operathons .Assestant

\section{Publications and Pubile Relations}

ROBLRT M. ZEWADShi, M.S., Techneal Eduor

SHIRLE) MCClellaN. B.S., Assornate Technual Edilor

EVA STECER, B.A. Assistani Technzeal Ederor

LlOT DE MERE, Technical Illustrator

LESLIE WOODRL'M, Techrical Photagrapher

\section{Tochnical Llbrany}

CARLA Heister, M.A. Technecal Lubranan

Monica Ll'Sk. Libtan Technical . Assistant

CONSULTANTS AND RESEARCH AFFILIATES: Aquatic Biology, Margarel Balbach, Ph.D., Assocuate Professer, Deparimeni of

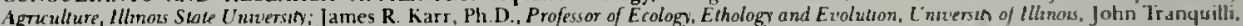
Ph.D. Assoctate Professtonal Scientast, Illinos Department of Conservation; and Cregory S. Whill. Ph D., Professor of Genetho and Developmeni, Unuersity of Illinots. Botany and Plant Pathology, Jean D. Schahnecht, Ph.D., Assoctate Professor of Life Sriences, Induane State Unuersty. Terre Haute; Systematic Entomology, Roderich R. Irwin. Chicago. Illinow, Wildlife Research, Willard D. Klinstra,

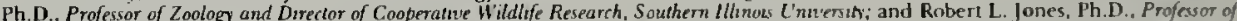
Soll Mfineralogy and Ecology. Universiy of Illinos; Parasitology, Norman D. Levine. Ph.D., Professor of Veternman Parasilolog, letennan Research and Zoology, and Director of the Center for Human Ecology, Unuversity of Illinoss; Entomology, Raben L. Meicalf, Ph D.. Professor of

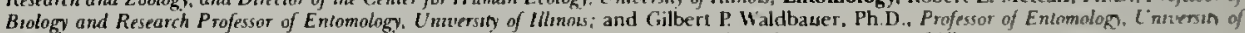
Illinos: Statistics, Horace W. Norton, Ph.D., Professor of Statsitical Destgn and Analysts. L'nuersin of Illinass. 



\section{.}




\section{Some Publications of the ILLINOIS NATURAL HISTORY SURVEY}

\section{BULLETIN}

Volume 32, Article 1.-Waterfowl Populations and the Changing Environment of the 111inois River Valley. Frank C. Bellrose, Fred L. Paveglio, Jr., and Donald W. Steffeck. August 1979. 54 p., index.

Volume 32, Article 2.-Primary Insect Types in the Illinois Natural History Survey Collection, Exclusive of the Collembola and Thysanoptera. Donald W. Webb. July 1980. 138 p., index.

Volume 32, Article 3.-The Genera of Nearctic Therevidae. Michael E. Irwin and Leif Lyneborg. November 1980.85 p., index.

Volume 32, Article 4.-The Lake Sangchris Study: Case History of an Illinois Cooling Lake. R. Weldon Larimore and John A. Tranquilli, eds. August 1981. 459 p., index.

\section{BIOLOGICAL NOTES}

109.-Illinois Birds: Ciconijformes. Jean W. Graber, Richard R. Graber, and Ethelyn L. Kirk. August 1978. $80 \mathrm{p}$.

110.-Illinois Birds: Sylviidae. Jean W. Graber, Richard R. Graber, and Ethelyn L. Kirk. July 1979. 22 p.

111.-Monitoring the Scasonal Appearance and Density of the Black Cutworm with a Virgin Female Trap. Lynn Pautler, William G. Ruesink, Hans E. Hummel, and William H. Luckınann. July 1979. $7 \mathrm{p}$.

112. - The Life History of the Least Darter, Etheostoma microperca, in the Iroquois River, 1 llinois. Brooks $\mathrm{M}$. Burr and Lawrence $\mathbf{M}$. Pagc. August 1979. 16 p.

113.-The Life Histories of Etheostoma olivaceum and Etheostoma striatulum, Two Species of Darters in Central Tennessee. Lawrence M. Page. Augusi 1980. 14 p. 114.--1dentification and Descriptions of the UItimate Instar Larvae of Hydraecia immanis (Hop Vine Borer) and $H$. micacea (Potato Stem Borer) (Lepidoptera: Noctuidae). George L. Godfrey: February 1981. 8 p.

115.-Illinois Pheasants: Population, Ecolog), Distribution, and Abundance, 1900-1978. Richard E. Warner. August 1981. 24 p.

116.-Effects of Ingested Lead-Iron Shot on Mallards. Glen C. Sanderson, Horace W. Norton, and Sarah S. Hurley. August 1981. $16 \mathrm{p}$.

117.-The Life History of the Tennessee Snubnose Darter, Etheostoma simoterum, in Brush Creek, Tennessee. Lawrence M. Page and Richard L. Mayden. August 1981. 12 p.

118.-Illinois Birds: Wood Warblers. Jean W' Graber, Richard R. Graber, and Ethelyn L. Kirk. April 1983. 144 p.

\section{CIRCULAR}

49.-The Dunesland Heritage of Illinois. Herber H. Ross. August 1963 (Reprinted May 1974). $28 \mathrm{p}$.

51.-1llinois Trees: Selection, Planting, and Care. J. Cedric Carter. Narch 1977 (Third printing). $123 \mathrm{p}$.

52.-Fertilizing and Watering Trees. Dan Neely and E. B. Himelick. December 1971 (Third printing). $20 \mathrm{p}$.

54.-Corn Rootworm Management in Canning Sweet Corn. W. H. Luckmann, J. T. Shaw, D. E. kublman, R. Randell, and C. D. LeSar. March 1975. $10 \mathrm{p}$.

55.-Observing, Photographing, and Collecring Plants. Kenneth R. Robertsous. August 1980. $62 \mathrm{p}$.

No charge is made for publications of the LLIINOIS NATURAL. HISTORY SU'RIE). A single copy of most publications will be sent free to anyone requesting it until the supply becones low: Costly publications, more than one copy of a publication, and publications in short supply are subjects for special correspondence. Sucli correspondence should iclentify the writer and explain the use to be made of the publication or publications.

Address orders and correspondence to the Chief,

Illinois Natural History Survey

Natural Resourees Building

607 East Peabody Drive

Champaign, Illinois 61820 